$$
\text { UNIVERSIDADE DE SÃO PAULO }
$$

FACULDADE DE FILOSOFIA, LETRAS E CIÊNCIAS HUMANAS

DEPARTAMENTO DE LETRAS ORIENTAIS

PROGRAMA DE PÓS- GRADUAÇÃO EM ESTUDOS JUDAICOS E ÁRABES

Damián Alejandro Dzienciarsky

\title{
A EXTRAPOSIÇÃO NO HEBRAICO- UM FENÔMENO LINGUÍSTICO DO IDIOMA OU DISCRIMINAÇÃO DOS JUDEUS DA COMUNIDADE ORIENTAL
}

\author{
Versão Corrigida
}

São Paulo

2012 
UNIVERSIDADE DE SÃO PAULO

FACULDADE DE FILOSOFIA, LETRAS E CIÊNCIAS HUMANAS

DEPARTAMENTO DE LETRAS ORIENTAIS

PROGRAMA DE PÓS- GRADUAÇÃO EM ESTUDOS JUDAICOS E ÁRABES

\title{
A EXTRAPOSIÇÃO NO HEBRAICO- UM FENÔMENO LINGUÍSTICO DO IDIOMA OU DISCRIMINAÇÃO DOS JUDEUS DA COMUNIDADE ORIENTAL
}

Versão Corrigida

\author{
DAMIÁN ALEJANDRO DZIENCIARSKY \\ Tese apresentada no Departamento de Pós- \\ Graduação em Língua Hebraica, Literatura e Cultura \\ Judaicas do Departamento de Letras Orientais da \\ Facultade de Filosofia, Letras e Ciências Humanas \\ da Universidade de São Paulo, para obtenção do \\ título de Doutor em Letras.
}

Orientadora: Profesora Dra. Eliana Langer De acordo

\section{São Paulo}

2012 


\section{Agradecimentos}

Gostaria de agradecer a todos os que me ajudaram e apoiaram durante estes anos que trabalhei nesta pesquisa. Um agradecimento especial à minha orientadora, Professora Dra. Eliana Langer, que me orientou ao longo deste extenso caminho.

Agradeço a Eliana a dedicação na leitura, a paciência, as observações e o compromisso que me possibilitaram a realização deste trabalho. Eliana é uma grande profissional e uma amiga que compartilhou comigo a paixão pela língua hebraica e confiou em mim, em minha capacidade de encarar este desafio e completar esta tese de doutorado.

Quero também agradecer a meu amado companheiro de vida, Marcelo Nayar, que sempre acreditou em mim e me acompanhou neste desafio de vida no Brasil. Sem seu apoio e encorajamento, este trabalho não teria sido possível.

A minha querida amiga, Marta Topel, por ter sido um bom ouvido em horas repletas de incertezas e momentos difíceis. Ela me ajudou a adquirir alguns livros essenciais para esta tese. Obrigado pela confiança, pela ajuda na minha vida pessoal e por ser um ser humano genial.

À Capes e à Pró Reitoria as bolsas outorgadas que me permitiram participar de dois congressos em Israel, para adquirir novos conhecimentos que ajudaram na confecção desta pesquisa.

Ao Departamento de Língua Hebraica, Literatura e Cultura Judaicas por me apoiar e escutar quando necessitei.

Agradeço o Professor Dr. Reginaldo Gomes de Araújo e a Professora Dra. Nancy Rozenchan pelas observações valiosas no exame de qualificação.

Devo gratidão ao o Professor Dr. Cyril Aslanov, por ter me orientado e ajudado no esclarecimento dos conceitos linguísticos.

A minha amiga Patricia Barlach por ter me ajudado com o português.

A minha família que aguentou esta distância, às vezes angustiante. Por ter me ouvido sempre e respeitado minhas decisões de vida. Obrigado a minha mãe Susana, meu pai Mauricio, minhas irmãs Alicia e Viviana e meus sobrinhos Julián, Nicolás, Paula e Facundo. Obrigado por tudo e desculpas por não haver podido estar nestes anos com vocês.

E, por fim, agradeço a meus amigos no Brasil e na Argentina. Aos brasileiros, pelo abraço constante, o acolhimento e o apoio durante estes três anos. Aos argentinos por suportar a distância, a saudade e a força que me deram para continuar neste caminho. 


\section{Resumo}

Esta pesquisa versa sobre a análise morfossintática do fenômeno de extraposição no hebraico.

No primeiro capitulo mostro quais são as premissas, as hipóteses e os "corpora" trabalhados nesta pesquisa.

No segundo capítulo, localiza-se a extraposição dentro do sistema morfossintático da língua hebraica revisando o uso da extraposição em diferentes registros do hebraico moderno. Analisei o fenômeno em si, para entender seu uso, formas, regras, nomenclatura e entorno onde a extraposição geralmente aparece.

No terceiro capítulo, analiso o livro "Shum Gamadim ló Yavohu". Por meio desta análise pude pesquisar a linguagem pobre dos personagens, um idioma comum aos bairros da periferia. Os objetivos da analise do livro são, por um lado, confirmar que o fenômeno de extraposição é espontâneo e cotidiano no hebraico, tanto na linguagem oral como na escrita, e por outro lado, analisar por que este fenômeno é considerado como parte do registro baixo na língua hebraica moderna.

No quarto e quinto capítulos, localizei o fenômeno de extraposição no texto bíblico e talmúdico. A Bíblia e o Talmud são as fontes indiscutíveis do judaísmo e constituem o padrão do hebraico para definir o que pertence ou não pertence à língua

hebraica do ponto de vista linguístico. Desta maneira consegui demonstrar que o fenômeno de extraposição é parte da língua hebraica desde a época bíblica.

No sexto e último capítulo, através da analise da extraposição no árabe e no francês, pude demonstrar que a extraposição é um fenômeno frequente nestas línguas, penetrando no hebraico moderno pelos falantes dessas línguas. Entendendo que estes falantes do árabe e francês foram discriminados pelos nativos do hebraico. $\mathrm{O}$ fenômeno de extraposição foi discriminado pelo uso excesivo dos falantes da comunidade judia oriental.

Palavras- chave: Sintaxe do hebraico, Sociolinguística, Extraposição, Fontes do Judaísmo, Discriminação dos judeus da comunidade oriental, Judeus do Magreb. 


\begin{abstract}
The present work deals with the morphosyntactic analysis of the phenomenon of extraposition in Hebrew.

Its first chapter contains the premises, hypotheses and corpora worked on for the research.

Its second chapter identifies extraposition within the morphosyntactic system of the Hebrew language, revising the use/occurrence of "extraposición" in different/distinct registers of Modern Hebrew. The phenomenon in itself is analyzed, with the purpose of understanding the use, forms, rules, nomenclature and environment where extraposition normally occurs.

The third chapter analyzes the book/novel "Shum Gamadim ló Yavohu". It is through this analysis that the language of its characters is researched, which is a simple language, common to the speakers of the suburban neighborhoods. The aims of the analysis of the book are, on the one hand, confirming that the phenomenon of "extraposición" is spontaneous and usual in Hebrew, both in spoken language as well as in writing, and on the other hand discussing why this phenomenon is ascribed to the lower register of Modern Hebrew.

Chapters four and five deal with the identification of the phenomenon of extraposition in Biblical and Talmudic text. The Bible and the Talmud are both undisputable sources of Judaism, and they constitute the pattern of Hebrew in order to define what belongs to Hebrew and what does not from a linguistic perspective. It is thus demonstrated that the phenomenon of extraposition has been a part of the Hebrew language since Biblical times.

In the sixth and final chapter, by means of the analysis of the phenomenon of in Arab and French, it is demonstrated that extraposition is a phenomenon of high frequency of occurrence in those languages. Given the understanding that the Hebrew of native speakers of Arab and French was looked down upon by native speakers of Hebrew, the phenomenon of extraposition was scorned due to its excessive use by the speakers of the Oriental Jewish community.

Key Words: Syntax of Hebrew, Sociolinguistics, Extraposition, Sources of Judaism, Discrimination of Oriental Jews, Jews of the Maghreb.
\end{abstract}


מחקר זה מתעסק בבעיות המורפו-סינטקטיות של התופעה הלשונית הנקראת "חלק ייחוד" בעברית.

בפרק הראשון אני מראה את קדם ההנחות, ההיפותיזות והקורפוסים שאיתם

עבדתי במחקר זה.

בפרק השני ממקמים את חלק הייחוד בתוך המערכת המורפוסנטקטית של הלשון העברית, תוך כדי בדיקה של שימוש חלק הייחוד במשלבים שונים של העברית בת זמננו. ניתחתי את התופעה בפני עצמה כדי להבין את שימושה, צורותיה, חוקותיה וסביבתה הכללית.

בפרק השלישי ניתחתי את הספר "שום גמדים לא יבואו". בעזרתו של ניתוח זה חקרתי את שפתם של דמויות הספר, כשמדובר בשפה מאוד ענייה, שפה משותפת לשכונות הפרברים. המטרות של ניתוח הספר הן להוכיח שתופעת הייחוד היא ספונטנית ויומיומית בעברית, גם בשפה המדוברת כמו בשפה הכתובה, ולנתח מדוע התופעה הזאת שייכת למשלב הנמוך של השפה העברית.

בפרקים ארבע וחמש סומנו דוגמאות הייחוד בטקסט התנכי והתלמודי. התנ"ך והתלמוד הם, ללא כל ספק, מקורות היהדות והם הקובעים מה שייך לדיקדוק העברי ומה לר שייך מבחינה בלשנית. עם הסימון הזה הצלחתי להראות שתופעת הייחוד היא חלק מהדיקדוק העברי מתקופת התנ״ך.

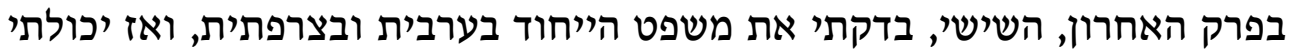
להראות שהייחוד הוא תופעה נפוצה וחוזרת הרבה בשפות הללו, וחדרו ללשון העברית על ידי דוברי הערבית והצרפתית. בהבנה שהדוברים האלה היו מופלים על ידי הדוברים הילידים של העברית, תופעת הייחוד התקבלה כשפה נמוכה בגלל אפליית עדות המזרח. מילות מפתח- תחביר עברי, סוציולינגוויסטיקה, חלק ייחוד, מקורות היהדות, אפליית עדות המזרח, יהודי מאגרב. 


\section{Índice}

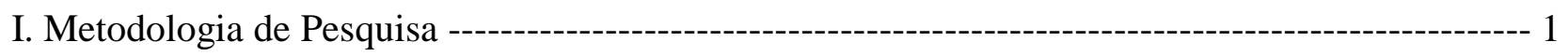

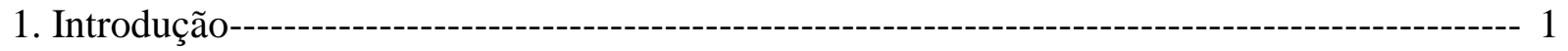

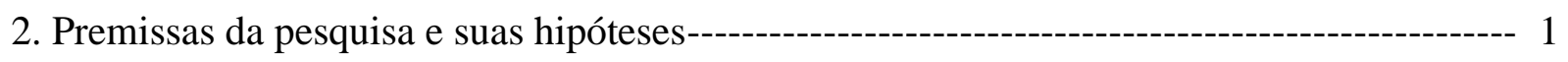

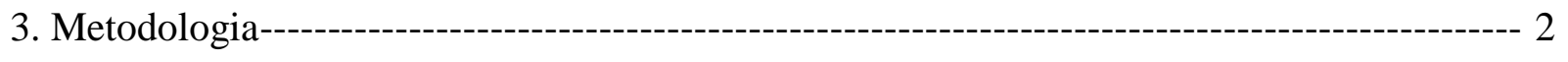

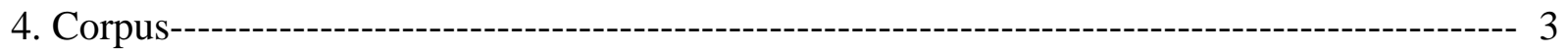

4.1. Corpus primário--------------------------------------------------------------------------------- 3

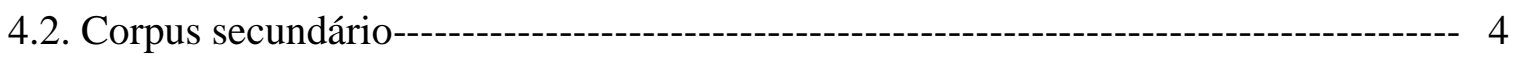

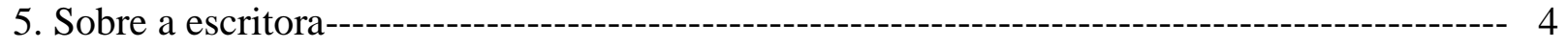

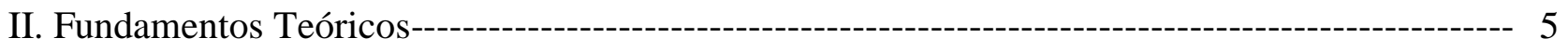

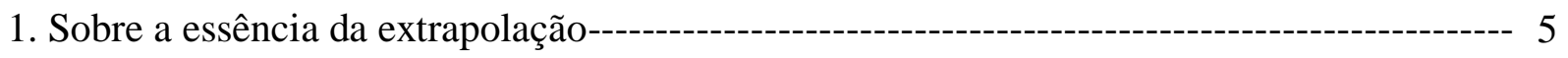

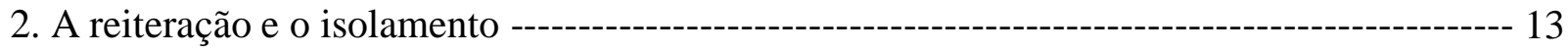

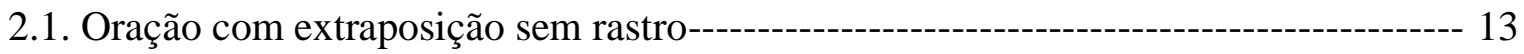

2.2. Orações com a seguinte estrutura: substantivo+ pronome pessoal+ substantivo ou

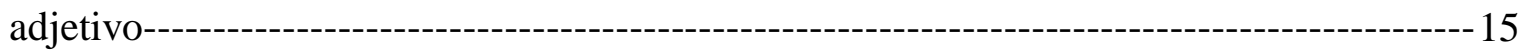

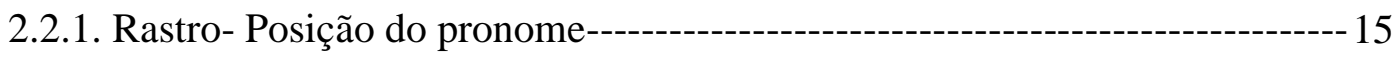

2.2.2. Estruturas nas quais o rastro é o sujeito da oração formal---------------------- 15

2.3. Níveis de extraposição ----------------------------------------------------------------------- 17

2.3.1. O maior nível de extraposição - O conectivo isolado "en cuanto a"--------- 18

2.3.2. Nível alto de extraposição - o rastro na posição de objeto ou modificador 22

2.3.3. Nível médio de extraposição---------------------------------------------------- 23

2.3.4. Nível baixo de extraposição ----------------------------------------------------- 24

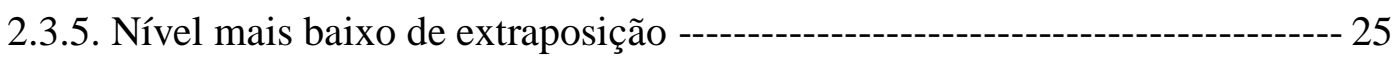

3. Extraposição dianteira ou anterior------------------------------------------------------------------- 25

3.1. A extraposição é um substantivo e o rastro é o sujeito da oração formal--------------- 25

3.1.1. Pronome pessoal como sujeito da oração formal------------------------------- 26

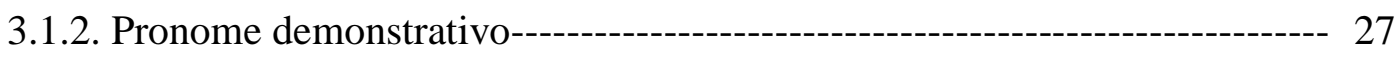

3.1.3. Pronome demonstrativo como predicado da oração formal + pronome

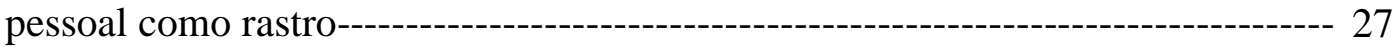


3.2. A extraposição é um substantivo e o pronome demonstrativo é o predicado da oração formal

3.3. A extraposição é um substantivo e o rastro na oração formal é também um substantivo na posição de predicado ou de objeto

3.4. A extraposição é um substantivo e o rastro está na posição de objeto ou circunstancial

3.4.1. Estruturas de existência e propriedade

3.5. A extraposição é um pronome pessoal representado na oração formal pelo mesmo pronome, seja separado ou ligado ao verbo em posição de sujeito-

3.6. A extraposição é um substantivo ou um pronome com seu rastro no modificador direto da oração formal

3.6.1. Um rastro que é modificador direto aparece em orações extrapostas

substantivas e são similares às orações comparativas------------------------------------- 35

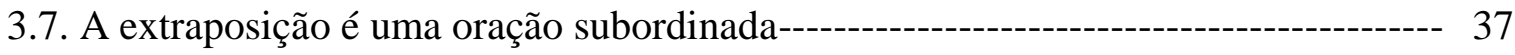

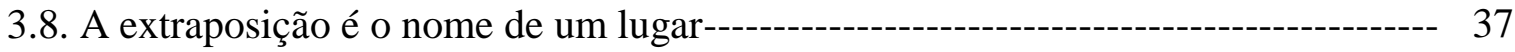

3.9. A extraposição é uma pergunta------------------------------------------------------------- 38

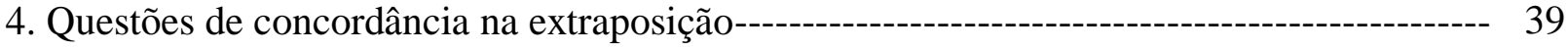

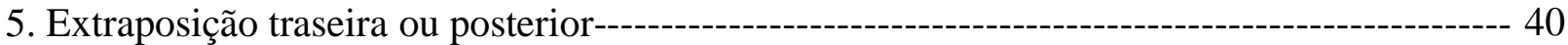

5.1. A extraposição é um substantivo e na oração formal há um elemento que a sinaliza, e sua posição é de sujeito------------------------------------------------------------------------- 42

5.2. A extraposição é um substantivo e na oração formal o rastro é o predicado---------- 42

5.3. A extraposição e o rastro são um substantivo-------------------------------------------- 42

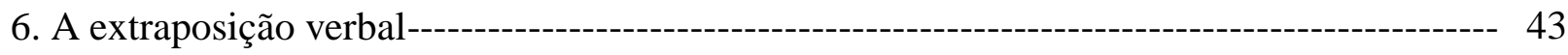

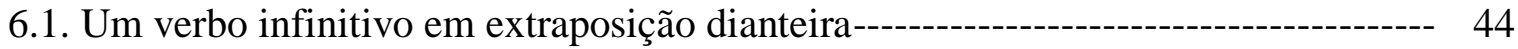

6.1.1. A reiteração no corpo é o verbo conjugado------------------------------------- 44

6.1.2. A reiteração no pronome ---------------------------------------------------------- 45

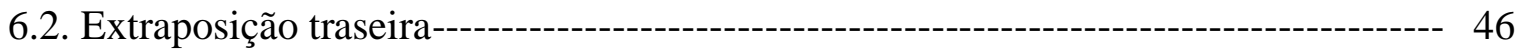

7. Orações de estrutura análoga àquelas com extraposição ---------------------------------------- 47

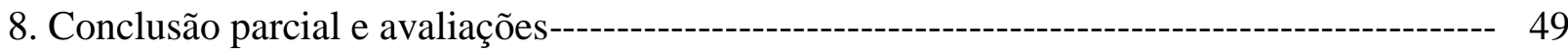


III. Shum Gamadim Ló Yavohu (Nenhum anãozinho virá)------------------------------------------------ 50

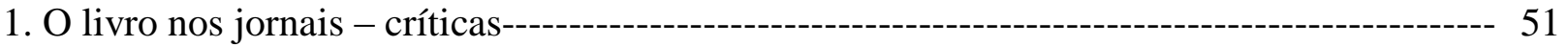

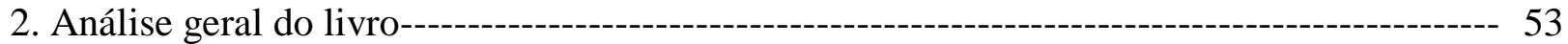

3. Exemplos de extraposição neste livro--------------------------------------------------------------- 56

3.1. Simona Dadón (1 - 37)------------------------------------------------------------------------- 56

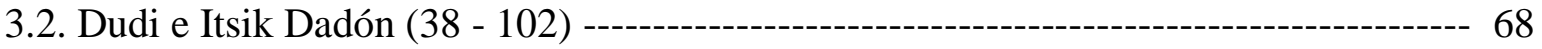

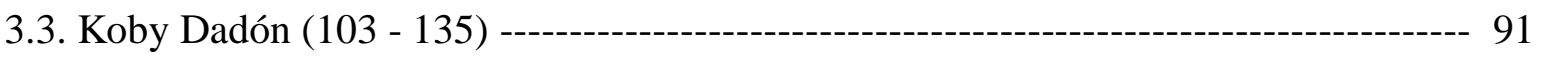

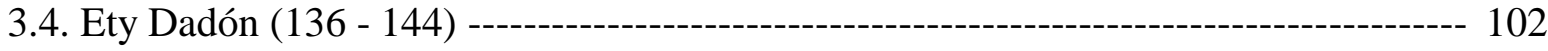

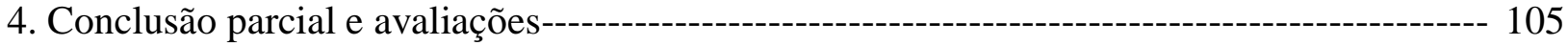

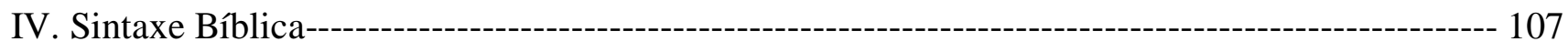

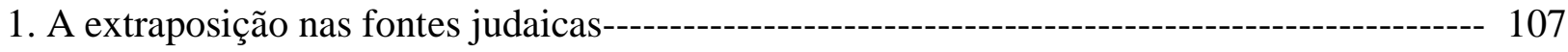

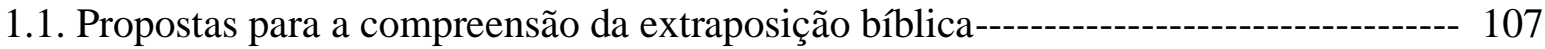

1.2. Exemplos de extraposição segundo a categoria sintática-------------------------------- 109

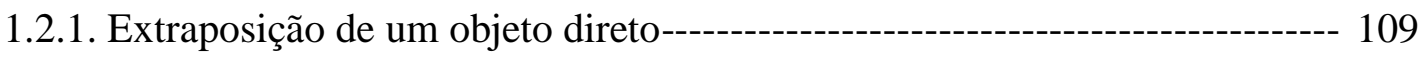

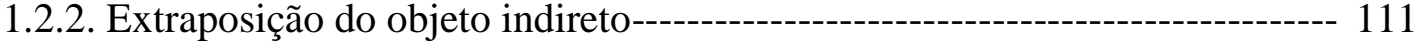

1.2.3. Extraposição do circunstancial de lugar---------------------------------------- 112

1.2.4. Extraposição do predicado--------------------------------------------------------- 112

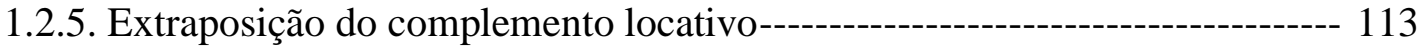

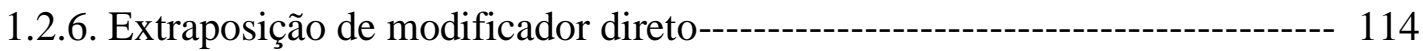

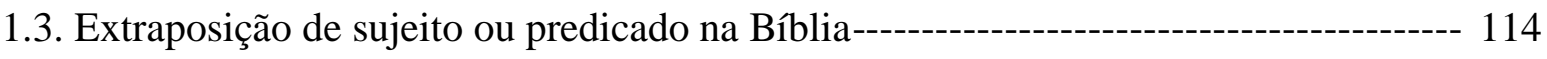

1.4. Classificação da extraposição "sujeito"----------------------------------------------------- 117

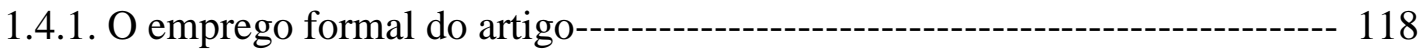

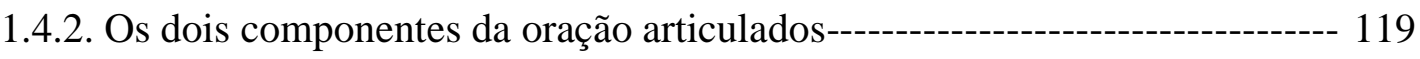

1.5. Os três modelos de análise de Driver-------------------------------------------------------- 121

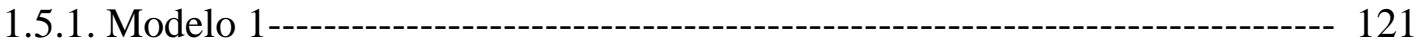

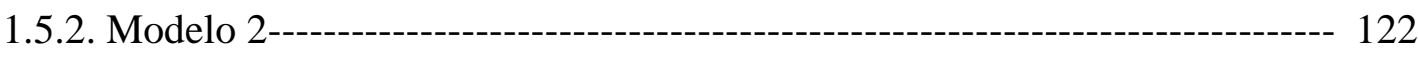

1.5.3. Modelo 3------------------------------------------------------------------------------- 123

2. Casos especiais de extraposição. Estruturas não esperadas--------------------------------------- 125 
2.1. Oração formal começa com a conjunção coordenativa "e"

2.2. A preposição da extraposição se repete na oração formal

2.3. O núcleo da extraposição e o rastro são a mesma palavra

2.4. Oração com mais de um dos casos citados acima-

3. Outros exemplos de extraposição na Bíblia-

4. Conclusão parcial e avaliação

V. Sintaxe Talmúdica-

1. A extraposição na Mishná em termos gerais

2. Extraposição simulada-

2.1. A condição na extraposição simulada-

2.2. O "se" condicional

3. Exemplos de extraposição simples na Mishná-

4. Conclusão parcial e avaliações

VI. Os judeus do norte da África-

2. Árabe e francês magrebiano

3. A extraposição no francês-

4. A extraposição em árabe

4.1. Orações extrapostas que começam com أماًَ - em quanto a...

4.2. Extraposição sujeito

5. O árabe e o hebraico

5.1. As orações verbais

6. Situação dos magrebinos e o hebraico-

7. Deslegitimação da língua utilizada pelos magrebinos

8. Conclusão parcial e avaliações-

9. Conclusões

10. Bibliografia- 


\section{I- Capítulo 1- A pesquisa}

\section{1- Introducão}

Esta pesquisa pretende investigar sobre o fenômeno de extraposição em hebraico, por uma análise profunda do fenômeno, tanto na linguagem oral como na linguagem escrita, tratando de pesquisar o uso desta estrutura sintática como parte do hebraico atual; o registro no qual opera na língua hebraica; por que é percebido como pertencente a tal registro; origem e fenomenologia da extraposição nas fontes hebraicas.

Para isso realizei uma análise descritiva do fenômeno, tanto na literatura hebraica moderna como nas fontes judaicas, a Bíblia e o Talmud. Uma vez levantados os casos, estes foram classificados segundo sua característica estrutural. Logo, uma vez demonstrado que este fenômeno é parte do hebraico, foram dados exemplos do árabe e do francês mostrando a extraposição nestas línguas e sua influência no hebraico.

\section{2- Premissas da pesquisa e suas hipóteses}

- A hipótese primeira e geral desta pesquisa é que o fenômeno de extraposição, muito usado na língua hebraica atual, é parte da gramática hebraica, apesar de a maioria dos falantes a considerarem um fenômeno que não pertence ao hebraico e seu uso aparece somente em um registro baixo do idioma.

- A Bíblia é o padrão e a autoridade para estabelecer quais fenômenos linguísticos são parte da gramática hebraica e quais não são.

- O fenômeno de extraposição é mais utilizado pela população que emprega um registro baixo do idioma.

- O fenômeno de extraposição é menos utilizado pela população que emprega um registo alto do idioma.

- A extraposição é parte do sistema sintático e morfológico da língua hebraica e seu uso é espontâneo.

- Este fenômeno existe na literatura bíblica e talmúdica de maneira natural como qualquer outro fenômeno linguístico. 
- A extraposição surge por uma necessidade do falante de enfatizar um componente da oração.

- A pragmática é uma ferramenta básica para compreender o uso desta estrutura, uma vez que ele pode ser entendido em sua generalidade, analisando o ambiente em que aparece.

- O falante evita utilizar este fenômeno já que ele o considera parte do registro baixo da língua.

- Este fenômeno entra de maneira intensa no hebraico moderno por influência dos falantes do árabe e do francês que chegaram a Israel, vindos do norte da África.

- Considerar a extraposição como parte do registro baixo da língua é uma forma de discriminar o falante, que introduziu este fenômeno no hebraico por influência das suas línguas maternas.

\section{3- Metodologia de pesquisa}

Esta pesquisa versa sobre a análise morfossintática do fenômeno de extraposição no hebraico. Para isso será realizada uma análise descritiva do fenômeno, tanto na literatura hebraica moderna como nas fontes judaicas, a Bíblia e o Talmud. Levantar-se-ão os casos que serão classificados segundo sua característica estrutural. Logo, uma vez demonstrado que este fenômeno é parte do hebraico, serão dados exemplos do árabe e do francês mostrando a extraposição nestas línguas e sua influência no hebraico.

Para a análise terei de basear-me nas teorias linguísticas universais para assim logo trasladá-las para o hebraico $\mathrm{s}$ fim de que sejam aplicadas. No último capítulo, onde se vê a influência dos falantes do norte da África sobre o hebraico, serão abordadas teorias sociolinguísticas, já que a análise enfoca os falantes e sua influência no entorno.

É importante deixar claro que os exemplos serão escritos em espanhol, já que é a minha língua materna e estudei de forma muito profunda sua gramática. Desta maneira poderei fazer analises comparativas muito mais evidentes. 


\section{4- O Corpus}

\subsection{Corpus primário}

Serão estudadas três obras principais como corpus central desta pesquisa. São estas a Bíblia, o Talmud e um livro intitulado "Shum gamadim lo iavohu"

da escritora Sara Shiló, publicado pela primeira vez no ano de 2005. Este livro, a primeira obra de Shiló, relata uma história que acontece em uma cidade sem nome, ainda que os indícios e descrições façam crer tratar-se de Kiryat Shmoná ou de Maalot, sendo esta última a mais provável, pois Shiló viveu muitos anos nesta cidade. Durante a história, o leitor vai conhecendo o medo que os habitantes tinham das bombas e dos atentados terroristas, quais eram os métodos para sua defesa e como decidiram viver em uma atmosfera deprimente e hermética.

Esta história é contada pela família Dadón, Simona e seus filhos. Shiló escreve em uma linguagem muito pobre, em um idioma comum aos bairros da periferia. Apesar de escrever na linguagem natural dessas pessoas, a autora consegue dar voz própria a cada um dos personagens, criando um idioma que caracteriza cada membro da família.

A linguagem cotidiana da família não é "padrão", não é "literária", atraindo a atenção do leitor e conduzindo-o ao longo do relato.

Toda a história transcorre nas mentes dos membros da família Dadón, na noite em que caem foguetes Katyusha na cidade. O livro trabalha a atitude e os sentimentos de cada um dos protagonistas nesta noite, mas a eles se combinam velhas recordações e os desejos de cada um de ter um futuro mais digno. O que atrai o coração do leitor é a linguagem através da escrita. É um livro que demonstra como uma língua tão baixa pode obter sentimentos e sensações tão fortes.

Este livro recebeu muitas críticas. Muito escritores disseram que, para traduzilo a outros idiomas, primeiro teria de ser traduzido para o hebraico. Entretanto, "Shum gamadim lo iavohu" obteve muitos prêmios e se tornou um dos livros mais vendidos em Israel.

Esta obra literária ensina-nos como se pode fazer arte "sublime" utilizando material "de baixo nível". Com isso quero dizer que este livro é um claro exemplo de como uma linguagem simples deu origem a uma obra tão rica em termos literários. 
Ele narra os problemas econômicos, sociais e anímicos da família Dadón, através de um hebraico vernáculo, relatado pelas vozes dos protagonistas, em una língua que não é literária e que às vezes chega a emocionar o leitor tanto como emociona conhecer o destino desta família.

O mais interessante é que os protagonistas não percebem que falam um hebraico "pobre". Para eles esta é sua língua falada e a das pessoas que vivem no entorno.

\subsection{Corpus secundário}

Os exemplos para explicar o fenômeno de extraposição serão trazidos da literatura israelense e de reportagens feitas em diferentes meios de comunicação. Da literatura israelense, serão escolhidos autores famosos como Grossman, Oz e Shalev (detalhados na bibliografia). Como exemplos da imprensa escrita serão utilizados os jornais Iediot Hacharonot e Haaretz. Os exemplos de linguagem oral serão recolhidos de entrevistas cedidas para a televisão, assim como diálogos fluidos e espontâneos dentro da sociedade israelense.

\section{5- Sobre a escritora Sara Shiló}

Sara Shiló (sobrenome de solteira, Bavli) nasceu em Jerusalém em 1958. Em 1976 chega à cidade de Mahalot onde constitui família com seu marido Avner. Sara dedicou-se ativamente à educação e ao ensino, escrevendo contos para crianças e fazendo apresentações de seus contos por meio de teatro de fantoches. Por muitos anos ela dirigiu um centro de artes.

Depois de 15 anos, a família de Shiló se muda para Kfar Vradim, onde vive até os dias de hoje.

"Shum gamadim lo iavohu" é seu primeiro livro para adultos. Com ele, Shiló ganhou o prêmio Isaac Wiener de obra literária original e o prêmio de literatura do Ministério da Educação. No ano de 2006, recebeu o prêmio Sapir que se outorga à revelação literária, por ser este seu primeiro livro. 


\section{Capítulo 2- Fundamentos teóricos}

\section{1- Sobre a essência da extraposição}

A extraposição ${ }^{1}$, estrutura sintática muito comum em diversas línguas, consiste em trasladar um componente de uma oração, colocando-o geralmente na posição sintática de sujeito da mesma. Ao extrapor esta parte, fica uma marca, um rastro $^{2}$ na oração principal, mostrando que neste espaço sintático há outro componente. A relação entre a marca e o elemento extraposto é anafórica ${ }^{3}$.

Esta oração ficará composta, então, de uma parte extraposta e seus complementos, caso os tenha, e uma oração matriz com um rastro que faz referência à parte extraída ${ }^{4}$. Em geral o componente extraído se coloca no começo da oração ${ }^{5}$ e o rastro, resultante de sua posição anterior concordará em gênero e número com a parte extraposta.

Exemplo:

- Compré flores para Ruti.

קניתי פרחים לרותי

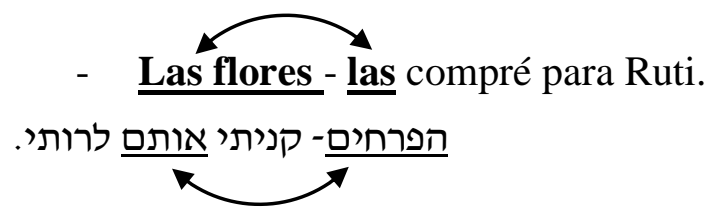

Como produto desta extraposição obtén-se uma parte chamada "extraposta" e outra a que chamarei "oração original ou matriz", na qual se observa geralmente o rastro antes mencionado ${ }^{6}$. Alguns autores, como Tali Bar ou Noga Ilani ${ }^{7}$, argumentam

\footnotetext{
${ }^{1}$ Em português, os conceitos anacoluto e pleonasmo são categorias dentro do fenômeno extraposição aqui pesquisado..Ver Terra, Pág. 435.

2 Quando este rastro se refere à marca deixada pelo objeto, seja direto ou indireto, chamar-se-á clítico correferencial. Este termo se usa na análise sintática de muitos idiomas, principalmente no espanhol. No hebraico o uso do pronome clitico é diferente, já que este idioma não admite a coaparição de um clítico e um sintagma complemento direto ou indireto. Ver Porto Dapena Págs. 35-36.

${ }^{3}$ Um vínculo anafórico é aquele estabelecido entre dois ou mais elementos de uma oração, em que um desses elementos se relaciona com o outro que o antecede. Este recurso pode ser usado para enfatizar o primeiro elemento e evitar a redundância. Quase todas as línguas usam este recurso linguístico, principalmente para referir-se a um componente da oração anteriormente mencionado.

${ }^{4}$ Ver Goldenberg, Tautological Infinitive, Pág. 37.

${ }_{6}^{5}$ Em uma porcentagem mínima podemos encontrar o elemento extraposto no final da oração.

${ }^{6}$ Há casos em que o rastro não está concretizado foneticamente, mas pode ser inferido de acordo com o contexto.
} 
que a extraposição é o sujeito da oração e a oração matriz seria o predicado. Como esta pesquisa tem como objetivo avaliar a veracidade deste fenômeno em hebraico e não a de discutir sua nomenclatura prefiro referir-me à extraposição como tal ou como sujeito psicológico e ao restante como oração matriz. Por outro lado, não estou de acordo em chamar a extraposição de sujeito, já que nas línguas com concordância desinencial entre verbo e sujeito, como o hebraico, se reconhece o sujeito como o núcleo do sintagma nominal, que geralmente concorda em número e, em geral, também em gênero, com o núcleo do sintagma verbal ou nominal predicativo. $\mathrm{O}$ elemento extraposto poucas vezes concorda em gênero e número com o verbo, portanto prefiro não chamar o elemento extraposto de sujeito.

A pergunta de por que se forma esta estrutura extraposta é muito discutida na literatura linguística geral, e a nomenclatura que se utiliza para falar dela reflete os vínculos que esta estrutura tem com o componente afastado da oração de origem. No caso do hebraico, este fenômeno é chamado "Ichud", da raiz I.CH.D, que denota especialidade, unicidade e que faz referência à característica especial desta categoria. Entre os fenômenos morfossintáticos podemos dizer que a extraposição é especial por excelência.

Na nomenclatura estrangeira, os nomes para este fenômeno estão relacionados com o fato de possuir uma estrutura anômala à de uma oração simples, ou ao fato de trasladar um componente para posicioná-lo no lugar do sujeito. "Casus Pendens" (nomenclatura utilizada por Driver ${ }^{8}$ ), ou caso independente, que se detém por si só, expressa a ideia que, depois de transformar uma oração simples em uma extraposta, a parte extraída (o que Driver chama de sujeito) fica isolada, sem um predicado ao qual se vincule. O uso da nomenclatura "Extraposition" (termo que estabeleceu Jespersen ${ }^{9}$ ) reflete o significado estrutural deste fenômeno em relação a qualquer oração "simples", já que a estrutura extraposta altera a oração simples por colocar um

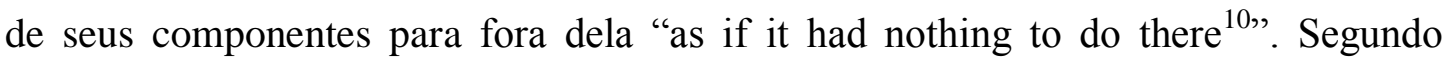
Jespersen o termo "extraposition" assinala não só a colocação de um componente no

\footnotetext{
${ }^{7}$ Ver Bar, Pág. 298 e Ilani, Pág. 22.

${ }^{8}$ Ver Driver, Págs. 264- 274.

${ }^{9}$ Ver Bussmann, capítulo “extraposition”, Pág. 160b.

${ }^{10}$ Ver Jespersen, Analytic Syntax, Pág. 35.
} 
princípio da oração, senão também no fim, "after thought ${ }^{11 ",}$ quer dizer uma palavra ou palavras que foram colocadas, uma vez finalizada a oração matriz. A dicotomia em falar de sujeito e predicado para nomear o sujeito e predicado gramatical ou o sujeito e predicado "conceptual" ou comunicativo (que foram definidos sujeito e predicado lógicos ou psicológicos ${ }^{12}$ e posteriormente theme e rheme segundo os linguistas da escola de Praga, o topic e comment) foi levada em conta por parte dos linguistas, ao investigar a extraposição. Esta dicotomia foi a que gerou a utilização da topicalization $^{13}$ como um conceito geral para assinalar a transferência de uma parte da oração que não é o sujeito, na posição de sujeito, no começo da oração, com o objetivo de enfatizar. Tenho de destacar que não em todos os casos de topicalização se utilizarão ferramentas pronominais (ou outras) para proporcionar uma expressão apositiva $^{14}$ no corpo da oração que co-refira com a parte extraída. Quer dizer, nem toda topicalização exige a transformação de uma oração simples em uma extraposta. Em outras palavras, podemos dizer que a estrutura extraposta é um caso particular de topicalização da língua.

A maior parte dos enunciados que produzimos nas conversas é formada por um tema ${ }^{15}$, que indica aquilo de que trata o enunciado, e um rema, o que se diz a propósito do tema:

$\frac{\text { Sujeito }}{\frac{\text { El perro }}{\text { Tema }}} \frac{\text { Predicado }}{\frac{\text { tiene hambre }}{\text { Rema }}}$

Neste caso, o tema coincide com o sujeito e o rema com o predicado. Esta distribuição sintática dos constituintes maiores do enunciado não é arbitrária mas um

\footnotetext{
${ }^{11}$ Ver Jespersen, A Modern English Grammar, Pág. 357.

${ }^{12}$ Ver Jespersen, The Philosophy of Grammar, Pág. 145 em diante. Jespersen revisa o uso dos termos "sujeito lógico", "sujeito psicológico" e mostra a confusão existente. Ele propõe utilizar termos como subject, predicate. Ver también Elffers- van Ketel, Els, The historiography of grammatical concepts : 19th and 20th-century changes in the subject-predicate conception and the problem of their historical reconstruction, Amsterdam e Atlanta, 1991, Pág. 156.

${ }^{13}$ Ver Bussmann, capítulo "topicalization", Pág. 488a; ver também David Crystal, Encyclopedic Dictionary of Language \& Languages, Oxford 1992, Pág. 156.

${ }^{14}$ Expressão apositiva. Entende-se por aquela expressão cuja função é referir-se a um componente mencionado antes.

$15 \mathrm{O}$ uso destes termos, pela primera vez, foi de C. F. Hockett; ver Lyons, Pág. 335. Estes termos, Theme e Rheme (o Tema e Rema) fazem referência à dicotomia entre o tema, que é a parte geral do que se fala e da que se supõe um conhecimento prévio por parte dos interlocutores, e o rema que é o que se diz do tema trazendo informação nova.
} 
reflexo da distribuição da informação. O sujeito, sendo geralmente aquele de quem se fala, costuma coincidir com o tema e, por isso, o falante o situa no início do enunciado: o objeto, em troca, tende a apresentar-se na parte remática, quer dizer, na parte direita do enunciado. Contudo, nem todos os enunciados a respeitam, já que podemos encontrar enunciados que alteram esta ordem e introduzem, por exemplo, elementos como o objeto indireto na parte inicial do enunciado, que em condições normais deveria ter sido ocupada pelo sujeito. O emissor outorga uma organização hierárquica aos distintos elementos do enunciado que, dependendo do lugar que estes ocupem dentro da estrutura, terão um papel fundamental no significado da mensagem. Obviamente, a parte temática goza de uma condição privilegiada com respeito à remática, já que a informação mais importante do enunciado reside nela. Contudo, o que permite que haja dinamismo comunicativo é o rema, posto que, sem a predicação que se faz a propósito de algo ou alguém, dificilmente se daria a comunicação. Alguns idiomas, como o hebraico, possuem meios linguísticos para evidenciar e exaltar o tema em um enunciado. Um destes meios é a extraposição ou deslocamento, que consiste na troca de um componente do enunciado de uma posição para outra.

$\mathrm{Na}$ literatura generativa, transformacional, é muito comum o uso do termo deslocamento (right left) ${ }^{16}$ para assinalar a extraposição tanto para o começo como para o final da oração. A definição deste fenômeno por meio destes conceitos não se distancia muito do uso da extraposição de Jespersen, já que expressa uma relação estrutural muito clara e estabelece que o membro extraposto, para o começo ou para o final da oração, está localizado em uma posição na qual não se encontraria caso se tratasse de uma oração normal. A literatura linguística geral e a hebraica, tampouco apresentam uniformidade ao usar os conceitos "sujeito" e "predicado" para referir-se ao sujeito extraposto, e encontraremos termos como "sujeito (ou predicado) lógico ou psicológico", "sujeito natural" ou "sujeito explícito". A partir de agora, para mencionar o membro extraposto, referer-me-ei ao "sujeito psicológico" ou à extraposição em si, e o restante será a oração formal ou matriz.

\footnotetext{
${ }^{16}$ Segundo Bussmann, no capítulo "Left vs. Right dislocation", Pág. 272a, estes conceitos foram apresentados por J. R. Ross, mas o mesmo Ross (em seu livro "Infinitive Syntax!", New Jersey 1986, Pág. 253) relaciona o conceito de Left dislocation a Maurice Grosse.
} 
Segundo a pragmática, quando se definem o sujeito e o predicado, o sujeito seria o que o falante conhece e o predicado se adiciona ao sujeito como algo novo ${ }^{17}$. Analisar orações extrapostas e ouvi-las, mostra-nos claramente que estas estão divididas em duas partes: uma primeira parte, o sujeito extraposto ou psicológico, e outra parte que corresponde à oração matriz localizada a seu lado, que corresponderia sintaticamente a um predicado psicológico ${ }^{18}$. Na linguagem coloquial, percebe-se uma pausa entre a parte extraposta e a oração matriz. Na linguagem escrita, esta divisão é marcada pelos signos de pontuação.

Quando se ouvem orações onde o componente extraposto se coloca antes da oração matriz, em um discurso fluido, não planejado, em uma conversa ou entrevista, não poucas vezes, tem-se a sensação de que o falante começou a falar de um tema determinado, mudou de ideia e começa a falar de outro assunto, mas este mantém um vínculo com o primeiro. A relação entre os assuntos fica estabelecida pela marca que faz referência ao primeiro tema, ainda que ela não esteja concretizada foneticamente e se infira do contexto. Na linguagem escrita e cuidada, o uso de orações com extraposição é mais planificado e menos natural.

Como a extraposição é em sua maioria substantiva, espera-se que o membro a ser extraposto seja de estrutura substantiva também, com o mesmo sujeito, o objeto direto, indireto ou o modificador direto. Em porcentagens gerais, a extraposição mais encontrada é a dos objetos (direto ou indireto), seguida pelo sujeito, o modificador direto e, raras vezes, um circunstancial ${ }^{19}$ ou um verbo.

Na seguinte oração:

- La policía- a ella no le interesa el asunto del tren (Grossman, Pág. 74).

- המשטרה- היא בטח לא אוהבת את עניין של הרכבת. (גרוסמן, עמ' 74)

\footnotetext{
${ }^{17}$ Ver Jespersen, The Philosophy of Grammar, Pág. 145.

${ }^{18}$ Outro enfoque propõe Tzdaka "Hamishpat" (Pág. 226) marcando que a divisão das orações com extraposição consta de duas partes, um sujeito temático e um predicado temático, e este último sempre inclui em si um rastro que remete ao sujeito temático. Só que para ele, esta divisão é boa quando a oração é retirada de seu contexto.

19 Um circunstancial é o termo utilizado em espanhol para o adjunto adverbial.
} 
A extraposição "Policía" (משטרה) está representada com a marca do pronome pessoal "ella" (היא), isto é, o sujeito da oração matriz. Em comparação com isto, na oração:

Y estos drogadictos, aléjate de ellos. (Oz, Al Taguidi, Pág. 49)

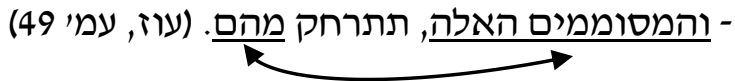

a extraposição está representada pela marca na frase preposicional "de ellos" (מהם). Mostrarei exemplos com os diferentes componentes, que podem ser extraídos.

Vou começar exemplificando com orações extraídas dos diferentes meios de comunicação, sejam orais ou escritos.

\section{Objeto direto:}

- Este Chaim Shtauber, una pena que no to hayas encontrado.. (Grossman, Pág. 44)

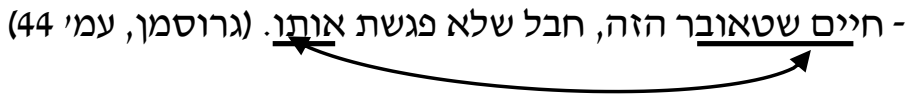

Um sujeito:

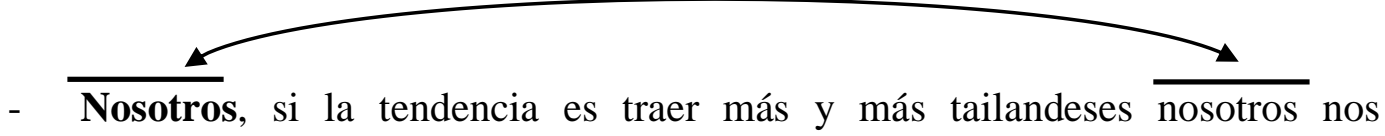
quedaremos sin animales. (Un entrevistado en la televisión, 14 de noviembre 2004)

- אנחנו- אם המגמה תהיה להביא עוד ועוד תאילנדים אנחנו נישאר בלי חיות. (ראיון בטלויזיה,

14 בנובמבר 2004)

Um verbo:

- Agarrar yo no lo agarro de nadie y robar yo no robo, pero celar yo celo. (Shalev, Keyamim Achadim, Pág. 30). -לקחת אני לא לוקח מאף אחד ולגנוב אני לא גונב, אבל לקנות אני מקנא. 
No caso em que o elemento que se extrapõe aparece com uma preposição, geralmente esta não acompanhará o elemento extraposto até o começo da oração, ainda que possamos encontrar alguns exemplos nos quais, antes da extraposição, aparece também a preposição.

- El menú yo lo compuse. (Entrevistado en la televisión, octubre 1994)

- את התפריט אני הרכבתי אותו. (מרואיין בטלוויזיה, אוקטובר 1994)

Neste caso, a preposição acompanha o elemento extraposto.

A extraposição pode ser uma palavra, uma combinação de duas palavras ou mais, ou uma oração subordinada, como:

- En lo que se refiere a mi mente, ya hace tiempo decidiste que soy una total estúpida. (Oz, Kufsá, Pág. 11).

-מה שנוגע לשכל שלי, הלא אתה כבר מזמן הסכמת עם עצמך סופית שאני מטומטמת לגמרי.

Nesta oração, a marca está localizada no final da oração.

Também a extraposição pode subordinar outra oração completa. Exemplo:

- Un hombre que pasó tres guerras y recibió perfil 21 por una crisis temporal o causas familiares, y su registro de conducir le fue negado, su situación es más difícil que la de ellos. (“Tguvot”, Haaretz, 12 de agosto de 2004).

-אדם שעבר שלוש מלחמות וקיבל פרופיל 21 בגלל משבר זמני או נסיבות משפחתיות, ונשלל ממנו

רשיון נהיגה- מצבו קשה משלהם.

A oração que acompanha o componente isolado pode ser composta ${ }^{20}$ ou simples, substantiva ou verbal.

Podemos ver o caso em que um membro se coloca depois da oração matriz, nestes exemplos:

${ }^{20}$ Uma Oração Composta se refere, em português, ao Período Composto. 
- Cómo ellos se atreven, estos ärabes? (Shif- Ya'ari, Pág. 141)

- איך הם מעיזים, הערבים הלל!?

- $\quad$ Eso está en su sangre, el espionaje. (Grossman, Pág. 78).

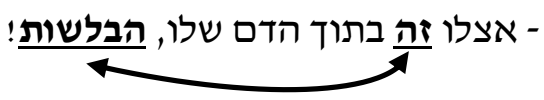

Não se poderia analisar este fenômeno em uma língua viva de um ponto de vista estático mas, de qualquer maneira, dá a impressão de que a extraposição no começo é mais comum que a extraposição no fim, tanto na sua expressão oral como na escrita.

A extraposição em hebraico é um tema pesquisado por muitos estudiosos. Gesenius ${ }^{21}$, Brafman $^{22}$ e Driver ${ }^{23}$ veem estes tipos de orações como compostas. Também Blau exibe uma postura similar, baseada na diferenciação de um "sujeito psicológico" e um "sujeito gramatical" 24 , estabelecendo que o uso de orações extrapostas, onde o sujeito psicológico não é um substantivo e o predicado psicológico não é um verbo, gera uma tensão no falante em que o isolamento de um componente é um dos mecanismos para diminuir a dita tensão.

Segundo Blau, na seguinte oração,

- $\quad$ Los ojos del sabio (están) en su cabeza.

- עיני החכם בראשו.

\footnotetext{
${ }^{21}$ Ver Gesenius, Págs. 450, 457.

22 Ver Brafman, Pág. 181. Segundo Brafman, as orações com extraposição são orações compostas, onde a extraposição é o "sujeito natural e isolado" e o resto será o "predicado natural". Ele também considera que esta estrutura são orações de origem e sua origem está nas orações interrogativas.

${ }^{23}$ Ver Driver, Pág. 265. Ele mantém que o uso da extraposição é a forma mais fácil para evitar entorpecer a oração. Com respeito às vantagens, ele diz que, isolando um componente no começo da oração, se simplifica a estrutura sintática do corpo da oração. Driver também argumenta que o membro que se isola será o sujeito da oração e o resto seu predicado.

${ }^{24}$ Ver Blau, Pág. 70.
} 
o sujeito psicológico não é "Los ojos del sabio", já que o sujeito psicológico será a informação conhecida, neste caso "el sabio". O predicado, que corresponde à informação desconhecida, seria "los ojos (están) en su cabeza" (העיניים בראש).

Segundo os enfoques de Ornán e Goldenberg (ver especialmente Goldenberg, “Tautological Infinitive”), a oração com extraposição é uma oração composta, onde o componente isolado será o sujeito e o restante seu predicado. O que a diferencia de outras orações compostas é que, neste caso, o predicado não estará subordinado ao sujeito extraído.

\section{2- A reiteração e o isolamento}

\subsection{Orações com extraposição sem rastros na oração matriz}

Para que a extraposição exista, devem cumprir-se as seguintes condições: isolamento de um componente na posição de sujeito psicológico e a reiteração deste componente na oração matriz (rastro). Segundo o enfoque mais reconhecido, a reiteração da extraposição na oração predicativa é morfológica ${ }^{25}$.

O rastro pode ser um pronome pessoal ou demonstrativo. Segundo o material que coletei, a presença deste rastro é um elemento fundamental na estrutura extraposicional, mas não é condição que esta esteja representada em um componente morfológico na oração matriz; é possível que o rastro não esteja de maneira explícita $^{26} \mathrm{e}$, de toda forma, não se discute sua existência na oração. Na sintaxe são de grande importância também os componentes que não se mencionam na oração. A pergunta seria se estes componentes estão presentes de outra forma, sendo estes construídos pragmaticamente, ainda que não tenham presença fonética. Baseando-me nos resultados, poderia afirmar que a reiteração na oração matriz está fundamentada na extraposição, mas não sempre há reiteração morfológica.

\footnotetext{
${ }^{25}$ Ver Azar "Tachbir", Pág. 106, denomina as orações em que a extraposição não deixa rastro, "extraposição simulada". A extraposição simulada é similar à comum, só que sem elemento morfológico que faça referência.

${ }^{26}$ Comparar com Goldenberg, "Tautological Infinitive”, Pág. 37.
} 
Nas seguintes orações podemos ver que o membro isolado, isto é, o sujeito psicológico, o elemento extraposto, aparecerá na oração matriz pelo contexto, sem rastro ou presença fonética.

1- Los estudios sagrados, yo en general no estoy interesado ${ }^{27}$. (Oz, Kufsá Schorá, Pág. 100).

- הלימודי קודש אני בכלל לא מעוניין.

Quando se extrapõe um objeto direto, é característica a repetição do objeto extraposto em forma de pronome; sem esta recuperação pronominal, o enunciado não seria aceitável na linguagem escrita. Neste caso específico, quer-se mostrar como fala este personagem.

2 - Aproximadamente sesenta por ciento de lo que escribiste estoy de acuerdo. - בארך שישים אחוז ממה שכתבתה אני די מסכים.

Como observamos nestas orações, a reiteração nem sempre deve ser morfológica ${ }^{28}$, e daqui se infere que o rastro não é uma condição obrigatória para definir uma oração extraposta.

O isolamento, que aparece por de elementos morfológicos, prosódicos ou com signos de pontuação, é uma condição para a extraposição, mas deve-se assinalar que nem todo isolamento indica uma extraposição. Em algumas expressões, de estilo definido, podemos encontrar orações como:

- $\quad$ Lo encontré. Ayer.

- פגשתי אותו. אתמול.

Neste caso, o membro isolado não está extraposto. De um ponto de vista sintático, é possível isolar um componente da oração sempre que haja na mesma oração outro elemento que se refira a ele (ainda que às vezes esta referência seja contextual e não

\footnotetext{
${ }^{27}$ Segundo o contexto, se entende que o falante não está interessado "neles", referindo-se aos estudos sagrados.

${ }^{28}$ Ornán (Pág. 104- 105) menciona o possível desaparecimento do rastro morfológico.
} 
esteja concretizada foneticamente). Desta maneira, podemos dizer que, estruturalmente, qualquer oração verbal em hebraico tem a capacidade de extrapor um de seus elementos ${ }^{29}$. As orações substantivas também terão está capacidade, sempre que haja algum elemento que se refira ao sujeito ${ }^{30}$.

\subsection{Orações com a seguinte estrutura: substantivo+ pronome pessoal+ substantivo}

\section{ou adjetivo}

2.2.1 Os linguistas discordam sobre a questão da posição do pronome nestes tipos de estruturas. Driver e Goldenberg ${ }^{31}$ (Hapoal) veem o pronome como o rastro do elemento extraposto, localizado na posição de sujeito. Rubinstein, Azar e Ornán ${ }^{32}$ o veem-no como o rastro ou como a ligação, e Rozen afirma que se trata somente de uma ligação ${ }^{33}$. Segundo Rozen, a ligação pode aparecer no princípio ou no final da oração:

Él es bueno- el helado - היא טובה- הגלידה

El helado- es bueno él - הגלידה- טובה היא

Rubinstein manifesta suas dúvidas com relação aos pronomes neste tipo de orações, já que é claro para ele que, em termos de estrutura, é uma oração extraposta. A solução por ele oferecida é entender o pronome (neste caso como ligação) como parte da oração formal, dizendo que este pronome aparece entre os dois componentes de uma oração substantiva para marcar o vínculo predicativo entre estes componentes ${ }^{34}$. Para Rubinstein a diferença entre uma oração substantiva, onde o pronome pessoal é considerado como a extraposição, e outra oração onde o pronome será o sujeito da

\footnotetext{
${ }^{29}$ Ver Goldenberg, Hapoal, Pág. 319.

${ }^{30}$ Estaríamos falando de uma relação apositiva, onde estes dois elementos assinalam o mesmo objeto.

${ }^{31}$ Ver Goldenberg, Hapoal, Pág. 298.

32 Rubinstein, pág. 116 e págs. 183- 198. Em sua consideração sobre este tipo de estruturas, ele concorda com aqueles que dizem que orações como "Mi tía (es) médica" (Dodati hi rofá- דודתי היא ex extraposição por parte de sua estrutura, mas o pronome será ligação e não o sujeito da oração formal ou matriz, já que se refere a "médica" e não a "mi tía".

${ }^{33}$ Rozen, págs. 242- 247. Rozen estabelece que em orações do tipo "El vino (es) barato aqui" (Yain

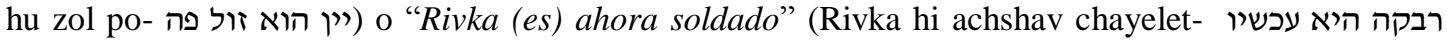
חילת) o pronome é uma ligação.

${ }^{34}$ Ver Rubinstein, Pág. 116.
} 
oração matriz, vai depender do tipo de isolamento do sujeito, isto é, quando será enfatizado em termos pragmáticos ou discursivos.

\subsubsection{Estruturas nas quais o rastro é o sujeito da oração formal}

A- Orações nas quais o predicado da oração formal é um adjetivo, como por exemplo: Los anteojos ellos (están) rotos - Hamishkafaim hem shvurim-

B- Orações nas quais o predicado da oração formal é uma frase preposicional, como por exemplo:

El libro (está) sobre la mesa - Ha Sefer hu al hashulchan- הספר הוא על השולחנ

C- Orações de identidade igualitária ${ }^{35}$, onde o primeiro membro possua um artigo definido, por exemplo:

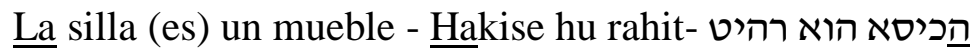

D- Orações de identidade igualitária, onde nenhum dos dois membros está acompanhado pelo artigo ${ }^{36}$, por exemplo:

(Una) silla (es un) mueble - Kise hu rahit- כיסא הוא רהיט

E- Orações de identidade igualitária, onde os dois membros estão acompanhados por artigos, por exemplo:

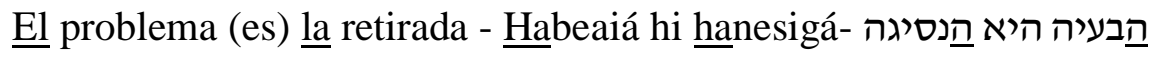

F- Orações de identidade igualitária, onde o segundo membro possui um artigo definido, por exemplo:

Vino (es) la bebida - Yain hu hamashké- "ין הוא המשקה

\footnotetext{
${ }^{35}$ Estes tipos de orações são chamadas também comparativas, já que o primeiro e segundo membros marcam ao mesmo objeto. $\mathrm{O}$ segundo membro é uma aposição ao primeiro.

${ }^{36}$ Em hebraico, o artigo indefinido não se concreta foneticamente, isto é, o fato de não se colocar nada antes do substantivo pode ser, de acordo com o contexto, que o substantivo esteja articulado indefinidamente.
} 
O exemplo da estrutura F carece de uma mensagem clara. Somente superlativamos o membro com artigo, dando a entender que estamos falando $d a$ bebida dentre todas as bebidas.

Nas estruturas de A até E o pronome poderia ser colocado ao final da oração, obtendo-se uma frase metafórica ou de um registro elevado. Na estrutura A pode-se eliminar o pronome pessoal e obter-se-á uma oração padrão (Hamishkafaim shvurim(המשקפים שבורים). Isso se deve ao fato de que o predicado é um derivado de um verbo e, portanto, o valor predicativo é indiscutível. Também nas orações de estrutura B pode-se omitir o pronome, mas entre os membros geralmente há um guia que os divide. Analisando as estruturas C, D e E podemos ver que há uma diferença entre a estrutura C comparada com as D e E, ainda que se trate de orações comparativas (de identidade igualitária). Na estrutura $\mathrm{C}$ o valor predicativo é claro, inclusive omitindo o pronome, e isto se deve ao fato de os membros serem diferentes: um com artigo e o outro não. Nas orações de estruturas D e E a situação é diferente: Nestes casos a inclusão do pronome é inevitável, já que os membros comparados têm o mesmo valor semântico (com artigos ou não) e, portanto, nenhum dos mesmos está enfatizado. Por isso é necessário incluir o pronome, para tornar efetivo o valor predicativo, gerando um espaço entre os componentes.

\section{$\underline{2.3 \text { Niveis de extraposição }}$}

A expressividade de uma oração vem do nível de isolamento do sujeito, tanto em

orações cuja oração formal é verbal como em orações substantivas ${ }^{37}$. Com relação a isso há cinco níveis: no nível mais alto de extraposição encontramos aquelas orações que se iniciam com o conectivo isolado "en cuanto a" (באשר ל-) . Há que ver este conetivo como a estrutura que expressa o isolamento do sujeito psicológico em seu nível máximo.

No nível mais baixo de extraposição encontram-se aquelas orações nas quais a ordem das palavras é diferente do esperado, não há rastro que se refira ao elemento extraposto e reconhecemo-las como orações extrapostas somente pelo isolamento de um componente que funciona como sujeito psicológico.

\footnotetext{
${ }^{37}$ Ver Bar, Pág. 303.
} 


\subsubsection{O maior nível de extraposição - O conectivo isolado "en cuanto a" (באשר ל-).}

Este conectivo é uma estrutura fixa, sendo abreviação de uma frase como "el asunto del que te quiero hablar en cuanto a él" (הדבר שאני רוצה לומר באשר לו), o "si nos expresamos en cuanto a" (אם נתבטא באשר ל-). Nas orações que começam com este conectivo, a extraposição fica completamente isolada da oração formal. Neste tipo de orações, a parte extraposta funciona como uma introdução ao tema, restando the emotividade, isto é, o conteúdo destas orações enfatiza o sujeito psicológico como todas as orações com extraposição, só que neste caso não transmite nenhuma mensagem emocional. Talvez por isso, estes tipos de orações geralmente aparecem em textos escritos e, muito raramente, em uma fala espontânea. Exemplos:

1- En cuanto al resto de los compañeros, no estoy seguro cuánto ellos representan al público libre. (Or Kashti, Haaretz, 12 de octubre 2004, cita). - באשר לשאר החברים, אני לא בטוח עד כמה הם מייצגים את הציבור החופשי.

2- En cuanto a la creencia palestina, yo también estoy segura que ellos deben cambiarla. (Shulamit Aloni en la Televisión, 7 de diciembre 2004).

\section{- אשר לאמנה הפלסטינית, אני גם סבורה שהם צריכים לשנות אותה.}

A ligação "en cuanto $a$ "- e outras similares a ela foram discutidas especialmente na literatura científica. Segundo Guiora ${ }^{38}$, a expressão "en cuanto $a$ " - assinala, entre outras coisas, o Tema (Theme) ${ }^{39}$ da oração. O mesmo acontece com a oração extraposta. $\mathrm{Azar}^{40}$ escreve no capítulo sobre a extraposição que a seguinte oração

Y al pueblo pásenlo para las ciudades (Génesis 47, 21)

ואת העם תעבירו אותו לערים (בראשית מז כא)

\footnotetext{
${ }^{38}$ Ver Guiora, Pág. 266.

${ }^{39}$ Ver nota de rodapé 15.

${ }^{40}$ Ver Azar "Shetach", Pág. 81.
} 
seria similar à oração do tipo:

Y en cuanto al pueblo pásenlo para las ciudades - ובאשר לעם תעבירו אותו לערים

A parte que inicia a oração (y en cuanto al pueblo) apresenta um elemento que vincula o dito anteriormente com o que se quer dizer agora, mas este não é um elemento aglutinante puro, mas é considerado também como um elemento do qual se diz algo, isto é, ele seria também um sujeito superficial psicológico. Tzdaka ${ }^{41}$ cita que, às vezes, se anexam à extraposição estruturas que mostram explicitamente que se está falando de uma extraposição, como por exemplo "en cuanto a"-, "en relação a"-, "acerca de"-, "con respecto a"-, "con referencia a"-, "hablando de". Segundo ele, estas estruturas são restos de uma oração completa cujas partes foram anuladas ("quiero decirte algo [...]", "en cuanto a-"), e um exemplo seu: "Y en cuanto a los inocentes y a los hipócritas hay que cuidarse de ellos".

Como já foi mencionado, a conjunção "en cuanto $a$ "- e as similares são um enlace que gera o vínculo com o que se mencionou antes e, portanto, antecedem a extraposição. Nos próximos exemplos, o vínculo é, principalmente, de oposição:

1- Lo principal fue hecho, yo mismo con mis ojos vi cómo la obra va a la imprenta, $\mathbf{y}$ en cuanto a Tomas Astor- ya marqué con él una reunión después del mediodía. (Shachar, Pág. 42).

- העיקר נעשה, אני במו עיניי ראיתי איך יורד המחזה לדפוס, ואשר לתומס אסטור - הלא כבר קבעתי אתו פגישה להיום אחר הצחריים. (שחר, עמ' 42).

A extraposição "en cuanto a Tomas Astor" se relaciona por um vínculo de oposição ao que se mencionou antes: "Lo principal fue hecho [...] y en cuanto a Tomas Astor", isto é, Tomas Astor, em contraposição ao principal, que é a impressão da obra, é um assunto secundário, e é muito simples ocupar-se dele. E assim os seguintes exemplos:

${ }^{41}$ Ver Tzdaka “Tachbir”, Págs. 210-211, 209. 
2- Toda la santidad será "la visión humana" - y en cuanto a la existencia sobre la tierra, la subsistencia- esa será su última preocupación. (Ahí, Pág. 20). - כולו קודש יהיה ל"חזון האדם" - ואשר לקיום עלי אדמות, לפרנסה - תהא זו דאגתו האחרונה.

3- Podría dedicar todo su tiempo a la "visión humana" sin molestarse. $\underline{\text { Y en lo que se }}$ refiere a las horas de comida y cambio de pañales y cosas como esas- incluso éstas no deberían distraer sus ideas y pensamientos de lo principal. (Ahí, Pág. 23)

- יוכל להקדיש את כל עתותיו ל"חזון האדם" באין מפריע. ומה שנוגע לשעות ההאכלה ולהחלפת החיתולים וכיוצא בהם-- אפילו אלה אינם צריכים להסיח את דעתו והגיגיו מן העיקר.

A extraposição, nos exemplos 2 e 3, ocupa-se de assuntos materiais da existência sobre a terra (exemplo 2) e do tratamento de um bebê: horários de comida e troca de fraldas (exemplo 3), e estes assuntos são opostos em significado ou contradizem a oração anterior e, obviamente, são secundários em comparação à obra (da oração 1), que é o principal. Nestas orações trata-se de mostrar contraposição entre o espiritual e o material, entre o principal e o secundário pelo uso da extraposição, utilizando a conjunção "en cuanto a" (exemplos 1 e 2) e "en lo que se refiere a" (exemplo 3) que se antepõem à extraposição.

Segundo Margulin ${ }^{42}$, além da função textual da extraposição, que modifica o tema do discurso, podemos observar outras funções: expressar uma oposição em termos semânticos e sinalizar um contexto dos temas tratados no discurso. A determinação de um contexto referente aos temas tratados na oração gera uma coerência e, desta maneira, adota-se uma estratégia com o objetivo de cumprir as regras discursivas, isto é, a estrutura extraposicional leva à coerência do texto.

Como a extraposição, também o marcador discursivo "en cuanto a" marca o sujeito de debate na oração. Segundo Margulin ${ }^{43}$, a função textual de uma oração com "en cuanto $a$ " na literatura hebraica de nossos dias, cria uma referência no discurso pela troca de tema. Portanto, segundo seu ponto de vista, aquele que escreve a literatura hebraica atual não usa o marcador "en cuanto $a$ " como um organizador do discurso.

\footnotetext{
${ }^{42}$ Ver Margulin, Págs. 113- 116.

${ }^{43}$ Ver Margulin, Pág. 138.
} 
$\mathrm{Na}$ verdade, é possível comprovar que este marcador é muito pouco utilizado. Quero deixar claro que Margulin analisa também orações com "en cuanto a" sem que essas orações tenham sido extrapostas. No entanto, refiro-me somente às orações com "en cuanto a" com extraposição.

Trarei mais dois exemplos.

4- En cuanto a la reproducción de los humanos en el mundo- esto es realmente increible... (Ahí, Pág. 28).

- ובאשר להתרבותם של בני אדם בעולם- הרי זה באמת פלא...

A extraposição no exemplo 4 ("Y en cuanto a la supervivencia humana y su final") devolve o debate ao tema da explosão demográfica, em contraposição à explosão do protagonista por tanta preocupação com sua filha, da que se fala no parágrafo anterior. A progressão seria: começa com a explosão demográfica, desvia-se até a explosão do protagonista e, com a extraposição e o marcador "en cuanto a", retoma o primeiro tema discutido. Cito aqui o contexto onde aparece esta frase:

[...] e com toda a energia e, apesar da vibrante preocupação que se vai aprofundando já sem rumo, surgiam nele constantemente pensamentos do tipo amplo e geral, algumas perguntas filosóficas, como questões relacionadas com o conceito "explosão demográfica", que era muito comum e aceitável, naqueles dias em que os sociólogos [...] já lhe parecia que dentro de um momento estouraria de preocupação, mas não por isso exatamente se refere à expressão "Quanto a reprodução dos humanos no mundo" - é realmente incrível: é tão difícil trazer um filho ao mundo, criá-lo e protegê-lo de todos os perigos possíveis [...] e, apesar disso, milhões de hindus se somam à humanidade a cada ano. (Ahí, Pág. 28)

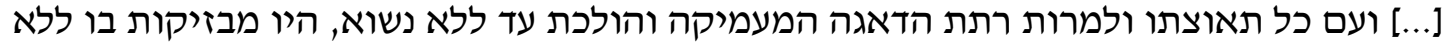

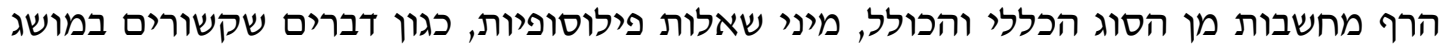

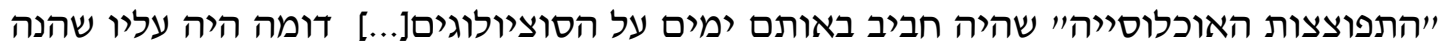
עוד מעט קט תתפוצץ מדאגה, אבל הרי לא לכך, בדיוק, מתכוון הביטוי, ובאשר להתרבותם של 
בני אדם בעולם - הרי זה באמת פלא: כל כך קשה להביא לעולם הזה ילד אחד ולגדל אותו

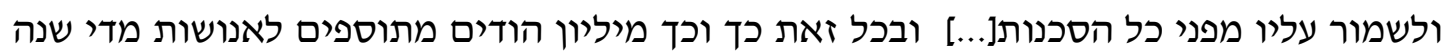

Neste exemplo o tema é a maravilha da reprodução humana. No exemplo 5 o protagonista passa para outro tema, a morte.

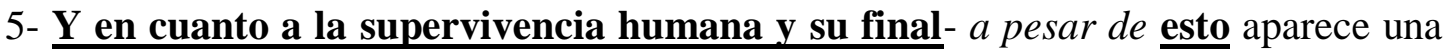
gran paradoja... (Ahí. Pág. 28).

- ואשר לעצם הקיום האנושי וחדלונו- אף בכב נעוץ פרדוכס גדול...

Este é o contexto no qual aparece esta oração:

[...]Y en cuanto a la supervivencia humana y su final - "enquanto isso" aparece um grande paradoxo sem precedente: tomemos, por exemplo, o grande gênio da humanidade, Albert Einstein - qualquer pesquisador estúpido e carente de personalidade pode, por meio de um golpe de faca ou pressionando o gatilho, acabar com sua vida [...] sendo este um tema amplo como nenhum outro que esta complexa entidade [...] será altamente danificada e fácil de transformar-se em nada. (Ahí, Pág. 28)

[...] ואשר לעצם הקיום האנושי וחדלונו- אף בכך נעוץ פרדוכס גדול מאין כמוהו : ניקח, למשל,

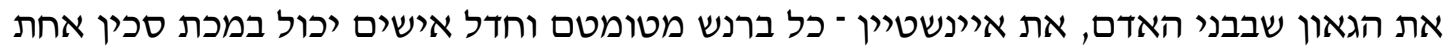
או בלחיצה על ההדק לשים קץ לחייו...] והרי תמה גדול הוא מאין כמותו שהישות המורכבת הזאת[...] תהיה עד כדי כך פגיעה ומהירה להפוך לאין ולאפס.

Neste caso, podemos notar bem que o marcador "en cuanto a esto" traz uma ênfase muito forte ao rastro, que aparece automaticamente em sua continuação.

\subsubsection{Nivel alto de extraposição- $O$ rastro na posição de objeto ou modificador}

Um nível muito alto de extraposição terão as orações cujo sujeito psicológico tem um rastro na oração formal, e este rastro está na posição de objeto direto ou modificador 
direto, sendo a divisão entre o sujeito psicológico e a oração formal bem marcada. Não obstante, não possuem uma marcação especial de isolamento, como fica evidente nas orações que começam com "en cuanto a". Exemplos:

1- Familia- tú sabes, no tengo idea cómo se come eso. (Oz, Kufsá, Pág. 148).

- משפחה- את יודעת, אין לי מושג איך אוכלים את זה.

2- ...y tu madre ya tuvo ella suficiente dolor de tu parte. (Oz, Kufsá, Pág. 161).

- .... - ואמב כבר היה לה מספיק תוגה ממך.

3- Ese Chaim Shtauber, qué pena que no lo encontré. (Grossman, Pág. 44).

- חיים שטאובר הזה, חבל שלא פגשת אותו.

\subsubsection{Nível médio de extraposição-Rastro na forma de pronome na terceira pessoa}

Um nível menor de extraposição terão as orações, onde a reiteração na oração formal estará representada por um pronome pessoal na terceira pessoa do singular na posição de sujeito da oração formal; nestas orações percebe-se que a ênfase da extraposição diminuiu. Estas orações aparecem nas seguintes estruturas: substantivo- pronomesubstantivo/ adjetivo/ frase pronominal, ou na estrutura substantivo- pronome - verbo. Alguns exemplos:

1- Esa familiaridad de los personajes, ella es lo sublime de la música de Guefen. (Yael Dar, Haaretz, 23 de noviembre de 2004).

- הפמיליאריות הזאת של הדמויות, היא גולת הכותרת של שירתו של גפן.

2- El Partido Político Laboral él quedará en el gobierno. (Senador Eli Dayan en la radio, 6 de enero 1995$)$.

- מפלגת העבודה היא תישאר בשילטון.

3- El viejo Manfred puede ser que él esté un poco podrido. (Oz, Kufsá, Pág. 176).

- מאנפרד הזקן ייתכן שהוא קצת רקוב. 
2.3.4 Nível baixo de extraposição - sujeito psicológico é um pronome pessoal e a reiteração só é observável na morfologia verbal.

Nestas orações, a extraposição é geralmente o pronome pessoal na primeira pessoa $e u$, e o rastro se observa no verbo, já que o sujeito da oração formal é um sujeito oculto. Exemplos:

1- Yo , que hasta hace un momento era un viajante común en el tren, fui humillado de repente... (Grossman, Pág. 59)

- אני, שלפני רגע רק הייתי נוסע רגיל ברכבת, נשפלתי פתאום...

2- $\underline{\text { Yo }}$ en todos estos años no quise estar cerca de los israelíes y principalmente me alejé de las mujeres de Tel Aviv. (Oz, Al Tagidi, Pág. 113)

- אני הן כל השנים האלה לא רציתי בקרבת ישראלים ובייחוד התרחקתי מן הנשים התל אביביות.

3- $\underline{\text { Yo}}$ ? Desde primer grado no dibujé. (Amalia Argaman, Yediot Hacharonot, 16 de diciembre 1994, título de un artigo).

- אני? מכיתה א׳ לא ציירתי.

4- Yo a tu madre la extrañé también viva y también muerta (Shalev, Pág. 60) - אני לאמא שלך התגעגעתי גם בחייה וגם במותיה.

Nesta estrutura de oração, o sujeito da oração formal é marcado pela conjugação verbal. $O$ isolamento se percebe na ordem das palavras na oração, quando um circunstancial ou um objeto separa o pronome pessoal do verbo da oração formal.

No primeiro exemplo, fica separado o pronome pessoal do verbo por uma oração subordinada adjetiva; no segundo, a partícula Hen enfatiza mais o isolamento; no terceiro é provável que a pergunta e a antecedência do circunstancial gerem e enfatizem o isolamento. No quarto exemplo, o isolamento é produto da intervenção do objeto entre o pronome e o verbo. 
O fato de o pronome ser $E u$ faz com que o nível de expressividade destas orações seja elevado e assim também a divisão entre a extraposição e a oração formal.

\subsubsection{Nível mais baixo de extraposição - Falta de rastro}

Estas orações são aquelas nas quais não há reiteração morfológica da extraposição, e só há seu isolamento, isto é, o posicionamento do componente no começo da oração determina que seja uma oração extraposta.

Dos exemplos antes citados no tópico 2.1, vou citar dois exemplos: o 1 e o 2 .

Se o exemplo 1 começasse com "en los estudios sagrados" (בלימודי קודש), a análise teria sido como a de uma oração simples que começa com um objeto direto. $\mathrm{O}$ fato de colocar no início "los estudios sagrados" (הלימודי קודש) serve para mostrar a ênfase e isolamento, e por isso há de se analisar esta oração como uma oração extraposta difícil de encontrar. No exemplo 2 a falta da preposição con antes de "sessenta por cento" (שישים אחוז) é o que estabelece a posição da frase na extraposição.

\section{3- Extraposicão dianteira ou anterior}

\subsection{A extraposição é um substantivo e o rastro é o sujeito da oração formal}

$\mathrm{Na}$ maioria das orações cuja extraposição é um substantivo e o rastro na oração formal é um pronome pessoal ou um pronome demonstrativo, a oração formal é substantiva e seu conteúdo semântico é declarativo ou descritivo. Sua distribuição é muito ampla tanto na língua escrita como na oral. O uso de um pronome pessoal como rastro, na posição de sujeito da oração formal, é muito comum e podemos encontrá-lo também em orações comparativas assim como naquelas onde o predicado é um adjetivo ou uma frase preposicional. Nas orações nas quais o predicado da oração formal é um adjetivo ou uma frase preposicional, o rastro será geralmente o pronome pessoal ele/ ela (היאו הוא) e não o pronome demonstrativo este/a (זאתוזה). Na maioria dos casos "este", em orações comparativas, é um elemento anafórico que se refere a uma situação geral e não específica, estabelecendo neutralidade. Em muitas orações deste tipo, o valor de expressividade foi-se desgastando até que não as percebamos como orações extrapostas, no que se refere a seu conteúdo emocional. 
Apesar do que foi dito antes, as seguintes orações se consideram como extrapostas gramaticalmente. Exemplos:

\subsection{1- Pronome pessoal como sujeito da oração formal}

1- Una situación, en la que la sociedad entrega a sus hijos e hijas con mucho trabajo, a quien está dispuesto a ocuparse de esto, ella es una situación irregular. (Haaretz, 12 de agosto 2004, cita del informe Shenhar sobre educación) ${ }^{44}$

- מצב, שבו חברה מוסרת את בניה ובנותיה בקבלנות למי שמוכן לעסוק בכך, הוא מצב לא תקין.

2- El disparo del Primer Ministro en el sistema de justicia, él es peligroso. (Shulamit Aloni en la televisión, 7 de diciembre 2004).

- ההשתלחות של ראש הממשלה במערכת המשפט היא מסוכנת.

3- La sociedad de clase media- baja, ella está abandonada. (El Diputado Shlomo Benizari en la radio, 14 de noviembre 2004).

- החברה מהמעמד הבינוני ומטה היא מקופחת.

Nestas orações, cujas mensagens são declarativas, o uso do pronome antes do substantivo/adjetivo, predicado da oração formal, faz com que o começo da oração seja extrapositivo; na oração 1 pode-se ver o pronome él (הוא) como uma ligação talvez pelo fato de que a mesma palavra, situación (מצב), apareça nos dois lados da comparação.

4- Fuera de esto el dinero, si en efecto habrá dinero, él no es tuyo Noa. (Oz, Al Taguidi, Pág. 86).

- חוץ מזה הכסף, אם אמנם יהיה כסף, הוא לא שלך נועה.

No último exemplo, o número 4, a frase si en efecto habrá dinero cria o isolamento do sujeito psicológico e, portanto, faz-se necessário colocar o pronome pessoal depois da frase, posicionando-se como sujeito da oração formal.

\footnotetext{
${ }^{44}$ Neste caso o pronome é ella ya que concorda em gênero e número com a palavra situación. Em hebraico a palavra é masculina e, portanto, o rastro será él.
} 


\subsection{2- Pronome demonstrativo}

1- Y tú desde tu concepción piensas que la fuerza- ésta es para pegar. (Oz, Kufsá, Pág. 48).

- ואתה באיוולתך חושב שכוח- זה בשביל להרביץ.

2- Suiza! Otra vez Suiza! Esto los pone nerviosos, no es así? (Efraim Kishon en la radio, 14 de octubre 1994, citado en Haaretz el 29 de diciembre 2004).

- שוויצ! שוב שויץ! זה מרגיז אתכם, נכון?

$\mathrm{Na}$ oração 1 pode-se substituir esta (זה) por ela $(\pi)^{45}$. Na oração 2 esta troca é inviável. Isto se deve ao fato de que o pronome demonstrativo mostra, no hebraico moderno, uma neutralidade e uma referência a algo que não foi definido. Se fosse: ella los pone nerviosos estaria referindo-se à Suíça e neste caso não é o que se quer expressar, já que o que os deixa nervosos é a situação (o escritor viveu muitos anos na Suíça e não em Israel e o fato de não haver vivido em Israel os deixa nervosos).

\subsection{3- Pronome demonstrativo (como predicado da oração formal) + Pronome pessoal (como o rastro)}

3- Política, representación diplomática, organizaciones judías- estas son las áreas de trabajo adecuadas para ex campeones. (Tguvot, Haaretz, 12 de agosto 2004). - פוליטיקה, ייצוג דיפלומטי, ארגונים יהודיים- אלה הם תחומי העבודה שהולמים אלופים

4- La asociación hostil en el triángulo jordano- israelí- palestino- esto es el objetivo central del escritor de este libro. (Melman, fin de la introducción).

- השותפות העוינת במשולש הירדני-ישראלי-פלסטיני- זהו מרכז כוונתו של מחבר ספר זה.

\footnotetext{
45 Não há concordância em gênero entre os idiomas.

${ }^{46}$ Neste caso o pronome demonstrativo e o pessoal estão anexados em uma só palavra. Este fenômeno é permitido e é muito comum em hebraico. (זה+הוא= זהו)
} 
Nas orações 3 e 4 aparecem o pronome demonstrativo e o pessoal um ao lado do outro e nesta ordem. A presença do pronome demonstrativo em primeiro lugar na oração formal é o que nos demonstra que o membro enfatizado é o mesmo pronome demonstrativo, e o pronome pessoal será o rastro. Isto é, as áreas de trabalho são estas e não outras; o objetivo central é este e não outro. Estes tipos de exemplos aparecem bastante no hebraico dos sábios ${ }^{47}$.

\subsection{A extraposição é um substantivo e o pronome demonstrativo é o predicado da oração formal}

Estas orações estão formadas segundo a estrutura extraposição - predicado - sujeito, e o pronome demonstrativo é o predicado da oração formal coindexando com a extraposição e com o sujeito da oração formal. Exemplos:

1- El oscurecimiento de los sentidos- éste fue el proceso, que la mayoría de soldados que sirvieron en los territorio pasaron estos meses. (Shif- Iahari, Pág. 150). - התקהות חושים- זה היה התהליך, שמרבית החיילים ששירתו בשטחים עברו בחודשים אלה.

2- Café con helado, esto es lo que quiero ahora. (Oz, Al Tagidi, Pág. 106).

- קפה עם גלידה, זה מה שאני רוצה עכשיו.

3- Conversaciones sobre impuesto de renta y empleados municipales, esto es precisamente lo que necesitábamos. (Linor, Pág. 46).

- שיחות על מס הכנסה ופקידי עירייה, זה בדיוק מה שהיינו צריכים.

\subsection{A extraposição é um substantivo e o rastro na oração formal é também um substantivo na posição de predicado ou de objeto.}

A representação mais "pura" da extraposição na oração formal é a reiteração tautológica sobre a mesma palavra extraposta, ou a colocação de um substantivo qualquer e não o uso do rastro como expressão pronominal do sujeito psicológico,

${ }^{47}$ Ver exemplos em Bendavid, Pág. 741. 
porque um substantivo é um marcador mais específico do pronome pessoal ${ }^{48}$. Exemplos:

1- Ese Somo, se puede pensar que tu vertiginosa mujer, después de revisar personalmente cada quinto hombre en Jerusalem, eligió al final a Gregory Peck. (Oz, Kufsá, Pág. 24).

- הסומו הזה, אפשר היה לחשוב שאישתך המסחררת, אחרי שבדקה אישית כל גבר חמישי רחי בירושלים, בחרה לה בסוף את גרגורי פק.

O uso de um substantivo como representante do sujeito psicológico nesta oração enfatiza, gera conflito e transmite ironia. O nome Gregory Peck é o que representa a Ese Somo; somente o nome de uma pessoa que simbolize uma grande diferença com Somo pode mostrar o desprezo e a ironia que o escritor tentou expressar. É por isso que não havia a opção de expressar o sujeito psicológico com qualquer rastro, senão pelo nome adequado para este caso.

2- Tu hijo $\underline{\text { Boaz}}$, como sabes por las cartas de su madre, ya varias veces pasó que el muchacho se descarriló. (Oz, Kufsá, Pág. 53).

- הבן שלך בועז, כידוע לך מתוך מכתבי אמו, כבר כמה פעמים קרה שהבחור ירד קצת מהמסילה.

3- Y el chico- cómo lograste traer al chico, Felix? (Grosman, Pág. 163).

- והילד- איך הצלחת להביא את הילד, פליקס?

A reiteração por um substantivo, não o mesmo da extraposição, no exemplo 2, e a reiteração tautológica, no exemplo 3, no lugar de ter um pronome demonstrativo como rastro pode dever-se a questões relacionadas com a ênfase ou não. Por não haver signos de entonação para sinalizar a parte da oração enfatizada, é difícil saber a que se referiu o escritor. De qualquer maneira, a representação do rastro por um substantivo e não por um pronome demonstrativo, não é o mais utilizado para a representação da extraposição no rastro.

${ }^{48}$ Sobre a diferença entre o predicado nominal e o predicado pronominal ver Goldenberg, "La oração Siria", Pás. 104- 106. 


\subsection{A extraposição é um substantivo e o rastro está na posição de objeto (ou circunstancial).}

Os casos mais frequentes de orações com extraposição são as orações nas quais a extraposição é um substantivo, e o rastro na oração formal está na posição de objeto (o rastro na posição adverbial não é comum). Estas podem ser de caráter descritivo ou declarativo. Exemplos:

1- El chico? Se te permite llevarlo así? (Grossman, Pág. 163).

- הילד? מותר לך לקחת אותו ככה?

2- Pero amor, que sepas, Sheinfeld, hay que cambiarla por migajas... (Salev, Pág. 307)

- אבל אהבה, שתדע לך, שינפלד, צריך לפרוט אותה לגרושים...

3- ...y ese mismo examen ellos lo aprobaron. (Shulamit Aloni en televisión, 7 de octubre 2004).

- -...... - -

4- El menú yo lo ensamblé. (Entrevistado en la televisión, 24 de octubre 2004).

- את התפריט אני הרכבתי אותו.

Nestas orações, o rastro é um objeto. Somente na seguinte oração:

Vamos a encontrarnos en Kapulsky de Ramat Hasharon, donde nos encontramos con Beni. Kapulsky? habrá allí mucha gente (Linor, Pág. 285)

בואי ניפגש בקפולסקי ברמת השרון, איפה שנפגשנו עם בני. קפולסקי? יהו שם המון אנשים.

A extraposição é um circunstancial e, pelo visto, não é casualidade que eu não tenha encontrado, nos textos que revisei, orações cuja extraposição seja um circunstancial e seu rastro também o seja, já que o circunstancial é enunciado sobre o predicativo, podendo às vezes funcionar como um predicado em orações como: 
El libro sobre la mesa (הספר על השולחן). Por isso, sua essência é de predicado. Do contrario, a oração extraposta enfatiza a função do sujeito cuja posição é substantiva, e, portanto, é factível que um componente de natureza predicativa não apareça, em geral, nesta posição ${ }^{49}$.

\subsubsection{Estruturas de existência e propriedade}

Há/ não há (iesh/ein- ישואין) + complemento, expressão da existência e propriedade em hebraico ${ }^{50}$ nas seguintes estruturas: "há X" (Há um cão - יש כלב); "há + complemento X” (Há água na garrafa- יש בבקבוק מים); “complemento + há X” (Na garrafa há água- בבקבוק יש מים); “há X + complemento" (Há água na garrafa- יש ( מים בבקבוק ( מים

Outra estrutura que marca a existência e propriedade em hebraico é " $\mathrm{X}$ há + complemento Y”, que é a estrutura de extraposição (A garrafa, há nela água- הבקבוק, יש בו מים o complemento "be-/le-“" com o pronome enclítico ligado a eles será o rastro do membro extraposto. Exemplos:

1- Y yo, tengo yo un grado de satisfacción parcial. (Oz, Kufsá, Pág 161).

- ואילו אבני, יש לי מידה של סיפוק חלקי.

2- Porque una mujer embarazada, ella tiene sus locuras y hay que considerarla. (Shalev, Pág 289)

- כי אישה בהריון יש לה שגעונות וצריך להתחשב.

\footnotetext{
${ }^{49}$ Sobre este assunto escreve Ora Schwartzwald. Ela cita: "en los complementos del verbo sobresalen los siguientes fenómenos: con algunas preposiciones como 'be'(ב) , 'al'(על ) , 'lifnei' , acharei' (אחרי), utilizadas como circunstanciales de lugar en oraciones extrapuestas, la huella será el enclítico adherido a ellas, ya sea que la extraposición posea un componente [+ vivo] o que no lo tenga; en otras preposiciones como 'el'(אל) , 'min') , utilizadas como circunstancial de lugar, la huella será 'ahí' ( שם- (sham) cuando la extraposición carece del componente [+ vivo]. De cualquier forma, raramente se encuentre una extraposición de circunstancial que no sea locativo y que no tenga el componente [+ vivo]." (Schwartzwald, Pág. 335). Entre os exemplos que traz:

- La cajonera, Dan la puso sobre los estantes- המגירה, דן שם בה את המדפים

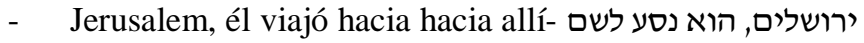

- Esa noche, nos sentamos entonces hasta tarde- הלילה הוא, ישבנו אז עד מאוחרים

Mais exemplos se podem encontrar IBIDEM. A fonte destas orações não foi citada e em todas as orações expostas a extraposição é um substantivo e a preposição que indica a adverbialidade foi anulada.

${ }^{50}$ Ver a discussão sobre estas estruturas em hebraico em Rozen, Pág. 214; Glinert, Págs. 178-181; em sírio - Goldenberg, La oração Siria, Pág. 117.
} 


\subsection{A extraposição é um pronome pessoal representado na oração formal pelo mesmo pronome, seja separado ou ligado ao verbo em posição de sujeito.}

Não todos concordam que uma oração como "Yo? Desde primer grado no pinté." (אני? מכיתה א׳ לא ציירתי) seja uma oração extraposta ${ }^{51}$; e, contudo, a disposição do pronome no começo da oração, em situações específicas, isola-o e enfatiza a contraposição existente entre o sujeito psicológico e o conteúdo do lexema predicativo $^{52}$. É natural que os pronomes pessoais de primeira e segunda pessoa, substantivos que marcam explicitamente a seu referente específico, se encontrem na posição extrapositiva. $\mathrm{Na}$ oração verbal expressa-se a extrapositividade pela da pessoa do verbo.

Quando a extraposição é um substantivo, seu rastro será representado pelo pronome pessoal coindexado com a extraposição. Quando a extraposição em si é um pronome pessoal, seu rastro será o mesmo pronome pessoal ou a reiteração do gênero e número no verbo conjugado (que é o predicado da oração formal). O pronome pessoal de terceira pessoa "ele" (הוא-) por si só não marca alguém específico (cada um pode ser "ele" em relação ao "eu" e ao "tu"), e, portanto, encontra-se em abundância como rastro em orações de conteúdo geral, sendo declarativo ou descritivo. As orações extrapositivas, onde os pronomes pessoais de primeira e segunda pessoas aparecem no sujeito extraposto ou no rastro, são mais características para expressar sentimentos; é por isso que possuem uma mensagem de oposição, desculpas ou ofensa. De qualquer maneira, a reiteração do pronome enfatiza a extraposição. Exemplos:

${ }^{51}$ Segundo Schwartzwald: "En el hebreo moderno no hay un énfasis especial que acompañe al pronombre que encabeza la oración, y por ende no son consideradas oraciones extrapuestas. Extraposición de pronombres personales podremos encontrar sólo en los siguientes casos: a) el pronombre es diferente del sujeto psicológico de la oración." (Pág. 332). Como prova disso, ela traz as seguintes orações: "Ella, Dan la quiso mucho." (היא דן אהב אותה מאוד); "Él, Dan se sentó sobre él." (sobre su padre) (sin cita de fuente) (מוא דן ישב עליו); "Yo, mi familia vino a Israel de Marruecos y

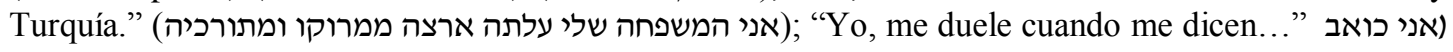
לי כשאומרים... (señala que estas oraciones son de Maariv, 27 de noviembre de 1974). Várias das orações que recopilei para esta pesquisa mostram de fato que a situação é diferente.

52 Ver Goldenberg, El Verbo: "Si vemos que los componentes del complejo verbal son los que conllevan la posición en las estructuras sintácticas, ya que de esta manera reconocemos que las relaciones sintácticas atraviesan siempre los límites morfológicos en todas las estructuras que contengan un verbo conjugado (Pág. 324) y por esto "la extraposición de la persona que el verbo está conjugada y la extraposición del contenido lexical del verbo se diferencian uno del otro" (Pág. 328). 
1- Ella es más alta que yo, y bonita, y yo quién soy yo? (Oz, Kufsá, Pág. 192).

- היא גבוהה ממני, ויפה, ואני מי אני בכלל?

Esta oração é uma substantiva interrogativa cujo conteúdo é apologético e expressa frustração, e a reiteração do pronome pessoal é exigida pela própria estrutura da oração. O interrogativo quem (מי), exige a presença deste pronome pessoal.

2- \&2.3.4, oração 3 .

3- ...porque tú mejor para ti que hubieras dejado de crecer... (Oz, Kufsá, Pág. 46). - .... כי אתה יותר טוב לב שהיית מפסיק כבר לגדול...

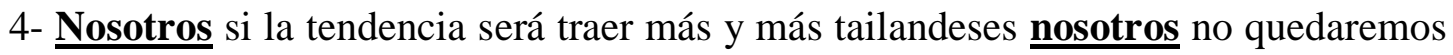
sin animales. (Entrevistado en la televisión, 14 de noviembre 2004).

- אנחנו אם המגמה תהיה להביא עוד ועוד תאילנדים אנחנו נישאר בלי חיות.

5- ú , pensé que tú eras mi amiga. (Linor, Pág. 163).

- את, חשבתי שאת חברה שלי.

Neste último exemplo, a oração formal é composta de uma subordinada e, dentro desta oração subordinada, encontramos o rastro. A estrutura desta oração exige a presença do pronome dentro da subordinada e isso é para dar transcendência ao predicado.

\subsection{A extraposição é um substantivo ou um pronome com seu rastro no modificador} direto da oração formal

Uma oração extraposta, cuja extraposição é um substantivo ou um pronome e seu rastro na oração formal está na posição de modificador direto, é muito comum. Geralmente o rastro é um pronome pessoal concordando em gênero e número ${ }^{53}$ com o

${ }^{53}$ Em hebraico pode-se declinar os substantivos e preposições, acrescentando-lhes um sufixo. 
elemento extraposto, ainda que haja também casos em que o rastro é um pronome demonstrativo 54 .

A extraposição é transparente quando o elemento extraposto é um substantivo e o rastro é um modificador direto (adjetivo) declinado ${ }^{55}$; neste caso o rastro da extraposição está no modificador direto do sujeito da oração formal. Desta maneira, colocando-se o sujeito da oração formal na posição do sujeito da extraposição, obtém-se a oração original.

"Un hombre, que pasó tres guerras y no le dan el registro de conducir por una crisis temporaria, su situación es muy difícil" fue extraída de "La situación de un hombre que pasó tres guerras y no le dan el registro de conducir por una crisis temporaria, es muy difícil".

"אדםם, שעבר שלוש מלחמות ונשלל ממנו רשיון הנהיגה בגלל משבר זמני - מצבו קשה מאוד" "מצבו של אדם, שעבר שלוש מלחמות ונשלל ממנו רשיון הנהיגה בגלל משבר זמני, קשה מאוד".

Distinta é a situação, quando a extraposição é um pronome pessoal; aqui a omissão deste pronome anula a extraposição e obteremos a oração original. Por exemplo:

Y yo, sin quejas de su parte mis manos están atadas- sin quejas de su parte mis manos están atadas.

- ואני בלי תלונה מצדו הידים שלי קשורות- בלי תלונה מצדו הידים שלי קשורות.

Ellos, su trabajo es comprar entradas- Su trabajo es comprar entradas

- הם, תפקידם לקנות כרטיסים- תפקידם לקנות כרטיסים.

\footnotetext{
${ }^{54}$ Ornán comenta que "a veces la huella no puede ser un pronombre personal sino únicamente un pronombre demostrativo, como por ejemplo: `lo que los enemigos de Sión argumentaron todos estos años- que los líderes del sionismo diaspórico están conducidos por el gobierno israelí- el gobierno de Israel proporcionó para ello ahora una prueba contundente"” (Haaretz, 12/3/67, Pág. 2) (Pág. 105). Neste exemplo o rastro, que é um pronome pessoal neutro, não é um modificador direto senão um objeto indireto.

${ }^{55}$ Em hebraico existe a possibilidade de declinar um elemento nominal.
} 
Isto significa que, quando em uma oração há um substantivo acompanhado por seu possessivo, esta oração pode ser convertida em extraposta pela representação pronominal do possessivo no começo da oração.

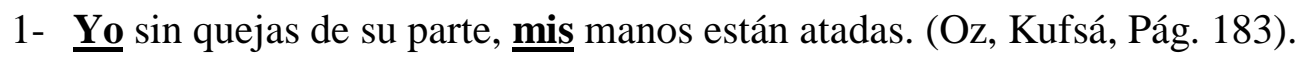

- אני בלי תלונה מצדו הידים שלי קשורות -

2- Ellos, su trabajo es comprar entradas. (Guiora Shpiguel, cita del diario Haaretz, 12 de agosto 2004).

- הַם, תפקידבם לקנות כרטיסים.

3.6.1 Um rastro, que é modificador direto, aparece em orações extrapostas substantivas e similares às orações comparativas.

Nesta estrutura, as palavras pertencentes ao grupo semântico de "interpretação" funcionam como sujeito da oração formal. O conteúdo lexical das palavras, pertencentes a este grupo semântico está muito desgastado ${ }^{56}$ e o elemento importante nelas é o rastro como modificador direto; portanto, podemos trocá-las por um pronome pessoal ou demonstrativo sem que se modifique significativamente o conteúdo da oração, mantendo-se o valor comparativo da mesma. Exemplos:

1- $\underline{\text { La renuncia a la lealtad }}$ significa $^{57}$ el fin del movimiento liberal. (Ran Kislev, Diario Haaretz, 29 de agosto 2004). - ויתור על נאמנות משמעותוַ סופה של תנועת החרות (רן כסלו, הארץ, 2 באוגוסט 1994).

Substituído por um pronome pessoal, seria:

La renuncia, ella será el fin del movimiento liberal.

2- $\underline{\text { La extradición del Templo en manos de un dirigente extranjero se explica }}{ }^{58}$ como el abandono del Santo Santuario de la nación en manos de ajenos. (Nadav Shragai, Diario Haaretz, 2 de agosto 2004).

\footnotetext{
${ }^{56}$ São palavras que, com o tempo, perderam seu valor semântico.

${ }^{57}$ Com a tradução para outro idioma, neste caso, é impossível ver o rastro.
} 
A substituição por um pronome demonstrativo ou pessoal seria:

La extradición... esto o ella sería como el abandono...

3- Comprar un banco no significa dirigirlo. (Entrevistado en la televisión, 29 de noviembre 2004).

- לקנות בנק אין פירושו לנהל אותו.

A substituição por um pronome demonstrativo seria:

Comprar un banco esto no sería dirigirlo.

Neste tipo de estrutura podemos encontrar também palavras, que propõem um elemento temporal ou espacial, posicionadas como sujeito da oração formal. Exemplos:

1- La consolidación de esta oposición en la institución, $\underline{\text { su }}$ comienzo fue en junio de 1966. (Cesar, Pág. 109).

- התגבשותה של אופוזיציה זו בתוך הממסד, ראשיתה ביוני.

2- El triunfo su final está en la disculpa. (Efraim Rainer, Diario Haaretz, 23 de noviembre 2004).

- גם ההצלחה סופה בהתנצלות.

3- El territorio palestino en $\underline{\mathbf{s u}}$ mayoría es una planicie y casi no tiene montañas. (Siván, Pág. 174).

- שטח פלסטין רובַ מישור ואין בו כמעט הרים.

De acordo com o que se pode apreciar, pelos exemplos aqui mencionados, parece ser característico encontrar este tipo de orações na linguagem da imprensa.

\footnotetext{
${ }^{58}$ No caso do hebraico, como em outras línguas, há palavras, especialmente preposições, que provêm da fusão de outras palavras cujo significado original se perdeu.
} 


\subsection{A extraposição é uma oração subordinada}

Nas seguintes orações, nas quais a mensagem é declarativa, as orações subordinadas extrapostas têm a seguinte estrutura - pronome relativo ${ }^{59}+$ que $^{60}+$ oração adjetiva cujo predicado é um verbo ou um adjetivo derivado de um verbo. O rastro que aparece na oração formal pode referir-se tanto à pessoa implícita no verbo (ou no adjetivo) que aparece na subordinada como a outro elemento da subordinada. Exemplos:

1- Quien tanto se cuida ${ }^{61}$ de los hombres, es lógico que alguien se entienda con ella. (Laor, Pág. 182).

- מי שכל כך נזהרת מגברים, הגיוני שמישהו יחליט להתחשבן איתה.

2- Quien reciba la dirección, tendrá con él el derecho total de nombrar un equipo confiable. (Diario Haaretz, 9 de agosto de 2004).

- מי שיקבל עליו את הניהול, תהיה לַ את הזכות המלאה למנות צוות אימון

3- Quien $\underline{\text { su }}$ padre y madre ya murieron, y esposa no tiene e hijos tampoco, él no necesita apellido. (Shalev, Pág. 267).

- מי שאבא ואמא שלו כבר מתו, ואשה אין לו וילדים אף פעם לא יהיו לו, הוא לא צריך שם משפחה.

\subsection{A extraposição é o nome de um lugar}

Existem orações nas quais a extraposição é o nome de um lugar:

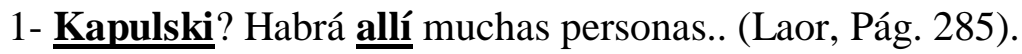

- קפולסקי? יהיו שם המון אנשים.

\footnotetext{
59 Neste caso estas subordinadas começariam com "mi" que significa quem (pronome relativo). Quando aparece o "she" que significa "que" (pronome relativo), as duas palavras juntas passam a interpretar-se como "o que..." o "quem...".

${ }^{60}$ Em espanhol posso começar a subordinada com "el o la que", o con "quien". Minha opção será escrever "quien" mas, neste caso desaparece o pronome "que", com o qual se introduz a subordinada.

${ }^{61}$ É importante esclarecer que, embora em español não se distinga o gênero em hebraico a morfologia verbal revela, neste caso, o gênero.
} 
2- Bélgica, hace dos meses enterré a $\underline{\text { su }}$ rey. (Ezer Waitzman en la radio, 14 de mayo de 1994, citado en el Diario Haaretz el 29 de diciembre 2004).

- בלגיה, לפני חודשיים קברתי את המלך שלכם.

3- $\underline{\text { Suiza! }}$ Otra vez Suiza! Esto los pone nerviosos, no es así? (Efraim Kishon en la radio, 14 de octubre 1994, citado en Haaretz el 29 de diciembre 2004).

שוויצ! שוב שויצ! זה מרגיז אתכם, נכון?

Na oração 1 a extraposição está representada na oração formal por um circunstancial. $\mathrm{Na}$ oração 2 o rastro está representado pela declinação do pronome de como um modificador direto. $\mathrm{O}$ nome do lugar é um substantivo e a evidência que marca um lugar não modifica sua posição substantiva.

\subsection{A extraposição é uma pergunta}

Quando a oração interrogativa começa com um pronome interrogativo e não revela

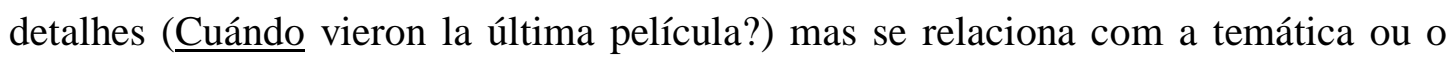
personagem principal revelando os detalhes posteriormente (Dani? Lo vi ayer), esta oração se isola por natureza e, portanto, é provável que haja orações extrapostas que são interrogativas, e a interrogação é a extraposição em si; o signo de interrogação se coloca depois da extraposição, mas pode aparecer ao final da oração.

Esta estrutura concorda com a visão de Brafman $^{62}$ sobre a formação da extraposição. Exemplos:

1- El chico? Puedes llevarlo así? (Grosman, Pág 163).

- הילד? מותר לך לקחת אותו ככה?

2- Dime, ese $\underline{\text { Tal Spector, }}$ ese que perseguías con la cámara, obtuviste algo de él al final? (Linor, Pág. 36)

- תגידי, הטל ספקטור האוויל הזה, זה שהיית רצה אחריו עם מצלמה, יצא לך ממנו משהו בסוף?

${ }^{62}$ Ver Brafman, Pág. 182. 
3- Ella es más alta que yo, y bonita, y yo quién soy yo ? (Oz, Kufsá, Pág. 192).

- היא גבוהה ממני, ויפה, ואני מי אני בכלל?

\section{Questões de concordância na extraposição}

Basicamente há concordância de gênero e número entre a extraposição e o rastro. Nas duas primeiras orações que seguem de exemplo, a extraposição está composta por um substantivo e um modificador direto e o rastro concorda com algum dos dois elementos; não obstante, nas duas últimas orações, cuja origem é da linguagem coloquial, não há concordância gramatical formal entre o elemento extraposto e seu rastro, e isto se deve a que o falante se dirige aos presentes e, para isto, necessitou-se de um pronome pessoal de segunda pessoa que concorda com as circunstâncias do assunto a tratar:

1- La verdad es que yo dudo con alguien como tú, villano y malvado que echas cosas perversas, si hay en ti un respeto hacia el creador o siquiera un respeto hacia la conciencia. (Oz, Kufsá, Pág. 185).

- האמת היא שאני מפקפק אם אחד כמוב, רשע מועד ונבל אשר דבר־בליעל יצוק בו, אם יש עליב בכלל איזה מורא שמים או אפילו מורא מצפון.

2- Era claro para mí que con alguien como yo, no había posibilidad que el destino dispare a su alrededor el hombre en el que ella estaba interesada. (Linor, Pág. 61). - היה לי ברור שמישהי כמוני, אין שום סיכוי שהגורל יטיל לסביבתה את הגבר שהיא היתה

3- Para aquellos que aman a Machini, les quiero contar a ustedes que Manchini era... (El violinista Itzchak Perelman en el Auditorio de la Cultura, 29 de diciembre del 2004).

- אלה שאוהבים את מנציני, אני רוצה לספר לכם שמנציני היה ... 
4- $\underline{\text { Bélgica, }}$, hace dos meses enterré a $\underline{\text { su }}$ rey. (Ezer Waitzman en la radio, 14 de mayo de

1994, citado en el Diario Haaretz el 29 de diciembre 2004).

- בלגיה, לפני חודשיים קברתי את המלך שלכם.

\section{5-Extraposicão traseira ou posterior}

Como foi dito antes, Jaspersen analisa a extraposição dianteira e traseira e estabeleceu que a extraposição traseira é do tipo "After thought ${ }^{63}$ ". Pelo contrario, os linguistas que analisaram a extraposição em hebraico ocuparam-se principalmente da extraposição dianteira seja em suas pesquisas como na própria definição do fenômeno (ver Ornán ${ }^{64}$ e Scwartzvald ${ }^{65}$ ). Segundo o inventário das orações expostas nesta pesquisa, existem estruturas determinadas que devem ser entendidas e tratadas como uma extraposição traseira.

A extraposição é um caso especial de aposição ${ }^{66}$. Nas orações em que há extraposição dianteira não pode haver proximidade entre os elementos paralelos com respeito a seu lugar na oração, isto é, o rastro aparece na oração formal longe do elemento extraposto. No caso da extraposição traseira, as orações são similares àquelas com aposição sintática, isto é, os elementos paralelos devem estar juntos. Este fato pode gerar problemas para diferenciar estes fenômenos ${ }^{67}$, ainda que esta similitude estrutural não deva prejudicar a distinção deste fenômeno. Na oração

Cómo ellos se atreven, estos árabes? (Shif- Ya'ari, Pág. 141)

איך הם מעיזים, הערבים האלה?

\footnotetext{
${ }^{63}$ Ver rodapé 11.

${ }^{64}$ Ver Ornán, Pág. 102, "Todos conocen que el origen de la extraposição está en otra oração. De esta oração se extrae un elemento para ubicarlo fuera de la misma, al comienzo".

${ }^{65}$ Scwartzvald, Pág. 340.

${ }^{66} \mathrm{O}$ uso do conceito aposição, neste caso, se refere ao paralelismo de um membro da oração com outro membro; o conceito "aposição sintática" corresponde ao significado limitado do modificador direto, que é um substantivo que descreve outro substantivo, e sua posição sintática é igual ao outro substantivo e podendo haver troca entre eles.

${ }^{67}$ Ver rodapé 11.
} 
a frase estos árabes é uma extraposição. Caso se passe esta frase para frente ficando “Estos árabes, cómo ellos se atreven”, não mudaria o conteúdo da oração e, sem dúvida, seguiríamos na presença de uma extraposição. O mesmo acontece com

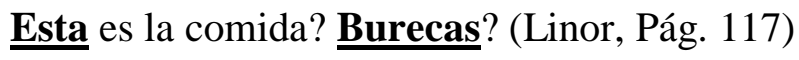

זה האוכל? בורקס?

e com a oração:

"En él eso está en su sangre, el espionaje”. (Grossman, Pág. 78) אצלו זה בתוך בדם שלו, הבלשות.

As palavras "burecas" e "espionaje" seriam como uma "segunda leitura"; a passagem destas palavras para o começo da oração não modificaria seu conteúdo ou sua estrutura, somente faria mais transparente o fato de ser uma extraposição.

Nas orações em que há aposição (que não está perto da extraposição), a extraposição deve sofrer uma mudança estrutural. Por exemplo, na oração "Rabin apretó la mano de Husein, el rey de Jordania", a aposição está ao lado do objeto direto; extrapor a aposição exige uma troca estrutural pela anulação do substantivo que está ao lado da aposição, e assim se obtém a oração "El rey de Jordania, Rabin apretó su mano", ou extrapondo o substantivo e a aposição juntos: "Husein el rey de Jordania, Rabin apretó su mano". De qualquer maneira, é provável que não encontremos uma oração como "Husein, Rabin apretó la mano del rey de Jordania". Quando resulta difícil estabelecer se temos diante de nós uma extraposição ou uma aposição, como na seguinte oração “Él será Bar Mitzvá en unos días, e pensé - ahora é el momento para encontrarnos. Yo e Amnon.” (Grosman, Pág. 164), a diferenciação se pode provar coolocando o que se considera extraposição ou aposição no começo da oração e, se desta maneira não se modifica o conteúdo da oração, há que vê-lo, segundo minha concepção, como uma extraposição traseira: "Yo e Amnon. Ahora é el momento para encontrarnos" é uma oração com extraposição. Posicionar "Yo e Amnon" no começo da oração não mudou a estrutura da primeira oração. Na continuação haverá outros exemplos. 


\subsection{A extraposição é um substantivo e na oração formal há um elemento que a sinaliza, e sua posição é de sujeito.}

1- Esto me salió mucho dinero, la leche el divorcio y los juicios y todo (Shalev, Pág. 183).

- זה עלה לי הרבה כסף, החלב והגט והמשפטים והכל.

2- Ella es un espécimen, tu madre, dijo Meir. (Shalev, Pág. 284).

- היא טיפוס, אמא שלך, אמר מאיר

O rastro é um pronome pessoal na terceira pessoa do singular quando se trata de pessoas definidas. O pronome demonstrativo "este" será o indicador quando o sujeito é um tema geral.

\section{$\underline{5.2 \text { A extraposição é um substantivo e na oração formal o rastro é o predicado. }}$}

3. Yo creo que esto es lo que nos debilita, esta terrible eximisión. (Shulamit Aloni en televisión, 7 de diciembre de 2004).

- אני חושבת שזה מה שמחליש אותנו, הפתור הנורא הזה.

Nesta oração o pronome demonstrativo da extraposição traseira é o predicado; a presença da extraposição traseira aqui é obrigatória, já que se não aparece, não se entende a primeira parte. Somente a segunda parte aclara a oração e lhe dá sentido.

\subsection{A extraposição e o rastro são um substantivo.}

4- Y yo estoy en contra de que tú controles el dinero que me pertenece a mí y a Ilana, el dinero de América, y tú todo el tiempo estableces mi vida. (Oz, Kufsá, Pág. 100). 
- ואני נגד זה שאתה שולט על הכסף ששייך לי ולאילנה הכספ מאמריקה ואתה כל הזמן קובע לי

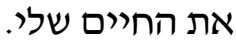

Nesta oração, a extraposição, que é um substantivo, é idêntica ao substantivo que aparece no rastro na oração formal; seu posicionamento tem como objetivo enfatizar o assunto do dinheiro, já que é o principal problema que esta carta quer mostrar.

\section{6- A extraposição verbal}

Não se deve discutir a extraposição do verbo como um fenômeno geral mas sim, como argumentou Goldenberg ${ }^{68}$, há que diferenciar entre os elementos do verbo (sinalização do pronome, o lexema predicativo e a conjunção entre eles) e em concordância com isto, devemos diferenciar também entre a extraposição do pronome implícito no verbo e entre a extraposição de seu conteúdo lexical. Quero dedicar-me agora à extraposição do conteúdo lexical do verbo.

Com respeito à "fonte tautológica", o infinitivo no começo da oração", estrutura muito utilizada em diversas línguas, Goldenberg estabelece que esta colocação o transforma em um "sujeito lógico" privado de tempo, modalidade, gênero e número. Goldenberg estabelece: "It is obvious, however, that a verb cannot be represented by a pronoun, and with no proverb (i.e. vicarious verb) available, tautological ${ }^{70}$ repetition is compulsory". Sobre a extraposição do conteúdo lexical do verbo neste tipo de estruturas discute também Ornán ${ }^{71}$. Ele pensa que "geralmente a extraposição do verbo aparece quando o verbo se utiliza como predicado da oração formal, cujo conteúdo é oposto à extraposição ou a desaprova".

Do ponto de vista da posição da extraposição do verbo, as orações nesta pesquisa são de dois tipos: orações nas quais o verbo aparece extraposto no começo e orações nas quais aparece o verbo extraposto ao final. Ainda que a literatura sobre este tema trate principalmente da extraposição verbal dianteira, nas orações seguintes vê-se que a

\footnotetext{
${ }^{68}$ Ver Goldenberg, El Verbo, Págs. 328- 329.

${ }^{69}$ Ver Goldenberg, "Tautological Infinitive". Ampla análise deste tema, sobre vários exemplos de outras línguas semitas.

${ }^{70}$ Ibid., Pág. 67.

${ }^{71}$ Ver Ornán,, Págs. 113- 114.
} 
extraposição traseira existe também com os verbos. Também com respeito à reiteração e representação do verbo no corpo da oração formal, há dois tipos de orações: orações cuja reiteração se vê no rastro, por de um verbo conjugado proveniente da raiz do verbo extraposto, e orações nas quais a reiteração se vê no rastro por de um pronome (relativo ou pessoal) que se refere ao verbo extraposto. $\mathrm{Na}$ maioria das orações nas quais o verbo se extrapõe no começo e sua representação na oração formal provém da mesma raiz do infinitivo extraposto, o verbo fica excluído.

É lógico que o posicionamento do infinitivo no começo da oração apareça pela necessidade de enfatizar a oposição entre o que se podia haver feito, o fundamental do feito, expressado na forma infinitiva (roubar $=$ em referência à [possibilidade de] $\mathrm{o}$ roubo), e entre as coisas que se fizeram ou poderiam fazer, que se expressa na forma conjugada do verbo na oração formal. Nas orações nas quais o verbo está extraposto no final, no corpo da oração encontramos um pronome que a antecede, como em todas as instâncias onde a extraposição é traseira. Neste tipo de orações o pronome é demonstrativo, e seu posicionamento lá é muito natural, já que se refere a um assunto geral. As orações com extraposição verbal têm uma carga emocional importante, sobretudo as orações onde o verbo está em extraposição dianteira.

\subsection{Um verbo infinitivo em extraposição dianteira}

\subsubsection{A reiteração, no corpo da oração, é o verbo conjugado da mesma raiz}

A maioria dos exemplos deste tipo de orações aparece com Shalev. O uso desta estrutura corresponde ao estilo característico da linguagem falada de um dos personagens do livro. Por exemplo:

1. Comer yo comí hiervas, y agua tomé del río. (Shalev, Pág. 29).

- לאכול אני אכלתי עשבים, ומים אני שתיתי מהנהר.

Esta oração está composta por duas orações paralelas em uma mesma estrutura. O infinitivo comer tem como paralelo o substantivo água; o paralelo do pronome é um pronome e o paralelo do verbo conjugado é o verbo tomé, que caracteriza o substantivo agua. 
2. $\underline{\text { Agarrar }}$ yo no agarro de nadie y robar yo no robo, pero codiciar, Zaida, yo codicio, y envidiar yo envidio. (Shalev, Pág. 30)

- לקחת אני לא לוקח מאף אחד ולגנוב אני לא גונב, אבל לחמוב, זיידה, אני חומד, ולקנות אני

מקנא.

3. Joder tu no jodes, pero espiar las cartas de otros eso es correcto para ti. (Laor, Pág. 51).

- להזדיין את לא מזדיינת, אבל להציץ במכתבים של אחרים זה בסדר מבחינתך.

Na oração 3 há duas orações paralelas; a primeira tem uma origem tautológica e um verbo conjugado negado; a segunda é seu paralelo oposto, cujo sujeito é um infinitivo mas sem reiteração em um verbo conjugado senão em um pronome demonstrativo. É assim que, em lugar de pero espiar las cartas de otros tú espías, temos pero espiar las cartas de otros eso es correcto para ti. Pode-se supor que a causa desta estrutura é que o verbo na segunda oração não está negado e por isto se preferiu uma estrutura substantiva.

\subsubsection{A reiteração no pronome}

1. Comprar un banco no significa dirigirlo dirigirlo (Entrevistado en la televisión, 29 de noviembre 2004).

- לקנות בנק אין פירושו לנהל אותו.

2. Es cierto que cualquier abandonada, toda aquella que se niega al divorcio, es un mundo aparte. Pero llegar desde aquí al argumento que hay miles de abandonadas que niegan el divorcio- esto es una exageración ridícula. (Diario Haaretz, 29 de noviembre 2004, cita del Rabino central).

- נכון שכל עגונה, כל מסורבת גט, היא עולם ומלואו. אבל להגיע מכאן לטענה שיש אלפי עגונות

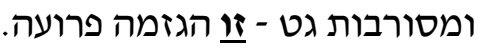

3. Hacer el mal y deprimirlo, significa enseñarle. (Sivan, Pág. 201). 
- לעשות לו את הרע ולדכאו, פירושו ללמדו.

4. Preguntar, eso no cuesta dinero. (Oz, Kufsá, Pág. 128)

- לשאול, זה לא עולה כסף.

Nestas quatro orações o rastro indica o infinitivo extraposto: Nas orações 1 e 3 o rastro é um modificador direto que, em hebraico, está anexado ao substantivo que modifica; nas orações 2 e 4 o rastro é um pronome demonstrativo.

\section{$\underline{6.2 \text { Extraposição traseira }}$}

1. Yo espero que esto no sea considerado como una vulgaridad, pero yo pienso que esto fue una decisión muy considerada de tu parte, bañarte antes. (Laor, Pág. 99). - אני מקווה שזה לא נחשב לגסות רוח, אבל אני חושב שזאת היתה החלטה מאד מתחשבת

מצידך, להתקלח קודם.

2. Esto es realmente de mal gusto pelear con los religiosos, oponerse a Rabin, oponerse a los bombardeos en el Líbano, preocuparse $^{72}$ por el bienestar de los palestinos. (A. Shochet, Haaretz, 7 de agosto 2004).

- זה ממש לא בון-טון לריב עם הדתיים, להתנגד לרבין, להתנגד להפצצות בלבנון, לדאוג לרווחת

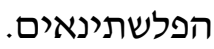

3. Esto frustra, verlos refugiarse así. (Yediot Hacharonot, 15 de agosto 2004). - זה מתסכל לראות אותם נמלטים ככה.

4. Esto ya te pasó en el pasado, continuó, así, desmayarte en el medio del día? (Mendelson, Pág. 46). - זה כבר קרה לך בעבר, המשיכה, ככה, להתמוטט באמצע היום? (מנדלסון, עמי 46).

Quando o verbo em extraposição traseira segue a regra que recai sobre os outros membros da oração que se encontram nesta posição, pode-se passa-lo ao começo da

\footnotetext{
${ }^{72}$ Neste caso, para que a oração fique mais clara, poder-se-ia antepor à extraposição a conjunção "es decir".
} 
oração sem modificações em sua estrutura. A característica sintática desta estrutura é a impossibilidade de colocar um verbo conjugado da mesma raiz antes do infinitivo. As orações assinalam um assunto não definido, e por isso se usa o pronome demonstrativo como o rastro que antecede a extraposição. Um dos membros que indica uma atividade é o infinitivo, mas na mesma medida poderia aparecer o substantivo derivado do verbo. Por exemplo, no lugar de - $\underline{\text { Esto }}$ no es tu asunto

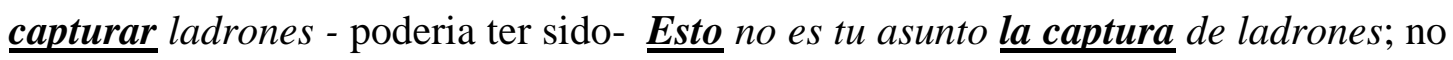
lugar de- $\underline{\text { Esto }}$ es realmente de mal gusto pelear con los religiosos, oponerse a Rabin ...- poderia ter sido- $\underline{\text { Esto }}$ es realmente de mal gusto la pelea con los religiosos, la oposición a Rabin ...

\section{7- Orações de estrutura análoga àquelas com extraposição.}

No item 2.1 introduzi as orações extrapostas sem rastro morfológico. O motivo de chamá-las ainda assim orações extrapostas deve-se a que o rastro se infere do contexto. Além destas orações já analisadas, apareceram três orações diferentes, nas quais não há um rastro morfológico, tampouco fica claro se este rastro se infere do contexto geral, mas são muito parecidas estruturalmente às orações extrapostas carentes de rastro. Estas são as orações:

1. Continuando con nuestra conversación de ayer: nosotros necesitamos en total de un monto de... (Oz, Kufsá, Pág. 18).

- בהמשך לשיחתנו הטלפונית מיום אתמול : אנחנו זקוקים בסך הכל לסכום של...

Esta oração, que começa com uma frase adverbial, é muito similar à estrutura das orações com En cuanto $a$... (ver o item 2.3.1), mas sem rastro e tampouco a reiteração se infere claramente do contexto.

2. Puede ser que el Hamas no pueda evitar de la Organización para la liberación de Palestina avanzar en dirección a los acuerdos, pero dificultar y complicar, es seguro que estará en sus manos. (Shef Ya’ari, Pág. 245). 
- אפשר ש״חמאס" לא יוכל למנוע מאש״ף להתקדם בכיוון של הסדרים, אך להכביד ולשבש,

A localização da frase "dificultar y complicar" no começo da oração e seu isolamento pela vírgula gera uma ênfase importante. Se colocarmos esta frase no final da oração, o significado não muda em absoluto, como se esperaria, só que dá a sensação de que perderia muita força e importância em sua capacidade de complicar y dificultar. De fato, pode-se supor que a oração original, aquela em que o falante pensou antes de emitir esta oração, seria “dificultar e complicar”. É certo que estará em suas mãos “dificultar e complicar”, mas, como este tipo de redundâncias não é permitido em hebraico, a colocação desta frase no começo evita esta repetição deixando o verbo de ligação sem complemento.

3. Muchos objetos importantes para este tipo de culto, estos historiadores pueden encontrar en las escuelas intelectuales, especialmente en estas escuelas... (Siván, Pág. 79).

- מושאים רבים וחשובים יותר לפולחן מעין זה, היסטוריונים אלה יכולים למצוא בחוגי האינטלקטואלים, ובייחוד באותם חוגים...

Nesta oração o objeto foi passado para o começo da oração, e só a falta da reiteração, neste caso estos historiadores $\underline{\text { los }}$ pueden encontrar, אותם em hebraico impede sua conversão total em estrutura extraposta. $\mathrm{O}$ pronome que falta na oração formal seria um objeto cuja ausência, como já se disse anteriormente, é muito comum de ver no hebraico moderno. 


\section{8- Conclusão parcial e avaliações}

A construção gramatical denominada extraposição caracteriza-se pela aparição de um constituinte em uma posição (à esquerda ou à direita da frase) que se copia anaforicamente na predicação por um pronome coindexado.

Diferenciamos nela uma parte extraposta a que podemos chamar sujeito psicológico e outra parte chamada oração formal que não está subordinada à primeira parte extraposta. A conversão de uma oração simples em uma extraposta consiste em uma troca de estrutura colocando um dos componentes da oração como sujeito psicológico.

O isolamento e a reiteração são características pronunciadas da extraposição, mas nem sempre a reiteração tem expressão morfológica na oração formal, e às vezes surge do contexto. Isto faz pensar de outra maneira a ideia de extraposição, já que a condição necessária para que a extraposição exista é o isolamento. Este isolamento tem níveis, sendo o nível de menor isolamento aquele cuja extraposição é para a direita.

Pode-se extrapor qualquer parte da frase, sendo a maior porcentagem os objetos e a menor os locativos. 


\section{Capitulo 3- Shum Gamadim Lo Iavohu (Nenhum anão virá)}

Este livro, "Shum gamadim lo Yavohu" (Nenhum anão virá), é uma história contada pela família Dadón, Simona e seus filhos. Sara Shiló, a autora, escreve com uma linguagem muito pobre, em um idioma dos bairros da baixa periferia. Apesar de escrever em uma linguagem natural do povo, a autora consegue dar voz própria a cada um dos personagens, criando um discurso característico para cada membro da família.

Segundo alguns críticos, como M.Y. para Matityaho Wordpress ${ }^{73}$ ou Dan Lachman para e-mago.co.il ${ }^{74}$, a cidade onde se passa a história é Kiriat Shmoná. Segundo outras fontes como Maya Feldman para Ynet $^{75}$ ou Almog Bahar para Shunrá ${ }^{76}$, a cidade é Maalot. Quando analisamos a história de Kiriat Shmoná, não podemos deixar de mencionar o ataque de terroristas em 1974, quando morreram muitas pessoas. Por outro lado, no mesmo ano, na cidade de Maalot também houve um ataque terrorista com muitos mortos. Apesar dessas duas evidências, há uma forte tendência em pensar que a cidade é Maalot e não Kiriat Shmoná e os motivos principais são que, além do ataque terrorista de 1974, esta cidade sofreu durante muito tempo com ataques de mísseis Katyushas, como acontece no livro.

Por outro lado, a escritora, Sara Shiló, viveu por 16 anos nesta cidade, e esta talvez seja a causa de la ter podido descrever com tanta precisão a vida e os costumes dos habitantes em seu romance. Seja qual for a cidade, Sara Shiló constrói um paralelismo entre a explosão dos mísseis, e a que gera a morte do núcleo familiar com a morte do pai. Esta explosão pode ser projetada em diferentes lugares da cidade, no campo de futebol, na aldeia árabe, na escola, no abrigo do bairro e no armário.

\footnotetext{
כלום-יכולה-קרית-שמונה-לדבר-מזל-טוב-לשר/20 http://matityaho.wordpress.com/2007/06/12

${ }^{74}$ http://www.e-mago.co.il/Editor/literature-735.htm

${ }^{75} \mathrm{http}: / /$ www.ynet.co.il/articles/0,7340,L-3191337,00.html

${ }^{76}$ http://www.blabla4u.info/sites/blabla4u/ShowMessage-eng.asp?LangCode=Heb\&ID=4169980
} 
A linguagem cotidiana da família não é "padrão", não é "literária" atraindo o olhar do leitor e conduzindo-o ao longo do relato.

Este livro sofreu muitas críticas. Grandes escritores disseram que, para poder traduzilo para outros idiomas, seria necessário primeiro traduzi-lo para o hebraico.

Apresento aqui alguns excertos de críticas que foram escritas em jornais impressos e Internet, quando o livro foi lançado para venda.

\section{1-O livro nos jornais- críticas}

עיתון הארץ, 28 בדצמבר 2005, במאמר "קראו וירחב לבבכם ", מאת דרור בורשטיין.

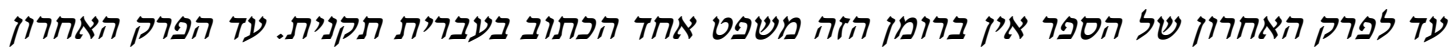

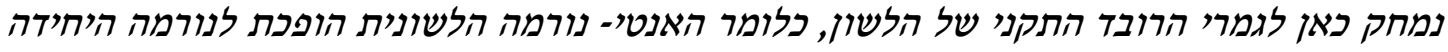

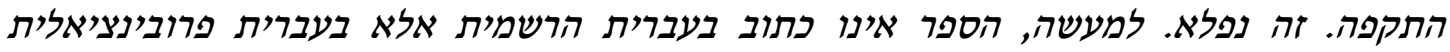

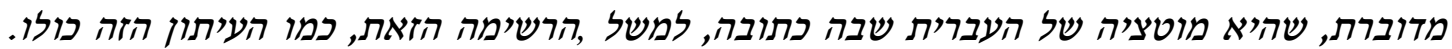

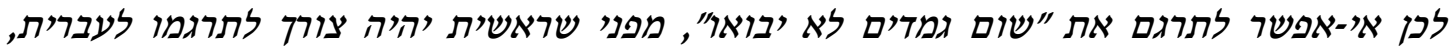
ומשימה זו עצמה אינה בת-ביצוע מבלי להרוס את הרומן.

Jornal "HaAretz", 28 de dezembro de 2005, no artigo "Leiam e expandam seu coração" de Dror Burshtein.

Até o último capítulo do livro, não há em todo o romance uma oração escrita em hebraico correto. Até o último capítulo apaga-se por completo a etapa padrão da língua, quer dizer, a antinorma idiomática se transforma na única forma vigente. É incrível. Na verdade, o livro não está escrito em um hebraico oficial, senão em um hebraico provinciano e oral, que é uma mutação do hebraico escrito, por exemplo, o hebraico que se escreve neste jornal. Portanto, é impossível traduzir "Shum gamadim lo iavohu", já que primeiro se faria necessário traduzi-lo para o hebraico e fazer isso seria inviável sem destruir o romance. 
שלומית ליר (חוקרת תרבות ופעילה פמיניסטית חברתית). - עולם חדש נקימה. 6 במאי 2006. http://www.notes.co.il/lir/18064.asp

שילה פועלת כנגד ההתנשאות וההכפפה הנגזרות מידע השפה התקנית תוך שהיא משחררת את הדמויות מהמחויבות לדיבור קאנוני ומאפשרת להן לדבר בשפת היום יום שלהן. היחידה שמפנימה את העברית הגבוהה והמצוחצחת היא בת המשפחה אתי דדון. אתי, המאזינה

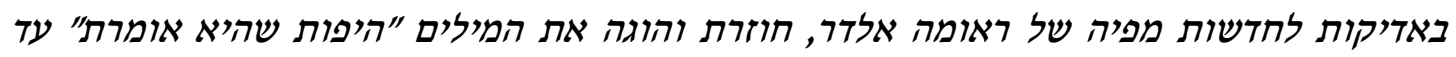

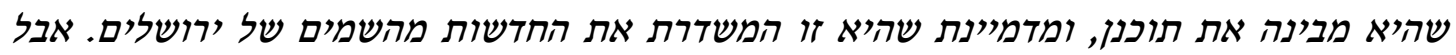

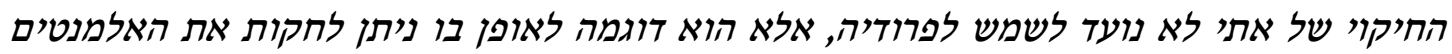

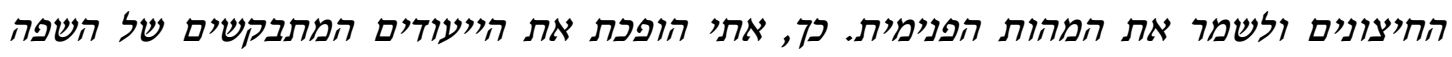
כאשר היא משתמשת בלשון הגבוהה לתאר את מה שהיא רואה סביבה.

\section{Shulamit Lir (crítica literária e ativista feminista e social). Um mundo novo} vingativo. 06 de maio de 2006.

Shiló vai contra a arrogância e vai inclinando-se a liberar os personagens dos compromissos de uma língua correta, permitindo-lhes falar no idioma do dia a dia.

A única que interioriza o hebraico elevado e polido é a filha Ety Dadón. Ety, que escuta constantemente as notícias da boca de Rahuma Eldad, repete e pronuncia as palavras "bonitas que ela diz", até que consegue entender seu significado, e imagina que ela mesma traz as notícias do céu de Jerusalém. Entretanto, a imitação de Ety não tem como fim ser uma paródia, senão que é um exemplo que demonstra que é possível imitar os elementos externos e preservar a essência interior. É assim que Ety modifica o registro da linguagem quando usa um registro elevado, descrevendo o que vê em seu entorno. 
מאמרים- רשת הפצת מאמרים מקצועיים לשימוש חופשי. כותב לא ידוע. 4 ביוני 2008.

http://www.articles.co.il/article/19822

כתיבת הספר בשפה במשלב נמוך, המאפיינת את תושבי האזור, מכניסה את הקורא, שזו אינה

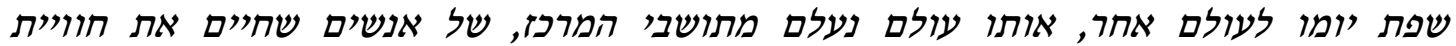
הקטיושות. אנשים עם אורח חיים אחר ודברים אחרים בראש. אנשים שחיים בצל המוות, בסכנת מוות, בפחד מוות, כל יום. השפה הדלה, בצורה מוקפדת יש לומר, יש בה כל כך הרבה כח להכניס אותך לעולם ההוא, והיא מלאת רגש, יש בה אולי איזה בוז אפילו לשפה הגבוהה של הספרות,

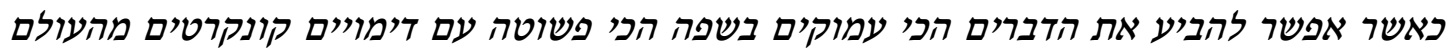
מופשטים. ולא

הפרקטי

\section{$\underline{\text { Artigos - Rede de distribuição de artigos profissionais para uso livre. Escritor }}$ anônimo. 04 de junho de 2008.}

A escrita do livro em um registro idiomático tão baixo, que caracteriza os habitantes do bairro, introduz o leitor numa linguagem que não lhe pertence, uma linguagem que pertence a um mundo de pessoas que vivem a experiência dos Katyushas (mísseis). Pessoas com um estilo de vida diferente e com outras coisas na cabeça. Pessoas que vivem à sombra da morte, todos os dias. O idioma pobre, de forma meticulosa, vale dizer, tem muita força para introduzir o leitor neste mundo e está muito cheio de sentimentos. Há, talvez, até certo desprezo pelo idioma elevado da linguagem literária, quando você pode expressar as questões mais profundas em um idioma muito simples, com imagens concretas e não abstratas do mundo prático.

\section{2- A análise geral do livro}

Como se pode notar, a crítica fala muito sobre a linguagem na qual o livro foi escrito. O fato de o livro estar escrito em um registro oral e não literário faz com que o relato seja mais verossímil, assim como gera maior confiabilidade em relação aos personagens. Entre os exemplos desta linguagem posso mencionar a troca entre 
feminino e masculino, como "shtei shekel" (dois shekel) no lugar de "shnei shkalim", "shtei yamim" (dois dias), no lugar de "yomayim"77, "shloshá peamim" (três vezes), no lugar de "shalosh peamim", "sheva elef dólar" (sete mil dólares), no lugar de "shivat alafim dolarim".

Outro fenômeno que se refere a este registro baixo é a anulação da preposição be (em), como "shavua sheavar chashavti..." (na semana passada pensei...), no lugar de "ba ${ }^{78}$ shavua sheavar chashavti", "shesh anachnu chozrim" (às seis voltamos), no lugar de "beshesh chozrim".

Aparecem também vários exemplos de articulação em lugar não correto, em casos de casos construtos $^{79}$, como "habeit sefer" (a escola), no lugar de "beit hasefer", Yehuda hu mi hamachleket tachzuká" (Yehuda é o departamento de manutenção), no lugar de "Yehuda hu mi machleket hatachzuká".

Além desses exemplos, o que dá a percepção generalizada de um registro baixo do hebraico é a presença de extraposições. Neste livro de 254 páginas, encontrei 144 extraposições, entendendo que este fenômeno faz parte desse "idioma pobre" ou da linguagem da "antinorma" à qual os críticos se referem e que a leitora quer transmitir.

De fato, quando um falante de hebraico pronuncia uma oração extraposta, é muito comum que o corrijam, já que "soa" como um falante não conhecedor da língua, que usa estruturas sintáticas que não pertencem ao hebraico espontâneo.

No primeiro capítulo, cuja protagonista é Simona Dadón, a mãe, encontrei 37 orações extrapostas, o que representa $25 \%$ do total. No segundo capítulo, de Itzik e Dudi Dadón, encontrei 65 casos, que perfazem $45 \%$ do total. No terceiro capítulo, de Kobi

\footnotetext{
${ }^{77}$ Existe em hebraico uma morfologia diferenciada para o caso de alguns substantivos que aparecem em pares. . O erro em shtei yamim é dobrado, já que por um lado yamim é um substantivo masculino e shtei é para numerar um substantivo feminino. Por outro lado, como estão falando de um par de dias, deveria aplicar-se a morfologia de paridade e assim se obteria a forma yomayim.

${ }^{78}$ Neste caso, a preposição be está acompanhando um artigo definido, portanto no lugar de be teríamos ba.

${ }^{79} \mathrm{O}$ caso construto é uma estrutura sintática, que aparece com muita frequência nas línguas semíticas. É formada, geralmente por dois substantivos ligados estreitamente entre si por um vínculo de possessão. No caso de se precisar articular esta estrutura, o artigo aparece no segundo substantivo e nunca no primeiro.
} 
Dadón, contei 33 extraposições, que são 23,5\% do total. No quarto e último capítulo, o de Ety Dadón, acontece algo bastante interessante. Ety é uma menina que tenta melhorar seu idioma pela escuta constante de notícias no rádio e imitação da locutora Rehuma Eldar. Desta maneira, Ety tenta assemelhar-se ao mundo exterior a sua casa. O curioso é que, ao ler este capítulo, é evidente que o idioma se encontra em um registro mais alto que o dos demais personagens. Basta somente verificar que, de um total de 144 orações extrapostas, há neste capítulo somente $6,5 \%$ das mesmas, ou seja, 9 orações das 144 extraposições.

Considero que este seja um bom indicador para entender quanto este fenômeno influencia no momento de se estabelecer o registro do falante.

Extraí todos os exemplos que aparecem no livro e os apresentarei neste capítulo. É necessário dizer que as orações serão escritas exatamente como aparecem no livro, isto quer dizer que os erros ortográficos não serão corrigidos. Por outro lado, a análise sintática realizada remete à análise em hebraico, isto é, poderá aparecer uma categoria sintática classificada segundo o hebraico, que não corresponde à análise em espanhol. 


\section{Exemplos de extraposição neste livro}

\section{1- Simona Dadón}

Podemos observar que a linguagem de Simona, a mãe, é mais "acidentada" do que a de seus filhos, que já nasceram em Israel. Ela somente percebe que há algo errado com seu hebraico quando alguém de fora de seu ambiente a corrige. Por exemplo, nas páginas 42 e 43, Simona conta sobre Débora, a diretora do lugar onde trabalha que vive corrigindo o hebraico, das empregadas: "Não é sheva é shivá ${ }^{80}$, não diga sinor e sim $\operatorname{sinar}^{81}$.Não quero escutar nunca mais você dizendo yoshen ${ }^{82} \ldots$ vem a facada do hebraico: sempre há um que corrige e outro que é corrigido. Se é um dos que são corrigidos, escuta o que te digo, será melhor que te sentes na trave do campo de futebol na noite em que caem os mísseis”.
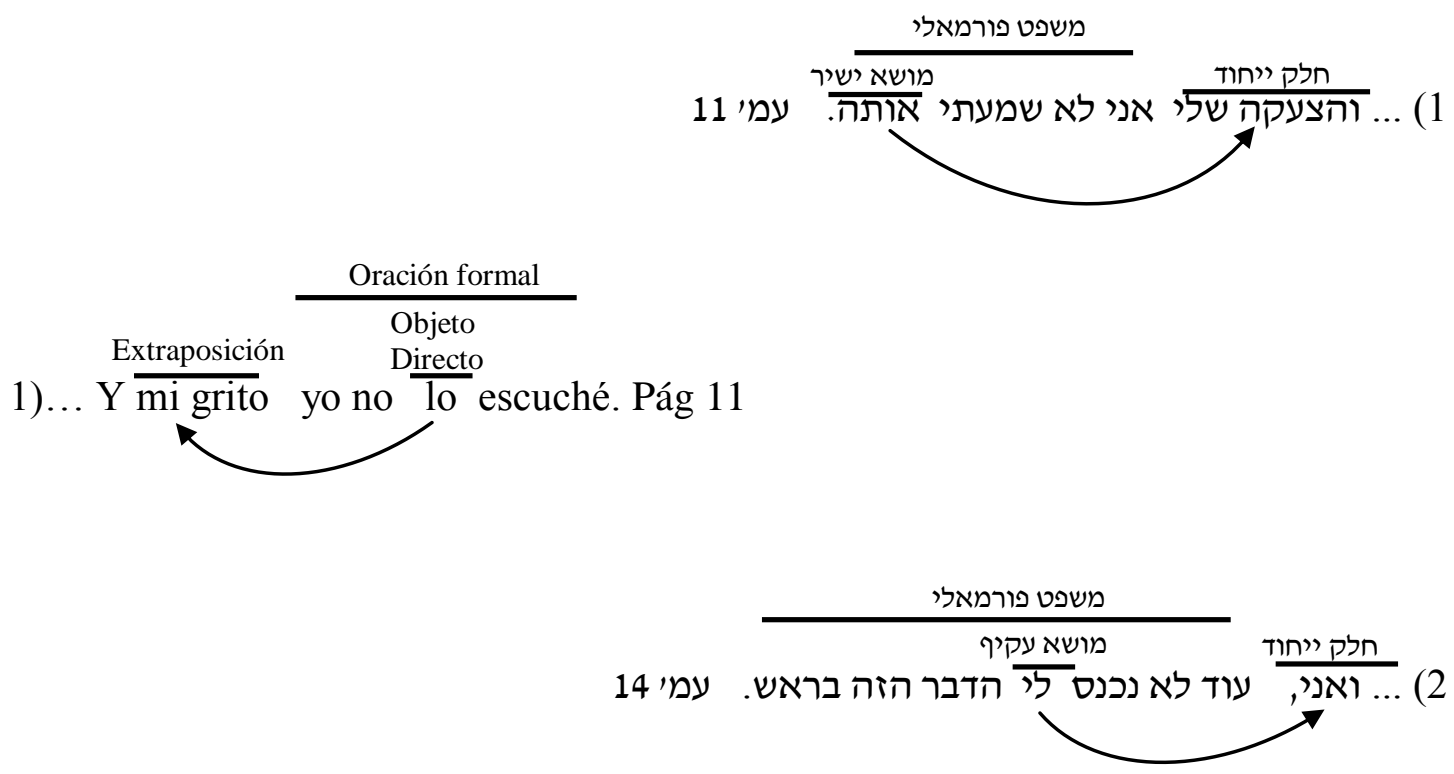

\footnotetext{
${ }^{80}$ Problema de gênero com o número sete.

${ }^{81}$ Problema morfológico referente à forma de ser dito o substantivo "avental".

${ }^{82}$ Forma não correta de dizer este verbo. Este verbo é irregular e acaba gerando uma estrutura errada por homologar-se com a morfologia padrão dos verbos em hebraico.
} 
Oración formal

Extraposición Objeto Indirecto

2)... Y yo, todavía no $\overline{m e}$ entró en la cabeza. Pág. 14

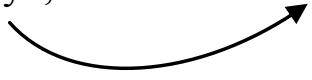

משפט פורמאלי

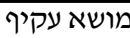

חלק ייחוד

3) ... וכל המילים שיוציאו מהפה שלהם שיתחלקו עליך, אל תיתני להם להיכנס לך לאוזניים.

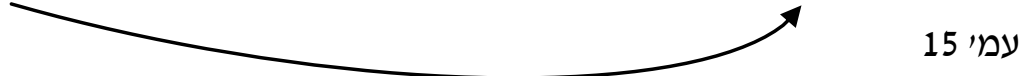

Extraposición

Objeto Indirecto

3)...Y todas las palabras que saquen de la boca de ellos y se deslicen hacia ti, no les

Oración formal

permitas entrar en tus oídos. Pág. 15.

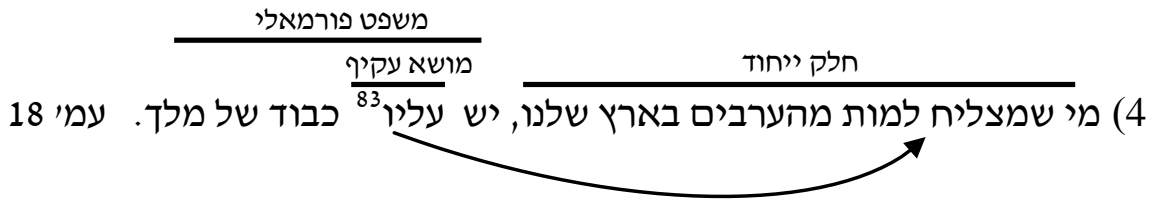

Oración formal

Extraposición

Objeto

Indirecto

4) El que consigue morir por los árabes en este país, lleva en él el honor de un rey.

Pág. 18

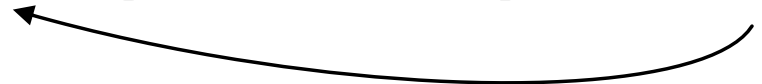

${ }^{83}$ Neste caso, estamos na presença de uma colocação lingüística que, se o pronome fosse analisado esta colocação, seria um circunstancial de lugar. 


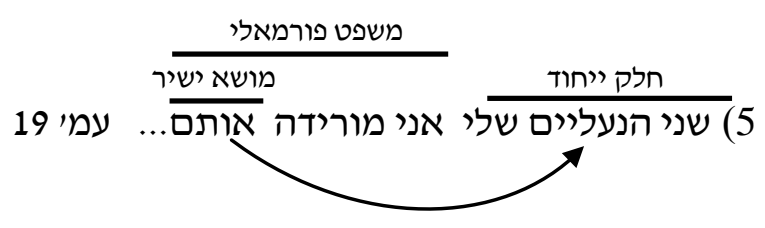

5) $\frac{\text { Extraposición }}{} } \begin{gathered}\text { Oración formal } \\ \begin{array}{c}\text { Objeto } \\ \text { directo }\end{array}\end{gathered}$ quito... Pág. 19

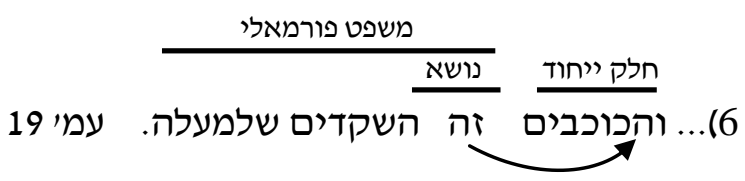

6)... y las estrellas $\frac{\text { Extraposición }}{\frac{\text { Sujeto }}{\text { ellas }} \text { son las almendras de arriba. Pág. } 19}$

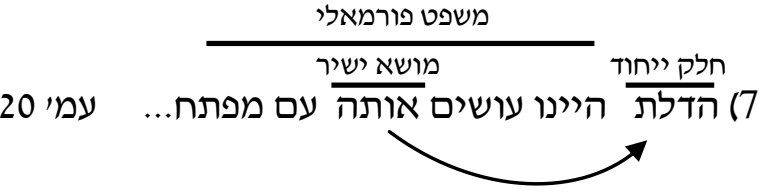

$\frac{\text { Oración formal }}{\frac{\text { Objeto }}{\text { directo }}}$ cerramos con una llave... Pág. 20




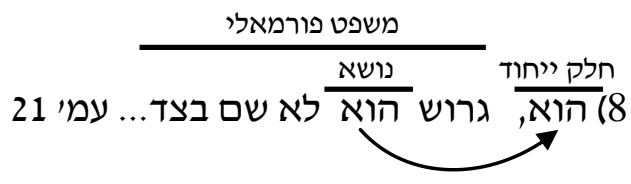

8xtraposición $\frac{\text { Oración formal }}{\stackrel{\text { Él, }}{\text { Sujeto }}}$ un peso él no deja de lado... Pág. 21

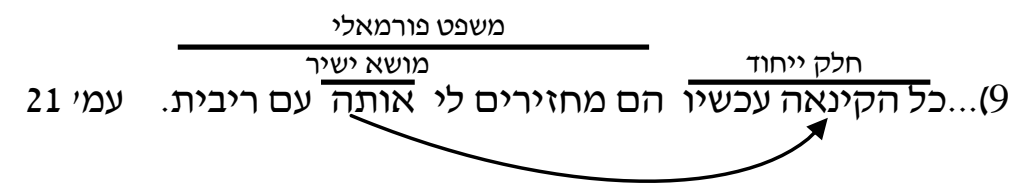

Oración formal

Extraposición

$\frac{\text { Oración formal }}{\frac{\begin{array}{l}\text { Objeto } \\ \text { directo }\end{array}}{\text { la }}}$

9)... toda la envidia ahora ellos me la devuelven con intereses. Pág. 21

r

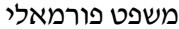

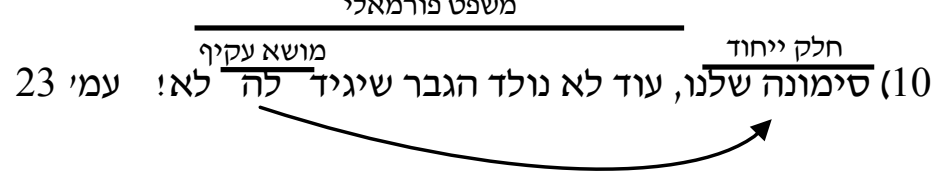

Oración formal

\begin{tabular}{ll}
\cline { 2 - 2 } Extraposición & $\begin{array}{l}\text { Objeto } \\
\text { indirecto }\end{array}$
\end{tabular}

10) Nuestra Simona, todavía no nació un hombre que le diga que no! Pág. 23

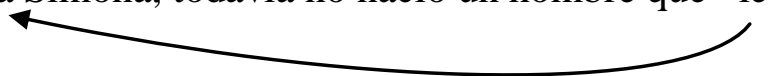




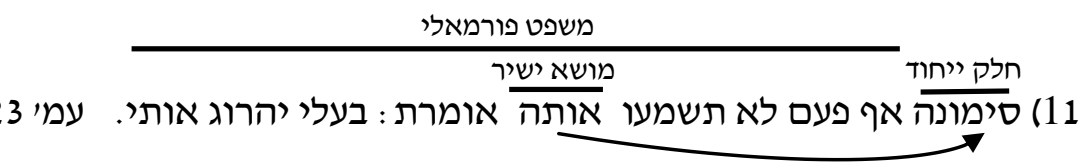

Oración formal

Extraposición $\quad \begin{aligned} & \text { Objeto } \\ & \text { directo }\end{aligned}$

11) Simona nunca la van a escuchar decir: mi marido me va a matar. Pág. 23

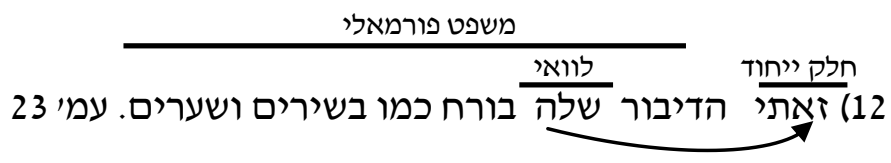

Oración formal

12) Eşa el habla de ella se escapa como las canciones y los cabellos. Pág. 23

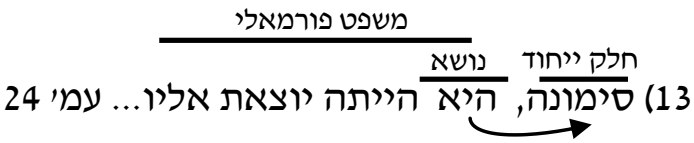

Oración formal

3) Simona, ella solía salir de él... Pág 24

$r$, en 


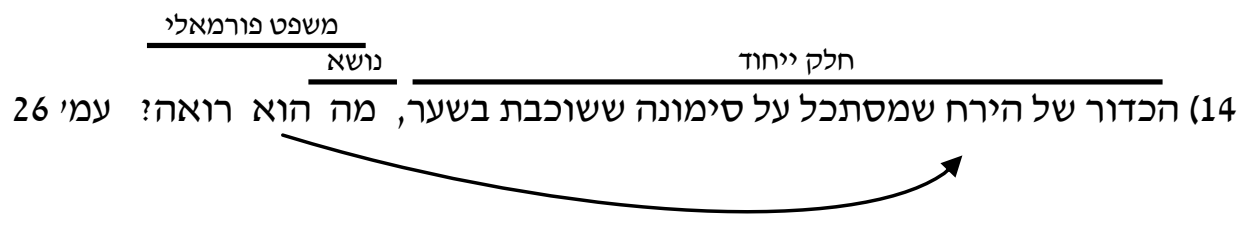

Extraposición $\quad$ Oración formal

14) $\overline{\text { La pelota de la luna que mira a Simona que está acostada en el arco, }} \overline{\text { qué ella }}$ quiere? Pág. 26

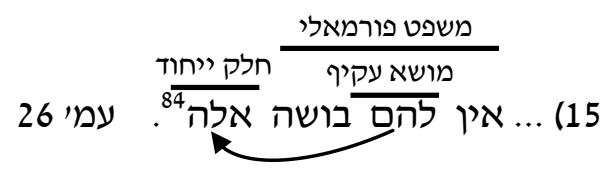

15)... no $\frac{\text { Oración formal }}{\text { Objeto }} \stackrel{\text { indirecto }}{\text { les da vergüenza a estos. Pág. } 26}$

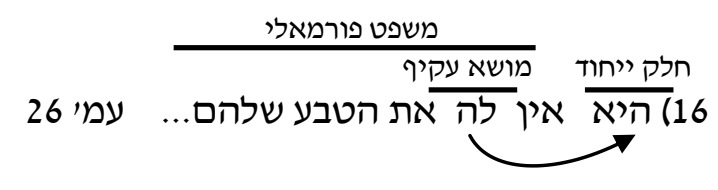

Extraposición Objeto

Objeto $\quad$ Oración formal

16) Ella, ella no tiene la naturaleza de ellos... Pág. 26

${ }^{84}$ Neste caso, a extraposição se localiza no final e não no começo da oração. 


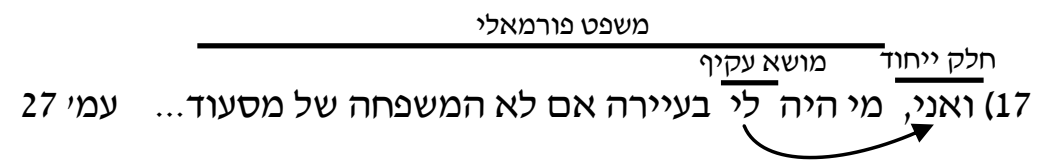

Oración formal

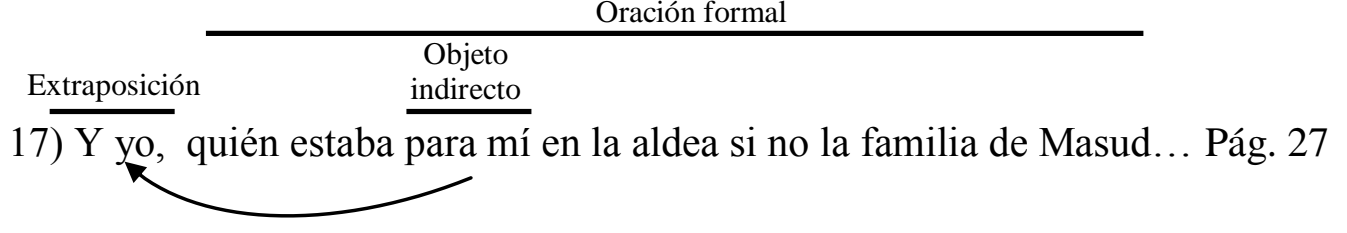

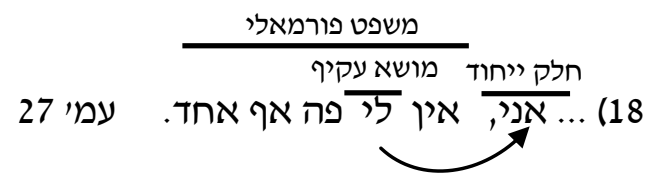

\begin{tabular}{cc} 
& Oración formal \\
\cline { 2 - 2 } Extraposición & $\begin{array}{c}\text { Objeto } \\
\text { indirecto }\end{array}$
\end{tabular}

18)... Уo, no tengo para mí acá a nadie. Pág. 27
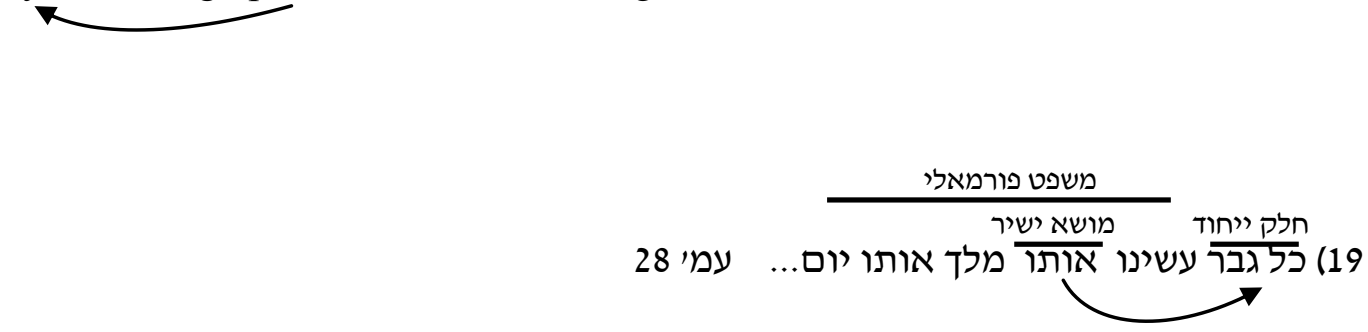

Oración formal

Extraposición Objeto

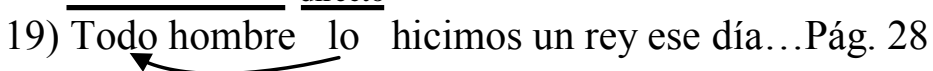




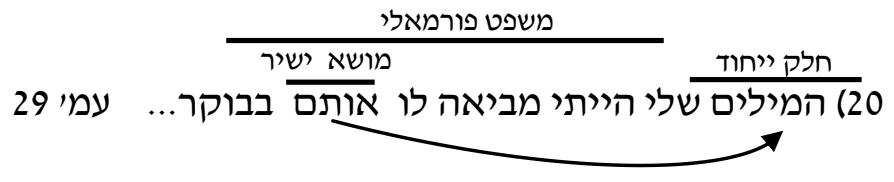

Oración formal

Extraposición directo

20) Mis palabras $\frac{\text { las }}{\gtrless}$ solía traerlas por la mañana... Pág 29

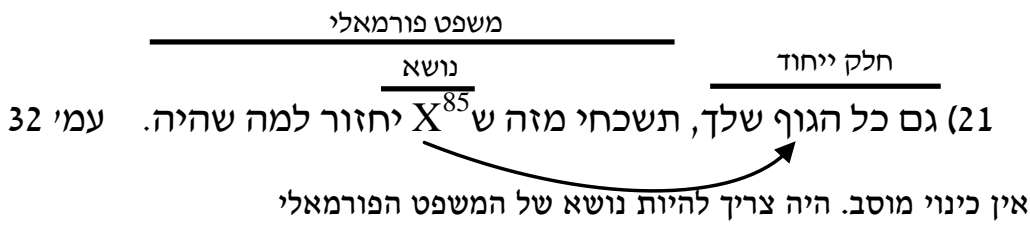

21) También todo tu cuerpo olvídese que vuelva a lo que era. Pág. 32

Extraposición sin huella. Debería ser el sujeto de la oración formal.

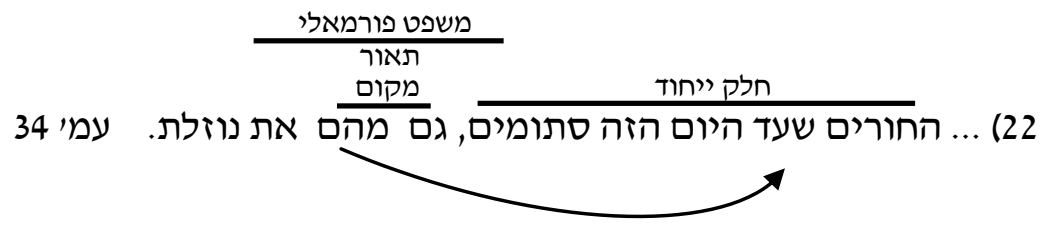

${ }^{85}$ A coindexação é uma categoria vazia. 


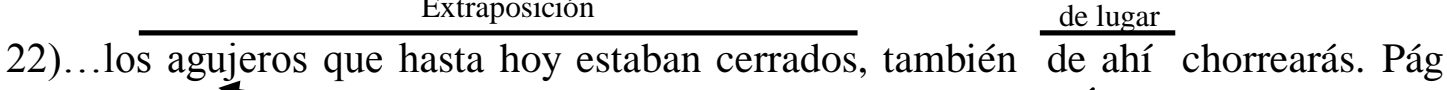
34.

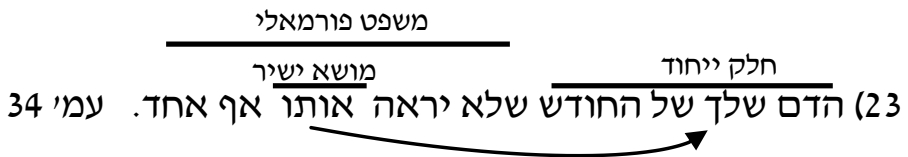

\begin{tabular}{cc}
$n$ & Oración formal \\
\cline { 3 - 3 } Extraposición & $\begin{array}{l}\text { Objeto } \\
\text { directo }\end{array}$
\end{tabular}

23) La sangre tuya del mes que no la vea nadie. Pág 34

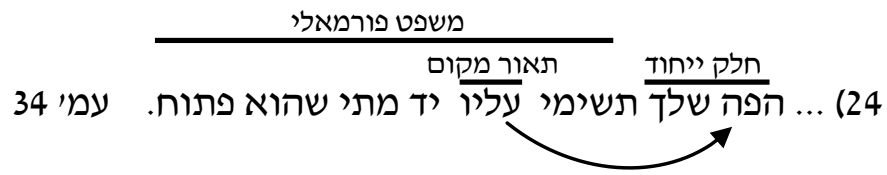

Oración formal

Extraposición de lugar

Circunstancial

24)... $\overline{\text { tu boca }}$ pon $\overline{\text { sobre ella }}$ una mano cuando quede abierta. Pág 34
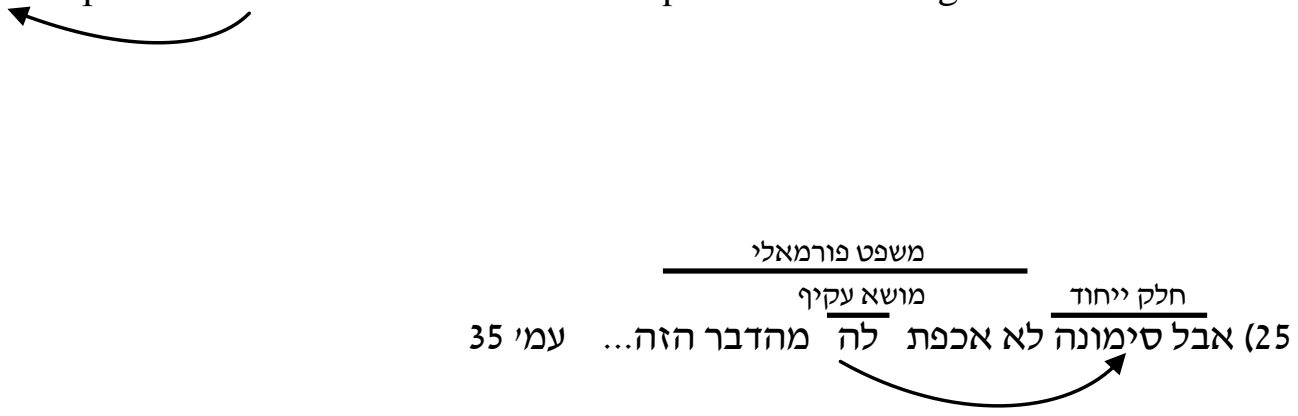


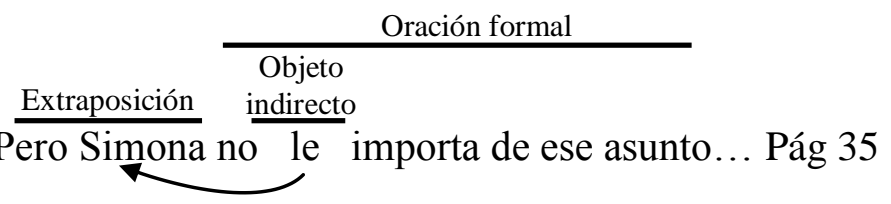

משפט פורמאלי

מושא עקיף

חלק ייחוד

26) אפילו קובי,, בזמן האחרון בורחים לודי העינים מתי שרואה אותי. עמי 35

Oración formal

Objeto

Extraposición

indirecto

26) Inclusive Koby, en el último tiempo se le escapan los ojos cuando me ve. Pág.

35

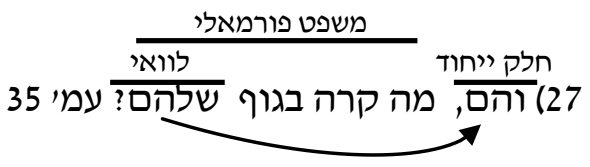

משפט פורמאלי

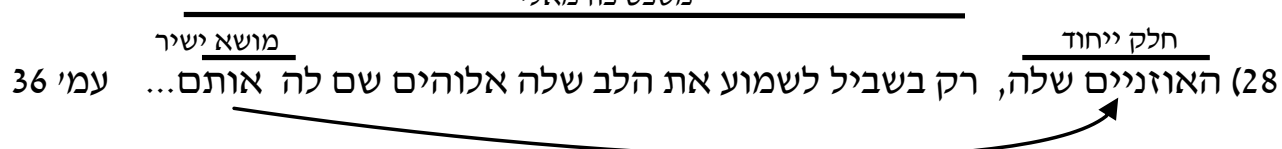

Oración forma

Objeto

Extraposición

directo

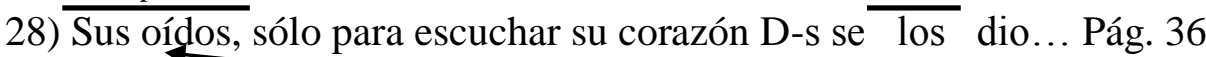




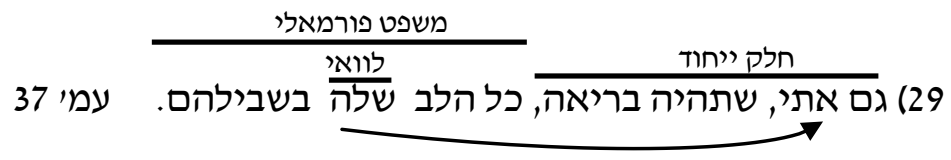

Oración formal

Modificador

Extraposición

directo

29) También Ety, que sea sana, todo el corazón $\overline{\text { de ella }}$ es para ellos. Pág. 37

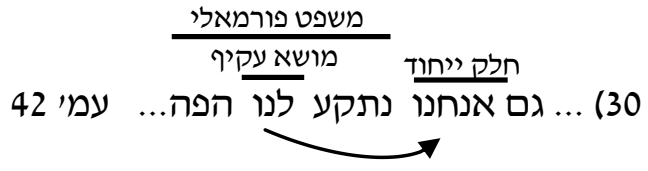

30)... también nosotros se $\frac{\text { Extraposición }}{\frac{\text { Objeto }}{\text { indirecto }}}$

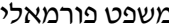

\begin{tabular}{|c|c|c|c|c|}
\hline & & לוואי & & 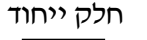 \\
\hline 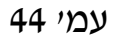 & נהיות מצלמה. & שלה & איך שהיא פותחת את הדלת של המעון, העיניים ' & 31) היא, \\
\hline
\end{tabular}

Oración formal

Modificador

Extraposición

directo

31) Ella $a_{\leftarrow}$ en cuanto ella abre la puerta del jardín, los ojos $\overline{\text { de ella }}$ son una cámara.

Pág. 44 


32) .... אלקי, מוד מה יש לאי מהשם של מי ייכנס בארגז שלהם יותר הרבה פעמים. עמ' 53

Oración formal

Extraposición

$\frac{\text { Oración formal }}{\begin{array}{c}\text { Objeto } \\ \text { indirecto }\end{array}}$

32) $\overline{\ldots \text { Yo, }}$ que tengo para mí del nombre que ingresan en su urna más veces? Pág. 53 $\gamma^{2}$

משפט פורמאלי

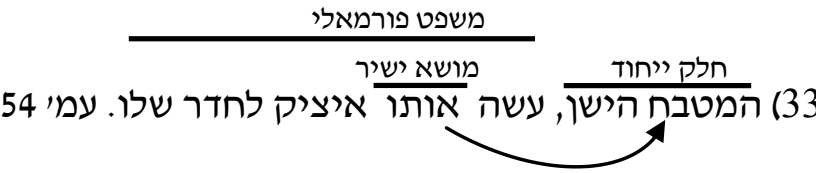

Oración formal

Objeto

directo

33) La antigua cocina, la transformó Itzik en su cuarto. Pág. 54

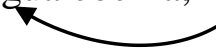

7 transformó Itzik en su cuarto. Pág. 54

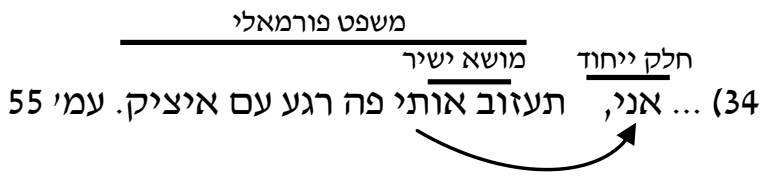

Oración formal

34)... Y Yo, dejame acá un segundo con Itzik. Pág 55. 


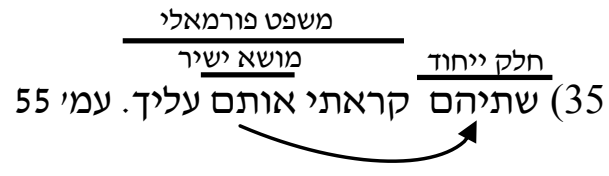

$\frac{\text { Oración formal }}{\text { Objeto }}$

Extraposición directo

35) $\underset{\text { Los dos }}{\operatorname{los}}$ llame como vos. Pág 55.

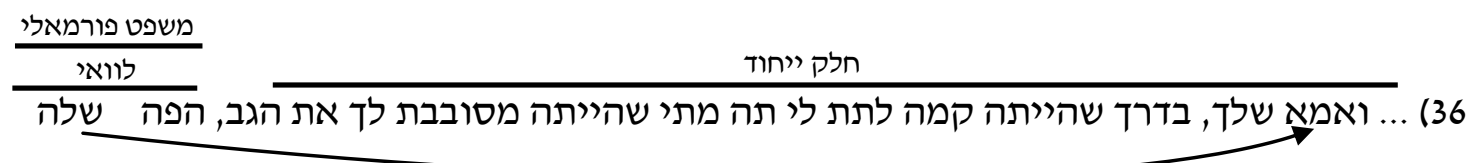

לא מוציא את מה שהיא חושבת... עמי 58

Extraposición

$\overline{\text { M. directo }}$

36)... y tu madre, en cuanto se levantaba a darme un té cuando te daba la espalda, su

Oración formal

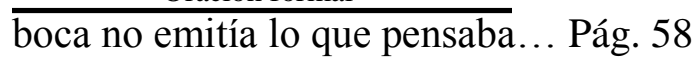

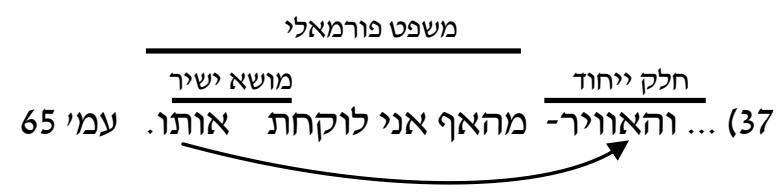

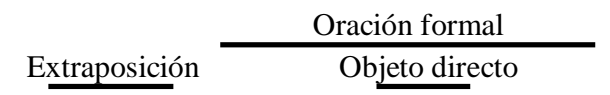

37)... y el aire- de la nariz lo agarro. Pág. 65 


\section{2- Dudi e Yitzik Dadón}

Este é o segundo monólogo que aparece no livro. Dudi e Yitzik são irmãos gêmeos, os menores da família. Dudi é, dos dois, o irmão centrado e pensante, enquanto Yitzik é o enlouquecido e rebelde. Durante o relato, vai-se descobrindo que Yitzik possui um problema físico de nascença - os dedos de suas mãos não cresceram bem. Parecer ser essa a causa pela qual Yitzik está sempre no limite entre a travessura e a falta de interesse nele mesmo. Dudi, por outro lado, sente necessidade de cuidar dele e protegê-lo. Pelos dos olhos de Dudi podemos apreciar a imagem estrutural da casa e da família. A casa é composta de dois apartamentos que foram unidos Yitzik decidiu dormir na antiga e pequena cozinha, adestrando um falcão com o objetivo de protegêlos de possíveis ataques terroristas.

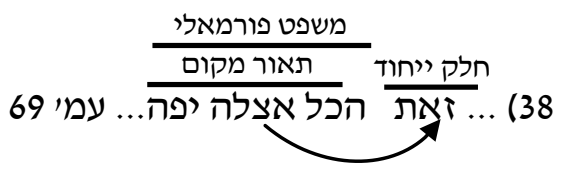

\footnotetext{
Oración formal

Circunstancial

Extraposición de lugar

38)... esa todo en ella es lindo... Pág. 69
}

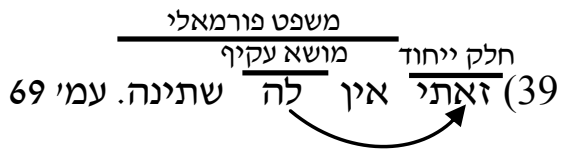


39) $\frac{\text { Extraposición }}{\text { Esta, no tiene } \frac{\text { Objeto indirecto }}{X} \text { orina. Pág. } 69}$

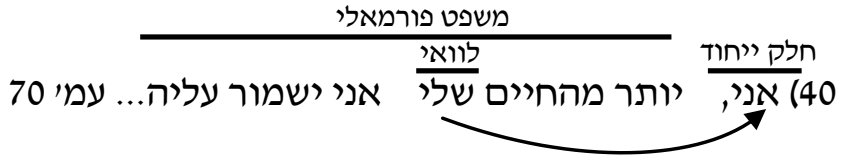

Oración formal

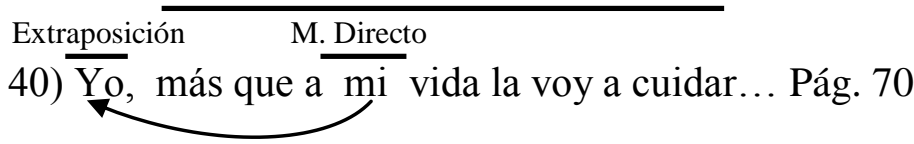

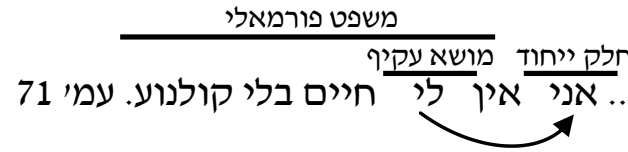

Oración formal

Extraposición Objeto indirecto

41)... yo no hay vida para mí sin el cine. Pág. 71

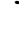

par. 71

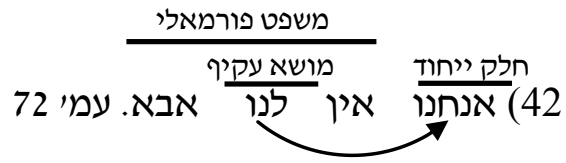



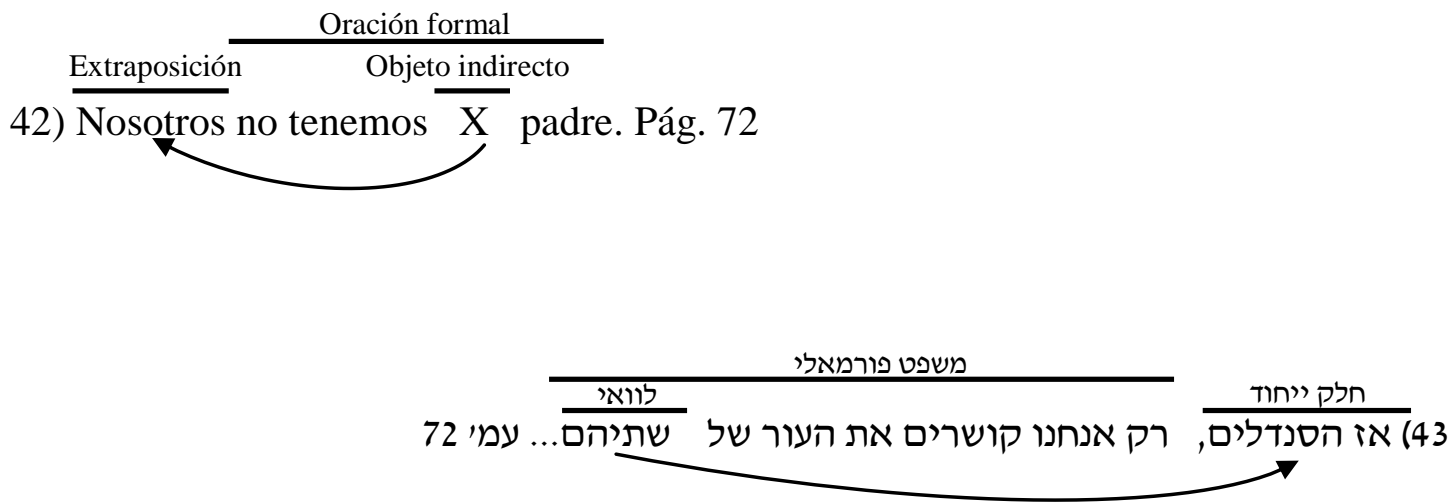

Extraposición $\quad$ Oración formal

43) Las sandalias, sólo nosotros atamos el cuero de las dos. Pág. 72

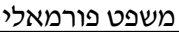

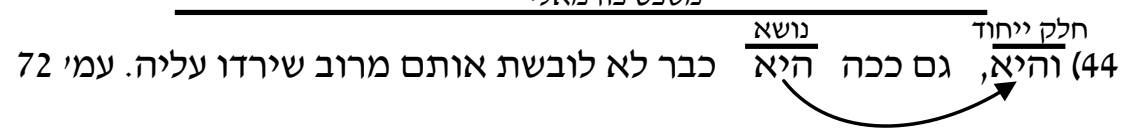

Oración formal

Extraposición Sujeto

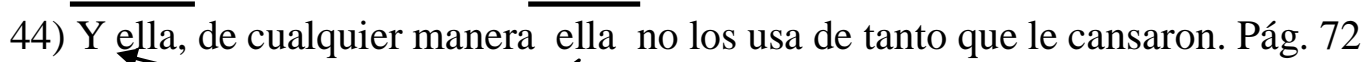

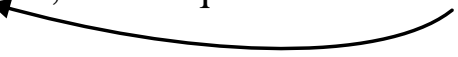

משפט פורמאלי - (שאי

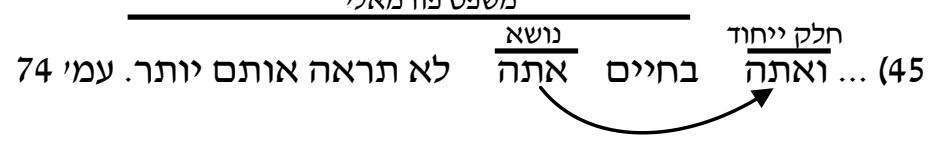

Oración formal

Extraposición Sujeto

45)... y tú en tu vida tú no los verás más. Pág. 74 


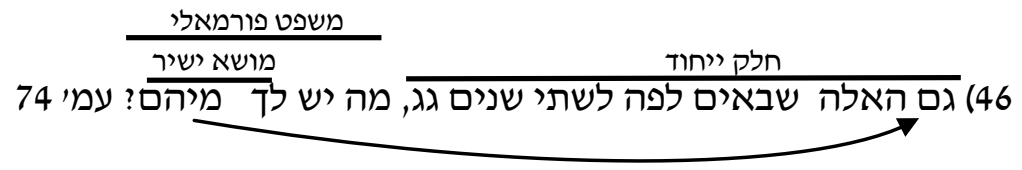

Oración formal

Extraposición

Objeto directo

46) También ellos que vienen por dos años a lo sumo, que tenés con ellos? Pág. 74

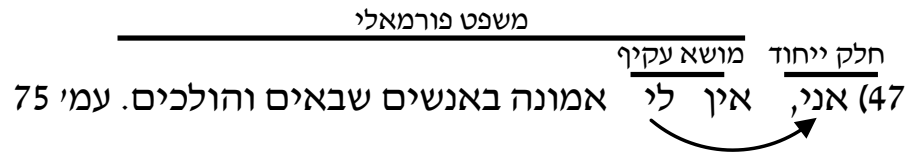

Oración formal

Extraposición Objeto indirecto

47) Yo no tengo $X$ fe en las personas que vienen y se van. Pág 75

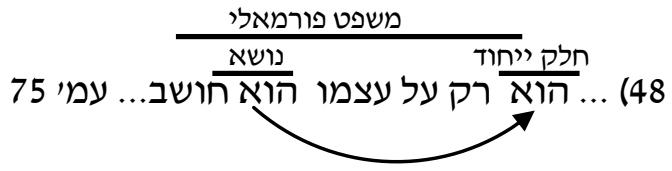

48)...él sólo en él piensa... Pág. 75 


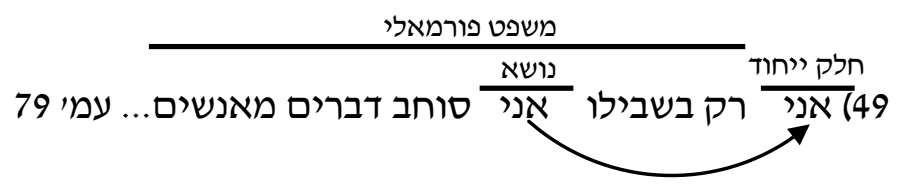

Oración formal

Extraposición Sujeto

49) $\overline{Y_{0}}$ sólo por él yo me llevo cosas de la gente... Pág. 79

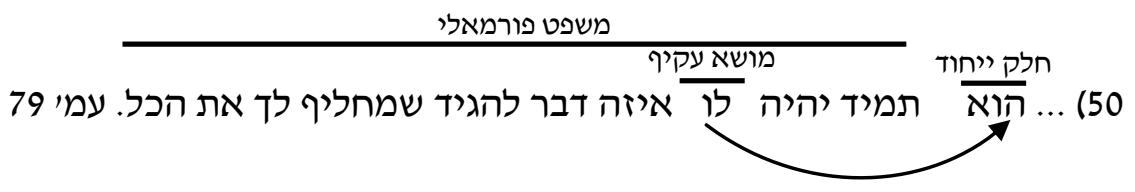

Oración formal

Extraposición
$\begin{aligned} & \text { Objeto indirecto } \\ & 79\end{aligned}$.él siempre va a tener $\frac{\mathrm{X}}{\mathrm{X}}$ alguna cosa qué decir para cambiarte las cosas. Pág.
79

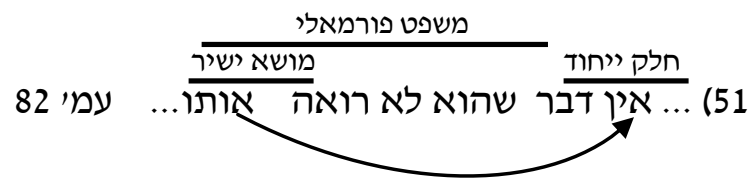

51)... no hay nada que él no lo vea... Pág 82 


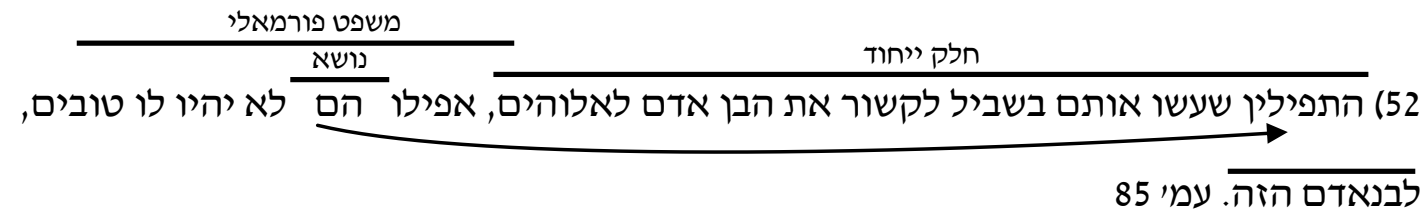

Extraposición

Oración formal Sujeto

52) Los tefilín que fueron hechos para atar al hombre a Dios, incluso ellos no son

buenos para una persona así. Pág 85

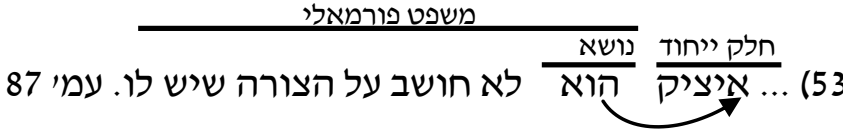

Oración formal

Extraposición Sujeto

53)...itzik él no piensa sobre la forma que tiene. Pág. 87

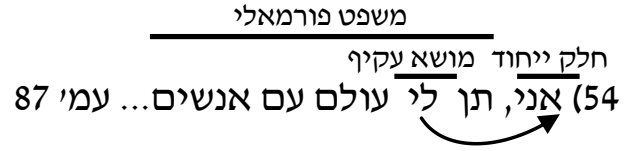

Oración formal

Extraposición Objeto indirecto

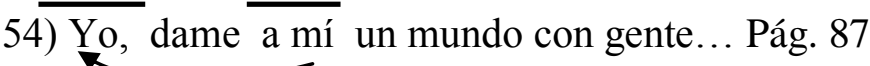


פסוקית מושא

נושא

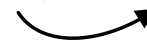

Subordinante de objeto directo

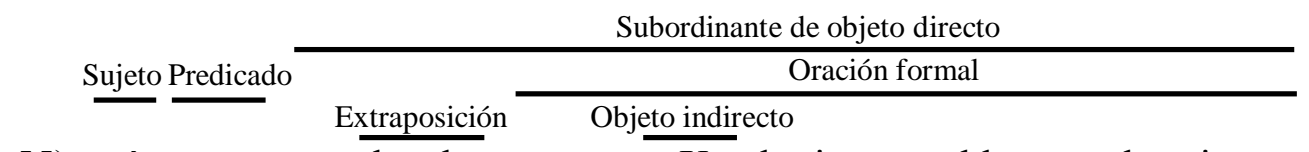

55)...tú crees que $\overline{\operatorname{los} \text { dos }}$ tenemos $\mathrm{X}$ el mismo problema en las piernas. Pág 88

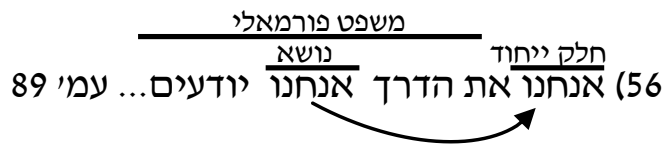

Extraposición $\frac{\text { Oración formal }}{$\cline { 2 - 2 }}

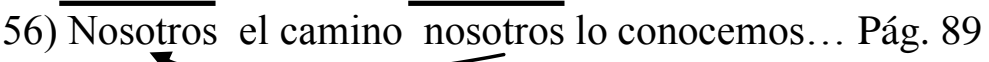

$r$ r

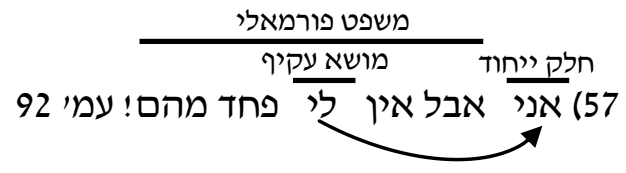

Oración formal

Extraposición Objeto indirecto

57) $\overline{Y_{0}}$ pero no tengo $\bar{X}$ miedo de ellos! Pág. 92 


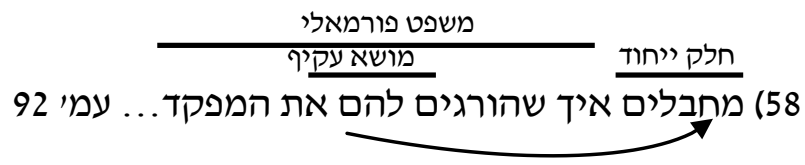

Oración formal

Extraposición Objeto indirecto

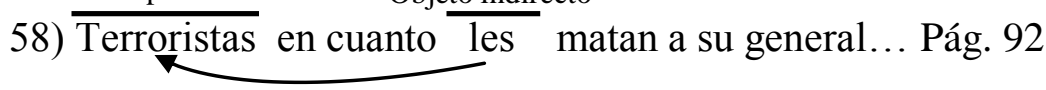

Oración formal

Extraposición Objeto indirecto

59) sólo que ella carga en ella mucho respeto. Pág. 94

משפט פורמאלי

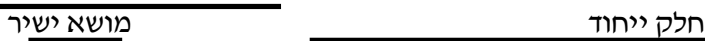

60) כל מחשבה שיוצאת מהראש של איציק, אתה רואה אותה אחרי שתיים- שלוש ימים... עמ' 95

Oración formal

Extraposición

Objeto directo

60) Todo pensamiento que sale de la cabeza de Itzik, lo puedes ver después de dos $\mathrm{O}$

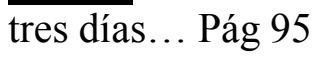




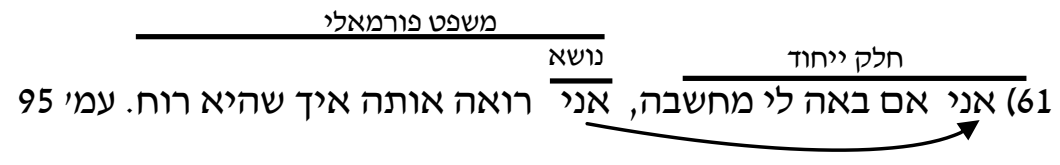

Oración formal

Extraposición Sujeto

61) $\overline{\text { Yo si me viene un pensamiento, }} \overline{\text { yo }}$ lo veo como si fuese viento. Pág. 95

משפט פורמאלי

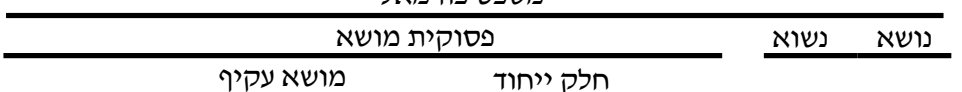

62) ... אתה רואה שכל משפחה של שערות יש להם אוד את הצד שלהם. עמי 99

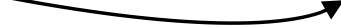

Oración formal

Subordinada objeto directo

Sujeto Predicado $\quad$ Extraposición Objeto indirecto

62) Tú ves que toda familia de cabellos tienen $\mathrm{X}$ su propia dirección. Pág.

99
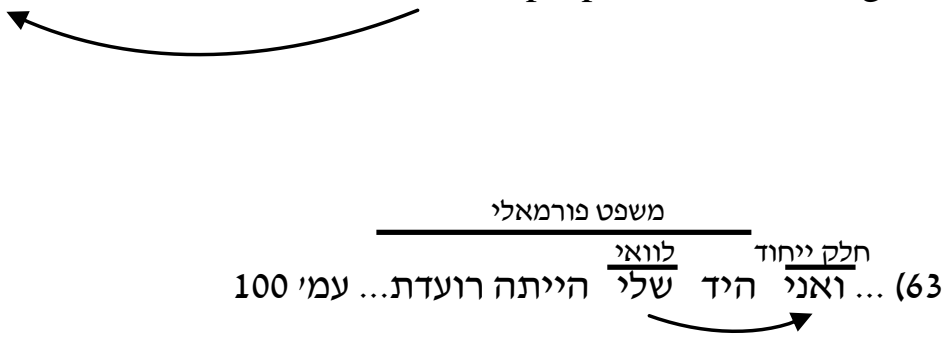

Extraposición M. directo

63)...у yo $\overline{\mathrm{mi}}$ mano temblaba... Pág. 100 


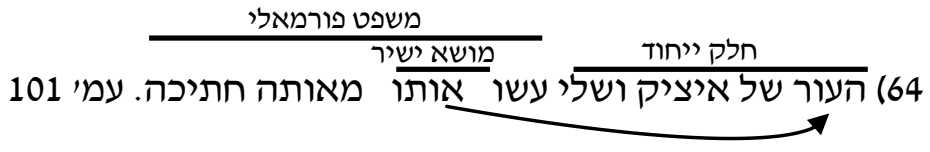

Oración formal

Extraposición Objeto directo

64) La piel de Itzik y mía lo hicieron del mismo pedazo. Pág. 101

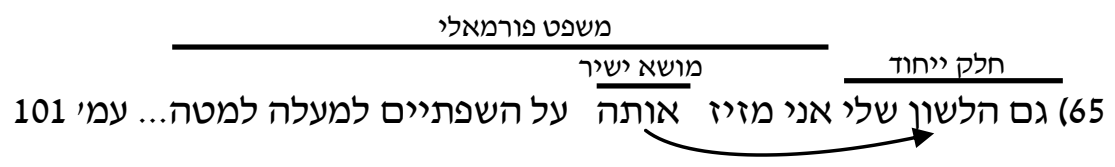

Oración formal

Extraposición Objeto directo

65) También mi lengua yo la muevo sobre mis labios hacia arriba y abajo... Pág.

101

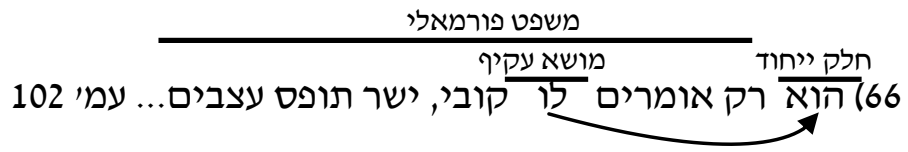

Oración formal

Extraposición Objeto indirecto

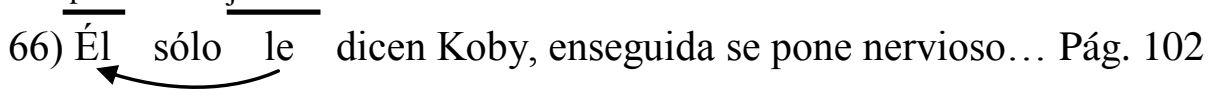




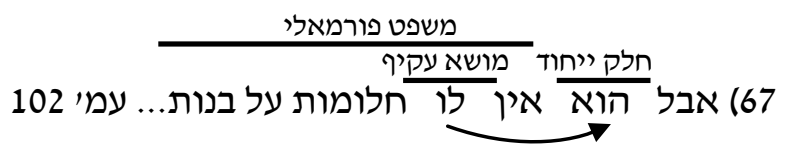

Oración formal

Extraposición Objeto indirecto

67) Pero él no tiene $\bar{X}$ sueños con mujeres... Pág. 102

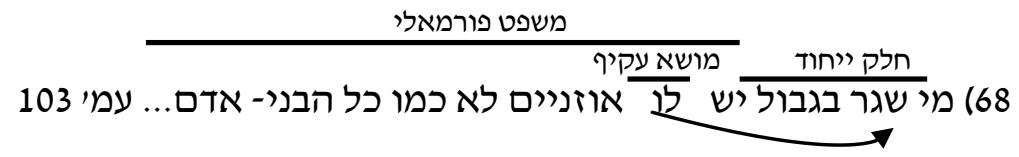

Oración formal

Extraposición

Objeto indirecto

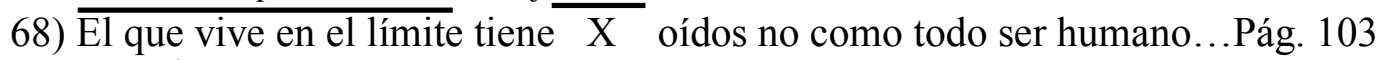
$r$

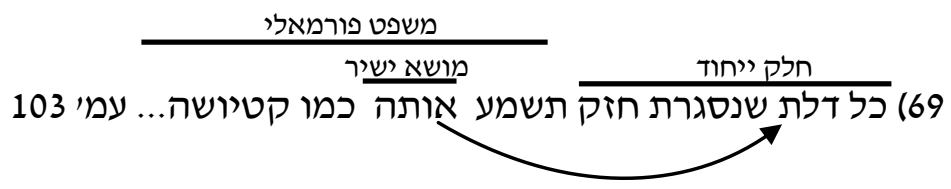

Extraposición

Oración formal

Objeto directo

69) Toda puerta que se cierra fuerte la vas a oír como un misil...Pág. 103 


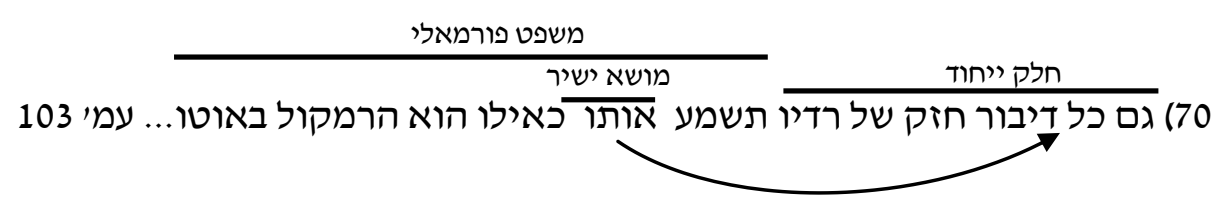

Oración formal

Extraposición

Objeto directo

70) También toda voz de la radio la escucharás como un parlante de auto...Pág.

103

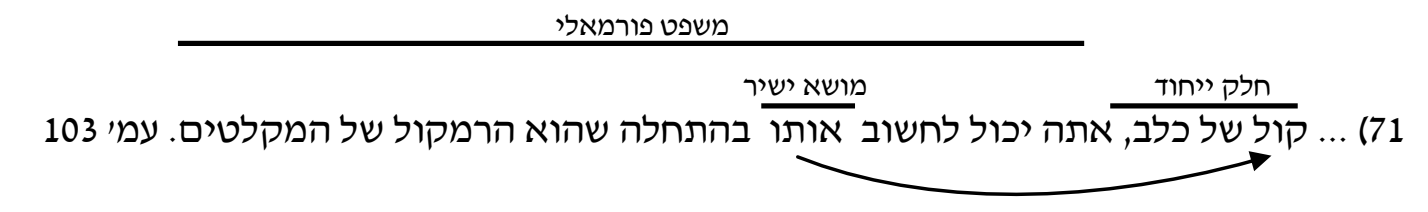

Extraposición $\quad$ Oración formal

71)... la voz de un perro, tú $\overline{\text { la }}$ puedes percibir como un parlante de un auto. Pág. 103

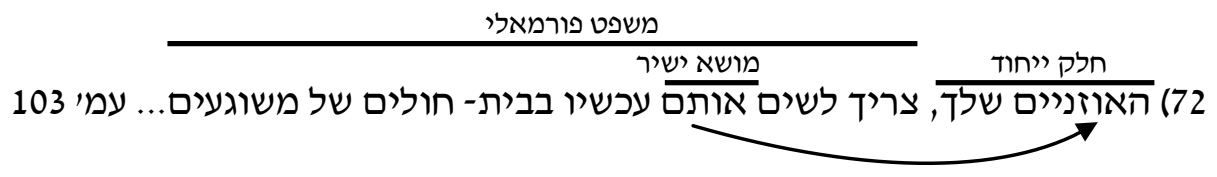

Oración formal

Extraposición Objeto directo

72) Tus oídos, habría que ponerlos ahora en un manicomio...Pág. 103 


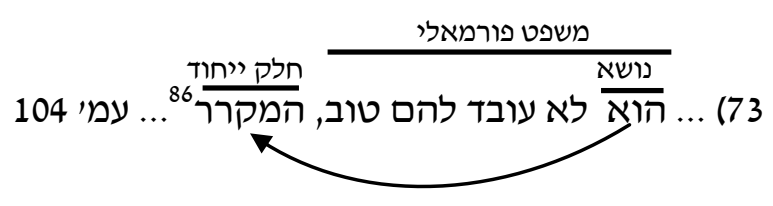

73)...Él no les funciona bien, la heladera...Pág. 104

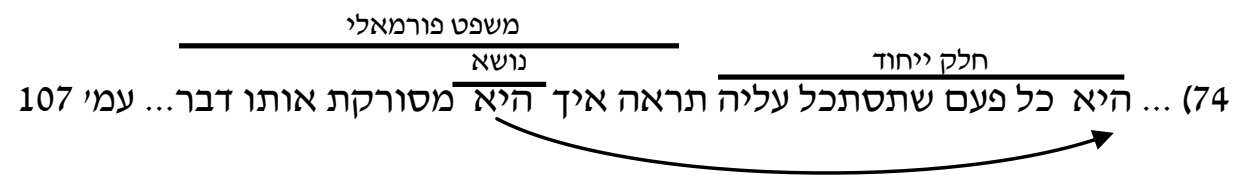

Oración formal

Extraposición Sujeto

74)...ella cada vez que la observes verás como ella está peinada igual...Pág. 107

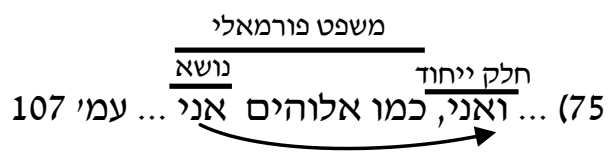

${ }^{86}$ Neste caso, a extraposição se localizn ao final da oração. 


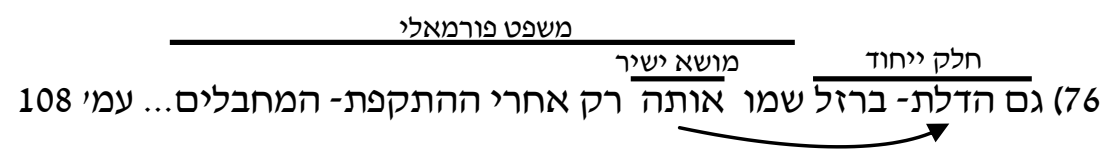

Oración formal

Extraposición Objeto directo

76) También la puerta de hierro la pusieron sólo después del ataque terrorista...

Pág. 108

משפט פורמאלי

מושא עקיף

חלק ייחוד

77) שש נפשות כמו שהיה לנו מתי שאבא היה בחיים, מזמן היה צריך לתת לנו עוד חמישים ושש

109 מטר...

Extraposición

Oración formal

Objeto indirecto

77) Seis almas como era cuando papá vivía, hace tiempo nos tendrían que haber

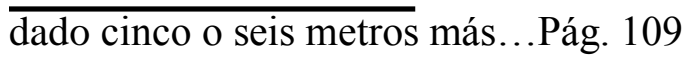

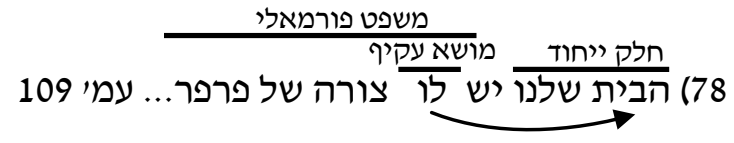

Oración formal

Extraposición Objeto indirecto

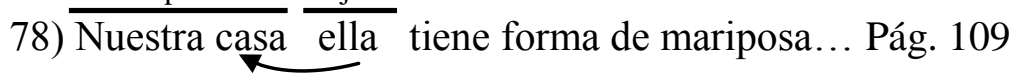




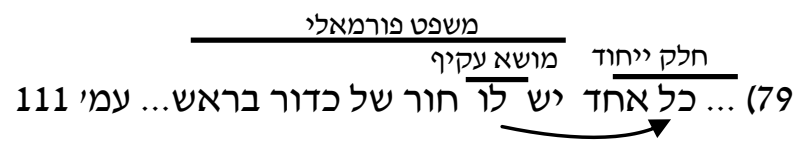

79)...cada uno $\frac{\text { Extraposición }}{$\cline { 3 - 3 }} tiene $\frac{\text { Objeto indirecto }}{\text { en él }}$ un agujero de bala en la cabeza...Pág. 111

משפט פורמאלי

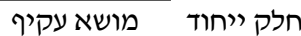

80) ... שהנמלה אין לה את את הפחד של המלחמות. עמ' 112

80)... que la hormiga no tiene miedo $\frac{\text { Obación formal }}{\mathrm{X}}$ de las guerras. Pág. 112

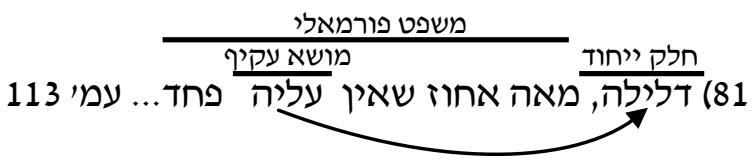

Extraposición Objeto indirecto

81) Dalila, cien por ciento que no hay en ella miedo...Pág. 113 


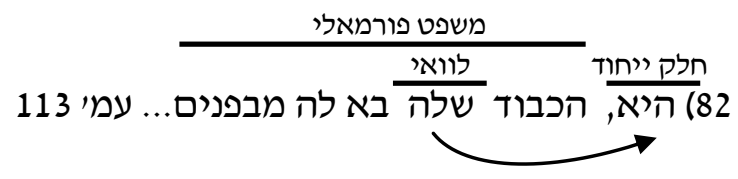

Oración formal

Extraposición $\quad$ M. directo

82) Ella, el respeto de ella viene de adentro...Pág. 113

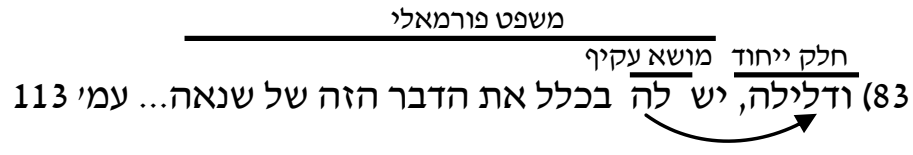

Oración formal

Extraposición Objeto indirecto

83) Y Dalila, no tiene con ella eso del odio...Pág. 113

k , no tiene con ella

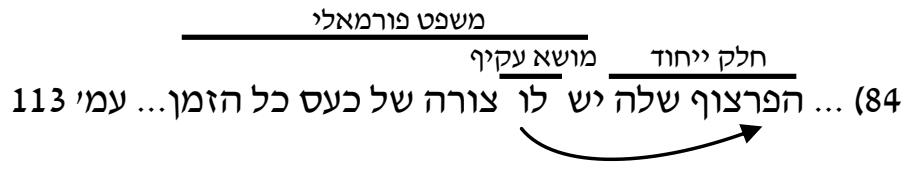

Oración formal

Extraposición Objeto indirecto

84)...su cara tiene $X$ forma de enojo todo el tiempo...Pág. 113 


\section{Oración formal}

Extraposición Objeto indirecto

85) Dalila tiene X su respeto. Pág. 114

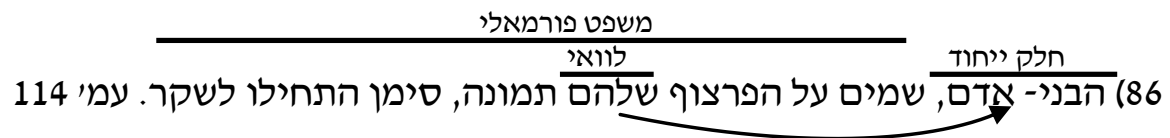

Oración formal

86) $\frac{\text { Extraposición }}{\text { Los humanos, ponen en sus }}$ caras una foto, significa que están mintiendo. Pág.

משפט פורמאלי

87 ד־לילה, הייחוד הושא גם לא תשאל אותך מה שלומך... עמ' 114

Oración formal

Extraposición Sujeto

87) $\overline{\text { Dalila, }} \overline{\text { ella }}$ tampoco te pregunta cómo estás... Pág. 114 


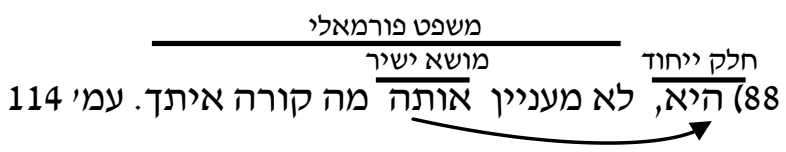

Oración formal

Extraposición Objeto directo

88) Ella, no $\overline{\text { le }}$ interesa lo que te pasa. Pág. 114

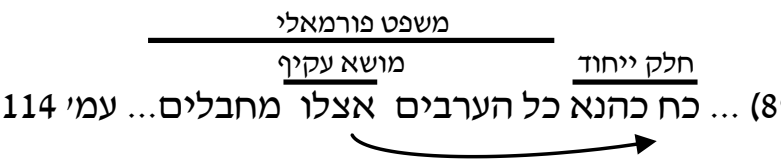

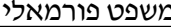

89 ... כח כהנא כל הערבים אצלו מחבלים... עמ' 114

Extraposición Objeto indirecto

89)... $\overline{\text { la fuerza de Kahana }}$ todos los árabes $\overline{\text { para él }}$ son terroristas...Pág. 114

R

משפט פורמאלי

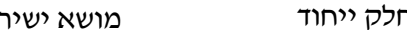

90) הקם, אני לא רואה אותם מורידים את הפצצות... עמי 119

Oración formal

Extraposición Objeto directo

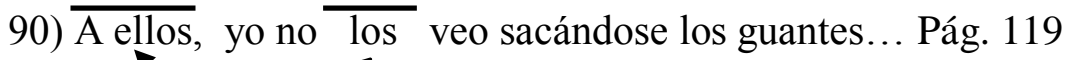




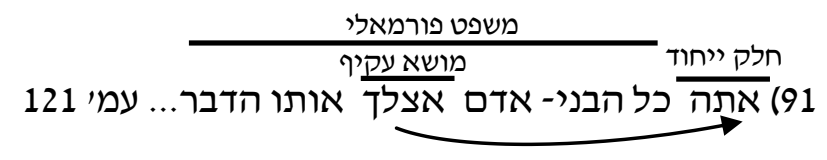

Oración formal

Extraposición Objeto directo

91) Tú todo ser humano para tí es la misma cosa...Pág. 121

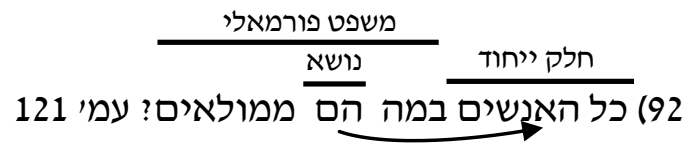

Oración formal

92) Todos los hombres de qué $\frac{\text { Sujeto }}{\text { ellos }}$ están rellenos? Pág. 121

משפט פורמאלי

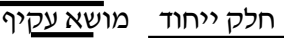

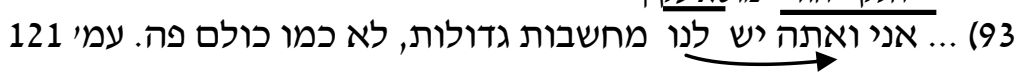

Oración formal

Extraposición Objeto indirecto

93) Tú y yo tenemos nosotros grandes pensamientos, no como todos aquí. Pág. 121

משפט פורמאלי

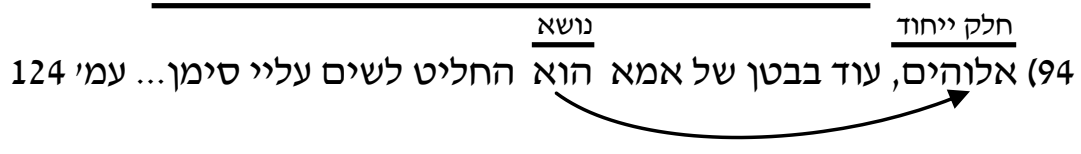


Oración formal

Extraposición Sujeto

94) $\overline{\text { Dios, }}$ ya desde la panza de mi mamá él decidió ponerme un símbolo... Pág. 124

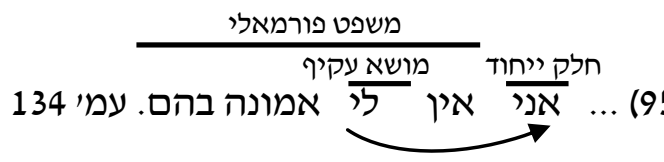

Oración formal

Extraposición Objeto indirecto

95)... 选 no tengo $X$ fe en ellos. Pág. 134

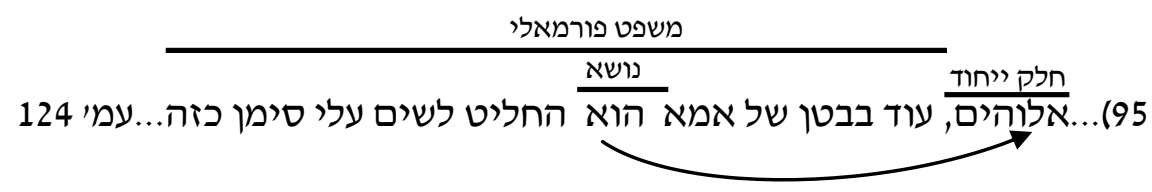

Oración formal

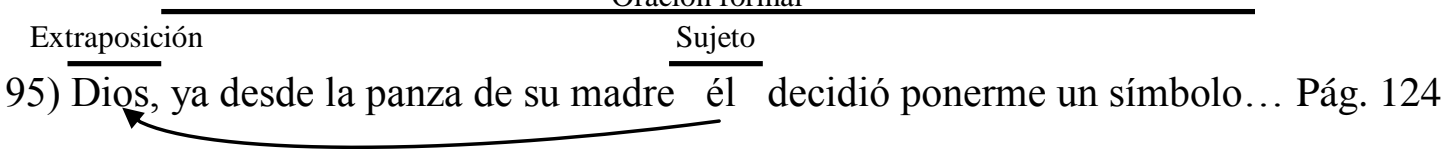

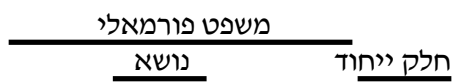

96...אנחנו גם בחלום אנחנו ביחד? עמי 125

Oración formal

Extraposición Sujeto

96)... 


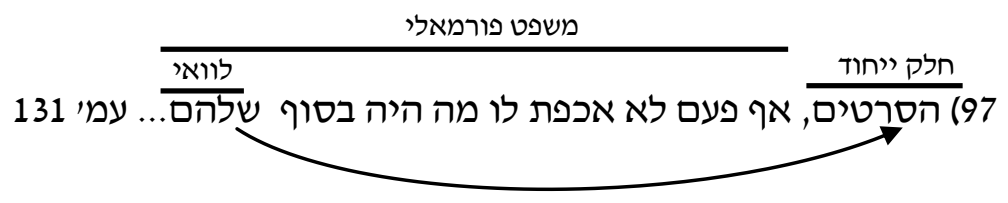

Oración formal

\begin{tabular}{cc} 
Extraposición & $\begin{array}{c}\text { Modificador } \\
\text { directo }\end{array}$ \\
\hline das
\end{tabular}

97) Las películas, nunca le importa cuál era el final de ellas... Pág. 131

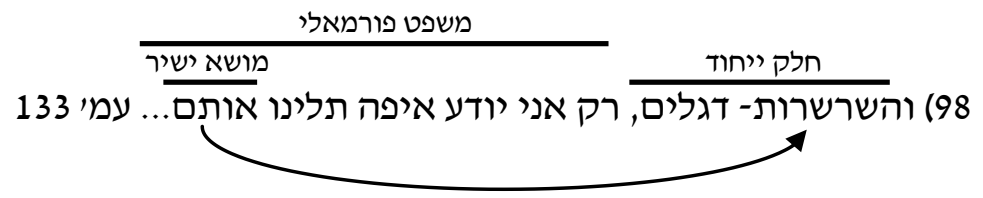

Objeto directo

98) Y la cadena de banderas, sólo yo sé donde las $\operatorname{colgamos...~Pág.~} 133$
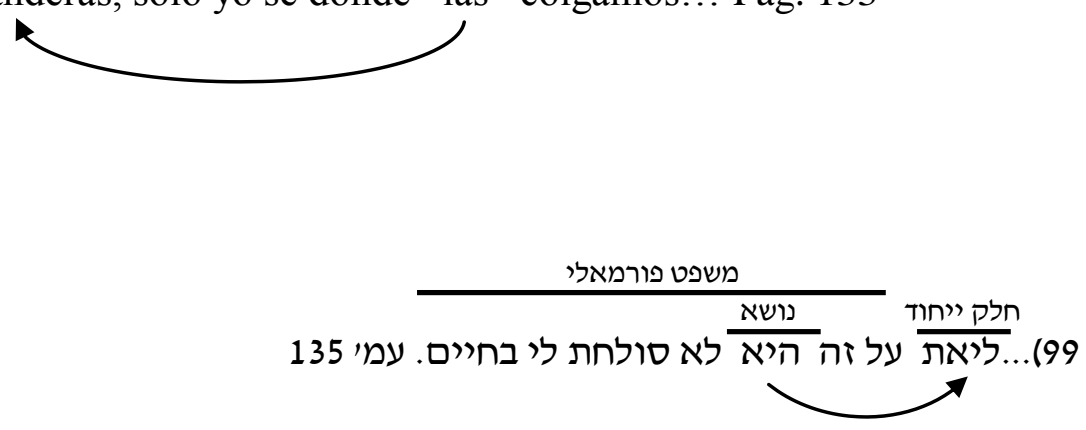

Oración formal

Extraposición Sujeto

99)...Liat sobre eso $\frac{\text { Sujeto }}{\text { ella }}$ no me perdona en la vida. Pág. 135 


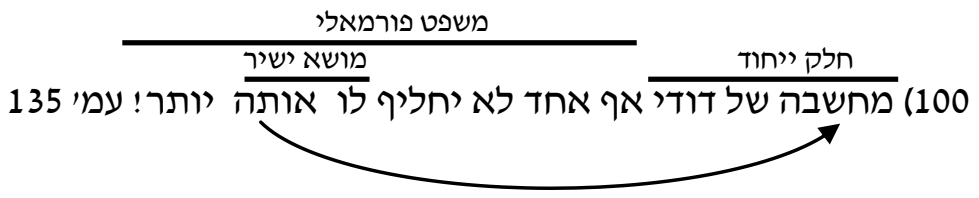

Oración formal

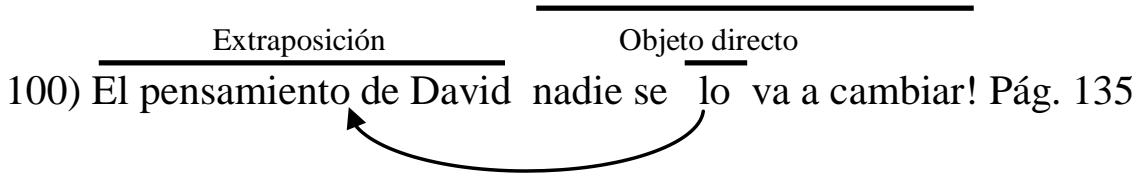

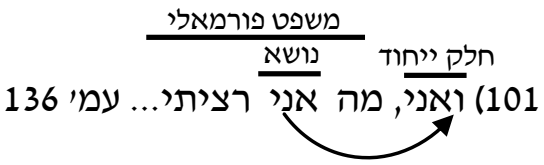

101) $\frac{\text { Sujeto }}{\mathrm{Y} \text { yo, que }} \frac{\text { Extraposición }}{\text { Oración formal }}$

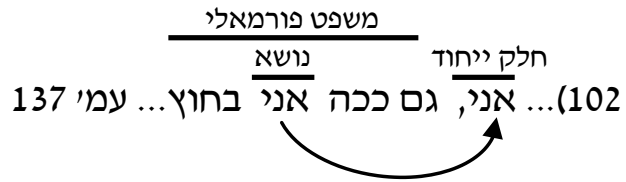

Extraposición Sujeto

102)...уyo, también así yo estoy afuera... Pág. 137 


\section{3- Koby Dadón}

Koby é o irmão mais velho. Dorme com a mãe para que seus irmãos menores, Yitzik e Dudi, não sintam a falta do pai em casa, já que ele morreu quando os dois eram muito pequenos. Koby trabalha em uma fábrica onde há uma hierarquia préestabelecida; não tem possibilidade de progredir nesta aldeia onde vive. Este personagem aparece sempre em crise emocional, chegando a explodir no final de seu monólogo.

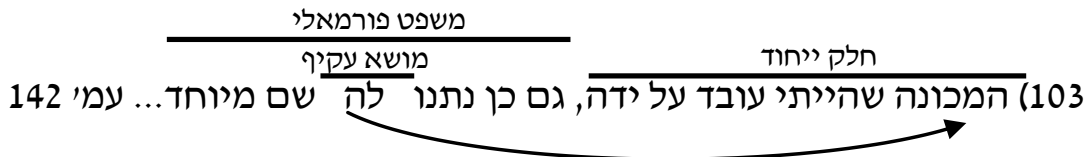

Extraposición Objeto indirecto

103) La máquina con la que trabajaba, también le dieron un nombre especial...Pág. 142

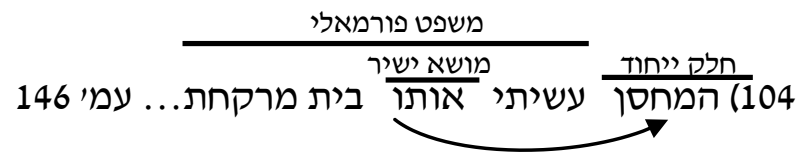

Extraposición Objeto directo

Oración formal

104) El depósito lo hice una farmacia...Pág. 146 


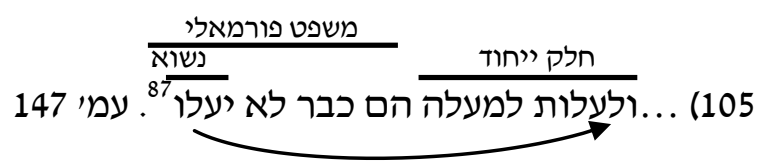

105)...y subir ellos ya no suben. Pág. 147

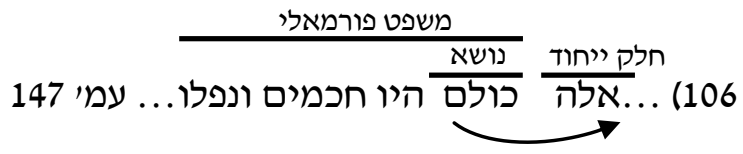

106)...estos $\frac{\text { Oración formal }}{n} \frac{\text { Sujeto }}{\text { todos }}$ fueron sabios y cayeron... Pág. 147

107) הלק ייחוד

107) Extraposición $\frac{\text { Oración formal }}{\text { El sabio - directo }}$ ojus ojos en la cabeza. Pág. 148

${ }^{87}$ Este é o único exemplo de extraposição do predicado que encontrei neste livro.

${ }^{88}$ Esta frase está originalmente no livro de Eclesiastes 2, 14. Hoje em dia passou a ser um ditado popular. 


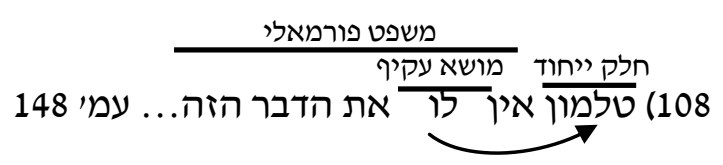

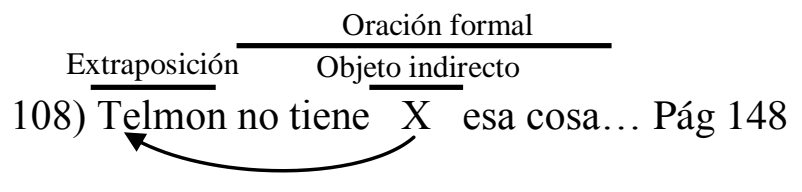

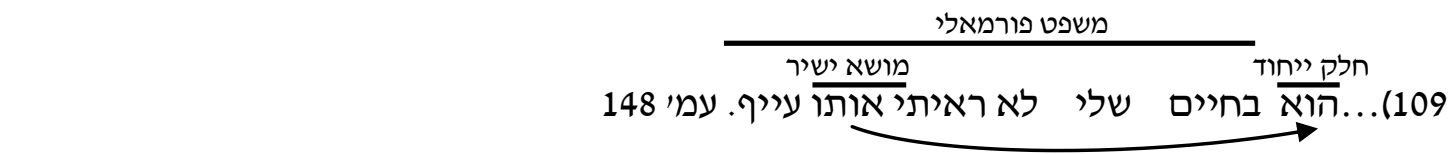

109)...él en mi vida lo vi cansado. Pág. 148

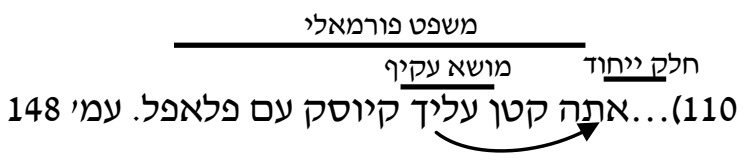

Oración formal

Extraposición Objeto indirecto

110)...tú te queda chico un kiosco de falafel. Pág. 148

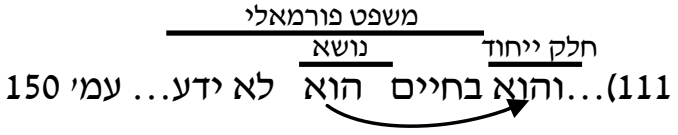




Extraposición
111)...y eración formal
en su vida $\stackrel{\text { Sujeto }}{\text { êl }}$ supo...Pág 150

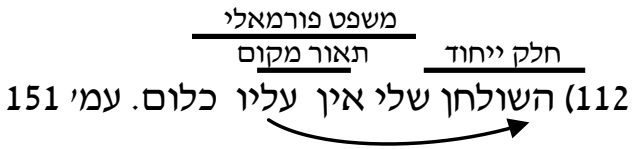

112) $\frac{\text { Extraposición }}{\text { Mi mesa no hay }} \frac{\text { Oración formal }}{\frac{\text { M. directo }}{\text { sobre ella }}}$ nada. Pág. 151

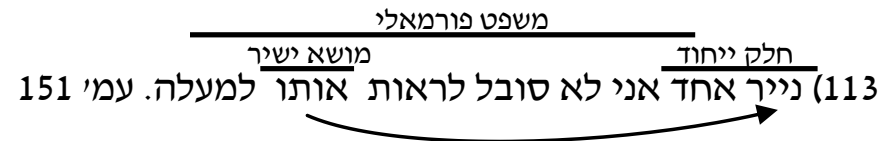

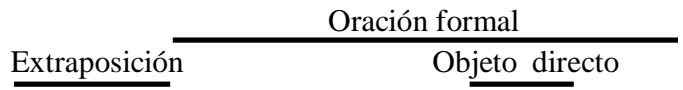

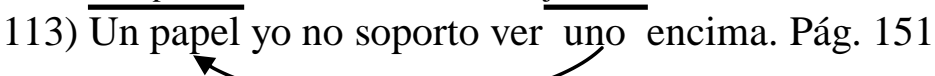

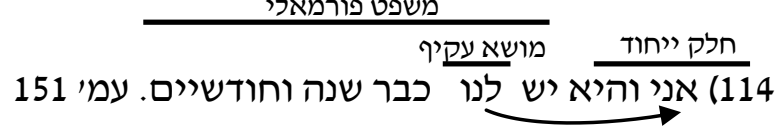


Extraposición Objeto indirecto

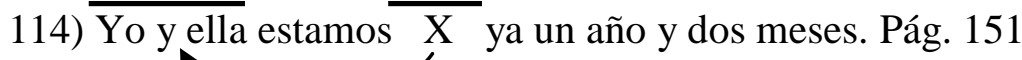

Yo ya estamos $\mathrm{X}$ yan año y dos meses. Pág. 151

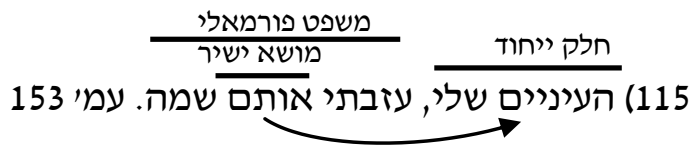

Extraposición Objeto directo

115) Mis ojos, los dejé allí. Pág. 153.

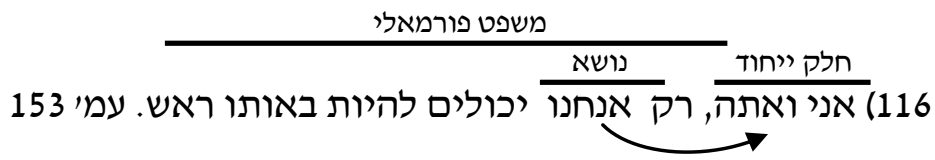

Oración formal

Extraposición Sujeto

116) Yo y tú, sólo nosotros podemos tener la misma cabeza. Pág. 153
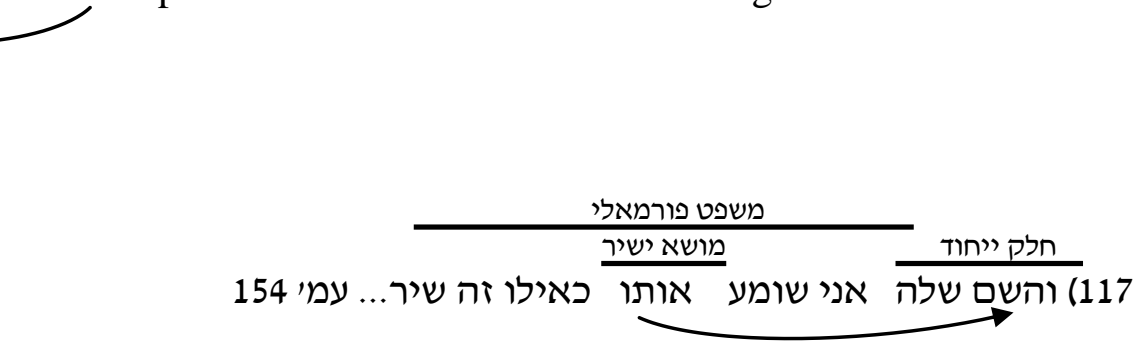
Extraposición Objeto directo

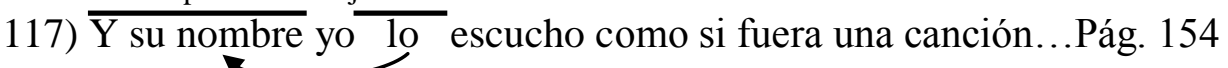

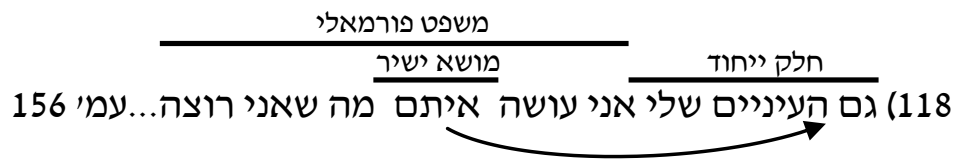

Oración formal

Extraposición Objeto directo

118) También mis ojos hago con ellos lo que yo quiero...Pág. 156
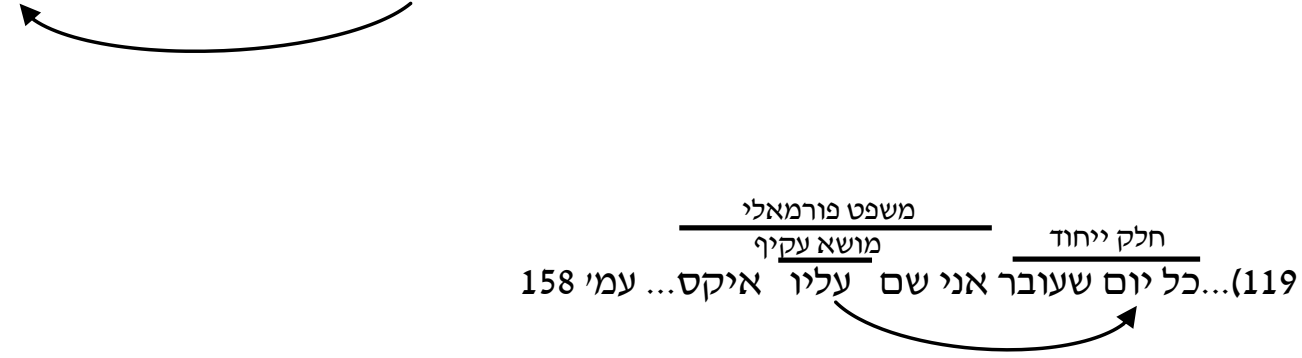

119)...Cada día que pasa pongo en él una equis... Pág. 158

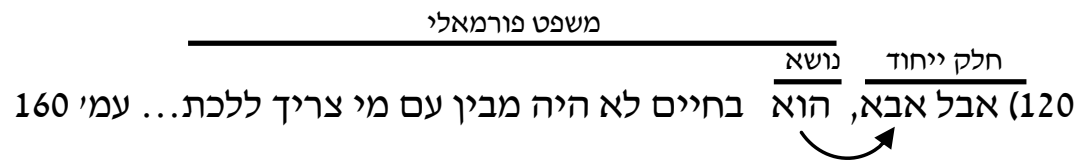




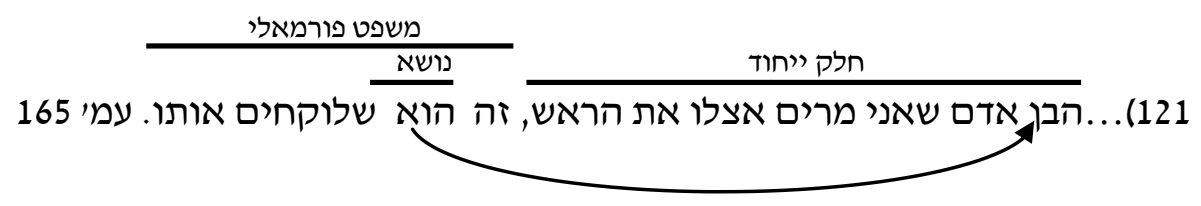

121)...el ser humano que le levanto la cabeza, es $\frac{\text { Oxación formal }}{\frac{\text { Sujeto }}{\text { él }}}$ al que toman. Pág. 165

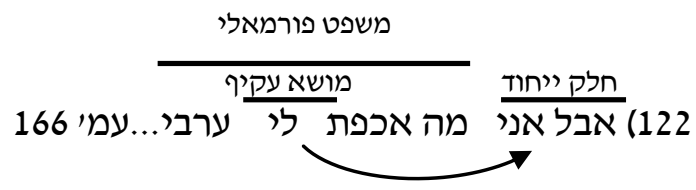

Extraposición Objeto indirecto

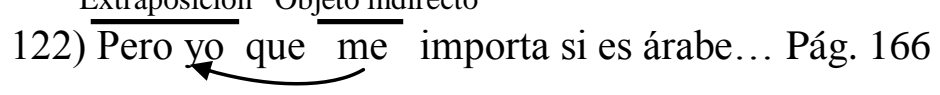

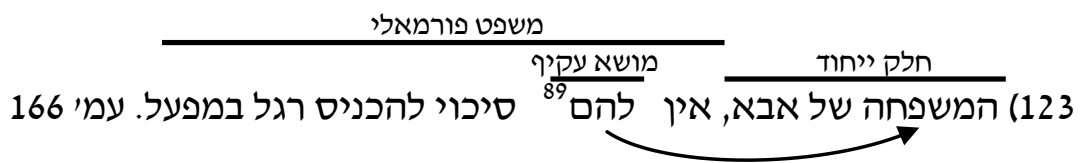

${ }^{89}$ Neste caso, a falta de concordância de gênero e número dá-se por considerar as palavras família ou gente como plural, embora a morfologia seja singular. 


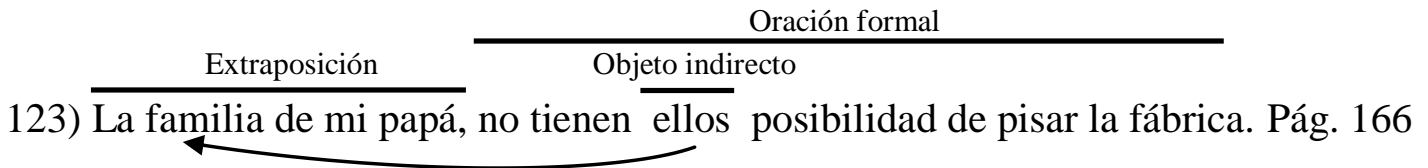

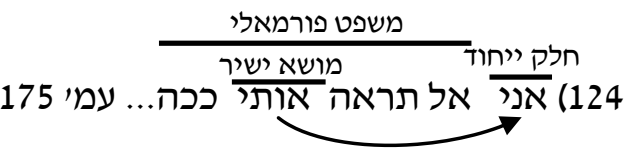

Extraposición $\frac{\text { Objeto dión formal }}{\text { 124) }}$

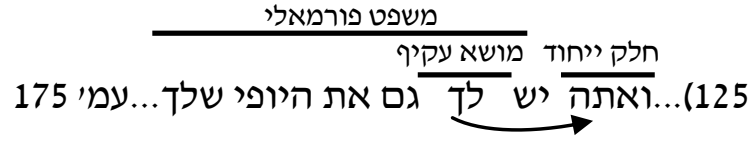

Oración formal

Extraposición Objeto indirecto

125)...y tú tienes $\mathrm{X}$ tu belleza...Pág. 175

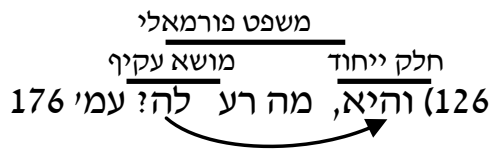




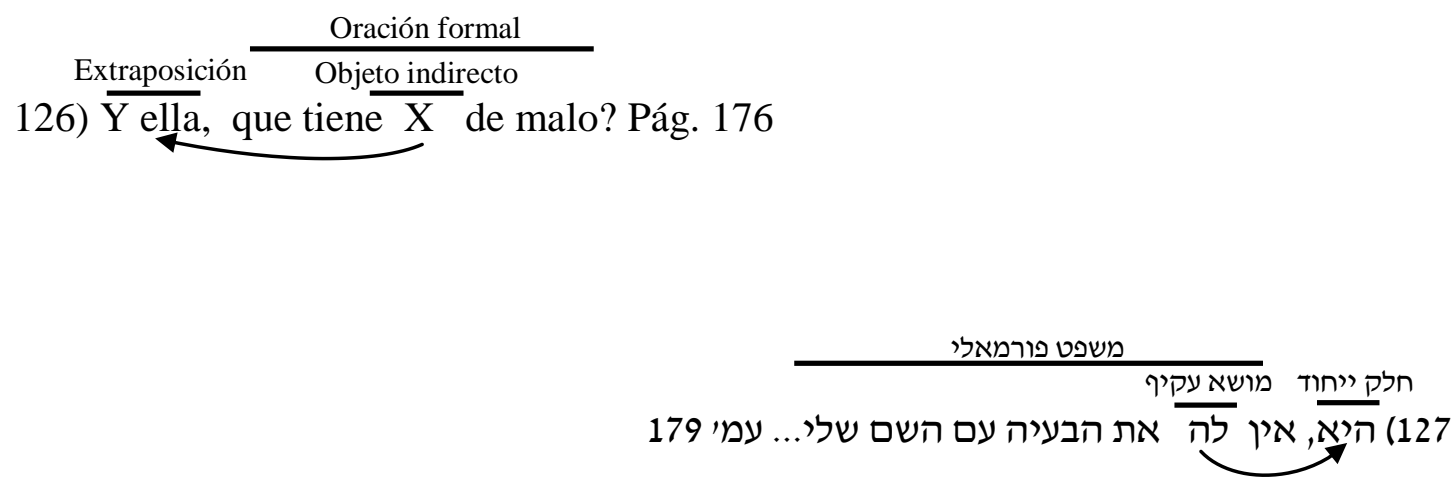

Oración formal

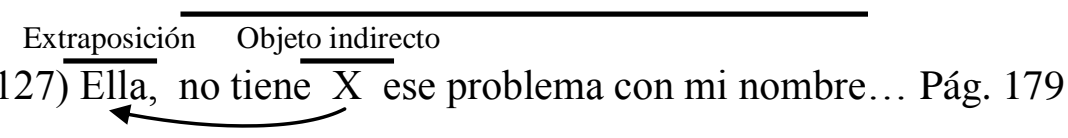

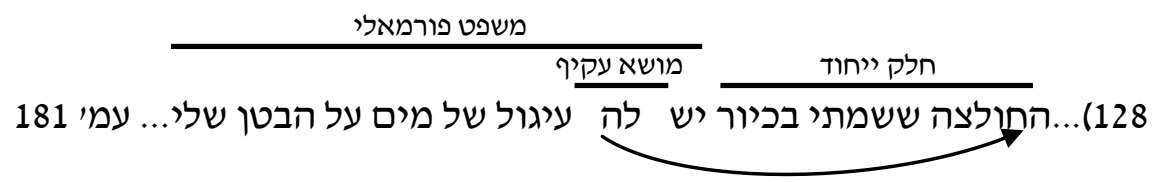

Oración formal

Extraposición

Objeto indirecto

128)...la remera que puse en la pileta tiene $\overline{\mathrm{X}}$ un redondel de agua...Pág. 181

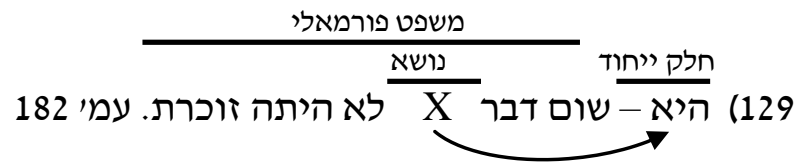


129) $\frac{\text { Oración formal }}{\frac{\text { Extraposición }}{\frac{\text { Sujeto }}{X}} \text { se acordaba. Pág. } 182}$

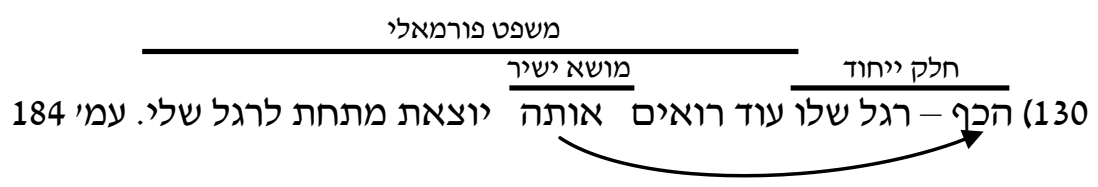

Oración formal

Extraposición Objeto directo

130) Su planta del pié todavía se la ve saliendo debajo de mi pié. Pág. 184

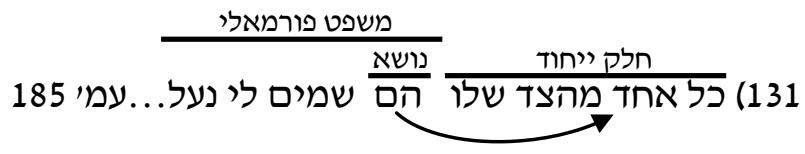

131) $\frac{\text { Extraposición }}{\text { Cada uno de su lado }} \frac{\text { Oración formal }}{\frac{\text { Sujeto }}{\text { ellos }} \text { me ponen el zapato... Pág } 185}$

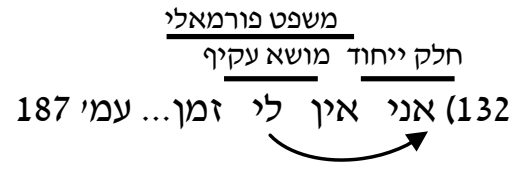

Extraposición $\quad$ Obación formal

132) $\longdiv { Y _ { 0 } }$ no tengo X tiempo... Pág. 187 


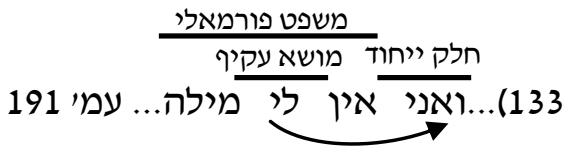

133)... Еxtraposición yo tengo $\frac{\text { Objeto indirecto }}{\mathrm{X}}$ palabra... Pág. 191

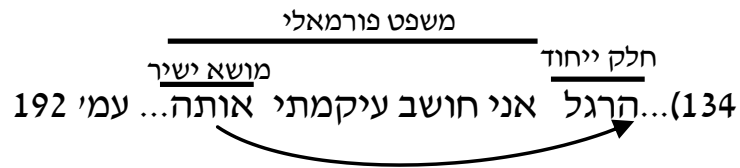

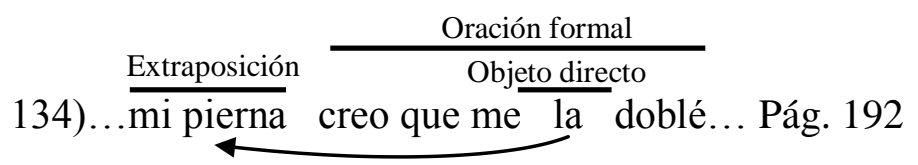

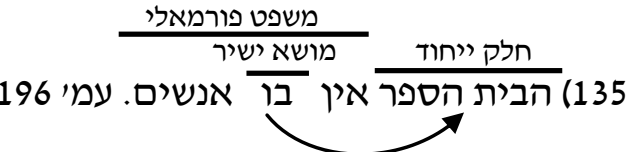

135) $\frac{\text { Extraposición }}{\text { La escuela }} \frac{\text { Oración formal }}{\text { Objeto directo }}$ 


\section{4- Ety Dadón}

O último monólogo deste romance é o de Ety Dadón, a única filha mulher. Seu idioma não é como o das demais pessoas que vivem ao seu redor. Parece que sua alma abandonou a aldeia, deixando ali somente o corpo. A obsessão por avançar na vida e melhorar o idioma a mantêm conectada ao rádio, tentando imitar os locutores. Ao longo de seu monólogo aparece uma luta interna para contar aos gêmeos, seus irmãos mais novos, a verdade sobre o pai falecido. Por outro lado, duvida em fazê-lo por não querer romper a estrutura familiar. Sua sensibilidade se expressa na maneira com que cuida dos irmãos como se fosse a mãe.

No final da história, Ety decide calar-se. Com o conto "A mulher que se transformou em polvo" (Haishá she nehefchá letamnum) conta aos irmãos a verdade sobre o pai e os mecanismos opressivos que abateram a mãe.

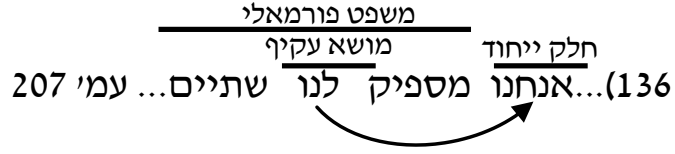

Extraposición $\quad$ Oración formal

136)... nosotros suficiente para nosotros dos... Pág. 207

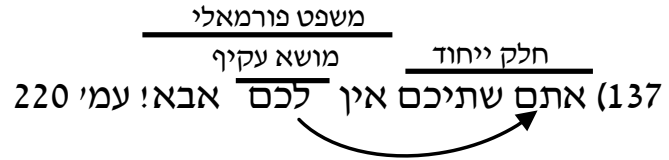


137) $\frac{\text { Extraposición }}{\text { Ustedes dos }} \begin{gathered}\text { Oración formal } \\ \text { no tieneto indirecto } X\end{gathered}$

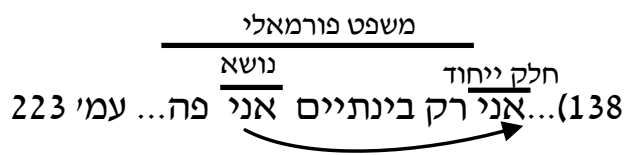

138)... Extraposición sólo por ahora $\frac{\text { Sujeto }}{\text { yo }}$ estoy acá... Pág. 223

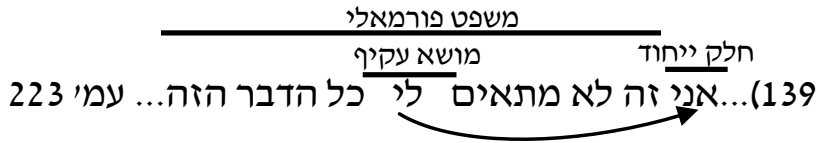

Oración formal

Extraposición Objeto indirecto

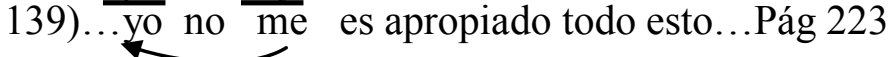

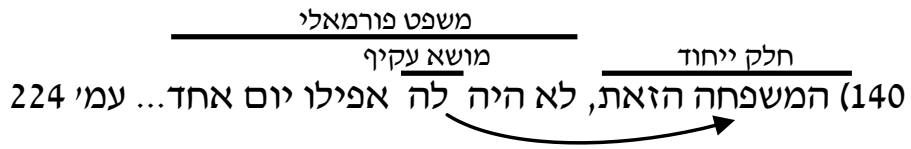




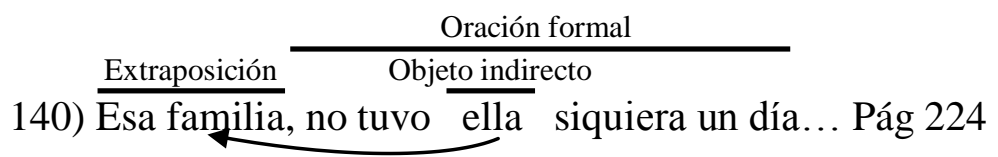

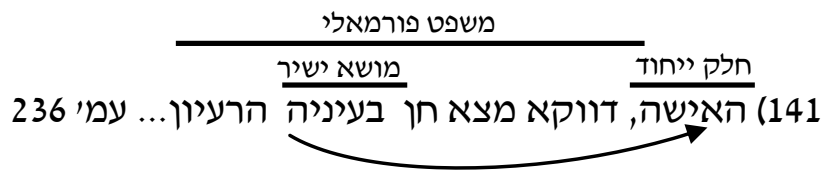

141) $\frac{\text { Extraposición }}{\text { La mujer, justamente } \frac{\text { Objeto directo }}{\text { le }} \text { pareció buena idea... Pág. } 236}$

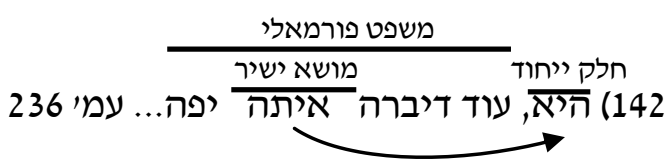

\footnotetext{
Oración formal

Extraposición Objeto directo

142) $\overline{\text { Ella, todavía le }}$ habló bien...Pág. 236
}

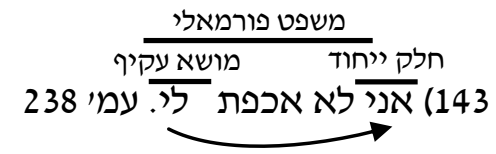


Oración formal

Extraposición Objeto indirecto

143) $\overline{\mathrm{Yo}_{\mathrm{O}}}$ a mí no me importa. Pág. 238

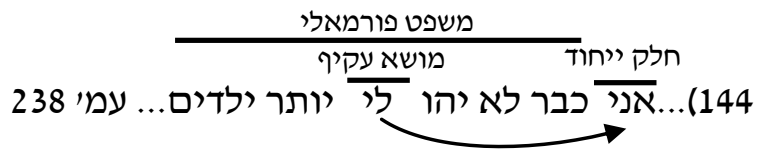

\begin{tabular}{l} 
Extraposición \\
Obación formal \\
\hline .... Yo ya no voy a tener X más hijos. Pág. 238
\end{tabular}

\section{4- Conclusão parcial e avaliacõos}

Segundo o que se observou e analisou os resultados, em termos estatísticos e sintáticos, são idênticos aos que pressupõe esta pesquisa. Das 144 extraposições, a maior quantidade corresponde ao objeto indireto (56), seguido pelo objeto direto (39). Este resultado não surpreende já que, como foi explicado no item 3.2 do capítulo "Fundamentos Teóricos", os casos mais frequentes de orações com extraposição são aquelas orações nas quais a extraposição é um substantivo e a marca da oração formal está na posição de objeto. Seguem, em quantidade, o sujeito (32) e o modificador direto (12).

Em relação ao circunstancial de lugar de que encontrei somente quatro casos, não surpreende que haja tão poucos, já que é difícil extrapor um circunstancial por sua essência de predicado. Como a oração extraposta enfatiza a função do sujeito, 
cuja posição é substantiva, é factível que um componente, que é de natureza predicativa, não apareça em geral nesta posição ${ }^{90}$. (Ver item 3.1)

Em último lugar encontram-se as orações onde se extrapôs o predicado (1), o que é lógico por seu valor predicativo absoluto.

Retomando os resultados em termos de orações extrapostas por capítulo, é muito interessante descobrir que o nível intelectual dos personagens é inversamente proporcional à quantidade de extraposições em seu monólogo. Com isto quero dizer que, quanto mais escolaridade tenha, menos extraposições usará em seu relato. No capítulo onde há mais extraposições (45\%) é no de Yitzik e Dudi e não me surpreende já que, além de ser um dos capítulos mais longos, estamos falando de dois garotos pequenos que interromperam seus estudos no primário e sua educação principal provém da rua.

O segundo capítulo com mais extraposições (25\%) é o de Simona Dadón. Ela veio do Marrocos muito jovem e o ambiente onde cresceu, entre falantes do árabe e francês e com poucos recursos, fez com que sua linguagem fosse de registro baixo.

O terceiro capítulo com mais extraposições $(23,5 \%)$ é o de Kobi Dadón, o irmão mais velho, que pôde estudar em uma escola até a morte do pai, isto é, até os 13 anos. O capítulo com menos extraposições $(6,5 \%)$ é o de Ety Dadón e é claro que isto se deve a sua necessidade e incentivo de aprender imitando a locutora de rádio Rehuma Eldar. Creio haver deixado claro, depois desta busca e análise exaustiva do livro, que o uso de orações extrapostas intensifica a sensação de estar na presença de um hebraico de registro baixo.

\footnotetext{
${ }^{90}$ Sobre este assunto escreve Ora Schwartzwald; ela cita que: "nos complementos do verbo sobressaem os seguintes fenômenos: com algumas preposições como 'be'(ב) , 'al'(על) , 'lifnei'(לפנ) , 'acharei' (אחרי), utilizadas como circunstanciais de lugar em orações extrapostas. A marca será a ênclise que lhes é inerente, ou seja que a extraposição possua um componente [+ vivo] que não o tenha; em outras preposições como 'el'(אל) , 'min' (מן), utilizadas como circunstancial de lugar. A marca será 'aí' (sham שם quando a extraposição carece de componente [+ vivo]. De qualquer forma, raramente se encontra uma extraposição de circunstancial que não seja locativo e que não tenha o componente [+ vivo]." (Schwartzwald, Pág. 335). Entre os exemplos que apresenta:

- A gaveta, Dan a colocou sobre as prateleiras- המגירה, דן שם בה את המדפים

- Jerusalém, ele viajou até lá- ירושלים, הוא נסע לשם

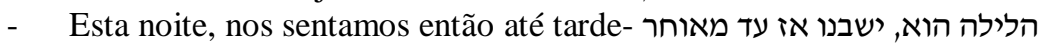

Mais exemplos podem ser encontrados IBIDEM. A fonte destas orações não foi citada e em todas as orações expostas, a extraposição é um substantivo e a preposição que indica a adverbialidade foi anulada.
} 


\section{Capitulo 4- Sintaxe Bíblica}

\section{A extraposição nas fontes judaicas}

A ampla gramática da língua hebraica está baseada nas estruturas que aparecem nas fontes judaicas (Bíblia e Talmud), quer dizer que a Bíblia e o Talmud são os livros de consulta, por excelência, da gramática hebraica. Todo fenômeno que aparece nestas fontes deve ser considerado como parte da gramática hebraica. Isto se deve a que durante a época bíblica e talmúdica o hebraico era uma língua viva, em que se produziam mudanças linguísticas de maneira natural. Isto se pode ver nas mudanças morfológicas entre estas duas épocas, segundo a literatura bíblica e talmúdica. Uma língua viva é uma língua que se modifica. Quando se observam as mudanças na morfologia, fonética e sintaxe do hebraico, comparando estas duas etapas, não cabe dúvida de que estamos falando de uma língua viva.

Considerando isto, é importante revisar a extraposição nas fontes, começando pela Bíblia, e desta maneira determinar se este fenômeno é parte do hebraico ou é exclusivo de algum registro do idioma.

É necessário descrever o contexto, as teorias e práticas que se manejavam para interpretar a extraposição na Bíblia.

\subsection{Propostas para a compreensão da extraposição bíblica}

Existem diversas propostas fortes para a compreensão deste fenômeno na Bíblia. Por um lado os Massoretas ${ }^{91}$ viam este tipo de estruturas como orações compostas. A primeira parte seria o sujeito e a segunda parte o predicado. O sujeito se antepõe na oração, com o fim de enfatizá-la, e logo aparece a nova informação (função dada ao predicado) que modifica o sujeito. É no predicado que se encontra o rastro do membro extraposto.

\footnotetext{
${ }^{91}$ Grupo de sábios que trabalharam durante centenas de anos, cujo objetivo era interpretar a Bíblia de acordo com o que foi transmitido por gerações, contando palavras, frases ou diferentes fenômenos. $\mathrm{O}$ objetivo principal era criar um estilo uniforme que fosse aceitável para todas as comunidades judaicas. Os Massoretas inventaram os signos vocálicos usados para descrever a maneira exata de ler a Bíblia, adicionaram comentários e anotações que ajudam a manter a exatidão do texto entregue. Seu trabalho começou na época de Esdras e Nehemias (450 A.C) e se prolongou até o século 10 da era comum.
} 
Quero esclarecer que na tradução da Bíblia nem sempre se poderá ver o fenômeno de maneira precisa, por isso tratarei de explicar as diferenças entre idiomas no caso de ser necessário.

- הujeto

A tradução desta frase na Bíblia é: “Él (Dios) es la Roca, cuya obra es perfecta”. É evidente que, para entender este tipo de oração, é necessário fazer a uma análise do contexto, para inferir o porquê da extraposição.

Ornán $^{92}$ prefere analisar a extraposição como uma oração simples com uma transformação em sua estrutura profunda ${ }^{93}$.

De acordo com esta teoria, a oração em sua estrutura profunda é:

- La obra de la roca es perfecta

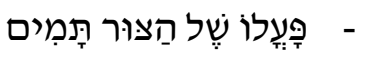

A esta estrutura se aplicam transformações: retira-se o componente "La roca" e o extrapomos ao começo da oração, deixando como rastro o adjetivo possessivo "Su" no lugar que é abandonado.

- La roca - perfecta es su obra.

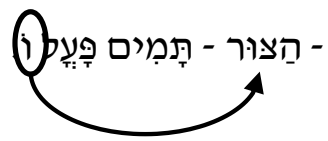

A oração resultante é também uma oração complexa mas não composta, em termos sintáticos.

Então, segundo Ornán, a análise sintática desta oração seria a seguinte:

${ }^{92}$ Ver Ornán, 1989, Pág. 104.

${ }^{93}$ A gramática generativo-transformacional de Chomsky mostra que quando analisamos várias orações aparentemente distintas, podemos perceber que estas possuem a mesma estrutura, ou que orações aparentemente iguais têm estruturas distintas. Ele sugere que, na linguagem, cabe distinguir dois níveis: o nível da estrutura profunda ou de base que só se vê através da análise linguística, e que é a estrutura que está na mente, sobre a qual se executam transformações linguísticas aparecendo a oração que se enuncia, e estrutura superficial que é o enunciado tal e como o dizemos. 
Em sua estrutura profunda,

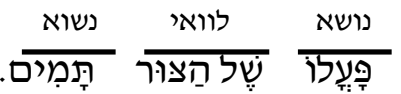

Em sua estrutura superficial,

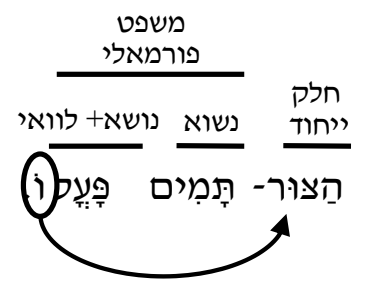

Sua tradução seria,

$$
\frac{\text { Sujeto }}{\text { La obra }} \frac{\text { Modificador directo }}{\text { de la roca }} \frac{\text { Predicado }}{\text { es perfecta }}
$$

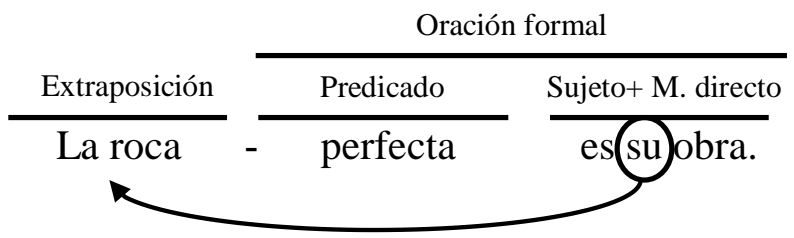

Vou continuar dando alguns exemplos da Bíblia, para que este fenômeno fique claro. Por meio destes exemplos podemos ver que, também nas fontes, qualquer posição sintática pode ser extraposta.

\subsection{Exemplos de extraposição segundo a categoria sintática}

\subsubsection{Extraposição de um objeto direto.}

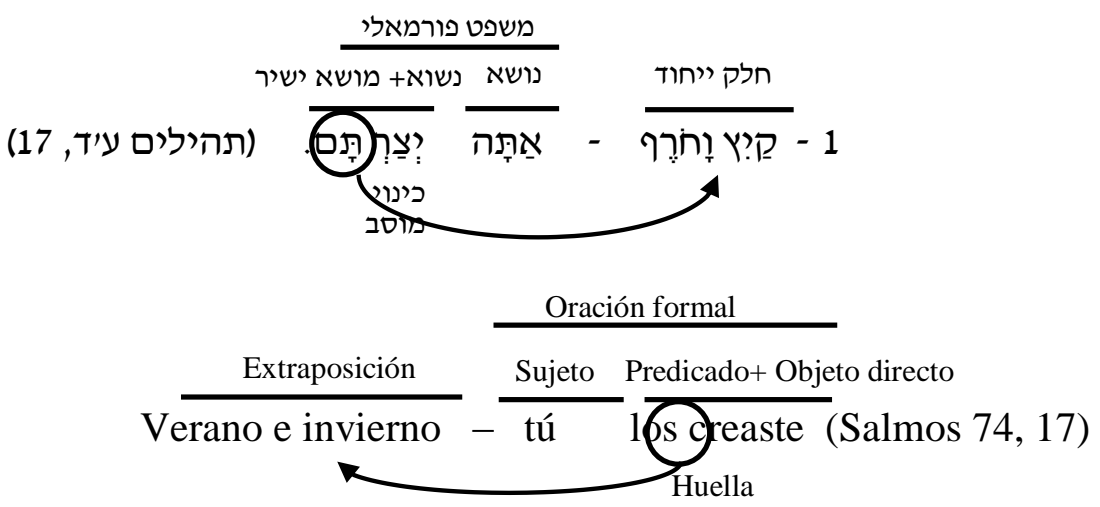


A estrutura profunda seria:

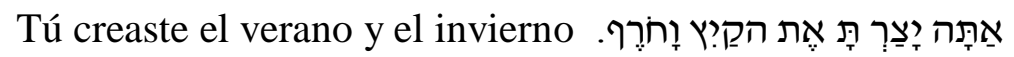
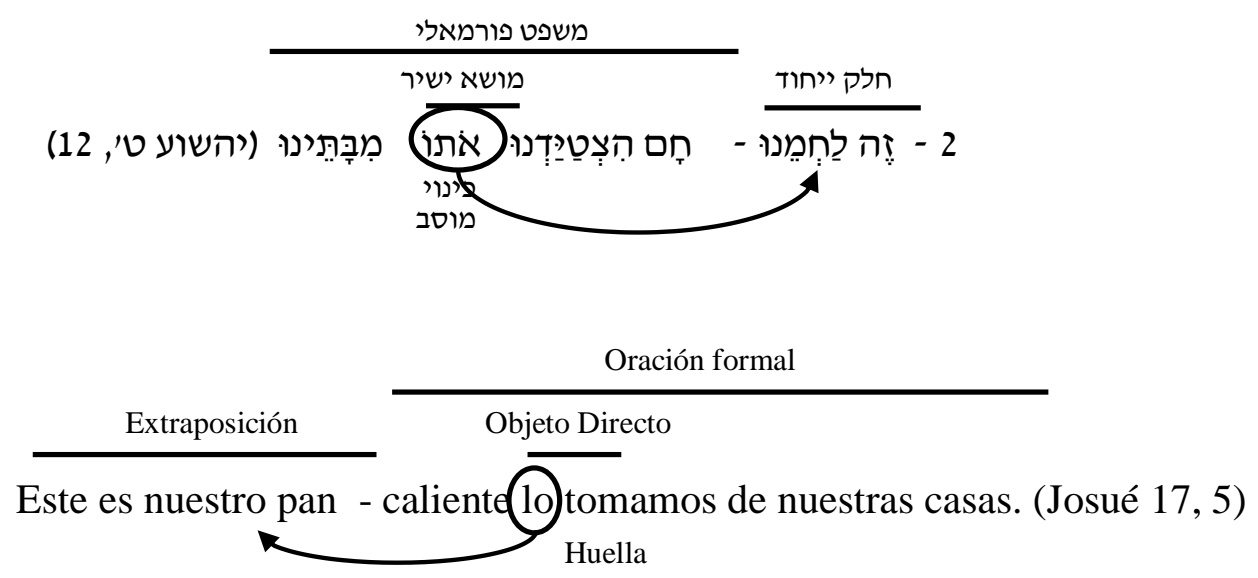

A estrutura profunda seria:

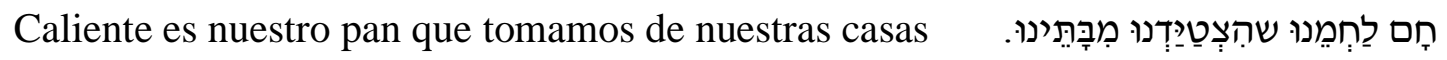

Este próximo exemplo mostra a extraposição do sujeito.

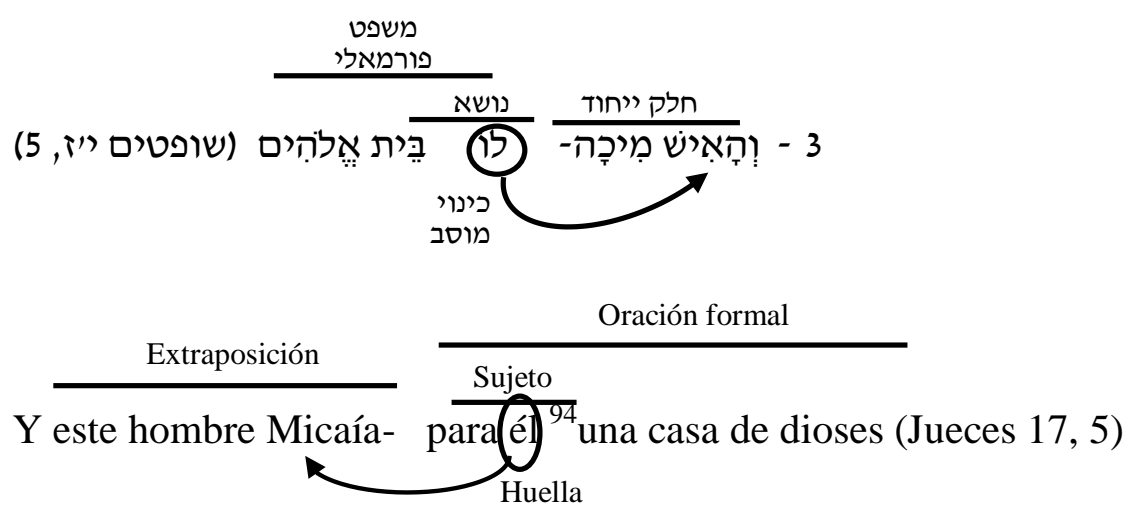

A estrutura profunda seria:

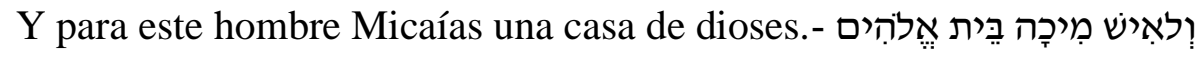

\footnotetext{
${ }^{94}$ Esta é uma estrutura difícil de explicar pela carência do verbo em hebraico e a falta de contexto.
} 


\subsubsection{Extraposição do objeto indireto}
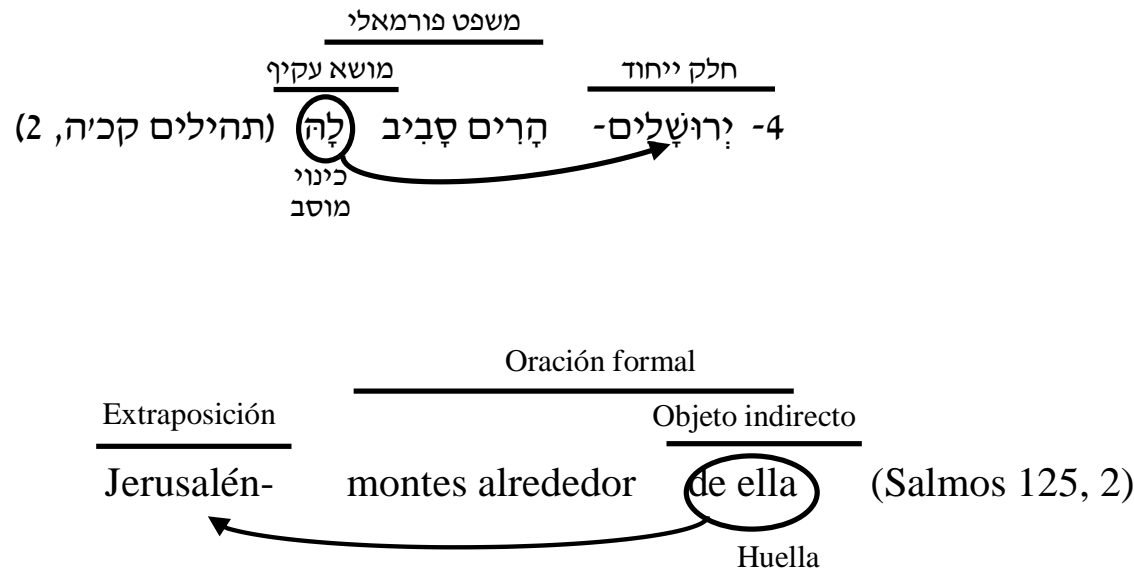

A estrutura profunda seria:

Montes alrededor de Jerusalén. הרים סביב לירושלים

Nesta oração, o contexto desempenha um papel muito importante para a extraposição, já que o que se tenta fazer é gerar um paralelismo entre Jerusalén e Dios. Isto só se poderá observar se lermos a segunda parte do versículo:

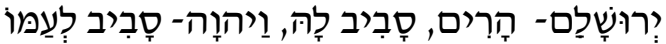

Jerusalén- montes alrededor de ella, Dios- está alrededor de su pueblo

Se não se produzisse a extraposição, este paralelismo sintático e semântico não existiria. 


\subsubsection{Extraposição do circunstancial de lugar}

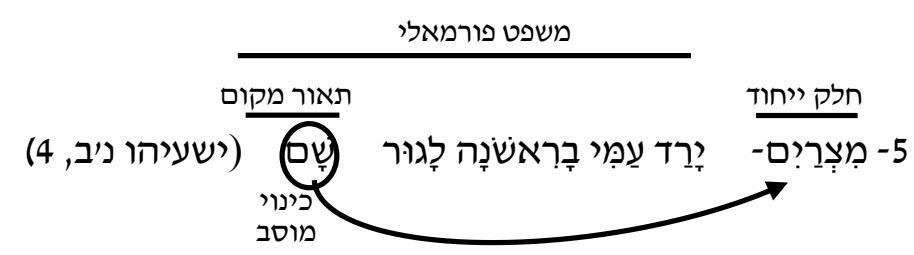

Oración formal

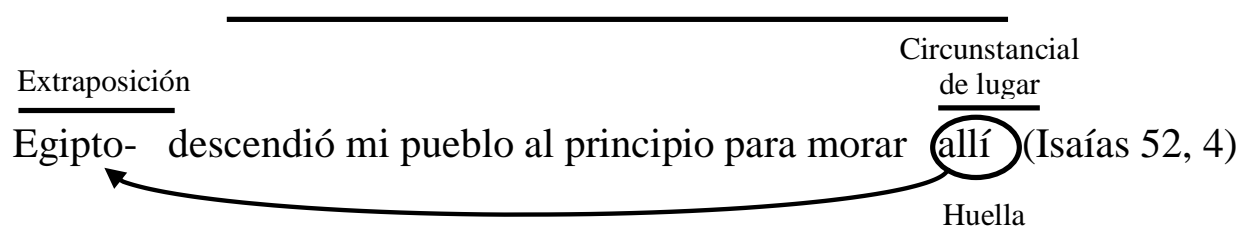

A estrutura profunda seria:

ירד עמי בראשונה לגור שם . Descendió mi pueblo para morar en Egipto.

\subsubsection{Extraposição do predicado}

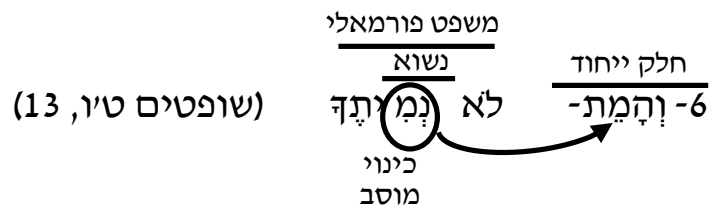

Neste caso, o que se extrapola é a raiz verbal e não a declinação nominal.

Hoje em dia, este tipo de oração em hebraico se diria da seguinte forma:

\section{להמית- לא נמית אותך.}

É muito comum ver este tipo de estrutura em hebraico antigo. Semanticamente há uma ênfase do elemento reiterado, isto é, uma estrutura que gera um superlativo.

Por isso encontramos formas como "O cântico dos cânticos", entendendo que é o maior dos cânticos já visto. 


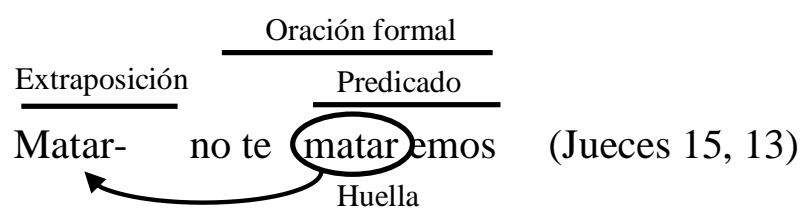

A estrutura profunda seria:

לא נמיתך . No te mataremos

\subsubsection{Extraposição do complemento locativo ${ }^{95}$.}
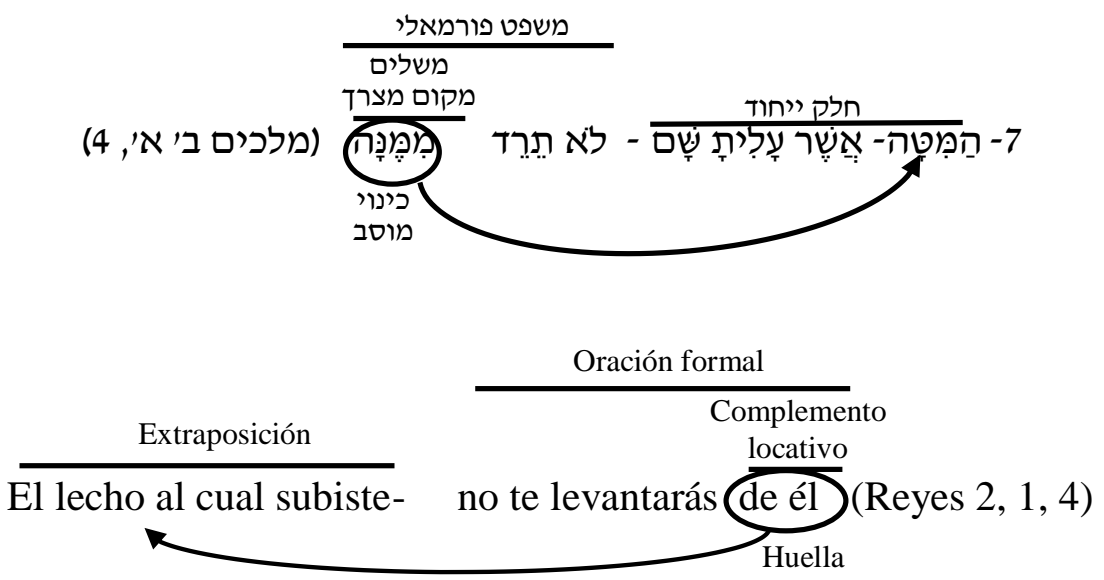

De acordo com o que se observa, concluo que, neste caso, a extraposição se produz por uma questão de estilo, já que na estrutura profunda não se poderia apreciar a contraposição entre os verbos "subir" e "bajar". Desta maneira gera-se certa tensão, já que o leitor fica á espera do que se passará no leito ao qual subiu o protagonista. $\mathrm{Na}$ forma profunda, a resposta está revelada desde o começo.

A estrutura profunda seria:

\footnotetext{
${ }^{95}$ Ver Honrubia 1988, Pág. 150. Honrubia explica que há verbos chamados locativos que exigem um complemento locativo. Este complemento é parte da estrutura verbal e o verbo não pode atuar sem este complemento.
} 
אo te levantarás del lecho al cual subiste. לא תרד מהמיטה אשר עלית שם

\subsubsection{Extraposição do modificador direto}
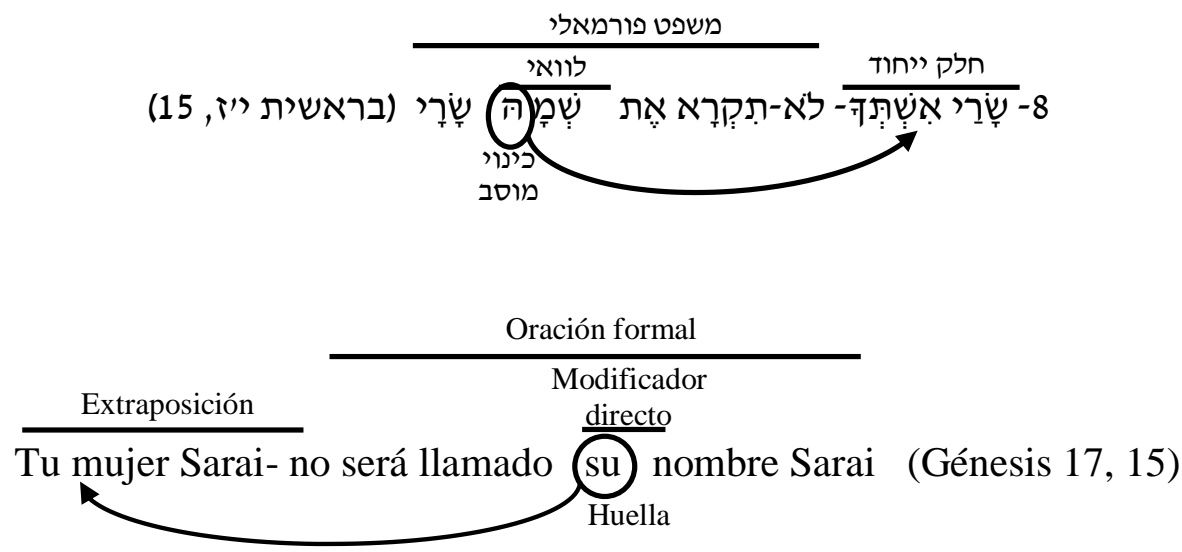

Neste caso, extrapõe-se "Tu mujer Sarai", já que é um momento muito importante da história relatada, e é necessário enfatizar o tema que será tratado.

A estrutura profunda seria:

לא תיקרא את שם שרי אשתך שרי No será llamado el nombre de Sarai tu mujer Sarai

\section{3- Extraposicão de sujeito ou predicado na Bíblia}

Quando analisamos orações do tipo substantivas, caso muito comum em hebraico pela falta de verbos de ligação, existem duas análises possíveis. Neste tipo de oração, onde apareceria um verbo de ligação como predicado em idiomas em que este existe, em hebraico aparece o pronome pessoal concordando com o sujeito.

Um exemplo para esclarecer este fenômeno.

Ha yeladim hem ${ }^{96}$ gdolim- Los niños son grandes- הילדים הם גדולים

\footnotetext{
${ }^{96}$ Neste caso, o pronome pessoal "hem" (terceira pessoa do plural, masculino) ocupa o lugar do verbo "ser" na oração paralela em espanhol. Como expliquei anteriormente, este pronome concorda em género e número com o sujeito, neste caso "Yeladim", isto é "niños".
} 
Primeira análise:

$\frac{\text { נשואים }}{\text { הילדים }} \frac{\text { נשואים }}{\text { Modificador }}$
$\frac{\text { Sujeto }}{\text { Los ninos }} \frac{\text { Predicado }}{\text { Son }} \frac{\text { directo }}{\text { grandes }}$

Segunda análise:

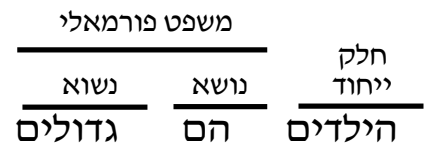

$$
\begin{aligned}
& \frac{\text { Extraposición }}{\text { Los niños }} \frac{\text { Oración formal }}{\text { Soneto }^{97}} \quad \frac{\text { Predicado }}{\text { grandes }}
\end{aligned}
$$

Vou trazer exemplos deste tipo de orações na Bíblia e tentarei explicar o porquê de sua estrutura. Focalizarei no segundo tipo de análise, já que o que proponho é revisar a extraposição.

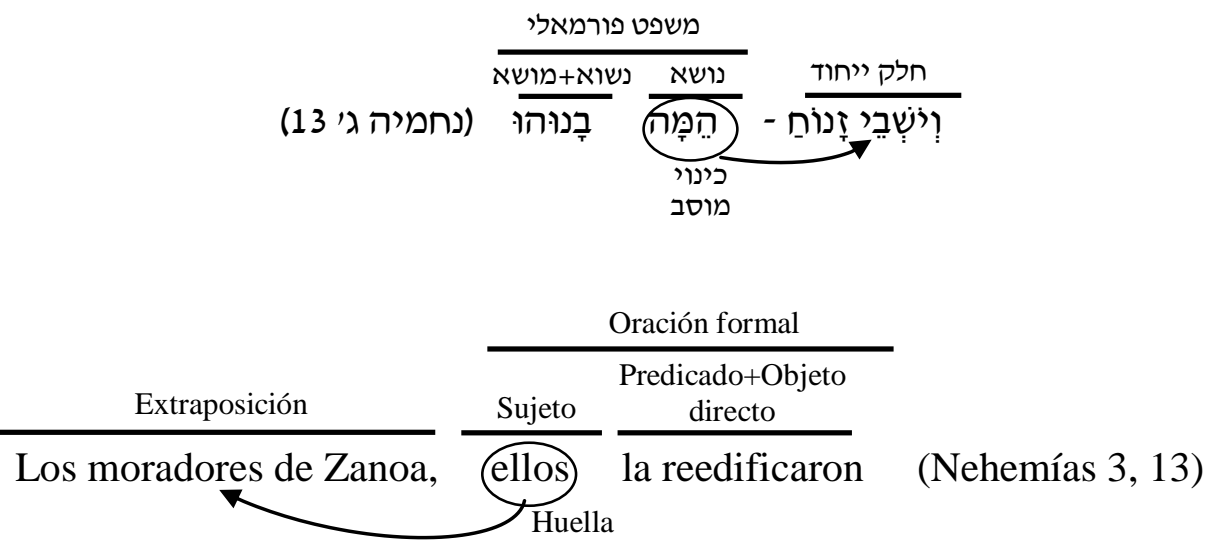

A estrutura profunda seria:

המה בנוהו -Ellos la reedificaron

${ }^{97}$ Quero voltar a esclarecer que, ainda que esta esteja não seria a análise em espanhol, o que fiz foi traduzir literalmente as orações assim como as categorias sintáticas. 


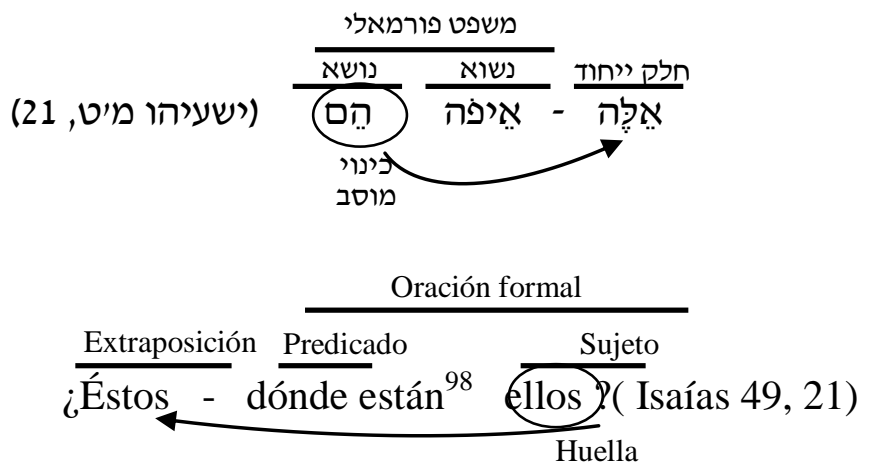

A estrutura profunda seria:

¿Ellos dónde están?- איפה אלה

A partir de agora, continuarei analisando só o que for relevante ao fenômeno em questão.
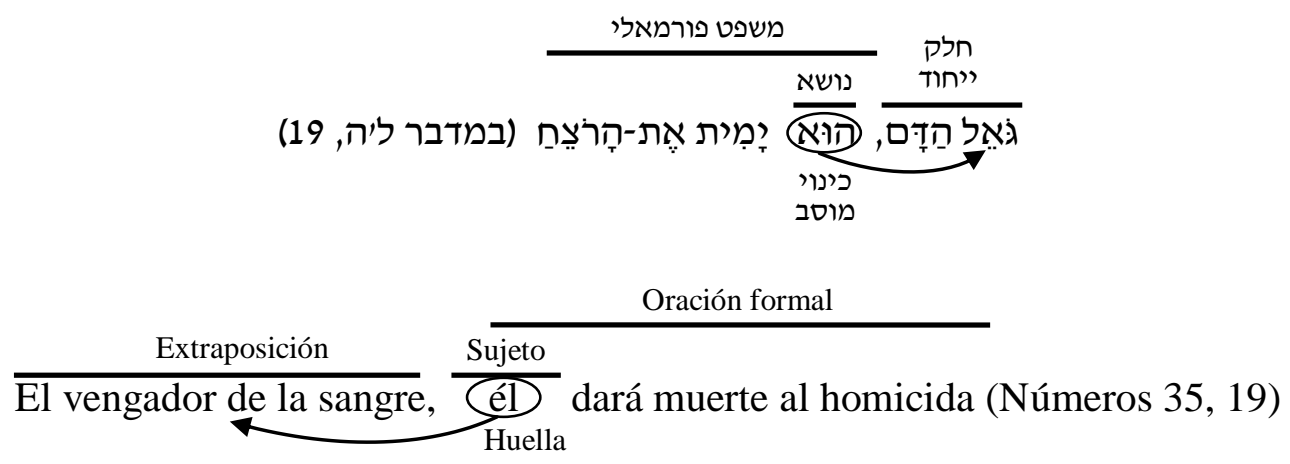

A estrutura profunda seria:

Él dará muerte al homicida- הוא ימית את הרוצח

Nesta oração, foi necessário enfatizar o pronome, já que, segundo o contexto, era importante esclarecer que ele (o vingador do sangue), e nenhum outro, seria o assassino do homicida.

\footnotetext{
${ }^{98}$ É importante explicar que o verbo "estaban" não é considerado como predicado, já que em hebraico este não existe e, portanto, não tem presença fonética. Tive que agregá-lo em seu paralelo em espanhol, já que de, outra forma, a oração seria ininteligível.
} 


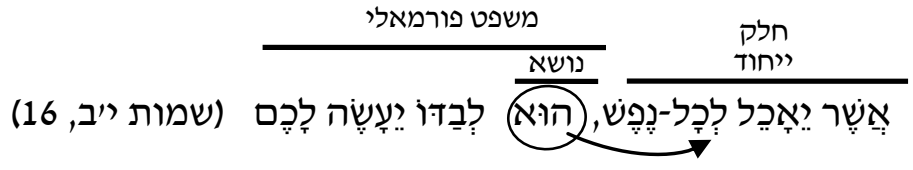

$\frac{\text { Extraposición }}{\text { El que les dé de comer, }} \frac{\text { Sujeto }}{\text { éd solo les prepararán formal la comida. (Éxodo 12, 16) }}$

A estrutura profunda seria:

Eוl solo les preparará la comida- הוא לבדו יעשה לכם

\section{4- Classificação da extraposição "sujeito"}

Esta estrutura, em que a extraposição é sujeito, costuma ser muito difícil de analisar, especialmente quando o sujeito e o predicado da oração são da mesma categoria gramatical, sendo muito complicado estabelecer a função sintática de cada um.

No caso do hebraico, esta confusão se pode observar principalmente nas orações onde o predicado não é verbal. Quando há uma oração em que seus dois únicos componentes pertencem à mesma categoria gramatical, há novas ferramentas por conhecer, para realizar uma análise com éxito.

Para conhecer estas ferramentas, é importante notar como se coloca um artigo definido antes de um substantivo. Em hebraico, uma palavra recebe o artigo, prefixando a letra "hei” (ה) antes do substantivo.

Yeled (ילד) menino- Hayeled (הילד) o menino.

Ishá (אישה) mulher- Haishá (האישה) a mulher.

No caso haver ter duas palavras formando uma oração, aquela com artigo será o sujeito. 
הילד תלמיד -El niño (es) estudiante

Neste caso, o sujeito será a primeira palavra, já que está com artigo.

\subsubsection{O emprego formal do artigo}

A morfologia hebraica pode-nos indicar a presença de um artigo sem que este esteja presente foneticamente. Por exemplo, em hebraico existe uma forma de anexar um substantivo a um pronome possessivo. Esta forma conhecida como כינוי קניין (Kinui Kinyan) sempre conta com o artigo, ainda que o artigo não possa ser visto. Este fenômeno é conhecido como "emprego formal do artigo".

$$
\text { סָפְרִ = הספר שלי (sifrí = Ha sefer shelí) }
$$

Quer dizer que, nesta forma, em que o pronome possessivo e o substantivo formam uma só palavra, o artigo será empregado por definição e será sujeito neste tipo de oração.

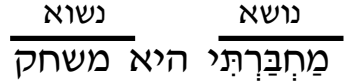

$$
\begin{aligned}
& \frac{\text { Sujeto }}{\text { Mi cuaderno es un juguete }} \stackrel{\text { Predicado }}{99}
\end{aligned}
$$

O emprego formal do artigo pode vir nas seguintes estruturas: Nomes próprios, pronomes pessoais, adjetivos demonstrativos e em construções possessivas (Smichut(סמיכות).

$$
\begin{aligned}
& \frac{\text { Sujeto }}{\text { Daniel es }} \\
& \frac{\text { Sujeto }}{\text { Él es }} \\
& \frac{\text { Sujeto }}{\text { Esta es una casa- }}
\end{aligned}
$$

\footnotetext{
${ }^{99}$ Neste caso, em hebraico observa-se que "mi cuaderno" é uma só palavra, e em "juguete" não foi empregado um artigo definido.
} 
No nome próprio "Daniel”, no pronome pessoal "Él” e no pronome demonstrativo "Esta" foi empregado formalmente o artigo; então, estas palavras serão os sujeitos de cada uma dessas orações hebraicas.

\subsubsection{Os dois componentes da oração articulados}

O conflito sintático começa quando os dois componentes da oração estão com artigo. A única maneira de estabelecer qual será o sujeito é considerar o contexto como parte da análise. Diante deste caso, é necessário recorrer à pragmática.

Como já mencionei nos fundamentos teóricos ${ }^{100}$, nestes casos há que falar dos conceitos de "Theme" (Tema) e "Rheme" (Rema). A Escola de Praga ${ }^{101}$ usou estes termos pela primeira vez. Desde a Escola de Praga a oração é considerada como uma reação do falante ante a realidade. Neste princípio baseia-se a ideia da perspectiva de análise funcional da linguagem. Os conceitos tema e rema dependem das considerações do falante sobre o discurso e da maneira pela qual este mesmo falante dispõe seu discurso. Qualquer tipo de reação diante da realidade linguística supõe para os praguenses uma tomada de postura em relação àquilo que o falante está dizendo. E, em virtude deste fator, é possível estabelecer na oração duas partes diferenciadas (e por sua vez relacionadas) pela trama do próprio discurso e pela implicação do falante no mesmo. Fala-se, pois, de uma oração composta de um tema e um rema.

Em palavras simples o tema é o que se dá por conhecido e o rema é a informação nova. Para alguns autores, o tema será a primeira peça de informação que forma o enunciado e o rema será o restante deste.

Segundo Tzdaka ${ }^{102}$, sendo o hebraico um idioma sem verbos de ligação, nas orações onde os componentes têm a mesma posição sintática, é necessário recorrer aos conceitos de Tema e Rema, ao que ele chamou "Natún" (נתון) (informação dada) e “Chidush” (חידוש) (informação nova).

\footnotetext{
${ }^{100}$ Ver rodapé 15 da página 7 do capítulo Fundamentos Teóricos.

${ }^{101}$ A escola de Praga era composta de um número de pesquisadores, que se debruçaram muito sobre o aspecto sóciocomunicativo da linguagem. Seu trabalho se desenvolveu durante a década que precedeu a Segunda Guerra Mundial.

${ }^{102}$ Ver Tzedaka 1980. Pág. 73.
} 
Os termos dado e novo marcam a relação do enunciado com o contexto, enquanto os termos tema y rema se referem ao plano informativo ou distribuição da informação. Uma conversa tem sentido graças à vontade do emissor e do receptor de desenvolvêla. Nela se troca uma série de enunciados nos quais se faz referência aos conhecimentos comuns ou compartilhados pelo emissor e pelo receptor. O falante comunica algo, geralmente novo para o interlocutor, a propósito de algo ou alguém conhecido (dado) por ambos porque se havia evocado anteriormente no transcurso dessa mesma conversa ou porque forma parte de sua enciclopédia. O intercâmbio supõe, portanto, um enriquecimento de conhecimentos:

$\frac{\text { María }}{\text { Dado }} \quad \frac{\text { ha estado aquí hoy }}{\text { Nuevo }}$

Com este enunciado o falante comunica que uma pessoa conhecida por ele e por seu interlocutor ou interlocutores, María, realizou uma ação da qual, seguramente, não tinham conhecimento.

No seguinte exemplo qualquer um dos componentes pode ser sujeito.

$$
\frac{\text { Sujeto }}{\text { Ellos son mis alumnos - נושא }}
$$

Neste caso, o que está enfatizado é o pronome, isto é "ellos" (que estou apontando ou o interlocutor já conhece) são meus alunos. "Mis alumnos" é a nova informação que quero dar e, por isso será, nesta análise, o predicado.

$$
\text { Ellos son mis alumnos - נשוא }
$$

Aqui, o que se está enfatizando é que as pessoas presentes (que estou apontando ou o interlocutor já conhece) são "mis alumnos", isto é, a nova informação se refere a que de todos os presentes, eles, são os meus alunos. 


\title{
1.5- Os três modelos de análise de Driver
}

Para analisar este tipo de estrutura na Bíblia, Driver ${ }^{103}$ classifica estas orações em três modelos:

\subsection{1- Modelo 1}

\author{
A-é $B=$

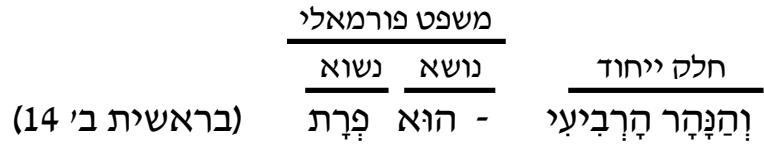

$\frac{\text { Extraposición }}{\text { Y el cuarto río }} \frac{\text { Oración formal }}{\text { Sujeto }} \frac{\text { Predicado }}{\text { es (él) }}$ el Eufrates (Génesis 2, 14)

De acordo com o contexto deste versículo do Gênesis, a ênfase está no pronome "él". Segundo a pragmática, a nova informação que se dá será o predicado, e o que já é conhecido pelo interlocutor será o sujeito da oração. Sem duvida, a novidade aqui é a apresentação do Eufrates para o leitor.

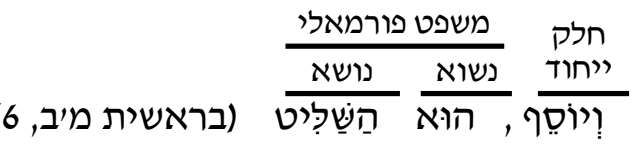

$\frac{\text { Extraposición }}{\text { Y José }} \frac{\text { Oración formal }}{\text { esedicado } \frac{\text { Sujeto }}{\text { el }} \text { señor de la tierra (Génesis 42, 6) }}$

${ }^{103}$ Ver Driver Pág. 268. 
De acordo com o contexto, em Canaã, havia fome, e vão ao Egito para pedir ao grande senhor da terra que lhes dê comida. Então nos informam que, nada mais nem nada menos, "José" o conhecido de todos os irmãos, é o senhor da terra. Pragmaticamente é claro que esta é a nova informação, então o predicado é José, já que o assunto em comum, sabido entre os interlocutores, é que havia um senhor da terra, mas até este momento não se sabia quem era.

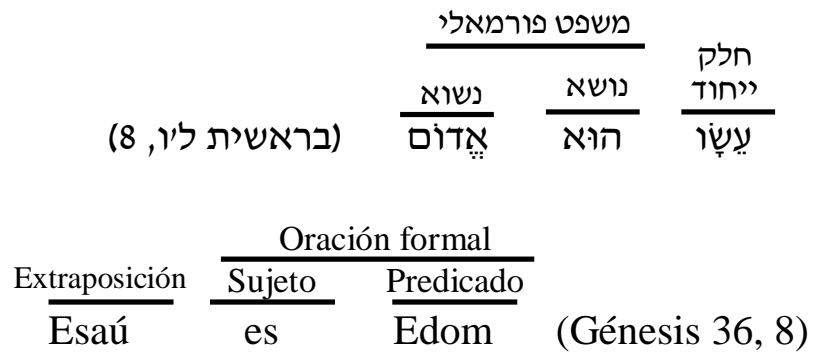

O versículo 8 começa assim: "Y Esaú habitó en el monte de Seir; Esaú es Edom.". Creio que lendo o contexto pode-se ver claramente qual é a nova informação. Fala-se de Esaú em vários versículos e no final nos informam que ele é de "Edom", portanto, este é o novo dado e, logo, será o predicado.

\subsection{2- Modelo 2}

$$
\text { אי- בי הוא - B - B é }
$$

Neste caso, o que muda é a ordem dos componentes na oração. Realizarei uma análise pragmática, tendo em conta o contexto.

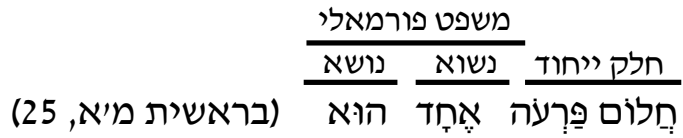

$$
\begin{aligned}
& \frac{\text { Extraposición }}{\text { El sueño de Faraón }} \stackrel{\text { Oración formal }}{\text { Predicado }} \frac{\text { Sujeto }}{\text { uno }} \text { es } \text { (Génesis 41, 25) }
\end{aligned}
$$

Neste caso é muito interessante ver, além do contexto, a tradução para o espanhol. A Bíblia traduz: "El sueño de Faraón es uno mismo". Como durante o capítulo se 
contam os sonhos do Faraó, o que aponta José, que é quem interpreta os sonhos, é que os dois sonhos, que já conhecemos, são um só. Isso deixa claro que a novidade, isto é, o predicado, é a evidência de que os dois sonhos representam um só.

$$
\begin{aligned}
& \text { משפט פורמאלי }
\end{aligned}
$$

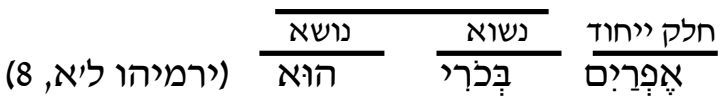

$$
\begin{aligned}
& \text { Oración formal } \\
& \text { Extraposición } \frac{\text { Predicado }}{\text { Efraín }} \frac{\text { Sujeto }}{\text { mi primogénito }} \text { es (Jeremías 31, 8) }
\end{aligned}
$$

Nesta oração, a novidade é o anúncio do primogênito. No mesmo versículo diz "Soy a Israel por padre, y Efraín es mi primogénito". "Efraim" já foi citado no versículo 6, portanto a inovação é que é o primogênito.

\subsection{3-Modelo 3}

Neste terceiro modelo, Driver apresenta a seguinte estrutura:

\section{ב הוא א-}

Este modelo sempre se analisará do mesmo modo, isto é, o B seria o predicado, a nova informação, logo o pronome pessoal (que é traduzido para o espanhol como um verbo de ligação) será o sujeito e ao final o A será a extraposição. Sobre este modelo outros linguistas vão divergir de Driver, já que estes propõem outro tipo de análise. Trarei algumas orações para exemplificar este modelo. Logo explicarei as posturas dos demais pesquisadores sobre este modelo de oração. Driver analisa da seguinte maneira:

$$
\text { צְִּּיק משפט פורמאלי }
$$

\section{Oración formal}

Predicado SujetoExtraposición

Justo $\frac{\text { es }}{\text { Dios }}$ (Lamentaciones 1, 18)




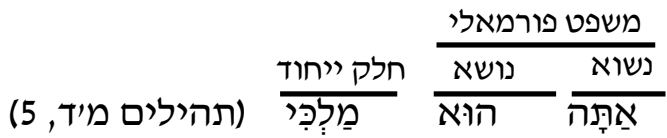

\begin{tabular}{|c|c|c|c|c|}
\hline \multicolumn{2}{|c|}{ Oración formal } & \multirow[b]{2}{*}{ Extraposición } & & \\
\hline \multirow{2}{*}{$\frac{\text { Predicado }}{\text { Tú }}$} & Sujeto & & \multirow{2}{*}{\multicolumn{2}{|c|}{$($ Salmos 44, 5) }} \\
\hline & eres & $\overline{\text { mi rey }}$ & & \\
\hline & & & מאלי - - - - - - 1אלי & 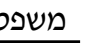 \\
\hline & & זלק ייחוד - - יח & 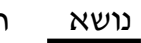 & 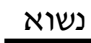 \\
\hline \multicolumn{2}{|c|}{ (שיר השירים ו', 9) } & יוֹנָתִתי & הִיא & אַחַת \\
\hline
\end{tabular}

Oración formal

$\overline{\frac{\text { Predicado }}{\text { Una }}} \frac{\text { Sujeto }}{\text { ex }} \frac{\text { Extraposición }}{\text { mi paloma }}$ (Cantares 6,9)

A este modelo se opõe Carl Brockelmann ${ }^{104}$, já que considera que a análise de Driver não é precisa. Segundo Brockelmann, o pronome "Él" (הוא) será uma cópula (אוגד) e não o sujeito. Desta maneira a análise proposta seria:

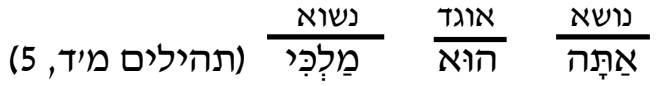

$$
\begin{aligned}
& \frac{\text { Sujeto }}{\text { Tú }} \frac{\text { Cópula }}{\text { eres }} \frac{\text { Predicado }}{\text { mi rey }(\text { Salmos } 44,5)}
\end{aligned}
$$

A causa deste argumento é que, se a análise de Driver é a correta, a oração formal seria "Tú eres" - "אתה הוא", ficando, em hebraico, dois pronomes pessoais sem concordância entre eles e não se obteria uma oração.

Outro que não concorda com este modelo proposto por Driver é Bolozky ${ }^{105}$. Segundo ele, o fato de haver uma extraposição no final da oração é até ilógico, já que a extraposição funciona chamando a atenção do ouvinte, enfatizando. Portanto, não se

\footnotetext{
${ }^{104}$ Ver Brockelmann, Págs. 26-27.

${ }^{105}$ Ver Bolozky, Pág. 18.
} 
justifica que apareça no final. Segundo ele, o sujeito que propõe Driver seria um sujeito oculto, como o elemento pleonástico IT em inglês, e a extraposição proposta por Driver, isto é, o final da oração, será uma aposição do sujeito oculto.

$$
\begin{aligned}
& \text { נשוא }
\end{aligned}
$$

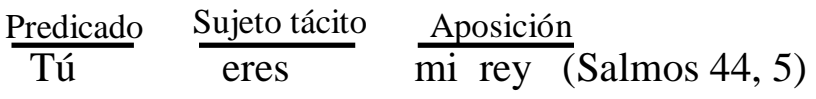

\section{2- Casos de Extraposiç̃o especiais. Estruturas não esperadas}

\subsection{Orações cuja oração formal começa com conjunção coordenativa " $E$ "}

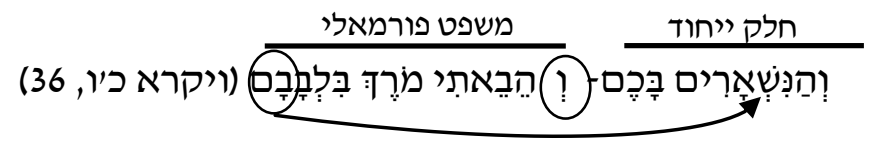

Y a los que queden de vosotros yensus corazones infundiré cobardía (Levítico 26, 36)

Todo hombre o animal que se halle en el campo, yno sea recogido a casa, y el

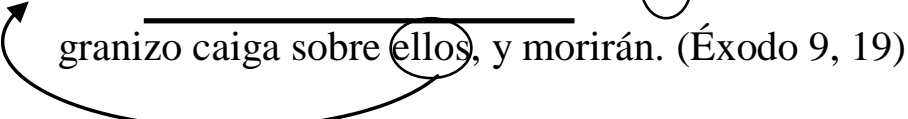



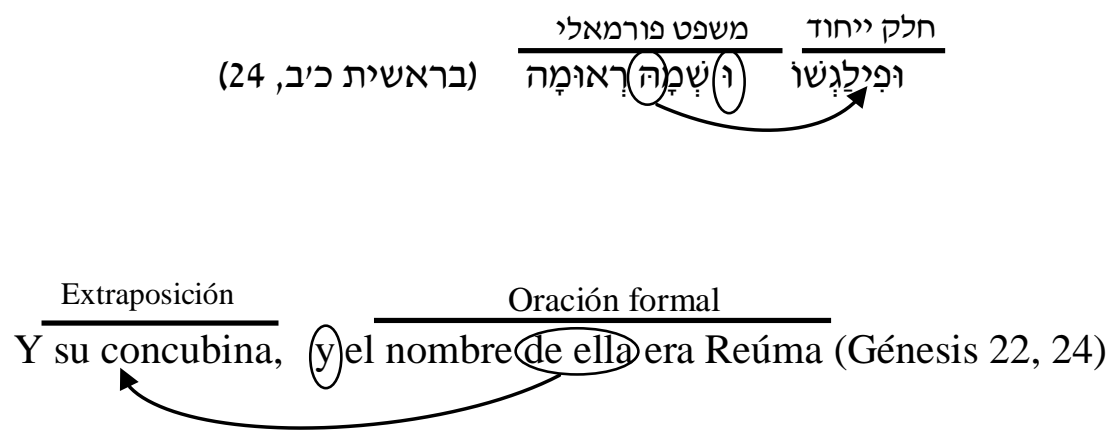

2.2 Orações onde a preposição da extraposição se repete na oração formal

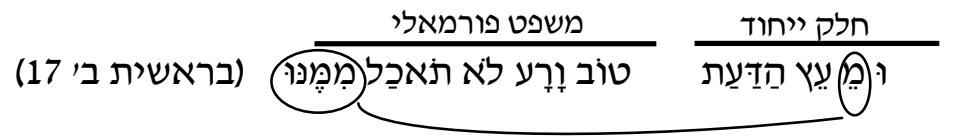

Extraposición

Oración formal

Y (del)árbol de la ciencia, el bien y el mal no comerás de êl) (Génesis 2, 17)

$\mathrm{Na}$ estrutura profunda destas orações, o componente que se extrapõe contém uma preposição e ficaria incorreto se no rastro a preposição desaparecesse. Para que o rastro e o elemento extraposto estejam coindexados, é necessário manter a preposição.

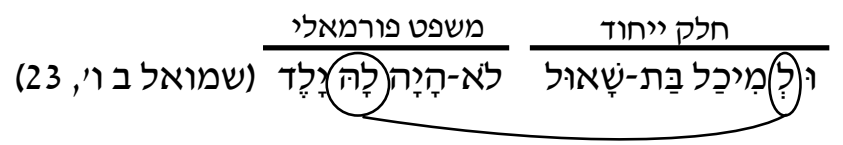

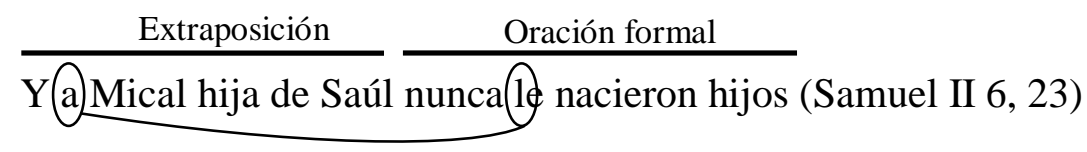


Ainda que a tradução para o espanhol não reflita o que ocorre em hebraico, podemos ver em hebraico que o mesmo pronome se mantém tanto na extraposição como no rastro.

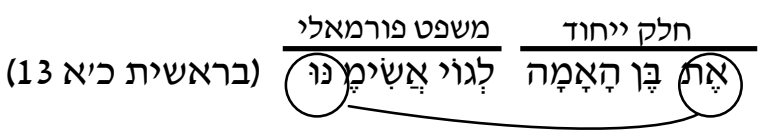

\section{Extraposición Oración formal}

(De) hijo de la sierva una nación haréde él (Génesis 21,13)

Neste caso, em hebraico aparece a forma preposicional anexada ao verbo e, ainda que

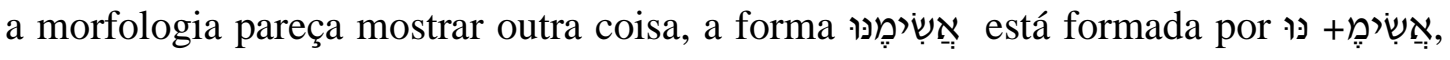
que seria o mesmo que אֶשׁימֶֶ, אותו.
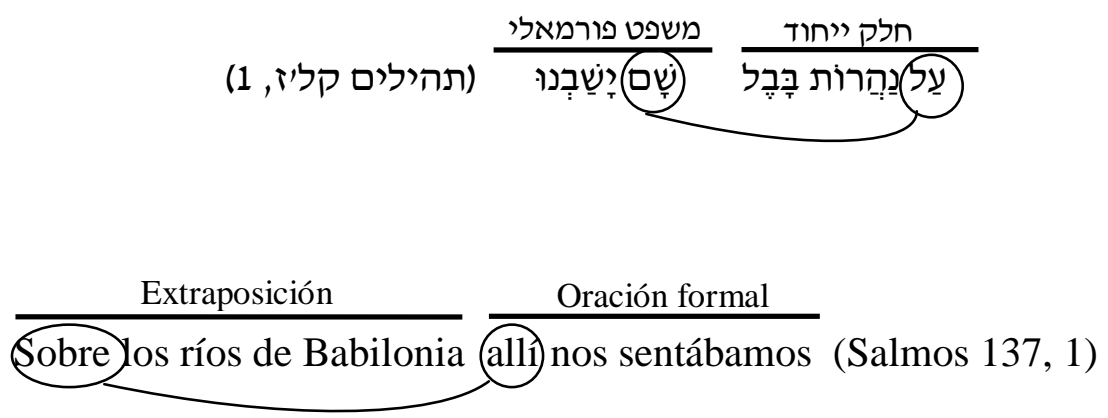

Coloquei este exemplo, já que considero que a preposição "sobre" está substituída pelo adverbio "allí", isto é, eles estão coindexados.

\subsection{O núcleo da extraposição e o rastro são a mesma palavra.}

O motivo desta tautologia pode dever-se à necesidade do falante em enfatizar novamente a palavra ou talvez, como o rastro ficou muito longe da extraposição, é necessário que se repita.

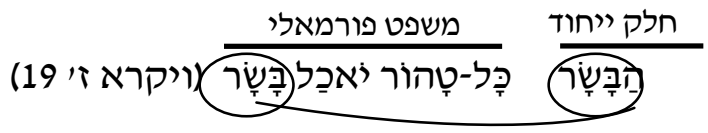


Y la carne que tocare alguna cosa inmunda, no se comerá lac carne (Levítico 7, 19)

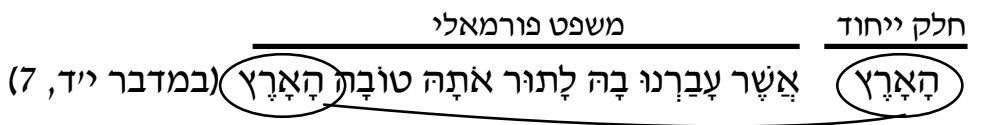

Extraposición

Oración formal

La tierra por donde pasamos para reconocerla, es buena (a tierra (Números 14, 7)

2.4 Orações onde há mais de um caso dos três citados.

Na próxima oração há uma mescla de A e de C. A oração formal começa com a conjunção coordenativa “E”+ repetição de um membro da extraposição na oração formal.

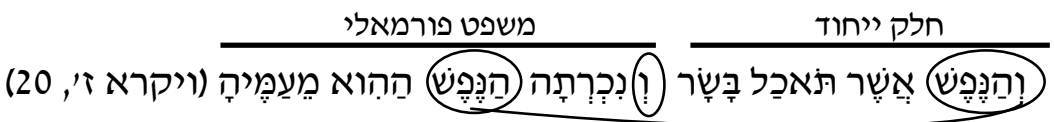

Extraposición

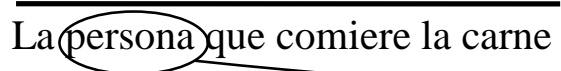

Oración formal

(y) será cortada aquellapersona de entre su pueblo

(Levítico 7. 20)

A seguinte oração é uma mescla de A e de B. A oração formal começa com a conjunção coordenativa "E”+ a preposição da extraposição que se repete na oração formal.

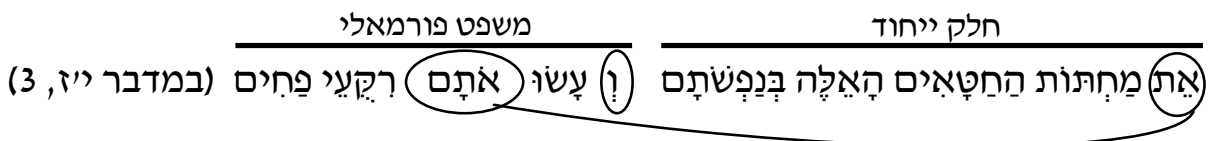


Los incensarios de estos que pecaron contra sus almas

Y harán de ellosplanchas batidas (Números 17,3)

Os exemplos identificados até o momento foram colocados para exemplificar as categorias explicadas. Agora citarei mais exemplos para mostrar que este fenómeno aparece com muita frequência na literatura bíblica.

\section{3- Outros exemplos de Extraposição na Bíblia}

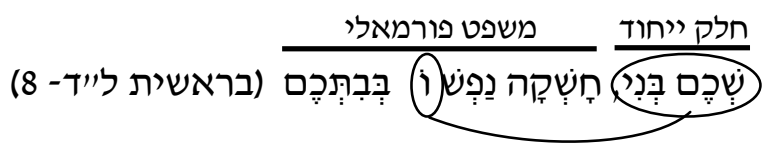

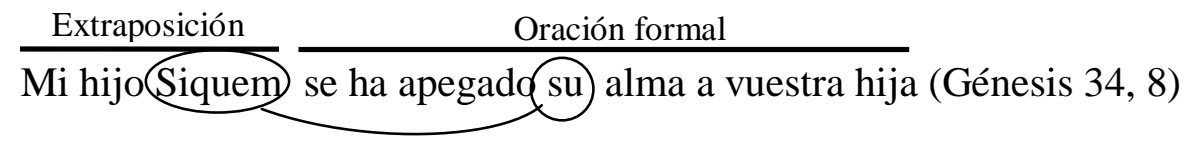

Neste caso, atribui-se a posição de sujeito psicológico ao protagonista da história enfatizando seu nome, porque Siquem violou uma mulher (vuestra hija), pois a amava. Seu objetivo era unir as duas famílias.

A estrutura profunda seria:

El alma de mi hijo Siquem se ha pegado a vuestra hija- נפשו של שכם בני חשקה בבתכם

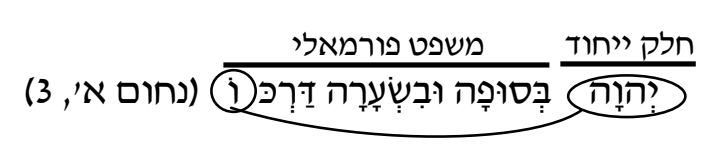

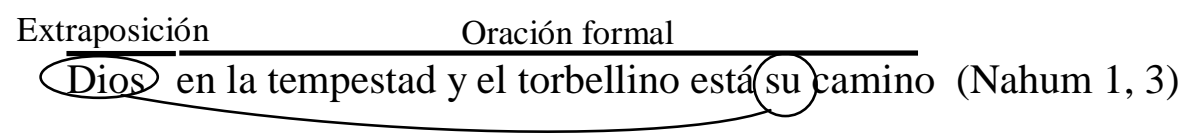


Este versículo enfatiza, por um lado, as características de Deus e, principalmente, que o caminho de Deus é especial. De fato, a continuação do versículo o esclarece ainda mais dizendo que las nubes son el polvo de sus pies.

A estrutura profunda seria:

בסופה ובשערה דרך הי -En la tempestad y el torbellino está el camino de Dios

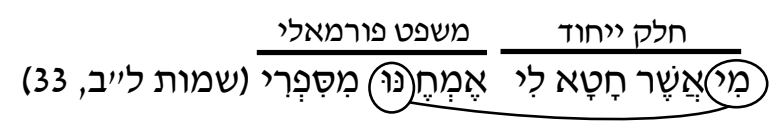

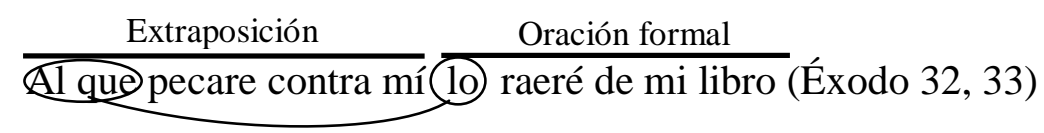

Neste caso se extrapõe "ao pecador". É a maneira de deixar bem clara a advertência. Por outro lado, este já foi mencionado anteriormente.

A estrutura profunda seria:

Raeré de mi libro al que pecare contra mí - אמחה מספרי את מי אשר חטא לי

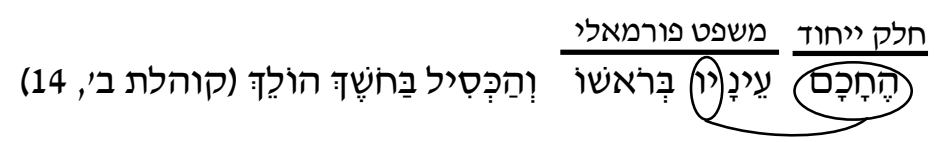

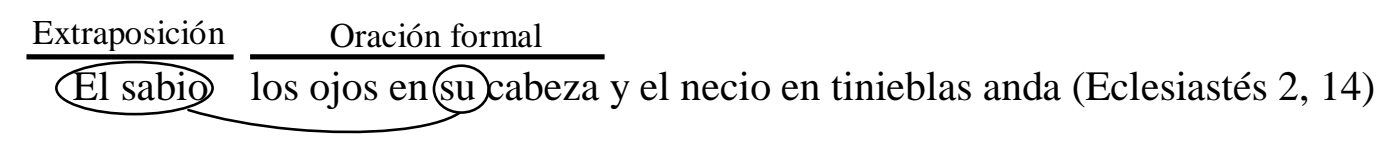

Pode ver-se aqui que a informação fornecida está trocada. Os protagonistas se colocam no principio da oração e, desta maneira, compreende-se melhor a vantagem do "sabio" em comparação com o "necio". Caso não estivesse extraposta, a oração, em sua estrutura profunda, seria a seguinte:

- Los ojos del sabio están en su cabeza y el necio en tinieblas anda - עיניו של החכם בראשו והכסיל בחושך הולך 
Neste caso não se poderia apreciar a oposição entre os protagonistas. Inclusive, na segunda parte do versículo, estão invertidos o predicado e o circunstancial de lugar para que concorde em seu formato com a primeira parte, onde primeiro se nomeia o lugar e, em seguida, o predicado.

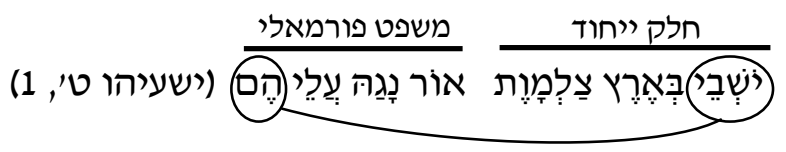

Extraposición $\quad$ Oración formal

Los que moran en tierra de sombra de muerte, luz resplandeció sobre ellos)(Isaías 9, 1)

O objetivo desta extraposição é gerar um paralelismo com a primeira parte do versículo. Para detalhar mais ainda este assunto, vou mostrar todo o versículo para exemplificar isto.

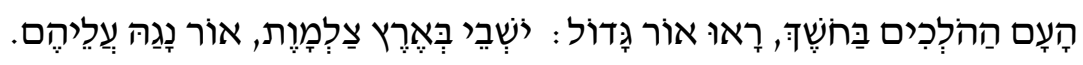

El pueblo que andaba en tinieblas vio gran luz; los que moraban en tierra de sombra de muerte, luz resplandeció sobre ellos

Para mostrar o paralelismo a que me referi, o grafá-lo-ei da seguinte forma:

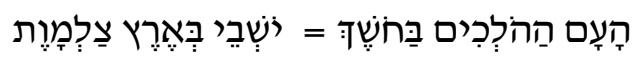

El pueblo que andaba en tinieblas = los que moraban en tierra de sombra de muerte

Podemos ver que, nestas duas partes, nos ensinam quem serão os submetidos ao castigo, sendo a segunda parte a que nos informa o que acontecerá com eles.

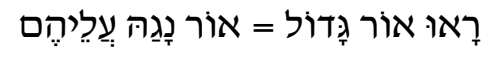

Vio gran luz = luz resplandeció sobre ellos 
Se a segunda oração não estivesse extraposta, não haveria paralelismo, já que ficaria da seguinte forma:

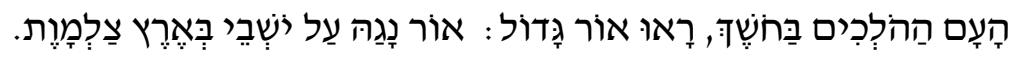

El pueblo que andaba en tinieblas vio gran luz; luz resplandeció sobre los que moraban en tierra de sombra de muerte

Como se pode observar, não ficariam relacionadas sintaticamente. É por isso que se extrapõe esta parte da oração.

No seguinte versículo, podemos observar também uma extraposição gerada com o fim de estabelecer um paralelismo.

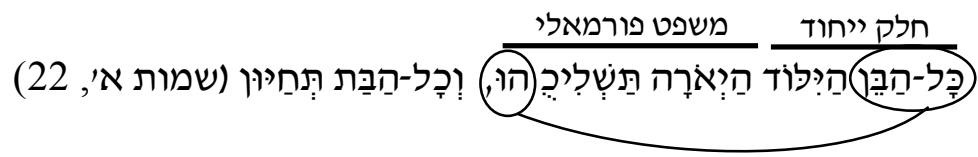

Extraposición Oración formal

Todo hijoque nazca echad(10 al río, y a toda hija preservad la vida (Éxodo 1, 22)

Neste exemplo, também há extraposição com o objetivo de manter um paralelismo entre a primeira e a segunda parte do versículo. Só que desta vez não é somente uma questão de posições: há também influência na relação entre "el hijo" e "la hija", entre "echarlo al río" e "morir", entre as duas consequências de acordo com o gênero do filho.

Sem extraposição, a oração profunda seria:

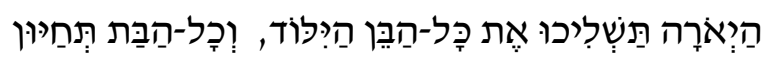

Echad a todo hijo que nazca al río, y a toda hija preservad la vida

Ficando assim a oração, não se daria este jogo de palavras entre o menino e a menina e entre a vida e a morte. 


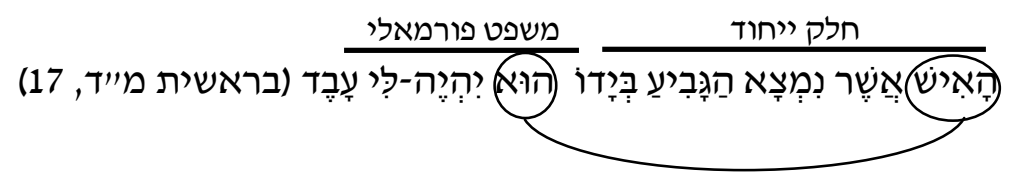

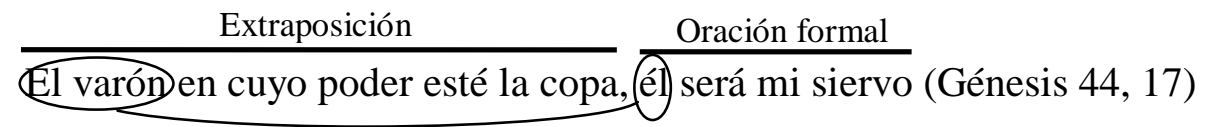

A ideia de realizar esta extraposição é manter no leitor a tensão: isto é nomeia-se e descreve-se "o varão", até chegar ao veredito, ao que é importante.

A história conta que os irmãos, diante da situação do roubo da taça, dizem a José (יוסף) que matem o culpado. Quando ouvem que quem roubou a taça foi Benjamin, o irmão mais novo, todos os irmãos se oferecem como escravos, com o objetivo de deixar o irmão livre e não matá-lo. José, ouvindo isto e, cumprindo seu plano, diz que o homem que roubou a taça, ele e somente ele será o culpado e não os demais irmãos. Para reforçar isto, extrapõe-se o assunto do culpado e deixa-se como rastro o pronome "él" reforçando a exclusividade da culpa e assim os demais irmãos poderiam voltar para o pai.

A oração profunda é:

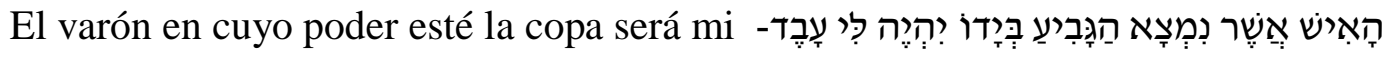
siervo

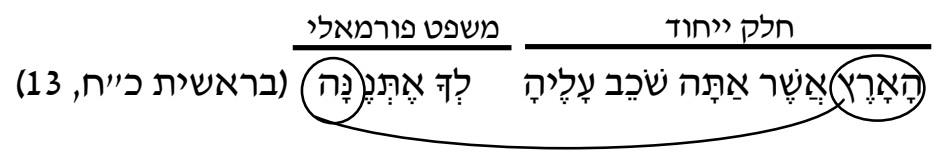

Extraposición $\quad$ Oración formal

La tierra que estás acostado te (a)daré (Génesis 28, 13) 
Aqui também se gera uma tensão, já que não se sabe até o final o que acontecerá com a terra.

A estrutura profunda é:

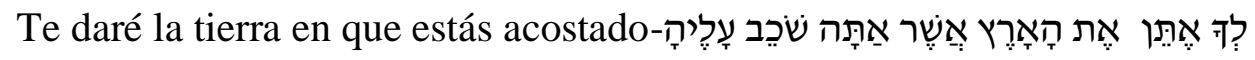

$\mathrm{Na}$ estrutura profunda pode-se ver que não há mistério, já que este é revelado desde o começo: já se sabe o que se fará com a terra. Extrapondo la tierra, gera-se tensão até o final. Somente ao terminar a oração, sabemos o que se dará com la tierra.

Como último caso, gostaria de mostrar um versículo do libro de Salmos. Neste versículo há uma extraposição de estilo, para gerar um paralelismo por um lado, mas, além disso, se acentua o lugar de Deus.

O interessante é que segundo o que se vê, parece que nas duas partes do versículo há extraposição, mas não é assim.

Vou escrever este versículo para que se veja claramente o que estou tentando mostrar e logo explicarei por que a primeira parte está extraposta e a segunda parte não.

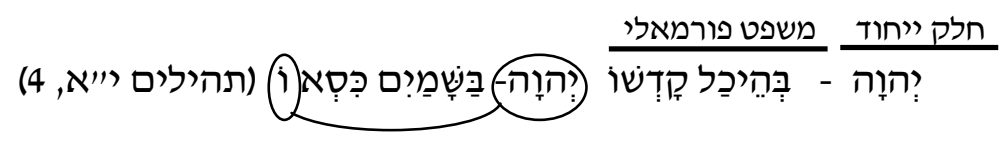

Dios- en su templo santo;Diosen el cielosu trono (Salmos 11, 4)

A primeira parte do versículo é muito parecida com a segunda, só que na primeira não há extraposição. Isto se pode ver pela morfologia, já que abaixo da palavra הִיכַל aparece uma vogal pequena, isto é, o "patach" no lugar de "kamatz". Entende-se, então, que estamos diante de um fenómeno chamado "Smichut" ou estado 
construto $^{106}$. O substantivo em estado construto nunca levará artigo. Mas, na tradução, a palavra em estado construto não pode ser indefinida, se a palavra em estado absoluto é definida; isto é, ou os dois estados são definidos ou os dois são indefinidos. No caso de haver Smichut, não haverá extraposição, já que estas palavras são inseparáveis e, se houvesse uma estrutura profunda, esta oração se poderia extrapor se fossem realocadas as duas palavras e não somente uma. Neste caso, é a morfologia que estabelece a ausência de algum elemento extraposto.

De fato, o motivo para a extraposição é para combinar a estrutura das duas partes, portanto, uma destas partes não estava extraposta.

Segundo a estrutura profunda, este versículo seria:

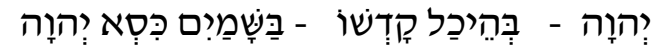

Dios- en su templo santo; en el cielo el trono de Dios

Como se pode ver, este formato não estabelece um paralelismo, portanto, decidiu-se extrapor o que se poderia em termos sintáticos para obter uma oração similar.

\section{4- Conclusão parcial e avaliações}

A Bíblia é a principal fonte da gramática hebraica. Todo fenômeno linguístico que aparece nesta linguagem será parte da gramática hebraica. Já durante esta época o hebraico era uma língua viva. Como consegui mostrar, a extraposição é um fenômeno sintático recorrente. Podemos ver que se extrapõe o sujeito, o predicado, os modificadores, os objetos e os circunstanciais. Podemos encontrar também estruturas diversas dentro deste fenômeno, o que o faz mais comum ainda, demonstrando que seu uso não contraria a regra. Desta forma, posso afirmar que a extraposição é parte da gramática hebraica e, como tal, deve ser considerada como parte da língua padrão e não como exclusiva do registro baixo da língua.

\footnotetext{
${ }^{106} \mathrm{O}$ estado construto ou status constructus é a forma que adota um substantivo ou adjetivo em muitas línguas semíticas, como o árabe ou o hebraico, para expressar uma relação de caso genitivo (é um caso dos substantivos que indica que um nome é um complemento nominal de outro).
} 


\section{Capitulo 5- Sintaxe talmúdica}

\section{1- A Extraposição na Mishná em termos gerais}

Na Mishná também existe a extraposição. Ainda que este fenômeno já tenha sido explicado, para entender o que ocorre na Mishná é necessário enfocar a análise agregando novos conceitos e recordando outros. A extraposição pode ser analisada, basicamente, tendo em conta três condições para sua conformação. Considero importante levar em consideração estas condições, antes mencionadas, para facilitar a análise que proponho neste capítulo.

1 - Em termos de entonação, uma oração extraposta se divide em duas partes, isto é, há uma interrupção entre a parte extraposta ou sujeito de conteúdo ${ }^{107}$ da oração (tema ou topic) e a segunda parte que seria a oração matriz ou predicado de conteúdo (o comentário ou comment) ${ }^{108}$, quando a primeira parte é muito enfatizada ${ }^{109}$.

2- O sujeito psicológico, a parte extraposta será uma frase substantiva ou preposicional $^{110}$.

3- Na oração matriz, de onde sai o membro extraposto, deve haver um componente (rastro) que se refira ao sujeito psicológico e que concorde em gênero e número com ele $^{111}$. Esta condição é a responsável por permitir, em qualquer circunstância, posicionar a extraposição no lugar do rastro, e, desta maneira, obter uma oração

\footnotetext{
${ }^{107} \mathrm{O}$ tema, que é a parte geral do que se fala e do que se supõe um conhecimento prévio por parte dos interlocutores, e o rema ou comment é o que se diz do tema, trazendo informação nova.

$\mathrm{O}$ conceito surge pela primeira vez em meados do século XX das mãos dos linguistas da Escola de Praga, que se preocupavam com o aspecto sóciocomunicativo da linguagem.

${ }^{108}$ Em hebraico, a terminologia Topic e Comment foi apresentado por Rozen, Cap. 32, Pág. 758, com a tradução sujeito conteúdo e predicado conteúdo, ainda que o significado correspondesse mais a Given (informação dada) e New (informação nova).

${ }^{109}$ Azar 1976, Pág. 84- 86. Em orações com extraposição enfatizada, como דוד, הוא המלך o "David, é o rei", a extraposição não é o sujeito de conteúdo da oração já que não é David o principal da oração: fala-se mais do rei, cujo nome é David. Neste tipo de orações não convém falar de sujeito de conteúdo, senão de informação dada, já que David é a única informação, até a enunciação da oração, que se conhece.

${ }^{110}$ Uma preposição + uma frase substantiva.

${ }^{111} \mathrm{O}$ mecanismo para determinar a concordância entre o rastro e o elemento extraposto é chamada coindexação.
} 
normal $^{112}$ ou, como já disse no capítulo da Bíblia, obter a oração em sua estrutura profunda. Esta modificação anularia a estrutura extraposta transformando-a em uma oração "normal”. Por exemplo:

קיץ וחורף- אתה בראתם -

אתה בראת קיץ וחורף - Tú creaste el verano y el invierno

\section{2- Extraposicão Simulada}

Estas orações cumprem as duas primeiras condições, mas não, a terceira. A estas orações Azar chamou "Extraposição Simulada"13", já que são iguais àquelas com extraposição normal, só que o rastro não se refere diretamente ao núcleo do componente extraído, senão que está coindexado com outro membro do sujeito psicológico. Alguns exemplos:

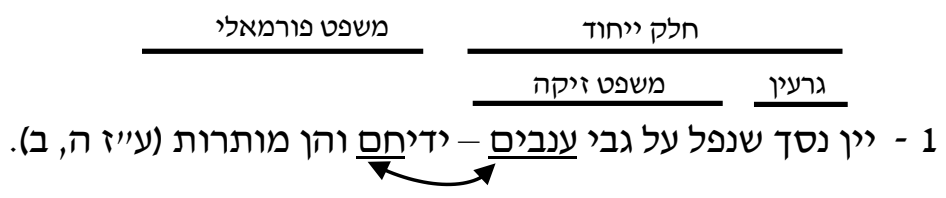

Extraposición

1- Un vino impuro que cae sobre otras uvas- hay que lavarlas y serán permitidas.

Oración formal (Avoda Zará 5, 2).

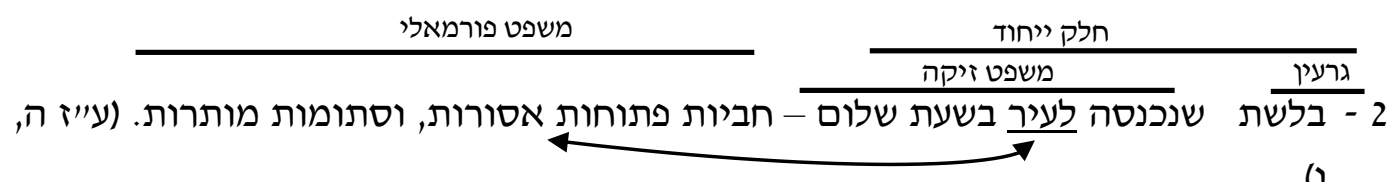

\footnotetext{
${ }^{112}$ Givon e outros afirmam que toda oração com extraposição é somente uma derivação de uma oração normal, isto é, da oração se retirou um componente para enfatizá-lo.

${ }^{113}$ Ver Azar 1982, Pág. 265.
} 


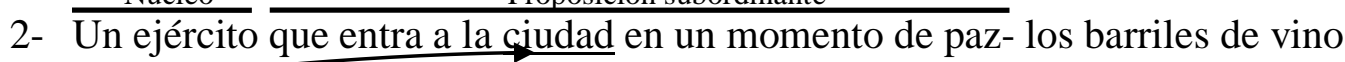

Oración formal

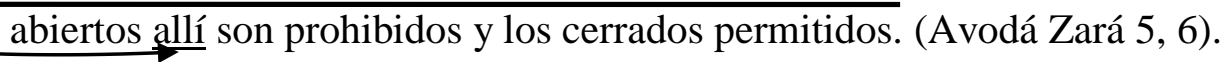

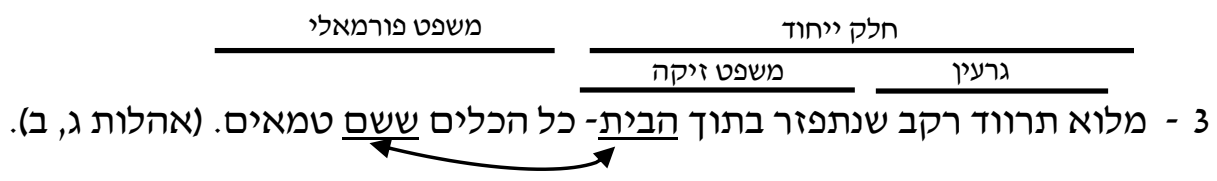

Extraposición

Núcleo

Proposición subordinante

3- Una cuchara con desechos humanos que se desparrama por la casa- todas las

Oración formal

herramientas que están allí quedan impuras. (Oholot 3, 2).

$\mathbf{k}$
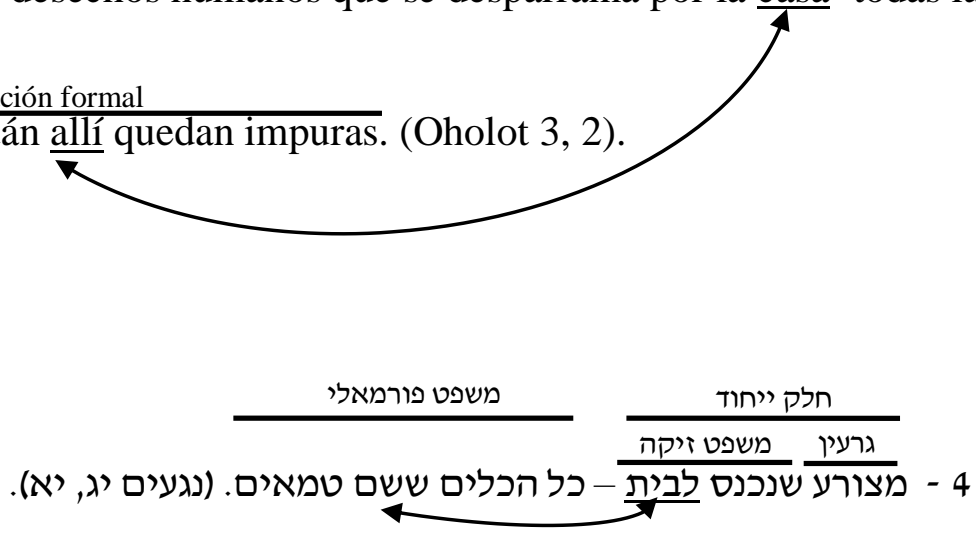

Extraposición Oración formal

Núcleo Proposición subordinante

4- El leproso que entra a la casa- todas las herramientas que están allí serán

impuras. (Negaim 13, 11). 


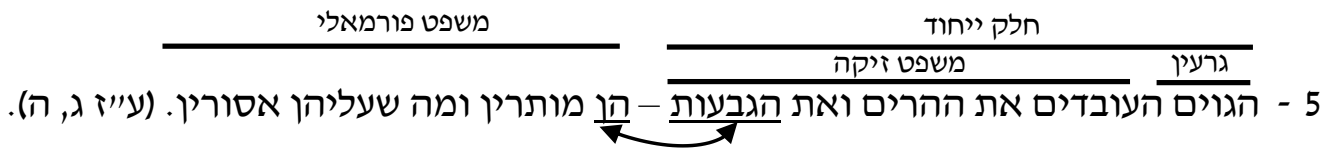

Extraposición

Oración formal

Núcleo

Proposición subordinante

5- Los paganos que trabajan los montes y las colinas- ellas están permitidas, mas lo

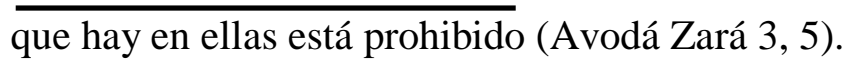

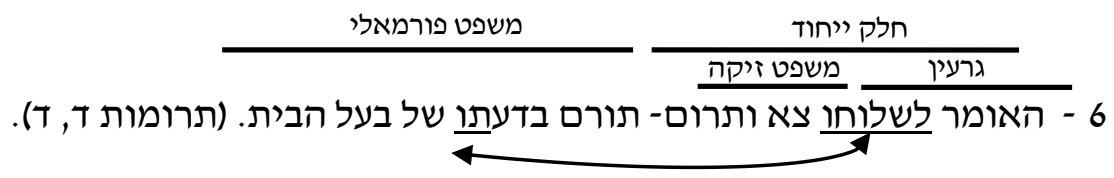

Extraposición

6- El que le dice a su envia do que salga y ofrezca- éste está ofreciendo en

6- El que le dice a su envia do que salga y ofrezca- éste está ofreciendo en

Oración formal

nombre del dueño de la casa. (Trumot 4,4 ).

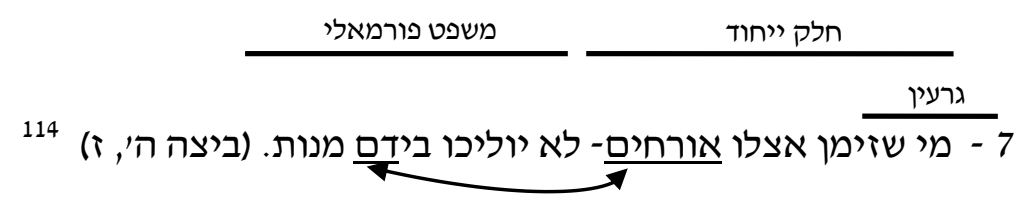

Extraposición

Oración formal

Núcleo

7- El que convoca invitados- no llevaran con ellos porciones de comida. (Bitzá 5, 7)

\footnotetext{
${ }^{114}$ Neste caso a extraposição é uma proposição relativa em si, só que o rastro da oração matriz não está coindexada com o núcleo da extraposição.
} 
Estas orações são muito similares àquelas com o tipo de extraposição que já $\operatorname{conhecemos}^{115}$, mas não é assim já que não há nenhum rastro na oração matriz que se refira ao núcleo do membro extraposto. $O$ rastro se refere a um componente da proposição que complementa o núcleo do sujeito psicológico, ou a algum outro componente, mas não o núcleo.

$\mathrm{Na}$ oração 1 a palavra "lavarlas" não se refere a "vino" (que é o núcleo da extraposição) senão a "uvas", um componente da proposição que complementa o núcleo do sujeito psicológico, e por isso não poderíamos substituir a extraposição pelo o rastro existente, já que não obteríamos a oração em sua estrutura profunda e não se cumpre a terceira condição. Isto ocorre também com os demais dos exemplos antes expostos. Para obter orações comuns, as trocas são demasiado complexas. Não seria suficiente substituir componentes uns pelos outros. Devem-se realizar modificações sintáticas, isto é, trocar a posição dos componentes ${ }^{116}$. Por exemplo, a oração 1 poderia modificar-se da seguinte maneira:

ידיח את הענבים שנפל על גביהם יין נסך והן מותרות Lavar las uvas que cayeron sobre ellas vino impuro y serán permitidas.

Neste caso, a oração deixaria de estar extraposta, mas não se obteria a oração em sua estrutura profunda, isto é, não se obteve esta oração cumprindo a terceira condição antes mencionada.

\section{1- A condição na extraposição simulada}

Muitos pesquisadores $^{117}$ já analisaram o lado semântico das proposições que complementam a extraposição simulada (relative clauses o משפטי זיקה), como em

\footnotetext{
${ }^{115}$ Segal (Págs. 245- 246), vê na oração 6 uma extraposição sem rastro; simplesmente não acredita que há que tratá-la como uma oração diferente daquelas em que não há rastro.

${ }^{116} \mathrm{Na}$ Bíblia há estruturas similares, mas muito esporádicas, como em Números 5, 10 - "Toda persona que ofrezca para el Sacerdote, para el Sacerdote será"..."איש אשר ייתן לכוהן לו יהיה. (במדבר ה, "אי ")

${ }^{117}$ Segal Pág. 121, Peretz Pág. 145 em diante, Bendavid Pág. 614.
} 
quase todas as orações aqui citadas: Estas proposições expressam condição. A condição aparece geralmente em uma proposição subordinada de condição, mas, às vezes, em um entorno adequado, a condição pode tornar-se nominal e, neste caso, poderá apresentar-se, não só como sujeito ou extraposição, senão também como o sujeito de uma extraposição simulada $^{118}$, sendo o Sujeito de Conteúdo da oração, como todas as proposições condicionais, que aparecem no começo de uma oração.

Existem três condições que possibilitam transformar uma proposição subordinada condicional em uma frase substantiva condicional:

a. O sujeito da subordinada condicional deve ser genérico, isto é, deve se referir ao geral e não ao particular ${ }^{119}$. Exemplos:

- Si tres comieren juntos, deben agradecer. = Tres que comieren juntos, deben agradecer (Berachot 7, 1) אם שלושה אכלו כאחד, (הם) חייבים לזמן = שלושה שאכלו כאחד חייבין לזמן (ברכות ז, א).

- Si alguien pasa delante del arca, no responderá ante los Sacerdotes Amén. = Alguien que pasa delante del arca, no responderá delante de los Sacerdotes Amén (Berachot 5, 4).

- אם מישהו עובר לפני התיבה, לא יענה אחר הכהנים אמן = העובר לפני התיבה, לא יענה אחר הכהנים אמן (ברכות ה, ד).

Comparando as seguintes orações:

- Si Rubén pasa delante del arca, no responderá ante los Sacerdotes Amén $\neq$ Rubén, que pasa por delante del arca, no responderá delante de los Sacerdotes Amén.

Esta última oração tem sentido semanticamente, mas seu valor semântico não é igual ao da oração com extraposição simulada, já que Rubén não é um nome genérico.

\footnotetext{
${ }^{118}$ Haiman explica que, se a proposição condicional encabeça a oração, esta será o sujeito de conteúdo, já que traz um contexto especial que dá base para expressar o conteúdo da parte que continua.

${ }_{119}$ Segal (Pág. 221), infere que a conjunção subordinante "que" (she- ש em hebraico) que encabeça uma proposição subordinante, corresponde ao "Se condicional" (Im- אם em hebraico), assim como na Bíblia será a conjunção "Ki" (כ).
} 
b. A proposição substantiva condicional deve aparecer no começo, na função de sujeito de conteúdo.

c. $\quad$ O predicado de conteúdo deve incluir um elemento que se refira a um dos membros do sujeito de conteúdo condicional.

São possíveis 3 tipos de orações:

1- O sujeito de conteúdo condicional é o sujeito gramatical da oração (os exemplos são os da condição A).

2- $\quad$ O sujeito de conteúdo condicional é a extraposição. Exemplo:

世ija de IsraeDque se casó con un Cohen...- no comerán uss siervos su donación. (Yevamot 7, 3)

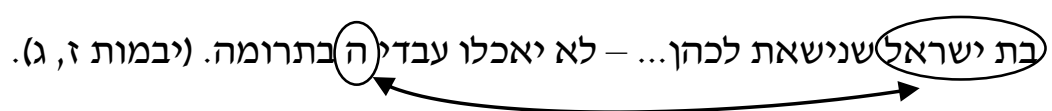

3- $\quad$ O sujeito de conteúdo condicional é uma extraposição simulada (os exemplos são as orações 1-6).

É inviável um quarto tipo, no qual não haja nenhum rastro que se refira ao sujeito de conteúdo. Por exemplo:

- * Los estudiantes que no presenten sus trabajos a tiempo, renunciaré a la Universidad.

ـ * סטודנטים, שלא יגישו את עבודותיהם בזמן, אתפטר מן האוניברסיטה.

Porém é possível:

- Si los estudiantes no presentan sus trabajos a tiempo, renunciaré a la Universidad. - אם סטודנטים לא יגישו את עבודותיהם בזמן, אתפטר מן האוניברסיטה.

Resumindo até aqui, podemos dizer que a extraposição simulada é um caso particular de um fenômeno geral, que é a transformação de uma proposição subordinada condicional, com um sujeito genérico, em uma proposição substantiva condicional na 
função de sujeito de conteúdo. Muitas vezes o sujeito de conteúdo será o sujeito gramatical, algumas vezes o sujeito de conteúdo e outras vezes nenhum dos dois. Somente compreendendo o conceito de extraposição simulada, podemos entender, por um lado que as orações 1- 7 são corretas e, por outro lado, que a oração como a seguinte não é correta:

* El vino que se derramó sobre la mesa, Rubén la construyó con sus propias manos. * היין, שנשפך על השולחן, ראובן בנה אותו במו ידיו. Embora esta oração não seja correta, pode obter-se dela uma oração normal como: "Rubén construyó la mesa, en la que se derramó el vino, con sus propias manos". "ראובן בנה את השולחן, שנשפך עליו מהיין, במו ידיו"

Se esta oração fosse considerada correta, deveríamos inferir que podemos criar orações extrapostas quando não há possibilidade de permutar, de forma direta e sem modificações extras, o rastro com a extraposição, e igualmente veríamos as orações 17 como orações extrapostas em todo sentido. Agora que podemos ver que esta última oração não é correta ${ }^{120}$, devemos concluir que o que faz com que as demais orações estejam corretas não é o fato de serem parecidas a uma oração extraposta normal, senão que isso se deve a seu valor condicional (ou por apresentar um sujeito genérico).

A condicionalidade do sujeito de conteúdo é a única coisa que permite a construção de orações como as de 1 - 7. A terceira condição, que requer a intervenção de uma unidade coindexante neste tipo de orações, não surge pela necessidade de assemelharse às orações extrapostas comuns, mas surge por sua natureza nominal e o conteúdo comunicativo específico de um sujeito de conteúdo: É inviável começar uma oração em hebraico com um sujeito de conteúdo na forma de frase nominal ${ }^{121}$, cuja função

\footnotetext{
${ }^{120}$ Daqui se pode deduzir que a extraposição deve ser o sujeito de conteúdo, já que em sua posição de sujeito de conteúdo há diferenças entre "el vino que se derramó en la mesa" e "la mesa en la que se derramó el vino". Não existem diferenças entre estas duas orações em uma análise semântica (se há vinho que se derramou sobre a mesa, significa que há uma mesa na qual se derramou vinho).

${ }^{121}$ A frase nominal é um grupo de palavras cujo significado total se refere a um substantivo e suas propriedades combinatórias são idênticas às de seu núcleo (que é um substantivo). Além do que é uma frase que não terá verbo nem cópula.
} 
seja expressar a informação de que se fala, e terminar a oração com uma informação que não foi mencionada anteriormente. Esta é a causa pela qual encontramos o rastro em toda oração extraposta, já que deve fazer menção direta ao núcleo da extraposição, para conservar a extraposição como algo do que se continua falando. Apesar disto, quando o sujeito de conteúdo é uma proposição subordinada condicional (como as orações 1-7), isto é, por um lado, são frases nominais, mas, por outro lado possuem um significado de condição, não há necessidade de mencionar ou recordar o núcleo da frase nominal. O poder de ser condicional lhe é suficiente para anular a necessidade de coindexar com o núcleo, mas não é um poder suficiente para anular todo tipo de rastro, e por isso haverá coindexação com outro componente da frase nominal, e não precisamente com o núcleo.

\subsection{O Se condicional}

Embora pareça que se pode trocar o "que" (ש) nas proposições que expressam condição por um "se" (אם), e o "se" que aparece depois de uma frase substantiva por um "que" 122 vou a expor algumas observações sobre esta regra atravez de alguns exemplos.

a) Se poderia aparecer também depois de um substantivo genérico. Exemplo:

- Rubén, si come la acelga, recibirá un helado.

$$
\text { ראובן, אם יאכל את התרד, יקבל גלידה }
$$

b) Apesar do valor lógico semântico e similar que existe entre um substantivo genérico + que + oração + proposição e entre um substantivo genérico + se condicional + oração + proposição, não há entre eles um conteúdo comunicativo similar: quando aparece um "que", o sujeito de conteúdo será um substantivo genérico + que + oração; quando aparece "se" condicional, o sujeito será o substantivo genérico somente. A oração "Esclavos y pequeños, si fueron pesados, su medida es paralela" (Masechet Shekalim 1, 5) "עבדים וקטנים, אם שקלו, מקבילין מידן é

\footnotetext{
${ }^{122}$ Ver os nomes que aparecem na nota número 11.

123 Não encontrei um exemplo paralelo na Mishná. Talvez se deva à característica legal (de Halachá), que estabelece leis sobre questões gerais e não as estabelece em questões particulares.
} 
de conteúdo lógico semântico similar a "esclavos y pequeños que fueron pesados, su medida es paralela" "עבדים וקטנים ששקלו, מקבילין מידן", mas não em seu conteúdo comunicativo. A primeira oração fala sobre escravos e pequenos e diz sobre eles que, se são pesados sua medida é paralela, e na segunda fala sobre escravos e pequenos, que são pesados, e afirma que sua medida é paralela.

A diferente função do "se" condicional diante do "que", para estabelecer a proposição substantiva que funciona como sujeito de conteúdo da oração, fica demonstrada na formulação haláchica segundo Chazal: quando a Halachá se refere ao aspecto geral das coisas, e diferentes leis operam sobre questões secundárias desse aspecto (ou essas diferentes leis estão condicionadas), ela será formulada geralmente da seguinte maneira: [substantivo genérico (+ que/artigo + oração): (se condicional) $\mathrm{X}_{1}-\mathrm{Y}_{1}$, ((y) se condicional) $\mathrm{X}_{2}-\mathrm{Y}_{2}{ }^{124}$. Por exemplo:

8) Es pecador el que toca el horno: si tocó su mano- impuro, y su pierna puro. (Parah $10,4)$.

- טהור לחטאת שנגע בתנור : בידו - טמא, וברגלו טהור.

9) Las cebollas que cayeron sobre ellas lluvias y florecieron: si estaban sus hojas negras- son prohibidas, si verdes- ellas serán permitidas. (Shviit 6, 3). - בצלים שירדו עליהם גשמים וצמחו: אם היו העלים שלהם שחורים- אסורים, הוריקו- הרי (Shis,

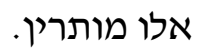

10) Un Nazir que se afeita y es impuro: si la impureza era sabida - es un conflicto, y si nadie lo sabía- no es conflicto. (Nazir 9,2)

- נזיר שגילח ונודע שהיה טמא: אם טומאה ידועה- סותר, ואם טומאת התהום- אינו סותר.

A dupla condição, que aparece depois de um sujeito de conteúdo, começa quase sempre com "e se" (ואם):

\footnotetext{
${ }^{124}$ O que vem antes dos dois pontos será o sujeito de conteúdo; o símbolo “_“ separa tema de rema. Esta sinalização aparece frequentemente no volume H. Albeck and H. Yalon, Shisha Sidre ha-Mishnah. Editorial Bialik, Jerusalém- Tel Aviv, 1956.
} 
11) Una caña de olivo: Si está sujetada en su punta- está contaminada, y si no- no está contaminada. (Shabat 17, 3).

- קנה של זיתים: אם יש קשר בראש ו- מקבל טומאה, ואם לאו - אינו מקבל טומאה.

Neste tipo de orações, não é viável trocar o "que" pelo "se" condicional e o "se" condicional pelo "que", apesar de que, do ponto de vista sintático puro, isto seria possível (às vezes necessitando de uma troca na ordem dos componentes) sem modificar o conteúdo semântico da oração. Isto se deve a que toda troca deste tipo impõe uma modificação na formulação da oração. Na oração 8, por exemplo, se trocamos sua formulação de "Es pecador: si toca el horno con su mano-impuro y (si lo tocó) con su pierna- puro", não mudará nada no conteúdo. Não obstante, obteremos duas orações diferentes se nos referimos à informação que estas transmitem. Na oração 8, o toque do forno é parte da informação dada, acerca da qual se quer renovar algo, e a ela se anexa o "puro en su pecado" com o fim de trazer junto a ele a questão da qual se estava falando (sujeito de conteúdo), enquanto que na outra oração, o toque do forno representa uma parte do que se quer renovar (a lei) e se anexa ao que se vai dizer (sujeito de conteúdo).

c) Nos exemplos do tipo 1-5, nas orações extrapostas simuladas não se pode trocar o "que" pelo "se" condicional ${ }^{125}$. A causa disso é que o "se" condicional produz uma troca no sujeito de conteúdo e transforma o substantivo genérico em sujeito de conteúdo; portanto, o rastro localizado na oração formal não coindexa com nenhum elemento do sujeito de conteúdo. Só coindexará com algum componente da proposição condicional. Como vimos antes, não é possível começar um sujeito de conteúdo em forma de substantivo (ou proposição substantiva) e terminar a oração com outro sujeito.

\footnotetext{
${ }^{125}$ Isto foi revisado na concordância de Kosovski e não foram encontrados exemplos. Não obstante, encontrei na Bíblia: Un hombre que muera en la tienda-cualquiera que entre en la tienda, y todo el

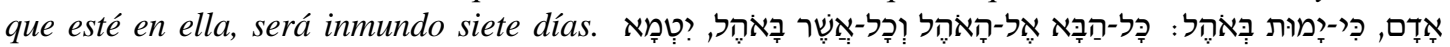
שִשבְעַת יָמִים

Ainda que isto não seja para interpretar o "que" (כי) bíblico analisando o "se" (אם) ou o "que" de Chazal.
} 


\section{3- Exemplos de extraposição simples na Mishná}

Foram trazidos exemplos específicos de extraposição simulada, para exemplificar o fenômeno. Dentro da Mishná podemos encontrar, como já mencionei, muitos outros exemplos de extraposição simples, do tipo que aparece na Bíblia, onde a coindexação é entre o núcleo extraposto e seu rastro. Por exemplo:

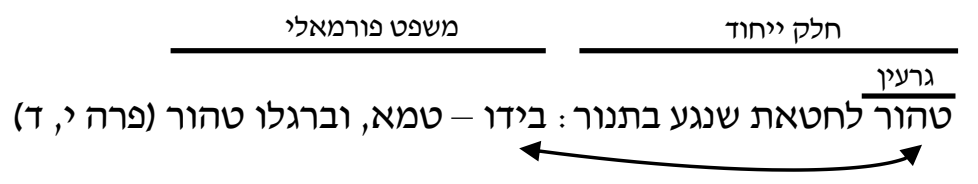

Extraposición

Oración formal

Núcleo

Pecador es el que toca el horno: si toco su mano- impuro, y su pierna puro. (Parah 10, 4)

משפט פורמאלי - (- - n

חלק ייחוד - - - - n - n

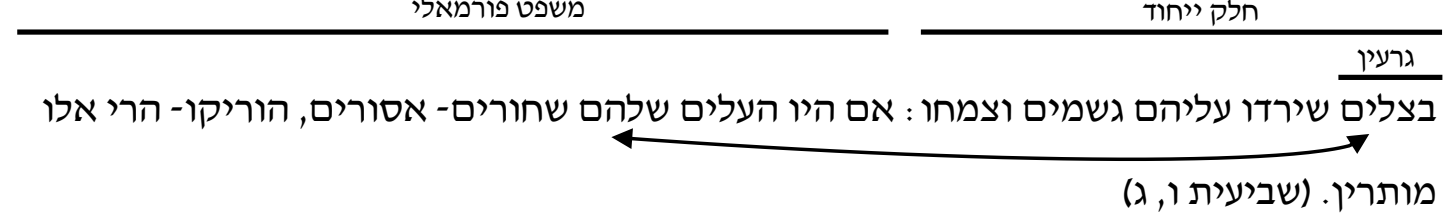

Extraposición

Oración formal

Núcleo

Las cefbollas que cayeron sobre ellas lluvias y florecieron: si estaban sus hojas negras-

son prohibidas, si verdes- ellas serán permitidas. (Shviit 6, 3) 


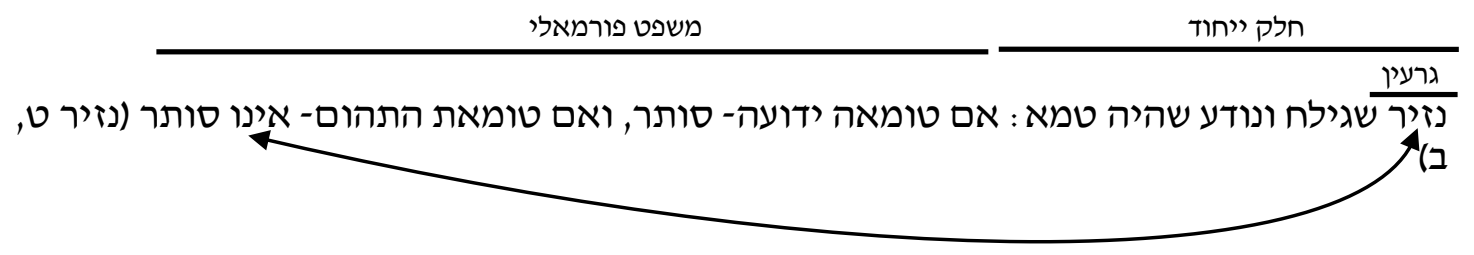

Extraposición

Oración formal

Núcleo

Un Monje que se afeita y es impuro: si la impureza era sabida - es un conflicto, y si nadie lo sabía- él no es conflicto (Nazir 9, 2)

קנה של זיתים: אם יש קשר בראשו- מקבל טומאה, ואם לאו - אינו מקבל טומאה. (שבת יז, ג)

Núcleo

Una caña de olivo: Si está sujetada en su punta- está contaminada, y si no- no está $\longrightarrow$

contaminada. (Shabat 17, 3)

משפט פורמאלי

חלק ייחוד

גרעין

פקק החלון רבי אליעזר אומר בזמן שהוא קשור ותלוי פוקקין בו ואם לאו אין פוקקין בו. (שבת

$(i, i)$ 
El pistillo de una ventana, dice Rabi El'azar, cuando éste está ensimismado y

pendiente se cierra y si no no se cierra. (Shabat 17,7 )

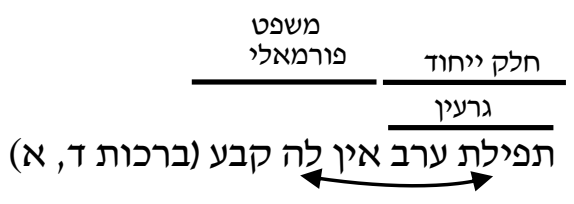

Extraposición Núcleo

Oración formal

El rezo de la tarde éste no está establecido (Berachot 4, 1)

$\longrightarrow$

\section{4- Conclusão parcial e avaliações}

As estruturas extrapostas na Mishná são muito comuns e as estruturas extrapostas simuladas mais ainda, já que, quando a Halachá se refere ao aspecto geral das coisas, e diferentes leis operam sobre questões secundárias desse aspecto de estrutura condicional, a Halachá será formulada geralmente da seguinte maneira: [substantivo genérico (+ que/artigo + oração): (se condicional) $X_{1}-Y_{1}$, ((y) se condicional) $X_{2}-Y_{2}$. Fica claro que o uso de orações extrapositivas na Mishná é comum, tanto como aparecem na Bíblia e, desta forma, podemos afirmar novamente que a extraposição forma parte do sistema gramatical hebraico. 


\section{Capítulo 6- Os judeus do Norte da África}

\section{1- O Magreb}

Como ficou demostrado nesta pesquisa, o fenômeno sintático de extraposição é parte da gramática hebraica, já que aparece nas fontes judaicas, principalmente na Bíblia, e por isso está legitimado. Por outro lado, no hebraico moderno, uma oração com estrutura extraposta é considerada como uma oração pertencente a um registro baixo da língua. Entretanto, se faz parte da gramática do hebraico, por que é considerada como um fenômeno pertencente a um registro baixo do idioma?

Esta é a pergunta principal que conduziu minha pesquisa. Vou esclarecer este ponto neste capítulo. Para este fim, necessito voltar a falar sobre a família Dadón, protagonista do romance "Shum Gamadim lo Iavohu", analisado no capítulo 3. Assim como a família Dadón, vinda do Marrocos, todos os judeus provenientes do norte da África (Tunísia, Marrocos e Argélia) chegaram a Israel depois de se haver declarado o Estado, falando árabe e francês, suas línguas maternas.

Magreb é o nome com o qual se conhece a região do norte da África, que compreende os países de Marrocos, Tunísia e Argélia. O árabe falado no Magreb tem notáveis diferenças com os dialetos árabes orientais, que, por sua vez, se compõe de falas muito diversas. O árabe padrão ou literário é a língua oficial em todos os Estados magrebinos. A segunda língua é o francês em todos os Estados ${ }^{126}$.

Quando falamos do árabe moderno ou padrão, estamos fazendo referência a um registro da língua árabe que começou a formar-se no século XIX. Havia uma grande necessidade nos países árabes, principalmente no Oriente, de adaptar-se aos tempos modernos. Era necessária uma língua mais ágil, menos complicada que o árabe antigo ou o árabe com o qual foi escrito o Corão, para que os árabes pudessem comunicar-se entre eles e para que fosse possível traduzir livros europeus que falavam de novas ciências, não somente científico-tecnológicas senão também literárias. Este registro da língua árabe é o utilizado hoje em dia nos países árabes para escrever livros, publicações na imprensa, ensinar nas escolas e na universidade, comunicar-se entre eles, etc... Enfim, é a língua oficial dos países árabes.

${ }^{126}$ Ver P. Sánchez, Págs. 116- 117. 
No Marrocos, por exemplo, a língua oficial é o árabe moderno e não o árabe marroquino ou alguma de suas variantes. $\mathrm{O}$ árabe marroquino não se escreve, nunca foi escrito. Ao longo da historia utilizou-se o árabe antigo e em tempos mais contemporâneos, o árabe padrão ${ }^{127}$.

O francês, que é a segunda língua utilizada no Magreb, ainda que não apareça na Constituição, é a língua que se emprega na Administração, juntamente com o árabe moderno. Algumas disciplinas universitárias, sobretudo as científicas, são ensinadas neste idioma. Nas grandes cidades, especialmente aquelas que estiveram sob o protetorado francês, este idioma é falado por uma certa classe média-alta que foi educada em francês ou que busca assimilar-se à cultura francesa como forma de aproximar-se da modernidade, sem deixar de ser marroquina. As famílias de classe média-alta costumam enviar os filhos a colégios privados franceses ${ }^{128}$.

\section{2- Árabe e francês magrebino}

O árabe e o francês do Magreb têm suas diferenças nas formas literárias, geralmente, na área fonética e lexical, mas não na sintaxe. Por exemplo, a letra šīn (em árabe شين, šīn, pronunciado como "sh"), que a decima terceira letra do alfabeto árabe, representa um som fricativo palatoalveolar surdo, $1 / \mathrm{g} / \mathrm{Na}$ numeração abyad, esta letra tem geralmente o valor de 300, ainda que no Magreb o valor seja de 1000 .

Como minha teoria está baseada na associação do registro baixo da extraposição em hebraico com o uso deste idioma pelos judeus do norte de África, é necessário conhecer como funciona este fenômeno no árabe e no francês. Na continuação, trarei alguns exemplos e explicações do uso da extraposição nestas duas línguas, para esclarecer que este fenômeno é muito usado e muito comum, tanto no francês como no árabe. É necessário recordar que quando uma pessoa aprende uma nova língua, esta será falada sob influências da língua materna e não me refiro somente à

\footnotetext{
${ }^{127}$ Ver F. M. García, Pág. 16.

${ }^{128}$ Ver F. M. García, Pág. 18.
} 
pronúncia, senão também a palavras, fonemas e até estruturas que serão incorporadas ao novo idioma.

\section{3- A extraposicão no francês}

Para analisar o fenômeno de extraposição em francês e árabe, tive de recorrer à bibliografia em hebraico, inglês ou espanhol por serem estas, e não o árabe ou o francês, as línguas que domino. De qualquer maneira, sendo a extraposição um fenômeno tão comum no árabe e francês, não foi difícil encontrar exemplos e citações em espanhol, hebraico ou inglês.

No francês informal, o deslocamento é um fenômeno muito comum. No jornal podemos encontrar uma oração como "Le chien a mordu la petite fille" (O cachorro mordeu a pequena menina), mas, no francês coloquial esta frase pode reproduzir-se das seguintes maneiras:

Le chien il a mordu la petite fille (El perro, él mordió a la pequeña niña).

La petite fille, le chien (1'a) mordu (La pequeña niña, el perro la mordió).

Existe um tipo de construção, que Bally ${ }^{129}$ denomina a extraposição de "phrase segmentée" ou "dislocation". Ela explica que são as orações nas quais o tema aparece separado formalmente do predicado, o que responde ao propósito de converter em tema um constituinte ou elemento qualquer do enunciado:

“Opomos a segmentação à sintaxe ligada, e comparamos, por exemplo 'Cette lettre, elle ne m'est jamais parvenue' (Esta carta, ela nunca me chegou) e 'Cette lettre ne m'est jamais parvenue' ('Esta carta nunca me chegou'). Descobriremos duas diferenças principais: uma relativa à função, outra, à forma. A segmentação permite fazer de qualquer parte de uma oração ordinária o tema, e do restante o enunciado propriamente dito. Desta maneira 'Je n'arrive pas à résoudre ce problème' se transforma em 'Moi, je n'arrive pas à résoudre ce problème' ou 'Résoudre ce problème, je n'arrive pas' ou 'Ce problème, je n'arrive pas à le résoudre'130,".

\footnotetext{
${ }^{129}$ Ver Bally, pág. 79.

${ }^{130}$ Ver Bally, pág. 80.
} 
Segundo Bally, a função principal desta construção é apresentar aquilo do que se quer falar antes de formular a predicação. "O hábito de separar o tema e 'o propos' na oração também facilita a análise do pensamento; por fim, a sequência progressiva, peça matriz da gramática francesa, consiste em dizer o princípio do que se fala antes de expressar a ideia, que é o objetivo do enunciado ${ }^{131}$ ".

$\mathrm{O}$ deslocamento facilita o processamento sintático e permite "adaptar o enunciado às necessidades do interlocutor e facilitar seu trabalho de interpretação", porque, no francês, é um dos traços mais característicos e chamativos da sintaxe falada ${ }^{132}$.

Le Bidois acolhe as observações de Bally e desenvolve, em um dos capítulos dedicados à ordem de palavras, alguns detalhes sobre as características da construção. Le Bidois utiliza o termo "deslocamento" para referir-se à anteposição ou posposição do complemento direto, indireto ou sujeito, tanto no início como ao final da oração. A construção obedece, segundo os gramáticos franceses, a um procedimento de "colocação em relevo" (em francês "mis en relief"), cuja função é dar maior importância ou proeminência a um elemento oracional determinado. Na gramática de Le Bidois o "deslocamento" se presenta como um fenômeno antigo na língua francesa, testemunhado desde suas origens, muito difundido na língua falada, assim como um procedimento estilístico empregado na língua literária. Assim como Bally, os irmãos Le Bidois observam que o elemento deslocado pode aparecer tanto à esquerda da oração, procedimento que denominam "deslocamento por recuperação", como ao final da oração, no "deslocamento por antecipação". A mais frequente consiste em expressar o objeto no princípio (à esquerda), e repeti-lo sob a forma de um representante: 'Cette femme, je l'ai bien connue' (Esta mulher eu a conheci bem). Inversamente, pode-se anunciar, por meio de um pronome pessoal, o objeto que reservamos para enunciar mais tarde: 'Je l'ai bien connue, cette femme' (Eu a conheci bem, essa mulher) ${ }^{133}$.

Ademais, afirmam que os elementos deslocados desempenham várias funções sintáticas, mas, sobretudo, a de sujeito, complemento direto e indireto, e acrescentam que existem distintas formas de recuperação pronominal do elemento deslocado,

\footnotetext{
131 Ver Bally, pág. 292.

132 Ver Bally, pág. 314.

${ }^{133}$ Ver Le Bidois, págs. 50-51.
} 
como o pronome demonstrativo ou possessivo: "Napoleón, sa campagne de 1813 a été trés contestée" (Napoleão, sua campanha de 1813 foi muito contestada) ${ }^{134}$.

Le Querler, apud Padilla García ${ }^{135}$, estuda os processos de deslocamento e tematização em francês. Ainda que normalmente o deslocamento se associe a um valor temático, Le Querler estuda casos nos quais não há uma referência anafórica. O deslocamento com valor temático, por outro lado, se encontra em uma variedade muito grande de construções e em uma escala variável de graus dependendo da relevância do elemento deslocado dentro do enunciado.

Como explica Perez Bello ${ }^{136}$, além da extraposição à esquerda, fenômeno muito comum nas línguas romances, é característica, também no francês, a extraposição à direita. Como foi explicado no item 5 do capítulo "Fundamentos Teóricos", no deslocamento à direita, o objeto direto, ou qualquer outro complemento do verbo, se situa na parte direita, isto é, na parte que lhe corresponde segundo a ordem não $\operatorname{marcada}^{137} \mathrm{SVO}$, mas aparece antecipado por um pronome que será seu rastro. O tema do enunciado aparece tanto no complemento extraposto como no pronome. Nesta estrutura o que se encontra extraposto é o tema; além disso, ele é introduzido como se fosse conhecido ou dado, ainda que na realidade não o seja, violando, desta maneira, a ordem informativa mais lógica:

\section{E2as tu les hoto, n'est-ce pas?}

Las tienes tú as fotos ¿no? ${ }^{138}$

Tema/Dado Rema Tema/Dado

\footnotetext{
${ }^{134}$ Ver Le Bidois págs. 60-61.

${ }^{135}$ Ver Padilla García, pág. 111.

${ }^{136}$ Ver Perez Bello, pág. 256.

${ }^{137}$ A ordem não marcada se refere à distribuição normal da informação, quando esta coincide com a ordem sintática esperada, no caso do francês SVO (sujeito- verbo- objeto). Quando esta ordem não é o esperado, segundo a sintaxe do idioma, der-se-á que a ordem é marcada.

${ }^{138}$ Ver Perez Bello, pág. 256.
} 
Nos deslocamentos à direita os constituintes deslocados são normalmente elementos conhecidos ou deduzíveis pelo contexto. O que realmente o emissor trata de fazer é enfatizar a possessão de conhecimentos comuns com seu interlocutor. Por isso seu uso, normalmente, se dá em situações comunicativas nas quais os conhecimentos compartilhados entre o falante e o interlocutor são grandes, ou nas quais o conteúdo das mesmas tem uma grande carga persuasiva como, por exemplo, nas mensagens publicitárias:

(2) savourer ici le croissan chaud.

Saboread(10) aquíl croissand caliente ${ }^{139}$

Alguns deslocamentos à direita são uma espécie de adição ao final sem a qual, sem dúvida, o enunciado seria igualmente compreensível. Esta ação que se realiza na mente do falante é conhecida em francês como after thought ${ }^{140}$ : o emissor se dá conta de que a mensagem que lançou pode não resultar completamente compreensível para o receptor e acrescenta a posteriori o constituinte pleno que realiza a função de tema. A alta frequência de uso do deslocamento à esquerda e à direita em francês faz com que ambas estejam perdendo seu caráter marcado e seu valor funcional originário de tal forma que se estão consolidando como uma forma a mais de estruturar o enunciado.

Mostro alguns exemplos que Nadasdi colocou em seu artigo de 1995, de orações com o sujeito extraposto, ocorrência típica de se ouvir em diversas variedades do francês coloquial.

\footnotetext{
${ }^{139}$ Ver Perez Bello, pág. 256.

${ }^{140}$ Ver rodapé de página 11 de Fundamentos Teóricos.
} 
1) Steve ii tombe en amour avec. (Steve él se enamora).

2) La boucane elle sortait du plancher. (El humo el salía de la planta).

3) Ton frèrelà, quand qu'ii va rentrer. (Tu hermano, cuándo él volverá).

4) Un home (1)a dit à l'homme... (Un hombre él dijo a um hombre...).

5) Mes parents (ils étaient partis. (Mis padres ellos partieron).

6) En Ontario les gens iShésitent. (En Ontario las pessoas ellos dudan).

7) Un Francais de France (il) va arriver au Canada ... (Un francês de Francia él llegará a Canadá).

8) Un groupe de personnes essaie de tuer um inspecteur. (Un grupo de pessoas él trata de matar a um inspector).

9) Ce gars i1 a laché l'école. (El chico él dejó la escuela).

10) petite fille pleurait. (La niña ella lloraba).

11) gars i1 tombe en bas. (El tipo él se cae). 


\section{4- A extraposição em árabe}

O árabe é uma língua semita como o hebraico e os dois idiomas têm em comum muitos fenômenos linguísticos, entre estes a possibilidade de extrapor orações ${ }^{141}$. Por exemplo:

$$
1 \text { - م بضرب محمدٌ زيدأ }
$$

Muhammad le pega a Zaid

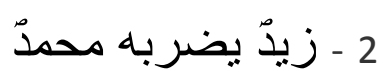

Zaid, Muhammad le pega

Nas duas orações fala-se de uma ação de "vencer" de Muhammad sobre Zaid, ainda que na oração 1 isto se presenta como uma unidade completa de informação nova, زيد a oferecida por parte do falante ao interlocutor. Na oração 2, o falante presenta como a pessoa de que se está falando e a يضربه محمد como a nova informação em relação a Zaid. زيد é apresentado como o elemento "dado" ou conhecido; o falante supõe que زي é parte da informação em comum que tem com o interlocutor (o topic), e que, encabeçando sua oração com زيد o interlocutor sabe a quem se está referindo. يضربه محمدٌ, em troca, é apresentado como algo "Novo", a nova informação que o falante tem interesse de apresentar ao interlocutor (o comment) ${ }^{142}$. A oração 2 se cria por uma reacomodação da oração 1 , assim como sua formação em hebraico. Como o falante se interessa em formar uma oração na qual Zaid seja apresentado como o personagem do qual se fala, este toma a زيدأ de seu lugar de origem (como está na oração 1) e o extrapõe no princípio da oração. Então زيد passará a ser o elemento extraposto recebendo, no caso do árabe, o caso ${ }^{143}$. O restante será a oração formal.

\footnotetext{
${ }^{141}$ Ver Peled, pág. 26.

${ }^{142}$ Ver Peled, pág. 27.

${ }^{143}$ Este é o caso 1, chamado rạ em árabe (רֵפְּ) e corresponde ao caso nominativo, que marca o sujeito ou o predicado da oração.
} 


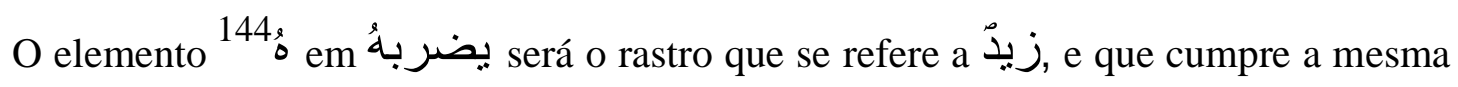
função sintática que cumpre زيداً na oração 1, isto é, de objeto direto.

Uma oração formada segundo o modelo da oração 2, isto é, uma oração extraposta é chamada em árabe de משפט ייחוד ou em hebraico. Analisando a extraposição em árabe, assim como o fiz em francês e hebraico, temos uma parte extraposta e uma parte formal, que pode ser qualquer tipo de oração de estrutura tradicional. Esta oração formal contém o rastro da parte extraposta. Quando a parte extraposta e o sujeito da oração formal marcam diferentes referentes, a parte extraposta será representada por um pronome ligado ao objeto direto ${ }^{145}$. Mas, no caso em que a parte extraposta e o sujeito da oração formal marcam o mesmo referente, o rastro aparecerá ligado ao corpo do verbo. Por exemplo:

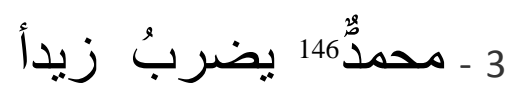

Muhammad golpea a Zaid

Não se gera a oração 3 pela permuta da ordem das palavras da oração 1, mas ela é a consequência de transferir محمد de sujeito da oração formal a elemento extraposto.

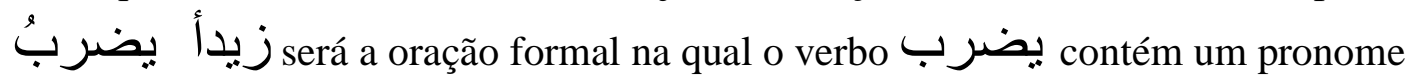
pessoal ligado, que faz referência a محمد.

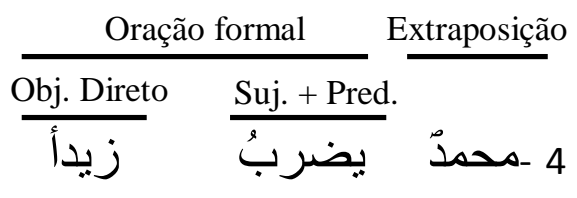

\footnotetext{
${ }^{144}$ Ver Beker, pág. 39 (substantivos não articulados).

${ }^{145}$ No caso do hebraico, o objeto direto estará representado pela preposição $E t$ (את) e sua declinação é feita segundo a pessoa a que se refere. Neste caso seria o correspondente à terceira pessoa do singular Então teríamos Oto (אותו). No caso do árabe este pronome, que se refere ao elemento extraposto, está ligado ao objeto direto.

${ }^{146}$ É importante esclarecer que as vogais e e correspondem à mesma vogal, só que a primeira equivale a uma vogal $\mathbf{U}$ e a segunda é uma vogal $\mathbf{U}$ no caso em que o sujeito não esteja articulado.
} 


$$
\frac{\text { Extraposição }}{\text { Muhammad }} \frac{\text { Oração formal }}{\frac{\text { Suj. + Pred. Obj. Direto }}{\text { golpea }}}
$$

Se observarmos as orações 1, 2 e 3, perceberemos que elas contêm a mesma informação em termos de valor semântico. O falante escolherá a estrutura para formular a oração, de acordo com o contexto ${ }^{147}$.

\subsection{Oracões extrapostas que comecam com أمََّ - em quanto a...}

As orações que começam com em quanto a têm um alto grau de extraposição, só que as mudanças morfológicas são mais variadas que em hebraico. Podemos dizer, então, que, nas orações cujas partes extrapostas são encabeçadas por أَّاَّ (em quanto a...) e o verbo da oração formal começa com ف (letra f), estamos na presença de uma extraposição de sujeito. Neste caso estamos falando de orações extrapostas enfrentadas $^{148}$ : O sujeito se confronta geralmente com uma proposição substantiva previamente mencionada, como se pode ver no seguinte exemplo:

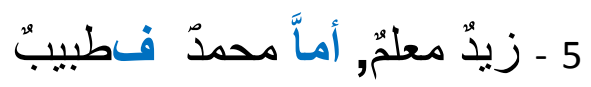

Zaid es maestro; en cuanto a Muhammad, él es médico

Na oração 5 podemos ver que محمدٌ (Muhammad) está confrontado com زيٌّ (Zaid),

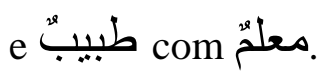

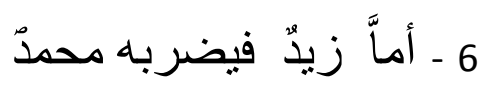

En cuanto a Zaid, Muhammad lo golpea.

147 Quero esclarecer que a ordem dos componentes da oração árabe, por omissão, é predicado+ sujeito, e isto a diferencia do hebraico, já que a ordem em hebraico é sujeito+ predicado.

${ }^{148}$ Ver Badawi, pág. 325. 
Às vezes entre أماَّ e ف podem aparecer diferentes construções como subordinadas ou coordenadas. Apesar disto, a análise sintática será sempre a mesma: tudo o que está entre ف ف ف será sempre a extraposição e tudo o que aparece depois de ف será a oração formal.

\subsection{Extraposição sujeito}

Como vimos no item Classificação da extraposição "sujeito" do capítulo sobre sintaxe bíblica, um dos tipos de oração mais comum é aquela em que existe uma cópula. Neste item foi explicado que as orações com verbos de ligação são analisadas como extrapostas segundo Driver. Não vou voltar a explicar este tema, mas sim é necessário mostrar uma análise deste tipo de oração, para marcar as diferenças entre a estrutura copulativa em hebraico e em árabe ${ }^{149}$.

A cópula nas línguas semitas é geralmente um pronome pessoal que aparece entre o sujeito e o predicado: em hebraico é chamado de אוגד e em árabe, ضَصِّر الفَصْلْ. Para analisar o uso da cópula em árabe, é necessário diferenciar três tipos de orações, que exemplificarei pelos seguintes exemplos:

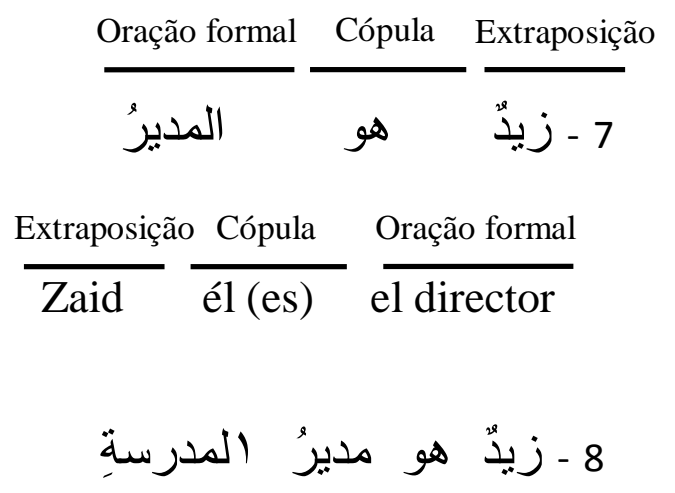

Zaid él (es) director de la escuela

${ }^{149}$ Ver Peled, pág. 29. 


\section{9}

Zaid (es) maestro

Nas orações do tipo 8, como já foi mencionado, o sujeito está geralmente articulado. O uso da cópula nestas orações está relacionado com a articulação do predicado. Nos tipos de orações como a 7, quando o predicado está articulado com ال , quase sempre haverá uma cópula, já que esta marca o vínculo predicativo entre زيدة y زيد المدرسة. Se

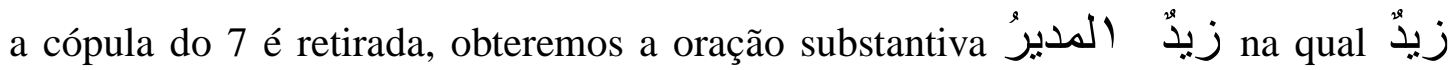
cumpre a função de núcleo, e المدير o complementa como uma aposição. Similarmente, na oração هذا هو المدير a cópula é a que estabelece a relação Sujeitopredicado entre هذا e المدير e هذا لمدير se entenderá como uma frase substantiva cujo núcleo لمدير funcionará como seu modificador direto.

As orações 7 e 8 são orações de identidade igualitária ${ }^{150}$, isto é, o sujeito e o

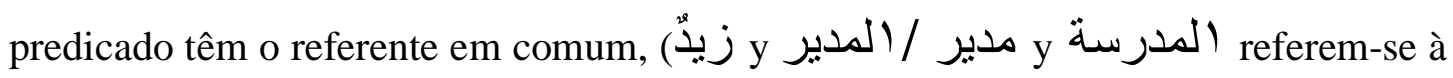
mesma pessoa na realidade). Nestes tipos de orações, nas quais o sujeito e o predicado estão articulados, podem os elementos, localizados ao lado da cópula, realizar uma permuta, sem que se afete o valor semântico da oração ${ }^{151}$. Por exemplo:

$$
10 \text { ـالمدير هو زيد }
$$

El director él (es) Zaid

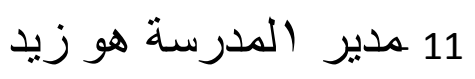

El director de la escuela él (es) Zaid

${ }^{150}$ Terminologia antes explicada no capítulo "Fundamentos teóricos".

${ }^{151}$ Ver Peled, pág. 29. 
As orações 10 e 11 são similares às 7 e 8 . Tem-se a impressão de que não é fácil estabelecer qual componente é o sujeito e qual é o predicado. No que refere ao árabe escrito, podemos dizer que, geralmente, o membro localizado à direita da cópula será o sujeito, e o da esquerda, o predicado. Isto ocorrerá sempre que a oração esteja encabeçada pela informação de que se está falando (como na oração 7). Somente nos casos em que se deduz, pelo contexto, que o membro que está à direita da cópula é a nova informação na oração, este se analisará como o predicado.

Até aqui, os casos de cópula que citei são muito parecidos aos anteriormente analisados em hebraico. Nos casos como da oração 9, quando a oração formal não está articulada, principalmente quando esta parte está composta de uma só palavra, em árabe não aparecerá a cópula ${ }^{152}$. Este é o caso que se diferencia do hebraico, já que neste tipo de oração, em hebraico, a cópula é uma opção; em árabe não o é.

Aqui, alguns exemplos de extraposição em árabe ${ }^{153}$ :

1- $\quad$ Eu como uma maçã

'anā 'ākulu tuffā $\neg$ atan.

أنا أكلت تقاحة

2- Uma maçã, ele a come

Tufāhatun, akalaha

تقاحة، اكلها

3- Ela compra flores para ele

Hiya taftari wurýdan lahu.

هي تشنزي وروداً له

\footnotetext{
${ }^{152}$ Ver Peled, pág. 29.

${ }^{153}$ Estas orações foram escritas em português por mim e a tradução foi feita pela Professora Doutora Safa Jubran.
} 
4- Ela lhe compra flores

Hiya taftari lahu wurudan

هي تشتري له ورودا

5- $\quad$ Minha mãe adora essa fruta, a manga.

'Ummi tacbadu háða alfākiha, al manga

أمي تعبد هذه الفاكهة، المانغا

6- Pagar, eu pago no banco.

Addafc, ana adfacu fi albank

الدفع، انا أدفع بالبنك

7- Daniel joga futebol

Daniel yalcabu kurata alqadam

دانيال يلعب كرة القدم

8- Daniel, ele joga futebol

Danial, huwa yalcabu kurat alqadam

دانيال، هو يلعب كرة القدم 


\section{5- O árabe e o hebraico}

Por serem o hebraico e o árabe duas línguas semitas, quase irmãs, não é difícil encontrar semelhanças entre elas. Pela história podemos ver como uma língua influenciou a outra. Por exemplo, em árabe حكيم) (חכים shaknifica médico. A partir disto podemos entender o que a Mishná nos diz na Ordem de Rosh Hashana, 2, 5: "Hachochma habaá leyeled"

seria "a parteira que traz a criança". Chamam a parteira assim por ocupar-se de um assunto médico, quer dizer, não qualquer um pode ocupar-se deste tipo de tarefa, somente os capazes, os inteligentes. Justamente a raiz da palavra inteligente surge deste termo proveniente do árabe- Chacham ${ }^{154}$.

Em árabe شهر significa mês (shahar) e, então, entendemos a origem da palavra סהر (sahar) em hebraico que significa lua, sem nos esquecermos de que o calendário hebraico se rege pela lua.

Em função do ressurgimento do hebraico, os estudiosos utilizaram as fontes sagradas para denominar os objetos, situações e noções que ainda não tinham nome na língua, e assim preencher o léxico. Contudo, em diversas ocasiões não se contava com termos úteis, pelo que se recorreu ao árabe, por ser uma língua semita, e por tanto aparentada com o hebraico. Não se havia deixado de falar o árabe ao longo dos séculos e, consequentemente, ele dispunha de vocábulos para todos os sentidos que se queria denominar. Por exemplo, para um telegrama não existia uma palavra, então se tomou do árabe barkia- برقية, não só por seu significado, senão também por ter a mesma raiz que a palavra hebraica barak- ברק, que significa raio ${ }^{155}$.

\footnotetext{
${ }^{154}$ Ver Dana, primeiro parágrafo.

${ }^{155}$ Ver Dana, sétimo parágrafo.
} 
As seguintes palavras, entre centenas delas, entraram do árabe diretamente para o hebraico:

Nadir (estranho) نادر

Rishmi o Rasmi (oficial)

تاريخ Taarich (data)

Merkaz (centro) ${ }^{157}$

أفق

O árabe penetrou no hebraico no terreno lexical e na sintaxe. Para mostrar exemplos disso é importante citar a pesquisa realizada por Nimrod Shtil sobre os trabalhos de alunos árabes no último ano de colégio; ele explica que no árabe chamado literário não há tempo presente (no falado há um presente pontual), e a forma do futuro funciona como o presente. É por isso que, às vezes, os falantes do árabe utilizam, no hebraico, a forma futura para expressar o presente ${ }^{158}$. Por exemplo:

- יגדישו את רוב הזמן בצפייה בטלוויזיה (= הם מקדישים את רוב הזמן לצפייה בטלוויזיה).

- Dedicarán la mayor parte del tiempo en ver televisión (= ellos dedican la mayor parte del tiempo en ver televisión).

- האנטרנט מלמד אותנו הרבה דברים חשובים שלא נדע אותם (=האנטרנט מלמד אותנו הרבה דברים חשובים שלא יודעים אותם).

\footnotetext{
${ }^{156}$ Ver Beker, pág. 189.

${ }^{157}$ Ver Beker, pág. 184.

${ }^{158}$ Ver Shtil, pág. 78.
} 
- La Internet nos enseña muchas cosas importante que no sabremos (=La Internet nos enseña muchas cosas importantes que no sabemos)

Alguns falantes, conscientes deste fenômeno, tratam de corrigir-se gerando outros tipos de problemas sintáticos, como uma oração com dois sujeitos ou uma extraposição, como no seguinte exemplo:

- - הלשון הנקייה היא באה למנוע פגיעה...

- El línguaje limpio él viene a evitar golpes...

O esforço para evitar o uso do futuro para falar do presente, neste caso a forma vendrá (virá) (תבוא), obriga o autor desta frase a colocar él viene (ela vem) (היא באה) depois do sujeito.

\section{$\underline{5.1 \text { As orações verbais }}$}

Outra dificuldade que podemos encontrar entre os falantes do árabe falando hebraico é em relação às orações verbais, já que, como mencionei antes, a ordem por omissão é de verbo- substantivo ${ }^{159}$. Por exemplo:

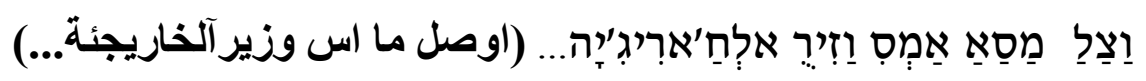

Literalmente: Chegou ontem à noite o Ministro do Exterior. Em hebraico, a ordem padrão dos componentes é de sujeito- verbo- complemento: $O$ Ministro do Exterior chegou ontem à noite.

Nas orações do tipo possessivas, o falante do árabe coloca, para encabeçar a oração, o que "possui", isto é o dono e logo depois o verbo de posse, criando assim um tipo de oração extraposta, já que despois do verbo aparece a necessidade de recordar o dono outra vez.

${ }^{159}$ Ver Shtil, pág. 80. 
1 - כל בן אדם יש לו טביעת אצבעות שונה על השני

1- Todo hombre tem él huellas dactilares diferentes del outro.

2 - רוב המדינות בעולם יש להם צנזורה על הצגות קולנוע ותיאטרון.

2- La mayoría de los paises del mundo tienen ellos censura en el cine y en el teatro

3 - אישה לומדת אין לה זמן מספיק לטפל בילדים.

3- Una mujer que estudia no tem ella tiempo suficiente de ocuparse de sus hijos.

4 - יש תלמידים שהם יש להם הפרעות קשב וריכוז.

4- Hay alumnos que ellos tienen (con ellos mismos) problemas de concentración.

\section{Situação dos magrebinos e o hebraico}

Como mencionei antes, quando uma pessoa aprende uma nova língua, esta será falada com influências da língua materna. No meu caso, por exemplo, que sou argentino, mas vivi em Israel muitos anos, nunca adquiri o sotaque israelense e, embora, com os anos, o aprimorasse, minha língua materna sempre se impôs à nova língua. Com os judeus magrebinos recém-chegados a Israel ocorria o mesmo: o francês ou o árabe se sobressaía ao hebraico. Não somente isso: usavam a terminologia árabe, quando esta não existia no hebraico e algumas destas palavras penetraram no hebraico moderno. Citarei vários exemplos da penetração do árabe magrebino no hebraico. 


\section{Marroquino faca- (מָרוֹקָאִי-סַכין)}

É um termo racista para os judeus do Marrocos, vinculando-os à violência. Segundo o sociólogo S. Eizenshtadt ${ }^{160}$, o apelativo começou a ser usado em Israel entre os anos 50 e 60, quando estes judeus chegaram a Israel e tem origem na tradição marroquina de espantar os demônios deixando uma faca com sal embaixo da almofada. Roni Somek $^{161}$ escreveu em sua poesia "Shir Patrioti” (canção patriótica):

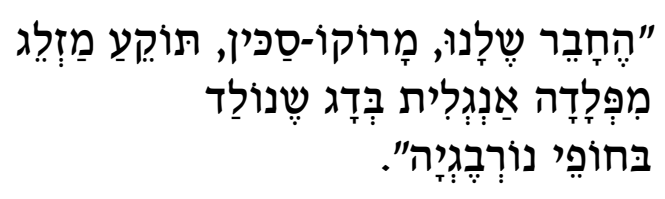

"Nosso amigo, Marrocos-faca, enfia um garfo

de aço inglês em um peixe que nasceu

nas costas da Noruega".

\section{Masuda miSderot- (מסָעוֹדָה מִשְָׁרוּת)}

Personagem estereotipado do judeu magrebino, caracterizado pelo baixo nível cultural e vivendo na periferia. Esta expressão foi criada pelo jornalista Alex Guiladi em uma entrevista para o jornal Hatikshoret, 1993 ${ }^{162}$ : "Eu faço televisão para Masuda de Sderot, e também para Moshé Ravinovich de Yavnel".

"אני עושה טלוויזיה בשביל מסעודה משדרות, וגם בשביל משה רבינוביץ מיבנאל".

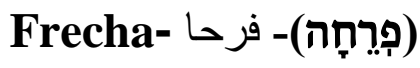

No Magreb costumava-se chamar assim as mulheres jovens. O significado desta palavra seria alegria. Em hebraico, adotou-se este termo para denominar uma jovem vulgar. É interessante observar como uma palavra de conotação positiva passou a ser negativa, deduzindo-se que o único motivo é a origem deste termo.

\footnotetext{
${ }^{160}$ Ver Eizenshtadt, pág. 322.

${ }^{161}$ Ver Somek, pág. 7.

${ }^{162}$ Ver Rozental, pág. 68.
} 


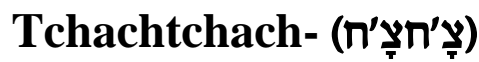

Apelido que zomba dos judeus marroquinos pela imitação fonética do árabe magrebino. Nas eleições de 1981 esta palavra transformou em um produto político que, de algum modo, conduziu Menachem Beguin ao triunfo.

\section{Kapara -}

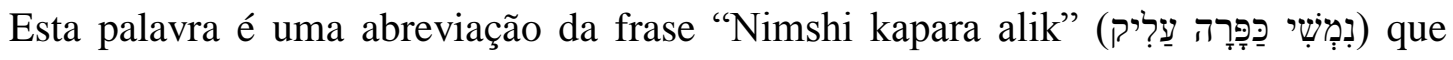
significaria: estou disposta a morrer por ti (de tanto amor), i.e., colocar-me-ia em teu lugar e expiaria por ti teus pecados.

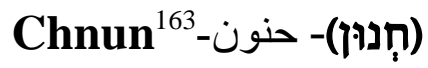

Refere-se à pessoa inteligente, mas cujos interesses não vão ao encontro dos interesses das pessoas que a rodeiam. Seria o equivalente com a palavra inglesa "nerd". O uso em hebraico é, geralmente, negativo.

\section{Lehabriz - (להבריז)- (לرز)}

Este verbo usado em hebraico provém do verbo marroquino "brez", que significa escapar. Em árabe, usa-se para dizer “isso escapou de suas mãos”. En hebraico é faltar a algum lugar ou faltar uma pessoa.

\section{Chanaj- شهناز}

O significado desta palavra é imundo, com mau cheiro.

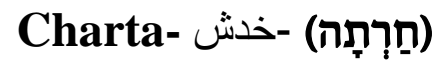

Em árabe significa arranhão e se usa quando alguém faz as coisas, mas não de forma definitiva. Arranhar algo é fazê-lo, mas não até o fỉm, não de forma definida. Em hebraico o uso desta palavra se refere a algo indefinido, sem sentido.

${ }^{163}$ Ver http://www.nrg.co.il/online/1/ART1/021/031.html 


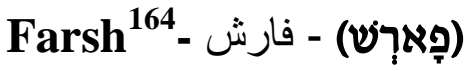

Uma coisa sem valor, miserável. Literalmente farsh é o tabaco que se mistura à droga para fazer um cigarro.

Como se pode perceber, as palavras que penetraram no hebraico moderno pelo árabe magrebino, têm, quase todas, conotação negativa. Obviamente, isto não é casual, entretanto, mais tarde, ocupar-me-ei de explicar o porquê.

Mas, não só as palavras ou frases entraram no hebraico, também podemos ver esta influência na sintaxe. Já mencionei, no capítulo de fundamentos teóricos, item 2.1, vários exemplos do livro A Caixa Negra, onde Boaz, um adolescente semianalfabeto e o marroquino, Mishel Somo, atual marido da protagonista, utilizam orações sem preposição. Este tipo de estrutura é muito fácil de ouvir entre os judeus provenientes do Magreb. Não esperava que fosse característica de semianalfabetos, mas esta associação não pode ser deixada de lado.

Los estudios sagrados, yo en general no estoy interesado. (Oz, Kufsá Schorá, Pág. 100).

- הלימודי קודש אני בכלל לא מעוניין.

Aproximadamente sesenta por ciento de lo que escribiste estoy de acuerdo. - בארך שישים אחוז ממה שכתבתה אני די מסכים.

A falta de preposição é evidente. Na primeira oração falta $\mathrm{em}$ e na segunda com.

Também no livro Shum gamadim lo Yavohu podemos encontrar este tipo de orações. Simona por exemplo, na página 21, diz o seguinte:

La semana pasada pensé que...

שבוע שעבר חשבתי ש...

Aqui faltaria a preposição em no início da oração.

${ }^{164}$ Ver Rozental, pág. 71. 
Outra característica da sintaxe utilizada pelos personagens do libro é o uso de um verbo auxiliar no passado + o verbo no presente, como haya osé, haya omer e isto pode dever-se à influência do tempo imparfait do francês ${ }^{165}$. Por exemplo, Simona, na página 12, diz:

"Solía verme dentro de los ojos de las pessoas en todo lugar que solía ir y no podía entender lo que sus ojos intentaban decirme".

"הייתי רואה את עצמי בתוך העיניים של האנשים בכל מקום שהייתי באה ולא הייתי מבינה מה העיניים שלהם מדברים אלי".

\section{Deslegitimacão da língua utilizada pelos magrebinos}

Havendo chegado a este ponto da pesquisa, é necessário reorganizar os seguintes conceitos:

1- O árabe e o francês são dois idiomas nos quais a extraposição é muito usada.

2- Os judeus provenientes do Magreb falavam árabe e/ou francês.

3- Muitas palavras, frases ou estruturas linguísticas em árabe ou francês penetraram no hebraico de forma inconsciente pelo judeu do Magreb.

4- Todas as penetrações linguísticas, provenientes dos judeus do Magreb, têm conotações negativas ou são consideras parte de um registro baixo da língua (incluindo, neste caso, a extraposição).

Chegando a esse ponto, é fundamental esboçar algumas hipóteses de cunho sociohistórico para compreender o processo de deslegitimação da língua utilizada pelos mizrachim ${ }^{166}$, em especial, aqueles provenientes do Magreb, principalmente naquilo que foi o objetivo desta tese de doutorado: a extraposição. Vimos, no decorrer desta pesquisa, as diferentes fases e formas em que esta estrutura se desenvolveu ao longo dos séculos, além de ter demonstrado que a extraposição é um fenômeno que forma parte da gramática do hebraico sendo utilizada nos textos

\footnotetext{
${ }^{165}$ Ver Rozental, pág. 69.

${ }^{166}$ Este termo, gerado na sociedade israelense, se refere aos judeus provenientes dos países árabes ou islâmicos.
} 
canônicos do judaísmo, principalmente na bíblia hebraica, que constitui o padrão da língua hebraica para definir o que não lhe pertence do ponto de vista linguístico.

Como fora esboçado muito brevemente na Introdução deste trabalho, o projeto sionista, incluindo o renascimento da língua hebraica como língua moderna e falada, foi um empreendimento dos judeus ashkenazitas, i.e., dos judeus europeus. O ideal sionista do "retorno dos exílios" e da "reunião dos exílios ${ }^{167, ", ~ e n t r e t a n t o, ~ n a ̃ o ~ f o i ~ u m a ~}$ política pacífica e isenta de conflitos. Assim, o novo judeu, o sabra, deveria ser a antítese do judeu diaspórico, este último ligado à tradição judaica religiosa, confinado em bairros ou guetos judaicos, perseguido, dedicado ao estudo ou a atividades comerciais, emfim, longe da terra, do trabalho da terra e incapaz de defender-se de ataques antissemitas. Os componentes socialistas e cooperativistas da ideologia sionista em seus primórdios também estiveram permeados pela europeia visão de mundo da época. Mas, quando o Estado de Israel foi proclamado em 1948, grande parte dos imigrantes que chegaram entre 1948 e 1952 eram provenientes dos países árabes e muçulmanos. Mais precisamente, entre os 600.000 imigrantes que o novo Estado recebeu nesse período, a metade era composta por sobreviventes da Segunda Guerra e a outra metade, por judeus do Magreb, da África do Norte, de diferentes regiões da Ásia, os chamados mizrachim ou orientais, com o passar dos anos, conhecidos em Israel como os bnei edot ha'mizrach: os filhos das comunidades orientais.

Evidentemente, tal classificação ${ }^{168}$ não respondeu a um critério geográfico. Ela teve como objetivo principal inserir em uma categoria todos os novos imigrantes não europeus. É interessante assinalar, como o faz Topel em seu trabalho ${ }^{169}$, que tal categoria é um tanto curiosa uma vez que não existe a oposta, i.e., os bnei edot ha'shkenaz.

Como Rozenchan ${ }^{170}$ descreve muito claramente, ao chegarem ao país, os marroquinos viveram por dois meses em acampamentos de imigrantes; a seguir foram

\footnotetext{
${ }^{167}$ Esta frase bíblica se refere a que o povo judeu se juntará novamente na Terra de Israel.

168 Ver Topel M. cap. 3.

169 Ver Topel M. cap. 4.

${ }^{170}$ Ver Rozenchan, pág. 20.
} 
levados às maabarot, moradias rústicas (tendas e barracões de lata) que, apesar da previsão de serem utilizadas por um breve período, perduraram por muito tempo.

O tema da conflituosa adaptação dos judeus orientais à sociedade israelense secular e moderna foi alvo de numerosas pesquisas, cunhando-se a expressão kipuach bnei edot hámizrach: a discriminação das comunidades orientais ${ }^{171}$. Acredito ser interessante salientar que parecia não existir em pesquisas sobre a dimensão linguística do processo de discriminação mencionado e que, de algum modo, foi a conclusão desta tese em relação á extraposição. Rozental ${ }^{172}$ comenta em seu artigo não haver encontrado um estudo linguístico profundo sobre este assunto, supondo que uma pesquisa deste tipo poderia "sensibilizar" grande parte da sociedade israelense.

Como mencionei, com o objetivo de aprofundar o fenômeno de extraposição a partir de uma abordagem sociohistórica, é necessário levar em consideração que a discriminação, preconceitos e controle cultural das populações chamadas orientais têm raízes profundas. Assim, em seu clássico Orientalismo, Said ${ }^{173}$ afirma que os estereótipos atribuídos às culturas orientais e aos indivíduos tidos como orientais são muito específicos: os orientais são despóticos quando estão em situações de poder e facciosos e subservientes quando ocupam posições subalternas. Os orientais são capazes de abstrações sofisticadas, mas incapazes de organizar-se de forma prática. Seus homens são lascivos enquanto suas mulheres só se veem atrás de grades. Por definição, os orientais são estranhos. Há um processo de fazer do outro uma entidade exótica. Na mesma obra, Said argumenta que o oriental é um mito produzido pelo pensamento europeu a partir do século XVIII. De algum modo, seu livro é uma tentativa de desmantelar esse mito, além do mais, identificar as características do Orientalismo como um tipo de discurso.

Assim, Said afirma que os europeus dividiram o mundo em duas partes: leste e oeste, oriente e ocidente, civilizados e não civilizados. Segundo ele, esta é uma divisão totalmente artificial construída sobre a base da dicotomia "nós" e "eles". Por outro lado, estas categorizações ajudaram os europeus a definirem-se a si mesmos: os atributos associados aos orientais eram aqueles cujos opostos caracterizavam os

\footnotetext{
${ }^{171}$ Ver Kimerling B. parte 2, cap. 6. Ver Smooha S. cap. 172- 202.

172 Ver Rozental, pág. 96.

${ }^{173}$ Ver Said, pág. 293.
} 
ocidentais. Essa foi uma estratégia para justificar a colonização da Ásia e da África. Sua crítica é que os orientalistas fizeram generalizações com objetivos políticos de dominação, não incluíram em suas pesquisas a voz dos orientais e, finalmente, criaram uma fronteira absolutamente artificial entre Oriente e Ocidente.

Para compreender a aliá da década de 1950 em Israel, identificada principalmente com a dificuldade de absorver os imigrantes orientais, é importante definir o que estava em jogo nessas primeiras décadas da existência do Estado de Israel, e quais foram as regras pré-estabelecidas para que o projeto sionista se concretizasse.

Na dimensão estrutural, devemos destacar oito problemáticas, tanto políticas, como sociais, econômicas e demográficas. Assim:

1) Até a guerra de 1967, a própria existência do Estado de Israel estava em jogo como consequência das guerras desencadeadas pelos países vizinhos;

2) Necessidade de desenvolver uma economia estatal, sob o ideal dos chalutzim ${ }^{174}$;

3) Economia precária;

4) Povoamento das terras concedidas com a Partição da Palestina;

5) Criação e desenvolvimento de instituições políticas, judiciais, educativas, etc.;

6) Absorção dos olim ${ }^{175}$;

7) Organização do exército;

8) Altos índices de desemprego.

Na dimensão ideológica, o grande desafio para as elites (culturais e políticas) era consolidar uma identidade coletiva que superasse as identidades particularistas

\footnotetext{
${ }^{174}$ Chalutzim eram chamados àqueles judeus que chegaram à Palestina com o objetivo de levantar uma nova nação e dispostos a qualquer tarefa para alcançar este fim.

${ }^{175}$ Este termo, olim, vem do verbo laalot que significa subir. Foi definido segundo as Fontes judaicas e a lei israelense. Segundo as fontes, quando um judeu chegava em Israel, se dizia que subia à Israel, fazendo referência a uma elevação espiritual. Em termos legais, será um Ole aquela pessoa judia que decide estabelecer-se em Israel.
} 
dos olim, principalmente dos imigrantes orientais. Essa nova identidade deveria articular-se ao redor de uma relação especial dos judeus com seu passado e seu futuro, que nesse momento se opunha à visão religiosa da vida judaica transcorrida durante séculos na diáspora. A nova identidade se expressou na lealdade dos judeus ao Estado de Israel, às premissas sionistas, assim como elas eram concebidas pelas elites. O renascimento da língua hebraica e seu estabelecimento como língua oficial do Estado foram fundamentais para a concretização da nova identidade israelense.

Para alcançar esse objetivo, construiu-se uma narrativa que, em pouco tempo, foi ubíqua e deslegitimou qualquer intento de ver, compreender e agir de forma alternativa. Nesse sentido, a narrativa sionista prescreveu os limites do discurso e das práticas não discursivas. Porém, não se deve homologar a sociedade israelense aos regimes totalitários, uma vez que estamos falando de um regime democrático ${ }^{176}$. $\mathrm{O}$ ponto para se entender o poder do Sionismo e do discurso sionista é a legitimidade imanente a ele. Se uma história pós-sionista dos acontecimentos dessa época trata de dar ênfase aos conflitos, a narrativa sionista os minimizou ou negou sua existência. É importante lembrar que, na academia israelense, alguns pesquisadores desenvolveram pesquisas que tentaram demonstrar o primitivismo dos imigrantes orientais ${ }^{177}$. O poder da narrativa sionista foi a construção de um consenso nacional, por meio de diferentes práticas discursivas e não discursivas.

Segundo Yaron Ezrahi o sionismo é uma narrativa épica, na qual não há lugar para o indivíduo e narrativas alternativas. Como movimento, o Sionismo inspirou-se mais no nacionalismo e diversas variantes coletivistas do socialismo do que no liberalismo democrático individualista. Nessa concepção, qualquer indício de individualismo era considerado fraqueza, egoísmo, depravação moral e materialismo. O pioneiro, encarnado na figura do kibutznik foi o ideal mais prezado. E apesar de o kibutz não representar mais do que 5\% da população, o enaltecimento do papel do kibutznik foi projetar ideais de altruísmo, camaradagem, sacrifício em prol do todo, patriotismo e

\footnotetext{
${ }^{176}$ Ver Yaron Ezrahi, 1996.

${ }^{177}$ Ver Topel M. cap. 4.
} 
alta moral em relação ao trabalho. Estes ideais eram compartilhados pela maioria dos setores da sociedade israelense que os consideravam fundamentais para a existência do Estado. Entretanto, ideais e valores cooperativistas, seculares, socialistas e modernos não faziam parte do repertório cultural dos imigrantes orientais que chegaram a Israel com outros ideais, basicamente, conseguir ser melhores judeus na Terra de Israel, dando continuidade às tradições que trouxeram de seus países de origem.

As organizações que veiculavam esses ideais na população eram: o exército que, nas primeiras décadas do Estado, teve funções chave na sociedade civil; ulpanim para olim; escolas públicas; movimentos juvenis e meios de comunicação.

Nesse discurso, os conceitos chaves para compreender a realidade e para atuar sobre a realidade tinham como base a dicotomia exílio-moledet (pátria), com suas conotações negativas e positivas.

A hegemonia do discurso sionista sofreu as primeiras rupturas nos cenários social, cultural e político a partir das Guerras de 1967, Yom Kipur 1973 e 1982. A primeira intifada, com certeza, marcou o fim desse consenso nacional construído desde a chegada dos primeiros pioneiros no final do século XIX, início do século XX.

Kimmerling aponta ${ }^{178}$ o movimento dos Panteras Negras como uma das primeiras vozes que entraram em conflito direto com o consenso nacional. Assim, na Guerra de Yom Kipur, pela primeira vez, os mizrachim participaram num conflito bélico, selando o "pacto de sangue", necessário para serem considerados verdadeiros e leais cidadãos do Estado $^{179}$. O alto número de soldados mizrachim que participaram dessa guerra fez pensar que a adaptação deles à sociedade israelense tinha sido alcançada. Porém, os distúrbios violentos em Wadi Salib (Haifa) na década de 1950 e em Jerusalém em 1971 tiveram a função de mostrar aos israelenses que a questão étnica não havia sido resolvida. Os Panteras Negras, provenientes da periferia de Jerusalém, organizaram manifestações na cidade contestando pela primeira vez publicamente o “kipuach edot ha'mizrach", reivindicando:

178 Ver Kimmerling, parte 2, cap. 6.

${ }^{179}$ Ver Cohen, 148. 
Acabar com a discriminação;

Elevar o nível de vida dos orientais;

Ajudar os filhos dos orientais a conseguir uma inserção igualitária no sistema;

Incorporar a cultura oriental à cultura israelense.

Erik Cohen ${ }^{180}$ assinala que, depois de décadas de ameaça à existência do Estado e de precária situação econômica, a década de 1970 se revelou como o momento para que os orientais expressassem suas reivindicações. A sociedade israelense da os primeiros passos para refletir sobre os conflitos internos.

Nessa época, mais do que na atualidade, as instituições pilares eram dirigidas por ashkenazitas: o executivo e o legislativo, partidos políticos, sindicatos, as maiores empresas, universidades, escolas públicas e atividades culturais. Paralelamente, a brecha socioeconômica entre ashkenazim e sefaradim continuava sendo grande, sem nenhum indício de se desenvolverem tendências opostas. A cultura oriental só era respeitada quando concebida como traços folclóricos: música, culinária, vestimenta.

Pressionados a se ocidentalizarem, os mizrachim não tinham conseguido chegar ao status social dos ashkenazim, o que estava implícito na ideologia do kibutz galuiot. As cidades em desenvolvimento mais pobres (como a cidade na qual transcorre o romance analisado ao longo desta tese) eram povoadas por mizrachim, assim como os moshavim mais pobres e as periferias das grandes cidades. Foi na periferia de Jerusalém que surgiu o Movimento dos Panteras Negras. E é nessa época que Alex Weingrod ${ }^{181}$ falará da existência de um Primeiro e um Segundo Israel. Em relação ao movimento dos Panteras Negras, em particular, e à discriminação contra os orientais em geral, a explicação das lideranças e da sociedade israelense como um todo foi a seguinte: os orientais chegaram com uma cultura primitiva, porém, depois de se

\footnotetext{
${ }^{180}$ Ver Cohen, 170.

${ }^{181}$ Ver Weingrod, 1962
} 
ocidentalizarem na segunda geração, as brechas entre ashkenazim e orientais desapareceriam. Isto não aconteceu.

É importante destacar que o que os Panteras reivindicavam era uma plena participação dos orientais na vida israelense como orientais. Todavia, o Movimento dos Panteras Negras, embora possa ser apontado como uma das primeiras vozes que se fizeram ouvir no cenário israelense, não foi suficiente para consolidar estratégias que permitissem a reformulação do discurso sionista que incluísse a realidade sociocultural dos imigrantes dos países orientais.

Embora durante décadas a situação dos orientais não tenha ocupado um lugar central nos conflitos diversos que assolam a sociedade israelense, é importante salientar que a situação das segunda e terceira gerações, embora tenha melhorado se confrontada aos imigrantes da década de 1950, não pode equiparar-se à mobilidade ascendente pela qual passaram os imigrantes ashkenazitas. Em função dessa realidade, o fenômeno da luta contra o kipuach edot hámizrach tem adotado novas facetas e novas estratégias. Estou me referindo, basicamente, ao grande poder de convocatória do movimento SHAS, liderado pelo carismático rabino Ovadia Yosef. O movimento, que tem um braço político partidário, o partido SHAS, tem desenvolvido numerosas táticas para lutar contra a discriminação dos mizrachim. Assim, além das reivindicações no Knesset, Shas criou uma extensa rede educativa, ajuda para estudantes de academias rabínicas e apoio psicológico, espiritual e financeiro para aqueles jovens orientais que não conseguiram espaço na sociedade israelense, caindo, frequentemente, na criminalidade e nas drogas. Para esses jovens, como condição para receber ajuda, exige-se um compromisso religioso rígido ${ }^{182}$.

É necessário esclarecer que o "primitivismo" dos imigrantes orientais foi uma expressão usada abertamente em discussões públicas na década de 1950: na sociedade geral, no Parlamento e na própria Academia. Assim, por exemplo, no jornal Ha'aretz (22 de abril de 1949), o colunista Arye Gelblum escreveu o seguinte:

${ }^{182}$ Ver Lehmann e Siebzehner, caps. 4 e 5. 
Uma séria e ameaçadora questão é colocada pela imigração da África do norte. Essa é a imigração de uma raça que até agora nunca tínhamos conhecido neste país...

Nela há pessoas cujo primitivismo alcança o ponto máximo. Seu nível educacional atinge os limites da ignorância absoluta. Mais séria ainda é a incapacidade para absorver qualquer coisa que seja intelectual. Quantos obstáculos vamos ter de superar para educar esses africanos!... Quando um imigrante búlgaro discutiu com um marroquino para que respeitasse seu turno na fila do almoço, o sujeito tirou uma faca e lhe cortou o nariz...

Nos quarteirões dos africanos [preste-se atenção que Gelblum não se refere a eles como norte-africanos], nos campos transitórios nos quais eles vivem, só se encontra sujeira, jogo de cartas e apostas, fornicação e embriaguez... sem mencionar a imoralidade e os roubos que lá imperam... Em um dos campos eles tramaram uma revolta que incluía o assassinato de um dos funcionários da Agência Judaica.

O que, então, pode ser feito com eles? Como "absorvê-los"?... E a eles vão se juntar mais e mais imigrantes. Se esse processo não for realizado com cautela e gradativamente, eles vão nos "absorver", em lugar de nós os "absorvermos" 183.

Os acadêmicos (antropólogos, sociólogos, educadores e assistentes sociais), apesar de terem tentado mitigar os excessos da política da mistura dos exílios, compartilhavam com as elites políticas a premissa básica de que a "absorção" dos novos imigrantes pela sociedade israelense era necessária e positiva.

Um dos resultados da política de absorção foi enfatizar as características estruturais das comunidades orientais e os traços psicológicos dos imigrantes, sem compreender a importância da cultura como mecanismo de adaptação. Assim, os imigrantes orientais foram transformados em objeto de políticas públicas e de ideologias desenvolvidas pelas elites ashkenazitas. O fardo do processo de absorção centrou-se no indivíduo, já que as famílias e culturas dos orientais foram relegadas a

183 Ver Segev, págs. 159- 160. 
um segundo plano. Nesse processo, os imigrantes orientais tiveram as culturas neutralizadas e a interação com os membros da sociedade maior foi efêmera (dado o isolamento das comunidades às quais foram encaminhados) ficando nas periferias urbanas e rurais da sociedade israelense. Sendo esta a situação dos judeus do Magreb, é lógico pensar que o hebraico falado por eles, fosse rejeitado também. É esse o motivo pelo qual a extraposição, usada por eles, já que é um fenômeno muito presente em frances e árabe, seja considerada um fenômeno do registro baixo da língua; a extraposição se transformou em um fenômeno da língua coloquial e não é aceita pelos falantes nativos, como consequência da discriminação dos falantes do Magreb.

\section{8- Conclusão parcial e avaliações}

Neste capítulo, analisou-se, em termos linguísticos, por um lado a influência de uma língua materna na nova língua adquirida e, por outro, como penetraram o árabe e o francês, falados pelos judeus do Magreb a nova língua adquirida, o hebraico. É quase impossível evitar que um falante não "contamine" a nova língua, com a língua materna. Por isso o falante proveniente do Magreb incluiu muitas palavras e estruturas no hebraico adquirido: entre estas estruturas encontramos a extraposição, fenômeno característico do árabe e do francês.

Os sentimentos de injustiça pelas discriminações e consequentes desigualdades socioeconômicas e o isolamento em todos os níveis de vida nacional foram logo nitidamente perceptíveis entre os imigrantes do Magreb.

Houve uma ingerência intensa, forçada, em todos os âmbitos da vida dos imigrantes, desde o fato de serem direcionados a localidades de moradia em lugares específicos, geralmente em condições muito precárias, isolados dos eixos principais da vida do país, até os ramos de atividades a que foram encaminhados e interferência em hábitos pessoais.

Essa imposição, de nivelar todos os israelenses, despojando-os de suas características particulares, levou a um acúmulo de dificuldades e afetou, de algum modo, o respeito pela estrutura familiar tradicional, fortemente centralizada na figura patriarcal. A sociedade receptora, ou seja, os israelenses de origem europeia, referia-se a esses 
imigrantes, cuja cultura era considerada inferior à cultura ocidental predominante no país, como "primitivos".

A representação dos povos orientais foi importante para a própria definição da identidade ocidental na legitimação de seus interesses colonialistas.

O surgimento do movimento dos Panteras Negras expôs pela primeira vez, a imponente tensão social dentro da sociedade israelense, intentando colocar um fim ao continuo kipuach edot hamizrach.

Como disse Alex Weingrod, gerou-se a ideia de "dois Israéis", a divisão da sociedade israelense em dois campos culturais: um Israel, sinónimo das primeiras gerações de imigrantes europeus, de visões pioneiras, ambicionando posicionar-se em um bom lugar social e de abundância e o outro Israel, proveniente do Magreb, vivendo em zonas de desenvolvimento, na periferia, ansiando por postos de trabalho estáveis, aceitação social e uma vida melhor para os jovens.

Sendo os judeus do Magreb considerados uma classe pobre e depreciada, também são mal julgadas a maioria das coisas provenientes deles. $\mathrm{O}$ hebraico falado por eles é considerado inferior, primitivo e com conotações negativas sendo categorizado como parte de um registro baixo da língua, incluindo neste caso, a extraposição. Ou seja, a extraposição é muito usada em hebraico pelos judeus provenientes do Magreb, já que é um fenômeno muito comum do árabe e do francês, suas línguas maternas. Se a extraposição faz parte da gramática hebraica, já que é parte do sistema gramatical da Bíblia e do Talmud, a meu ver o único motivo para que seja ligada a com um fenômeno de registro baixo é a associação com seus falantes:

O árabe e o francês são dois idiomas onde a extraposição é muito usada. Os judeus provenientes do Magreb falavam árabe e/ou francês. Muitas palavras, frases ou estruturas linguísticas em árabe ou francês penetraram no hebraico de forma inconsciente por eles. A extraposição é considerada como parte do registro baixo do hebraico, já que seus falantes foram posicionados como primitivos e com pouca cultura. Estamos na presença de uma categorização linguística como consequência de uma discriminação dos falantes. 


\section{Conclusões}

A extraposição, em hebraico, é uma oração composta por uma estrutura basicamente substantiva. Diferenciamos nela uma parte extraposta a que podemos chamar sujeito psicológico e outra parte chamada oração formal que não está subordinada à primeira parte extraposta. Esta diferenciação se expressa pela prosódia na linguagem oral e pela pontuação na linguagem escrita. Por um lado, conhecem-se características sintáticas que diferenciam estas orações de outras, como o isolamento de um membro e sua representação na oração formal, deixando, em sua maioria, um rastro, ainda que este não seja obrigatório, e a falta de subordinação entre estas duas partes. Por outro lado, há um desgaste na ênfase da expressão de algumas estruturas que, principalmente, são orações extrapostas. A conversão de uma oração simples em uma extraposta consiste em uma troca de estrutura colocando um dos componentes da oração como sujeito psicológico. Como esta troca, de posicionar este componente como sujeito extraposto, implica uma posição substantiva, é comum que os

componentes extrapostos sejam de natureza substantiva: sujeito, objeto ou modificador direto. Também os circunstanciais e o verbo podem ser extrapostos, ainda que este movimento seja menos comum. O movimento mais comum é o do objeto e o modificador direto. O isolamento e a reiteração são características pronunciadas da extraposição, mas nem sempre a reiteração tem expressão morfológica na oração formal e, às vezes, surge do contexto. Isto faz pensar de outra maneira a ideia de extraposição, já que a condição necessária para que a extraposição exista é o isolamento. Este isolamento tem níveis, começando pelo nível mais alto que se caracteriza por conter a estrutura en cuanto a ([ב]אשר- ל-) até o isolamento, que se consegue trocando a ordem das palavras da oração. O fato de que, por um lado, há características específicas para esta estrutura e, por outro lado, há um desgaste na ênfase da extraposição não é antagônico, já que isso é uma característica em si da língua. Não se pode discutir sobre um fenômeno que ocorre em uma língua viva do ponto de vista estatístico, ainda que minha impressão seja que a extraposição dianteira é mais comum que a traseira, tanto na língua oral como na escrita; assim 
também como o substantivo extraposto em comparação com um verbo nesta posição. A distribuição das extraposições não é limitada na língua oral ou na escrita, mas, segundo meu parecer, quando o rastro não é substantivo, aparece menos do que se pode imaginar. As estruturas nas quais a ênfase foi-se perdendo não transmitem uma mensagem emocional, mas nas orações nas quais a extraposição é persistente, o sujeito psicológico será bem enfatizado e as mensagens são claramente emocionais.

Sobre o livro "Shum gamadim lo Yavohu" creio haver deixado claro, depois desta busca e análise exaustiva, que o uso característico e repetitivo de orações extrapostas intensifica a sensação de estar na presença de um hebraico de registro baixo. Por meio de uma família marroquina no livro "Shum gamadim lo Yavohu", a escritora Sará Shilo nos mostra essa linguagem pouco desenvolvida, dando essa sensação pelo repetitivo uso da extraposição. Isto quer dizer que o fenômeno de extraposição reflete um hebraico não padronizado, não aceito pela sociedade. Mas sendo a Bíblia a principal fonte do hebraico e aparecendo nela a extraposição como um fenômeno sintático recorrente, podemos afirmar que este fenômeno é parte da gramática hebraica. Seria possível trazer exemplos onde se extrapõe o sujeito, o predicado, os modificadores, os objetos e os circunstanciais. Podemos encontrar também estruturas diversas dentro deste fenômeno, o que o faz mais comum ainda, demonstrando que seu uso não contraria a regra. Por estes exemplos e análise podemos afirmar que o uso da extraposição na Bíblia forma parte do sistema gramático hebraico. Também ficou demonstrado que o Talmud apresenta vários exemplos de extraposição simples e simulada. A Bíblia e o Talmud são o padrão e a autoridade para estabelecer quais fenômenos linguísticos são parte da gramática hebraica e quais não são.

Então por que ainda é considerada como parte do registro baixo da língua?

Ao menos por quatro décadas, imigrantes do Marrocos e seus descendentes viveram principalmente em localidades e cidades da periferia e nas assim denominadas "pequenas cidades em desenvolvimento", locais que não gozaram de recursos suficientes e cujo desenvolvimento econômico lento fez com que somente aumentassem as brechas socioeconômicas entre judeus do Marrocos e os que habitavam as principais cidades do país. 
Houve uma imposição para os orientais abdicarem de símbolos e valores tradicionais que trouxeram consigo, com a intenção de que absorvessem valores e símbolos da sociedade em que passaram a viver e à qual se deveriam fundir.

Em suma, a negação da diáspora e a privação das tradições culturais dos judeus do Magreb à margem não permitiram que eles se integrassem à nova cultura de Israel e foram deixados nas margens da sociedade.

A tentativa de construir uma nova cultura, em parte, foi conseguida, mas a tentativa de construir uma cultura israelense unificada falhou.

O Oriente é uma invenção do Ocidente, algo que se tornou necessário para que os ocidentais pudessem assim afirmar sua superioridade, e se reconhecer como tal por ter um "outro" onde se apoiar e se sobressaír como superiores.

Surgem os "Panteras Negras", um movimento criado em Israel nos anos 70, reivindicando-se como defensores dos israelitas originários do Médio Oriente, em face do domínio social que na época era exercido pela população oriunda da Europa e dos EUA.

Fala-se da ideia de "Dois Israéis"; um deles representava o ideal ashkenazita do homem do Kibutz, o pioneiro europeu cultural e socialmente, o outro era o Israel mais novo, cuja origem se da em terras muçulmanas, da periferia.

Esta pesquisa ensina-nos que o fenômeno de extraposição, que é muito usado na língua hebraica atual, faz parte da gramática hebraica, apesar de a maioria dos falantes a considerarem um fenômeno que não pertence ao hebraico e seu uso aparece somente em um registro baixo do idioma. A extraposição é parte do sistema sintático e morfológico da língua hebraica e seu uso é espontâneo.

Este fenômeno existe na literatura bíblica e talmúdica de maneira natural como qualquer outro fenômeno linguístico e surge por uma necessidade do falante de enfatizar um componente da oração.

Este fenômeno entrou de maneira forte no hebraico moderno por influência dos falantes do árabe e do francês, que chegaram a Israel, vindos do norte do Magreb.

Posso concluir que a extraposição considerada parte do registro baixo da língua é uma forma de discriminar o falante, que intensificou o uso deste fenômeno no hebraico por influência das línguas maternas. 


\section{0- Bibliografia}

\section{I- Livros de pesquisa e crítica}

\section{Em hebraico}

ABADI, Adina. Tachbir Hasiach shel Haivrit Hachadashá (Sintaxe do discurso do Hebraico Moderno), Jerusalén: Magnes Press, 1987.

AZAR, Moshé. Kolel Umechubar Bemivne Hashetach Umivné Haomek (Integracião e conexão em estrutura superficial e estrutura profunda). In Balshanut hofshit, n. 9, Ramat Gan: Universitat Bar Ilan Press, p. 1- 16, 1974.

Mishpetei Yichud Medumim BaMishná (Orações simuladas na Mishná). In Leshonenu, n. 47, Jerusalén: Academia de la Lengua Hebrea Press, p. 264- 271, 1982.

Likrat havanat hamishpat hamemukad beivrit bat zmanenu (A compreensão da oração topicalizada no hebraico moderno). In Haivrit Safá Haiá, Haifa: Universidade de Haifá Press, p. 87- 101, 1992.

Shetach Veomek Betachbir (Estrutura superficial e profunda em sintaxe), Haifa: Universidade de Haifa Press, 1977.

Tachbir Leshón HaMishná (Sintaxe da linguagem da Mishná), Jerusalem: Academia de la Lengua Hebrea Press, 1995.

BAR, Tali. Hayichud Baivrit Bat Zmanenu (A extraposição no hebraico moderno). In Lesshonenu, n. 60, Jerusalén: Academia de la Lengua Hebrea Press, p. 297- 328, 1996. 
Mivne Tnai pashut baivrit bat zmanenu (Estrutura condicional no hebraico contemporâneo). In Balshanut Ivrit, n. 53, Ramat Gan, Bar Ilan University Press, p. 29$41,2003$.

BEKER, Dan. Aravit Lematchilim (Árabe para principiantes), Tel Aviv: Diunon Press, 1997.

BENDAVIV, Abba. Leshón Mikrá ve Leshón Chachamim (A Língua Bíblica e a língua dos Sábios), Tel Aviv: Dvir Press, 1971.

BEN TULILA, Yaacov. Corpus Hatzarfatit Shel Montreal- Deguem Efsharí Lecheker Haivrit Hameduberet (Corpus Francês de Montreal- Exemplo possível para a pesquisa do hebraico oral). In Balshanut Ivrit, n. 27, Ramat Gan: Bar Ilan University Press, p. 1328,1988

BLANK, Hayim. Leshon Bnei Adam (Linguagem dos humanos), Jerusalén: Mosad Bialik Press, 1989.

BLAU, Yoshua. Sefer Chadash al Tachbir (Novo livro sobre sintaxe). In Leshonenu, n. 22, Jerusalén: Academia de la Lengua Hebrea Press, p. 67- 77, 1978.

BOROCHOVSKI BAR ABA, Ester. Dikduk Halashón Hameduberet (Gramática da linguagem oral). In Leshonenu, cadernos 2 e 3, Jerusalén: Academia de la Lengua Hebrea Press, p. 75- 88, 2003.

Dvarim Sheein Haniyar Sovel- Iyun Betxtim Makbilim Dvurim Uchtuvim (Questões que o papel não suporta- Análise de textos paralelos orais e escritos). In Teuda Medabrim Ivrit, n. 18, Tel Aviv: Univesidade de Tel Aviv Press, p 353- 374, 2001. 
Tofaot shel hafaká baivrit hameduberet (Fenômenos de produção en hebraico Oral). In Haivrit Veachaioteia, n. 4- 5, Haifá: Universidade Haifá Press, p. 81- 104, 2005.

BRAFMAN, Meir Moshé. Mibeaiot Hasintaxis (Dos problemas de sintaxe). In Tarbitz, n. 16, Jerusalén: Magnes Press, p. 181- 192, 2003.

DANA, Yosef. Munachim Araviim Shechadru Laivrit (Términos árabes que penetraram no hebreaico), In Bechimat 2000, n. 7, Jerusalem: Academos Press, 2002. Disponível em http://www.snunit.k12.il/heb_journals/kimat2000/007017.html

EIZENSHTADT, Shmuel. Hachevrá Haisraelit Bitmuroteia (A sociedade israelense e as mudanças), Jerusalem: Agnus Press, 1988.

FRUCHTMAN, Maya. Leshoná Shel Sifrut (A linguagem da literatura), Even Yehuda: Reches Press, 1990.

GODSHTEIN, Paul Matitiahu. Halashón Haivrit Hameduberet Kenosé Lemehkar (A língua hebraica oral como assunto de pesquisa). In Leshonenu, n. 17, Jerusalén: Academia de la Lengua Hebrea Press, p. 231- 241, 1950.

GOLDENBERG, Gideon. Al Torat Hapoal Vehapoal Veivrit (Sobre a teoria do verbo e o verbo em hebraico), In Mechkarim Belashón, n. 1, Jerusalem: La Universidad Hebrea, p. 295- 348, 1985.

GUIORA, Rachel. Seder Hamilim Bamishpat Veiachasó el hatext (A orden das palabras na oração e seu vínculo textual), In Iunim Becheker Hasiach, Jerusalem: Academón Press, p. 263- 302. 
GVURÁ, Avi. Iunei Tachbir Bachozé Hamishpatí (A anánlise sintática no Contrato Judicial). Beer Sheva: Mosad Bialik Press, 2000.

HARAMATI, Shlomo. Ivrit Safá Meduberet (Hebraico na linguagem oral). Tel Aviv: Misrad Habitachon Press, 2000.

ILANI, Noga. Hatnaiot Heksheriot Lemivne Hayichud Baivrit Hachadashá (Condições contextuais para a estrutura de extraposição no hebraico moderno). In Helkat Lashón, n. 35, Tel Aviv: Tel Aviv University Press, p. 20- 32, 2004.

KADARI, Menachem Tzví. Parshyiot Betachbir Leshon Hamikrá (Assuntos da sentaxe bíblica). Ramat Gan: Bar Ilan Press, 1976.

KIMERLING, Baruch. Mehagrim, Mitiashvim, Ielidim (Migrantes, Colonos, Nativos). Tel Aviv: Am Oved, 2004.

KUZAR, Ron. Psukiot Nominalizatzia baivrit haisraelit (Proposições nominais no hebraico israelense). In Balshanut Ivrit, n. 36, Ramat Gan: Bar Ilan University Press, p. 72- 82, 1992.

LANDAU, Beni. Psukit Hatnai Betachbir Hamishpat Uvetachbir Hatext (Subordinada de condição na sintaxe da oração e do texto). In Balshanut Ivrit, n. 37, Ramat Gan: Bar Ilan University Press, p. 7- 22, 1994.

MARGULIN, Bruria. Hamikud Hatachbiri Keeven Bochan Signonit Basiporet Haivrit Uvasiporet Hapalestinit Bnot Zmanenu (O enfoque sintático na literatura hebraica e palestina modernas), Ramat Gan: Universidad de Bar Ilan Press, 1996.

Al Hatopicalizatzia basiporet Haivrit Bat Zmanenu (Sobre a topicalização na literatura hebraica contemporânea). In Helkat Lashón, n. 29- 32, Jerusalén: Akademón Press, p. 58- 72, 2000. 
ORNÁN, Uzi. Hayichud, Torat Haguilgulim Umishpat Hayichud (A extraposição, teoría das transformações e a extraposição). In Hamishpat hapashut, Jerusalén: Akademón Press, p. 102- 116, 1989.

ORON, Yocheved. Mishpetei Yichud BaMishná (A extraposição na Mishná). Ramat Gan: Universitat Bar Ilan Press, 1986.

PELED, Yishai, Tachbir Haivrit Haktuvá: Ebetim Teoretiim Veisumim. (Sintaxe do hebraico escrito: aspectos teóricos e aplicáveis), Tel Aviv: Universidad de Tel Aviv Press, 1998.

PERETZ, Ytzchak, Mishpat HaZiká BaIvrit Lechol HaTkufot (Orações sibordinadas em hebraico em todos seus períodos), Tel Aviv: Dvir Press, 1967.

RABID, Dorit. Mispar Ebetim shel beayiat seder hamarkivim beivrit isreelit modernit (Alguns aspectos sobre o problema da ordem dos componentes no hebraico israelense moderno). In Balshanut Ivrit Chofshit, n. 11, Ramat Gan: Universitat Bar Ilan Press, p. 1- 45, 1977.

RACHAMIM, Dalia. Lashon Acheret: Lashon Beeksher Tekstuali (Otra língua: a língua em outro contexto), Even Yehudá: Reches Press, 1999.

ROZEN, Chaim. Ivrit Tová, Iunim Betachbir (Bom hebraico, estudos em sintaxe), Jerusalem: Hasefer Press, 1969.

HaEntziklopedia HaIvrit (A Enciclopedia Hebreaica), Jerusalén:

Entziklopediot Press, 1955- 1958.

ROZENTAL, Rubik. Hashpaat Iotzei Tzfon África al Halexicon Haisraelí (Influência dos migrantes do Norte da África sobre o léxico israelense), In Hed HaUlpán 
Hechadash, n. 96, Jerusalem: Ministério de Educalção israelense Press, p. 67- 72, 2010.

RUBINSTEIN, Eliezer. Ha Mishpat Hasheimani, Iunim Betachbir Yameinu (A oração sustantiva, estudos em sintaxe moderna), Tel Aviv: Hakibutz Hameuchad Press, 1969.

SCHWARTZVALD, Ora, Gonei Lashón Baivrit Bat Zmanenu (As máscaras do hebraico contemporâneo). In Teuda Medabrim Ivrit, n. 18, Tel Aviv: Univesidade de Tel Aviv Press, p. 141- 175, 2001.

Leshelat Tkinutam Veivatzrutam shel Mishpetei Yichud Beivrit (Sobre a pergunta e a criação das orações em hebraico). In Bar Ilan, n. 13, Ramat Gan: Bar Ilan University Press, p. 321- 340, 1971.

SHTIL, Nimrod. Haaravim BeIsrael: Hashpaat Leshonit Vedarchei Rechishat Haivrit (Os árabes em Israel: Influência linguística e a forma de adquirir o hebreaico), In Hed HaUlpán Hechadash, n. 93, Jerusalem: Ministério de Educação israelense Press, p. 70- 88, 2008.

SEGAL, Tzvi, Dikduk Leshón HaMishná (Gramática do hebraico da Mishná), Tel Aviv: Dvir Press, 1935.

SHARON, Yehudit. Mishpat Yichud: Madrich Lamoré (Oração extraposta: Guia para o professor). Ramat Gan: Universidad Bar Ilan Press, 1995.

SHLEZINGER, Yitzchak, Kotviut beramot lashón batexstim sifrutiim (Polaridade nos níveis lingüísticos dos textos literários). In Teudá 18 Medabrim Ivrit, Tel Aviv: Univesidade Tel Aviv Press, p. 375- 394, 2001. 
SHTIL, Nimrod, Digmei Hamishpat Baivrit Hameduberet (Tipos de orações no hebraico oral). Tel Aviv: Chamul Press, 1994.

SMOOHA, Samy. Shesaim Maamadiim, Edatiim Veleumim Ve Democratia Beisarel (Brechas de classe, étnicas e nacionais e democracia em Israel). In Hachevrá Haisraelit: Ebetim Bikortiim, p. 172- 202 (A Sociedade Israelense: Tópicos críticos), Uri Ram organizador, Tel Aviv: Breirot press, 1993.

SOMEK, Roni. Machteret Hechalav (A resistência do Leite), Hor Yehudá, Zmurá Bitán Press, 2005.

TRUMER, Pniná. Tezuzot Kategorialiot Baivrit Haisreelit- Kavim Klaliim Lemehkar (Mudanças nas categorías do hebraico israelense- Linhas gerais para pesquisa). In Helkat Lashón, n. 29- 32, Tel Aviv: Tel Aviv University Press, p. 222- 241, 2000.

TZDAKA, Ytzchak. Mishpat Yichud Hanosé VeHakinui Hu (A oração extraposta sujeito e o pronome ele). In Leshonenu, n. 44, Jerusalén, Academia de la Lengua Hebrea Press, p. 239- 224, 1979.

Tachbir Haivrit Beyameinu (Sintaxe hebraica dos nossos días)), Jerusalem: Kiryat Sefer Press, , 1981.

Tachbir Hamishpat Leor Hateoriot Hachadashot (Sintaxe da oração segundo as novas teorias). Jerusalén: Akademón Press, 1978.

TZUKERMAN, Guilad. Israelit Safá Yafa?: Az Eizo Safá Haisreelim Medabrim? (Israelense língua bonita?: Então que língua falam os israelenses?) Tel Aviv: Am Oved Press, 2008. 
WERTHEIMER, Ada. Al Psukit Hanasú Habilti Meshuavedet (Sobre a proposição subordinada predicativa). In Leshonenu, n. 60, Jerusalén: Academia de la Lengua Hebrea Press, p. 339- 342, 2001.

\section{Em outros idiomas}

ANDERSON, Stephen. On the Role of Deep Structure in Semantic Interpretation. In Foundations of Language, n. 6, Oxford: Oxford University Press, p. 197- 219, 1971.

BADAWI, Elsaid. Modern Written Arabic: A Comprehensive Grammar, United Kingdom: Routledge Press, 2004.

BALLY, Charles. Linguistique générale et linguistique française, París: Leroux Press, 1932.

BERMAN, Ruth. Modern Hebrew, in The Semitic Languages, London: Routledge Press, p. 312-333, 1997.

BOLOZKY, Shmuel. Word Formation Strategies in Hebrew Verb System: Denominative Verbs, in Afroasiatic Linguistics, n. 5, Malibu, California, Undena Publications, p.111- 136, 1978

BROCKELMANN, Carl. Hebräische Syntax. Neukirchener Verlag: NeukirchenVluyn, 2004.

BUSSMANN, Hadumod. Routledge Dictionary of Language and Linguistics, London \& New York: Routledge Press, 1996. 
CIFUENTES HONRUBIA, José Luis. Lengua y espacio. Introducción al problema de la deíxis en español, Alicante: Universidad de Alicante Press, 1989.

COHEN, Erik. The Black Panthers and Israeli Society. In The Jewish Journal of Sociology 14, n. 1, London, p. 93- 109, 1972.

COMBETTES BERNARD, Les constructions détachées en français. Paris: Editions Ophrys, 1998.

DAPENA, PORTO, Álvaro. Los Pronombres. Madrid: SGEL, 1986.

DRIVER, Samuel Rolles. The Casus Pendens, A Treatise on the Use of the Tenses in Hebrew and Some Other Syntactical Questions, Oxford: Clarendon Press, 1998 [1892].

TERRA, Ernani. Curso Prático de Gramática, São Paulo: Editora Scipione, 2008.

EZRAHI, Yaron. Rubber Bullets: Power and Conscience in Modern Israel. New York: Farrar: Straus and Giroux, 1996.

GARELLI, Marta; IGLESIAS, Nélida; DEL RÍO, Hevel. El verbo latino possum: valores semánticos, In Praesentia, n. 7, Mérida: Venezuela, Universidad de los Andes Press, 2006. Disponível em http://vereda.saber.ula.ve/sol/praesentia7/possum.htm.

GESENIUS, Wilhelm. Hebrew Grammar, Edited and Enlarged by E. Kautzch, Second English Edition, Revised in Accordance with the Twenty- Eighth German Edition by A. E. Cowley, 1909.

GIVON, Talmy. Topic, Pronoun And Grammatical Agreement, In Subject and Topic, p. 88- 149. New York: Academic Press, 1976 
GLINERT, Lewis. The Grammar of Modern Hebrew, Cambridge: Cambridge, 1989.

GOLDENBERG, Gideon. Tautological Infinitive, In Israel Oriental Studies, n. 1, Tel Aviv: Tel Aviv University Press, p. 36- 81, 1971.

On Syriac Sentence-Structure, In Arameans, Aramaic and the Aramaic Literary Tradition, Ramat Gan: Universidade de Bar Ilan Press, 1983.

HAIMAN, John, Conditionals are Topics, Language, n. 54, Baltimore: Waverly Press, p. 564- 589, 1978

HALLIDAY, Michael and HASAN, Ruqaiya. Cohesion in English. London: Longman, 1976.

HAYON, Yehiel. Having and Being in Modern Hebrew. In Hebrew Computational Linguistics, n. 5, Jerusalén: Academon Press, p. 10- 23, 1972.

JESPERSEN, Otto. Analytic Syntax, USA: University Of Chicago Press, 1984.

A Modern English Grammar on Historical Principles, III, London \& Copenhagen: Unwin Hyman Press, 1954.

The Philosophy of Grammar, USA: University Of Chicago

Press, 1992.

LE BIDOIS, Georges e Robert. Syntaxe du français moderne, París: Picard Press, 1971. 
LEHMANN, David e SIEBZEHNER, Batia. Remaking Israeli Judaism: The

Challenge of Shas, Oxford: Oxford University Press, 2006.

LYONS, John. Introduction to Theoretical Linguistics, Cambridge: Cambridge University Press, 1968.

MOSCOSO GARCÍA, Francisco. Situación lingüística en Marruecos: árabe marroquí, beréber, árabe estándar, lenguas europeas, In Al-Andalus-Magreb, n. 10, Cadiz: Universidad de Cádiz Press, p. 167-186, 2002-2003. Disponível em http://www.arabemarroqui.es/Recursos/Situacion\%20linguistica\%20Marruecos.pdf

NADASDI, Terry. Subject NP Doubling, Matching, and Minority French, In Language Variation and Change, n. 7, Cambridge: Cambridge University Press, 1995 , p. 1- 14.

PADILlA GARCÍA, Xosé. El orden de las Palabras en el Español Coloquial (Dissertação doutoral), Universitat de Valencia, 2001.

PEREZ BELLO, Gloria. Uso de las dislocaciones a la derecha y a la izquierda en castellano e italiano, In Interlingüística, n. 9, Universidad Complutense de Madrid, 1998, p. 253- 260.

ROZENCHAN, Nancy. Representação do marroquino na literatura hebraica contemporânea. In Arquivo Maaravi (UFMG), v. 1, n. 6, Minas Gerais: Universidade Federal de Minas Gerais, p. 20-30, 2010.

SAID, Edward. Orientalismo: o Oriente como invenção do Ocidente. São Paulo: Companhia das Letras, 2003.

SÁNCHEZ, Pablo. Marruecos tras la conquista islámica: un estudio de geografía dialectal, In Estudios de dialectología norteafricana y andalusí, n. 11, Zaragoza: IEIOP Press, p. 101- 119, 2007. 
SEARLE, John. Indirect Speech Acts, In Syntax and Semantics, n. 3, Cambridge: Cambridge University Press, p. 59-82, 1975.

SEGEV, Tom. The First Israelis. Universidade de Michigan: edição digital, 2008.

TOPEL, Marta. Uma Tradição milenar, uma ciência moderna. A Antropologia Israelense: Autores e leitores. Tese de doutorado defendida no Departamento de ciências sócias da Unicamp, 1996.

WEINGROD, Alex. The Two Israels. In Commentary, n. 33, New York: The American Jewish Committee Press, p. 313- 319, 1962.

\section{II- Livros do corpus principal (Todos em hebraico)}

GROSSMAN, David, Yesh Yeladim Zig- Zag (Há crianças Zig- Zag), Tel Aviv: HaKibutz HaMeuchad Press, 1994.

LINOR, Irit, Shtei Shilguiot (Duas Brancas de Neve), Or Yehuda: Amora Press, 1993.

MENDELSON, Tuvia, Guever Garush (Homem Separado), Jerusalén: Keter Press, 1993.

OZ, Amós, Al Taguidi Layla (Não Digas Noite), Jerusalén: Keter Press, 1994.

Kufsá Shchorá (Caixa Preta), Tel Aviv: Am Oved Press, 1987. 
SHACHAR, David, Chalom Leil Tamuz (Sonho de uma noite de Tamuz), Sifriat Hashaot Press: Jerusalem, 1996.

SHALEV, Meir, Keyamim Achadim (Como alguns dias), Tel Aviv: Am Oved Press, 1994.

\section{III- Livros de consulta}

MELMAN, Yosi, Shutfut Oienet, Haksharim Hasodiim Bein Israel Leyarden (Parceria Hostil, contatos secretos entre Israel e a Jordânia), Tel Aviv: Meitam Press, 1987.

SIVÁN, Emanuel, Mitosim Politiim Araviim (Mitos Políticos Árabes), Tel Aviv: Am Oved Press, 1988.

SUSSER, Asher, Bein Yarden LePalestin, Biografia Politit shel Wasfi al-Tal (Entre a Jordânia e a Palestina, Biografia política de Wasfi Al-Ta), Tel Aviv: HaKibutz Hameuchad Press, 1994.

SHIF, Zehev, YA'ARI, Ehud, Intifada, Tel Aviv: Yedihot Hacharonot Press, 1990.

\section{IV- Imprensa}

Haaretz e Yedihot Hacharonot da época de agosto 2004 até janeiro 2005.

\section{V- Linguagem oral}

Linguagem oral segundo foi informada através da literatura escrita quando os temas derivam do contexto. 
Comentarios dos entrevistados e entrevistadores na rádio e televisão, frases ditas só em discursos espontáneos.

Discurso espontáneo frente ao público. 